
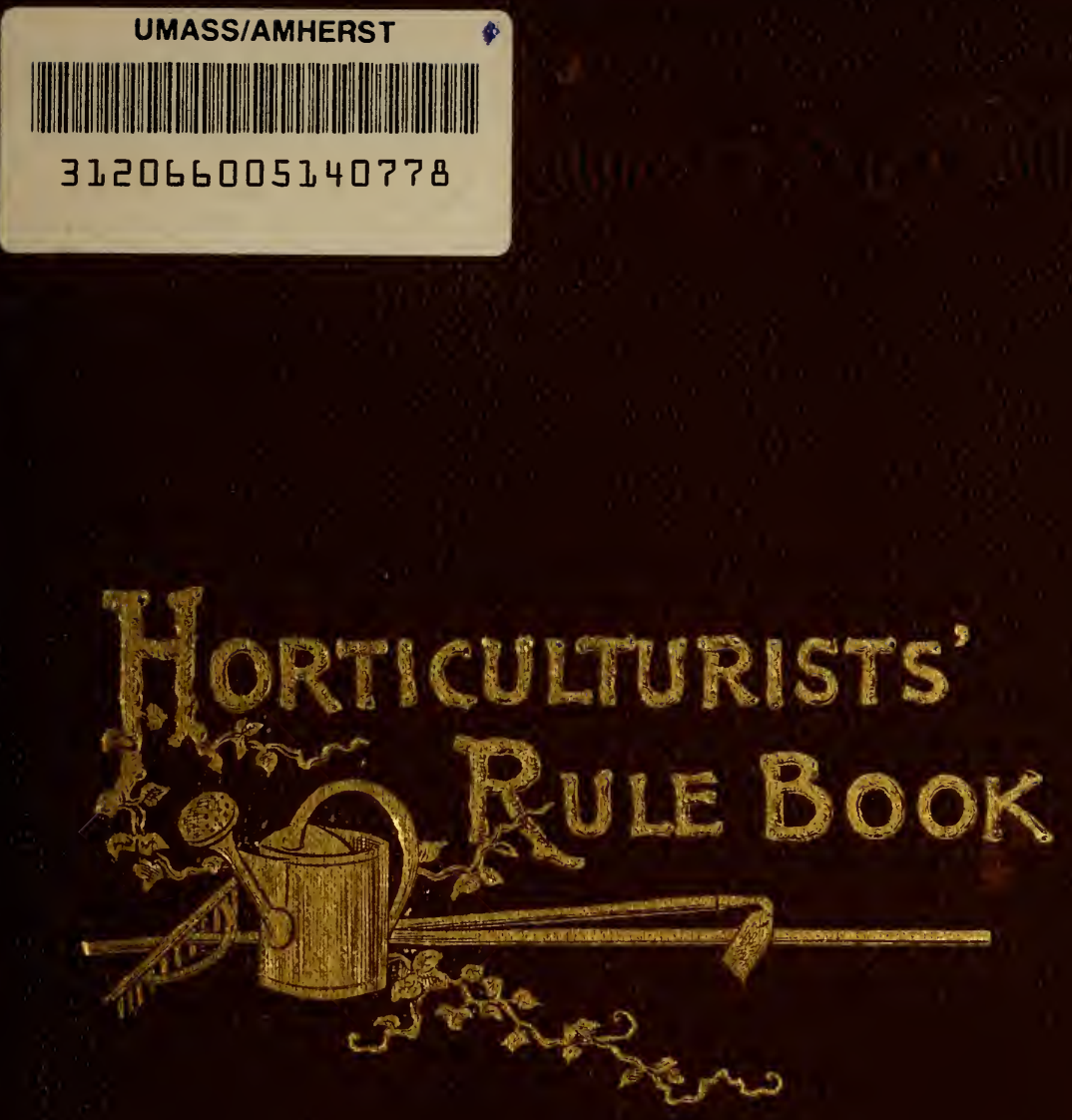


\section{MASSACHUSETTS STATE COLLEGE}

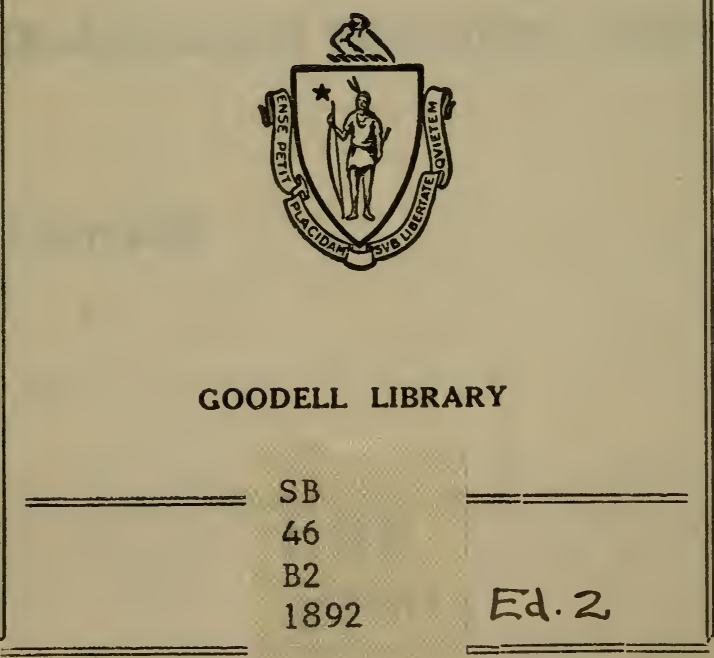


This book may be kept out

\section{TWO WEEKS}

only, and is subject to a fine of TWO

CENTS a day thereafter. It will be due on the day indicated below. 





\title{
The Horticulturist's
}

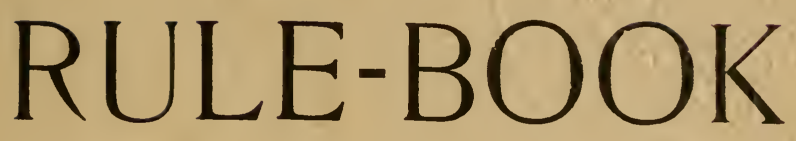

A Compendium of Useful Information for

FrUIT-GROWERS, TRUCK-GARDENERS, FlORISTS AND OTHERS.

Completed to the Beginning of the Year

\author{
1892 \\ BY L. H. BAILEY \\ SECOND EDITION, REVISED
}

NEW YORK

THE RURAL PUBLISHING COMPANY TIMES BUILDING ${ }^{\circ}$ 


\section{0 \\ B15h. Fd. z}

\section{BY THE SAME AUTHOR.}

I. ANNALS OF HORTICULTURE IN NORTH AMERICA FOR THE YEAR 1889. A Witness of Passing Events and a Record of Progress. Pp. 204. Illustrated. Cloth, \$1 ; paper, 60 cents.

II. Volume for 1890 . Pp. 312. Illustrated. Same Price.

III. Volume for I891. Pp. 415. Illustrated. Same Price.

THE HORTICULTURIST'S RULE-BOOK. A Compendium of Useful Information for Fruit Growers, Truck Gardeners, Florists and Others. New Edition. Pp. 22I. Cloth, \$I; paper, 50 cents.

THE NURSERY BOOK. A Complete Guide to the Multiplication and Pollination of Plants. Pp. 304. I06 Illustrations. Cloth, \$1; paper, 50 cents.

CROSS-BREEDING AND HYBRIDIZING. The Philosophy of the Crossing of Plants, Considered with Reference to their Improvement under Cultivaticn. With a Bibliography of the Subject. Pp. 48 . Paper $25 \mathrm{cts}$.

FIFID-NOTES ON APPLE-CULTURE. Pp. 90 ; rg Illustrations. Cloth, 75 cents.

TALKS A-FIELD: ABOUT PLANTS AND THE SCIENCE OF PLANTS. Pp. 173; 100 Illustrations. Cloth, *1.

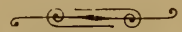

THE RURAL PUBLISHING COMPANY, TIMES BUILDING, NEW YORK. 
The author wishes to be advised of any errors in this work, and he desires any information which will be useful in the preparation of a third edition. IтHACA, N. Y., Dec. 31, 1892. 


\section{CONTENTS.}

CHAPTER I.

INSECTICIDES. . . . . . . . . . . . $7-17$

CHAPTER II.

Injurious Insects, with Remedies and Preventives. 18- 39

CHAPTER III.

Fungicides, for Plant Diseases. . . . . . . . . . 40- 44

CHAPTER IV.

Plant Diseases, with Preventives and Remedies . . 45- 60

CHAPTER V.

InjUries from Mice, Rabbits, SQUirrels aNd Birds, with Preventives and Remedies . . . . . . 61- 64

CHAPTER VI.

WEEDS AND Moss. ........... 65-67

1. Weeds in General . . . . . . . . . 65

2. Weeds in Lawns . . . . . . . . . . . . 65

3. Weeds on Walks . . . . . . . . . . . . . 66

4. Moss on'Walks and Lawns. . . . . . . . . . 67

5. Moss on Trees.............. . 67

CHAPTER VII.

WAXES For GRAFTiNa AND FOR WoUNDS...... 68- 70

1. Common Resin and Beeswax Waxes . . . . . . . 68

2. Alcoholic Waxes .............. . 68

3. French and Pitch Waxes. . . . . . . . . . 69

4. Waxed String and Bandage . . . . . . . . 69

5. Waxes for Wounds. . . . . . . . . . 70

(2) 
CHAPTER VIII.

Cements, Mortars, Paints and Glues. . . . . . 71 - $\pi$

1. Cement and Mortar ............ 71

2. Concrete, etc., for Floors, Borders and Walks . . 73

3. Paints and Protective Compounds ........ 74

4. Glues ................ 76

CHAPTER IX.

Seed-Tables ..................... $78-86$

1. Quantity of Seed Required to Sow an Acre ... 78

2. Weight and Size of Garden Seeds ....... 79

3. Number of Tree-Seeds in a Pound . . . . . . . . 82

4. Longevity of Garden Seeds . . . . . . . . . 83

5. Average Time Required for Garden Seeds to Germinate............. 86

6. Proper Kinds and Quantities of Seeds for a Model English Kitchen-Garden of $1 \frac{1}{4}$ acres . .

CHAPTER X. .

Planting-Tables ............... 87- 96

1. Dates for Sowing or Setting Kitchen-Garden Vegetables in Different Latitudes...... 87

2. Tender and Hardy Vegetables .......... 90

3. Usual Distances Apart for Planting Fruits ... . 90

4. Usual Distances Apart for Planting Vegetables . 91

5. Number of Plants Required to Set an Acre of

Ground at Given Distances . . . . . . .

\section{CHAPTER XI.}

Maturities, Yields and Multiplication . . . . . 97-103

1. Time Required for Maturity of Different Garden Crops, Reckoned from the Sowing of the Seed.

2. Time Required, from Setting, for Fruit Plants to Bear ...............

3. Average Profitable Longevity of Fruit Plants Under High Culture........... 
Chapter XI., continued.

4. Average Yields per Acre of Various Crops.... .

5. Tabular Statement of the Ways in which Plants are Propagated . . . . . . . . . 100

6. Ways of Grafting and Budding . . . . . . . 101

7. Particular Methods by which Various Fruits are Multiplied .............. . . . 102

8. Stocks Used for Various Fruits . . . . . . . 103

CHAPTER XII.

Methods of Keeping and Storing Froits and Vege-

TABLES. . . . . . . . . . . . 104-112

\section{CHAPTER XIII.}

Standard and Legal Measures and Sizes . . . . . 113-122

1. Standard Flower-Pots . . . . . . . . . . . 113

2. Legal and Standard Measures . . . . . . . . 114

3. Miscellaneous Legal Weights per Bushel . . . . 116

4. Miscellaneous Legal Sizes . . . . . . . . . . . 116

5. Society and Customary Standards . . . . . . 117

6. Covent Garden Measures . . . . . . . . . . 121

\section{CHAPTER XIV.}

Tables of Measures and Weights . . . . . . 123-128

\section{CHAPTER XV.}

Miscellaneous Tables, Figures and Notes. . . . . 129-140

1. Quantity of Water Held by Pipes of Various Sizes. . . . . . . . . . . . 129

2. Number of Gallons in Circular Tanks and Wells. 129

3. Number of Gallons in Square-built Tanks . . . . 130

4. Thermometer Scales... . . . . . . . 131

5. Effects of Wind in Cooling Glass. . . . . . . . 131

6. Per Cent. of Rays of Light Reflected from Glass

Roofs at Various Angles of Inclination. . . . 
Chapter XV., continued.

7. Area of Glass Used for Commercial Greenhouse

Purposes in Various States and Provinces. . .

8. National and Party Flowers . . . . . . . . . 133

9. Dates at which Various Fruits and Nuts appear in Northern Markets. . . . . . . . . . 134

10. What Constitutes Wholesale Quantities . . . . 135

11. Average Prices in France of Various Orchid Flowers ............... 136

12. Weights of Various Varieties of Apples per Bushel. ................ 136

13. Various Recipes and Rules. . . . . . . . . 137

14. Various Figures . . . . . . . . . . . . . 139

CHAPTER XVI.

RULES . . . . . . . . . . . . . . . . . 141-149

1. Loudon's Rules of Horticulture . . . . . . . . 141

2. Rules of Nomenclature. . . . . . . . . . . . 141

3. Rules for Exhibition . . . . . . . . . . . . . 143

CHAPTER XVII.

Postal Rates and Regulations. . . . . . . . . . 150-154

1. Classes of Domestic Mail Matter and Rates . . . 150

2. Foreign Postage... . . . . . . . . 152

3. Unmailable Matter. . . . . . . . . . . . . . 153

\section{CHAPTER XVIII.}

Weather Signs and Protection from Frost . . . . 155-157

\section{CHAPTER AIX.}

Collecting and Preserving . . . . . . . . . 158-166

1. Collecting and Preserving Plants ... . . . 158

2. Preserving and Printing of Flowers and Other Parts of Plants . . . . . . . . . 150

3. Perfumery ............... . . . . 164

4. Collecting and Preserving Insects ....... 165 


\section{CHAPTER XX.}

Elements, Symbols and Analyses. . . . . . . 167-184

1. The Elements and their Symbols, and the Composition of Various Substances. . . . . . . 167

2. Analyses ................. . . 168

(a) General Analyses of Fruits and Fruit-Plants . I68

(b) Analyses of Fruits and Garden Products, with Reference to their Fertilizing Constituents . . I72

(c) Analyses of Animal Excrements . . . . I76

(d) Analyses of Various Materials which are Used for Fertilizers . . . . . . . . . . I79

(e) Trade Values for I8gI of Fertilizing Ingredients in Raw Materials and Chemicals . . . I 183

\section{CHAPTER XXI.}

Names, Histories and Statistics . . . . . . . . 185-199

1. Vegetables which have Different Names in England and America . . . . . . . . . . 185

2. Names of Vegetables in Various Languages . . . 186

3. Derivation of the Names of Various Fruits and Vegetables............... 190

4. Periods of Cultivation and Native Countries of Cultivated Plants . . . . . . . . . 192

5. Statistics of the Vegetable Kingdom . . . . . . 194 


\section{CHAPTER I.}

\section{INSECTICIDES.}

The results obtained from the use of any insecticide or fungicide depend upon the operator. Timeliness, thoroughness and per. sistence are the watchwords of success. It is easier to keep an enemy away than to drive him away. The worst foes are often the smallest ones, and the injury is often done before they are detected. Be ready and begin early.

Arsenic.-Known to chemists as arsenious acid or white oxide of arsenic. It is considered an unsafe insecticide, as its color allows it to be mistaken for other substances; but in its various compounds it forms our best insecticides. From 1 to 2 grains usually prove fatal to an adult; 30 grains will usually kill a horse, 10 a cow and 1 grain or less is usually fatal to a dog. In case of poisoning, while awaiting the arrival of a physician, give emetics, and after free romiting, give milk and eggs. Sugar and magnesia in milk is useful.

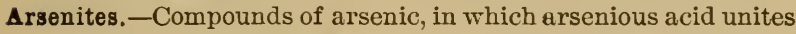
with some metallic base. The leading arsenites used in destroying insects are Paris green and London purple:

PARIS GREen.-An aceto-arsenite of copper. When pure, it contains about 58 per cent. of arsenic, but the commercial article usually contains less, often as little as 30 per cent. The following may be considered an average analysis: Arsenic, 47.68 per cent. ; copper oxide, 27.47; sulphuric acid, 7.16; moisture, 1.35 ; insoluble residue, 2.34 . It is applied in either a wet or dry condition, but in any case it must be much diluted. For making a dry mixture, plaster, flour, air-slaked lime, road dust, or sifted wood-ashes may be used. The strength of the mixture required depends upon the plants and insects to which it is to be applied. The strongest 
Arsenites (Paris green), continued.

mixture now recommended is 1 part of poison to 50 of the diluent, but if the mixing is very thoroughly done, 1 part to 100 or even 200 is sufficient.

Paris greeu is practically insoluble in water. When mixed with water, the mixture must be kept in a constant state of agitation, else the poison will settle and the liquid from the bottom of the cask will be so strong as to do serious damage, while that from the top will be useless. For potatoes, apple trees and most species of shade-trees, 1 pound of poison to 200 gallons of water is a good mixture, For the stone-fruits, 1 pound to 300 or even 350 gallons of water is a strong enough mixture. Peach trees are very apt to be injured by arsenites, and for them the mixture should be no stronger than 1 pound to 300 gallons. In all cases, the liquid should be applied with force in a very fine spray. At some seasons of the year foliage is more liable to injury than at others.

LoxDON PCRPLE. An arsenite of lime, obtained as a by-product in the manufacture of aniline dyes. The composition is variable. The amount of arsenic varies from 30 to over 50 per cent. The two following analyses show its composition : 1. Arsenic, 43.65 per cent.; rose aniline, 12.46 ; lime, 21.82 ; insoluble residue, 14.57 ; iron oxide. 1.16 ; and water, 2.27 . 2. Arsenic, 55.35 per cent.; lime, 26.23; sulphuric acid, .22; carbonic acid, .27; moisture, 5.29. It is a finer powder than Paris green, and therefore remains longer in suspension in water. It is used in the same manner as Paris green, but is sometimes found to be more caustic on foliage. This injury is due to the presence of much soluble arsenic. London purple should not be used on peach trees.

Combinations of ARSEximes AND FUNGICIDES. The arsenites may be used in connection with some fungicides, and both insects and plant-diseases in this manner may be combated at the same time. An ounce of the arsenites may be added to ten gallons of Bordeaux mixture for potatoes, and other combinations will occur to the operator. The arsenites are also sometimes added to soap and other washes.

The addition of lime to Paris green and London purple mixtures greatly lessens injury to foliage, and, as a consequence, they can be applied several times stronger than ordi- 


\section{Insecticides.}

Arsenites and fungicides, continued.

narily used when they are combined with the Bordeaux mixture. The free lime in the mixture combines with the soluble arsenic, which is the material that injures the foliage, and the combination is thus made quite harmless.

London purple and Paris green should rarely be applied with the ammoniacal carbonate of copper, as the ammonia in the latter dissolves the arsenic, making the combination caustic. The addition of sulphate of copper to the arsenites also increases injury.

Bait. -1. Paris green or London purple, 1 ounce, chopped grass or leaves, 8 ounces, and enough syrup to allow the mass to be worked into balls. For wire-worm beetles, crickets, katydids, etc.

2. Bran 40 pounds, middlings 15 pounds, arsenic 20 pounds, cheap syrup 2 gallons. Mix in soft water to a paste. For grasshoppers.

Bisulphide of carbon.-A thin liquid which volatilizes at a very low temperature, the vapor being very destructive to animal life. It is exceedingly inflammable, and should never be used near a lamp or fire. It is used for many root-insects. It is poured into a hole which is immediately closed up, causing the fumes to permeate the soil in all directions. In loose soils it is very destructive to insects. It is also inserted in tight receptacles to kill such insects as pea-weevil and museum pests.

Bisulphide of carbon and kerosene.-1 part of bisulphide of carbon mixed with from 5 to 20 parts of kerosene will produce vapor sufficient to kill many grain-eating insects.

Blue vitriol or copperas. -1 ounce of copperas to a pail of water is sometimes effective in destroying root-insects.

Coal-tar fumes.-Burn rags coated with coal-tar attached to a pole. Remedy for aphis.

Carbolic acid and soap mixture,-1 pint crude carbolic acid, 1 quart soft soap, 2 gallons hot water. Mix thoroughly. This wash is used for borers, and for plant-lice. Apply with a cloth or soft broom.

Carbolic acid and water.-Add 1 part of acid to from 50 to 100 parts of water. For root-insects. 
Carbolized plaster.-Stir 1 pint of crude carbolic acid into $\mathbf{5 0}$ pounds of land-plaster. Or, quick lime may be slaked with the acid. The powder is thrown over the tree when the dew is on, as a remedy for the curculio. It should be applied profusely.

Glue and arsenites wash.-Common glue, 1 pound, soaked a few hours in cold water and then dissolved in $1 / 2$ gallon of hot water; add 1 ounce London purple or Paris green, stir well, and add hot water till the mixture measures 2 gallons. For preventing the attacks of borers.

Hot water.-Submerge affected plants or branches in water at a temperature of about $125^{\circ}$. For aphis.

Kerosene.-In pure state, kerosene is used as an insecticide upon many plants, with various results. It does not appear to injure the coleus, rose, grape, peach and pea, but does injure the potato, tomato and gooseberry, and other plants.

Kerosene emulsion.-1. Soft soap, 1 quart, or hard soap-preferabiy whale-oil soap-1/4 pound; 2 quarts hot water; 1 pint kerosene. Stir until all are permanently mixed, and then dilute with water to one-half or one-third strength. A good way to make the emulsion permanent is to pump the mixture back into the receptacle several times. Makes a permanent emulsion with either hard or soft water.

2. Hard soap, $1 / 4$ pound; boiling water, 1 gallon; kerosene, 2 gallons. Churn or pump the ingredients vigorously 15 or 20 minutes. Dilute ten times when using. This is the Hubbard or standard emulsion for scale of the orange.

2 ounces balsam of fir added to the above appears to increase its efficiency, and it causes it to adhere to foliage better. $1 / 2$ pint spirits of turpentine is sometimes added.

3. Pyrethro-kerosene emulsion. In the place of pure kerosene in the above emulsions, use a kerosene decoction of pyrethrum, made by filtering 1 gallon of kerosene through $21 / 2$ pounds of pyrethrum. Valuable.

Kerosene and milk emulsion.-Sour milk, 1 gallon; kerosene oil, 2 gallons; warm to a blood heat and mix thoroughly. Dilute 10 times with water. For scale insects and plant-lice.

Kerosene and condensed milk emulsion.-Kerosene, 2 gallons, or 64 per cent. of the entire mixture; condensed milk, 4 cans of $8 / 4$ pint, or $121 / 2$ per cent.; water twice the quantity of milk, or 25 per cent. 
Kerosene and water emulsion.-Goff atomizes kerosene and water as follows: To the Woodason atomizing bellows a small cup is attached directly in front of the fount for holding the liquid to be atomized. From this cup a very slender copper tube is passed through the side of the fount where it enteres the larger tube that conducts the liquid from the fount to the mouth of the bellows. It then curves upward, passing through the center of this tube as far as the mouth of the bellows, where both come to an end at the same point. Kerosene is then placed in the added cup and water in the fount. On working the bellows the liquids are atomized together. The proportion of kerosene emitted will depend upon the relative diameters of the two tubes, but it may also be regulated by the relative depths of the liquid in their respectire founts. A better way would be to use but a single fount and to divide this into two parts, one for kerosene and the other for water. This would permit the mouth of the bellows to be brought nearer to the plant to be atomized.

Lime spray.-Slake $1 / 2$ peck or a peck of lime in a barrel of water, straining the lime as it enters the barrel to prevent its clogging the pump. Apply in a spray until the tree appears as if whitewashed. For rose-chafer.

London purple.-See Arsenites.

Lye wash. -1 pound concentrated lye, or potash $11 / 4$ pounds, to 3 gallons water. On an arerage, 1 bushel of good woodashes contains about 4 pounds of potash. For scale insec ss.

Common home-made lye is often diluted with water and applied to apple branches with a brush as a remedy for the bark-louse. It is also recommended as a remedy for the cabbage-worm, being sprinkled on the cabbages with a watering pot. If concentrated lye is used, a pound should be diluted with a barrel of water.

Lye and sulphur wash.-Concentrated lye, 1 pound, or potash, $11 / 4$ pounds; sulphur, $1 \frac{1}{2}$ pounds; water, 3 gallons. For scale insects.

Lye and whale-oil soap wash.-(a.) Dissolve 1 pound of concentrated lye in one gallon of water; add to this $1 \frac{1}{2}$ pounds of sulphur and boil until sulphur is dissolved. (b.) Dissolve 14 pounds of the best whale-oil soap in 54 gallons of water; add solution $a$ to $b$ and boil for a short time. For scale; 
Lye and whale-oil soap wash, continued.

used as a summer wash when the first brood is hatching. Use at $130^{\circ}$ Fahrenheit, thoroughly washing the trunks and larger branches and spraying the smaller branches and twigs.

0il and alkali wash.-1. 11/4 gallons of whale-oil, 25 pounds salsoda; dissolve the sal-soda in 25 gallons of water and heat it to boiling. When boiling pour the whale-oil in. Apply the wash when cooled to $130^{\circ} \mathrm{Fahr}$.

2. 1 pound of concentrated lye (American) of $\$ 0$ per cent. ; or 4-5 of a pound of Greenbank powdered caustic soda, of 98 per cent.; or 1 pound of solid caustic soda, of 76 per cent.; or $1 \frac{1}{2}$ pounds of solid caustic soda of 63 per cent. These varying proportions are given because the caustic sodas in the markets are of different strengths and purity. Whichever one is chosen, add to each amount named $1 / 2$ pound of commercial potash and dissolve in 6 gallons of water.

Both washes are for scale insects on deciduous trees in winter. (Californian.)

Paraffine oil. When plants are infested with lice, wet them at intervals of three or four days for about three weeks with diluted paraffine in the proportion of a wineglassful to watering-can of water.

Paris green.-See Arsenites.

Plaster and kerosene.-2 quarts of plaster or wood-ashes, 1 tablespoonful of kerosene. Mix and rub with the hands until the oil is well incorporated. Bone-flour may be substituted for the plaster. Repellent.

Potash.-Kainit, 1 ounce to a pint of water, applied in a spray, is recommended for aphis and various leaf-eating larvæ. Muriate of potash, applied in the same strength, is as good, but is more likely to injure the plants.

Promoting growth.-Any course that tends to promote vigor will be helpful in enabling plants to withstand the attacks of plant-lice and other insects.

Pyrethrum.-A very fine and light brown powder made from the flower-heads of species of pyrethrum. It is scarcely injurious to man. Three brands are upon the market: 
Pyrethrum, continued.

Persian insect-Powder, made from the heads of Pyrethrum roseum, a species now cultivated as an ornamental plant. The plant is native to the Caucasus region.

DaLMaTION INSECT-POWDER, made from Pyrethrum cineraricefolium.

BUHACH, made in California from cultivated plants of $P$. cinercricefolium.

When fresh and pure, all these brands appear to be equally valuable, but the home-grown product is usually considered most reliable. Pyrethrum soon loses its value when exposed to the air. It is used in various ways:

1. In solution in water, I ounce to 3 gallons.

2. Dry, without dilution.

3. Dry, diluted with flour or any light and fine powder. The poison may be used in the proportion of 1 part to from 6 to 30 of the diluent.

4. In fumigation. It may be scattered directly upon coals, or made into small balls by wetting and molding with the hands and then set upon coals. This is a desirable way of dealing with mosquitoes and flies.

5: In alcohol. (1) Put one part of pyrethrum (buhach) and four parts alcohol, by weight, in any tight vessel. Shake occasionally, and after eight days filter. Apply with an atomizer. Excellent for greenhouse pests. For some plants it needs to be diluted a little. (2) Dissolve about 4 ounces of powder in 1 gill of alcohol, and add 12 gallons of water.

6. Decoction. Whole flower-heads are treated to boiling water and the liquid is covered to prevent evaporation. Boiling the liquid destroys its value.

7. Water extract. Pour 2 quarts hot water through about a half pound of pyrethrum, held in a coarse bag, and then add cold water enough to make 2 gallons, and it is well to stir in the powder itself. For aphis and cabbage-worms. It will keep but a few days. Or the extract can be made as follows: Make a paste of 2 tablespoonfuls of pyrethrum by adding water. Stir this into 2 gallons of water and apply with a fine nozzle. This is recommended for the rose-chafer.

8. Pyrethro-kerosene emulsion. See under Kerosene emulsion. 


\section{Pyrethrum (Buhach), continued.}

Good insect-powder can be made from Pyrethrum roseum, and probably also from $P$. cineraricefolium, which is grown in the home garden.

Quassia.-Boil 4 ounces of quassia chips 10 minutes in a gallon of water; strain off the chips and add 4 ounces of soft water, . which should be stirred as it cools. Apply with syringe or brush. Ten or fifteen minutes after it has been applied, give the plant a good syringing with clean water. For plantlice.

Resin soap.-Ingredients for one barrel of 50 gallons: 10 pounds caustic soda, 98 per cent.; 10 pounds potash; 40 pounds tallow; 40 pounds resin. First.-Dissolve the potash and soda in 10 gallons of water. When dissolved, place the whole amount in the barrel to be used. Second.-Dissolve the tallow and resin together. When dissolved, add the same to the potash and soda in the barrel, and stir well for five min. utes or so. Leave standing for about two hours; then fill up with water, stirring well as every bucket of water goes in. Use the following day, 1 pound to the gallon of water. Apply warm. For scale on deciduous trees in summer (Californian.)

Resin and fish-oil soap.-20 pounds of resin, 1 gallon of fish-oil, 8 pounds of caustic soda, and enough water to make 100 gallons. The caustic soda is first dissolved in about 16 gallons of water, after which $1 / 2$ of the solution is taken out and the resin added to that remaining in the kettle. When all the resin is dissolved, the fish-oil is added to it and the whole thoroughly stirred, after which the balance of the caustic soda solution is added very slowly and boiled for about an hour, or until it will readily mix with water. Use an iron kettle. For scale insects on orange and olive. (Californian.)

Resin, soda and tallow soap.-Resin 2 pounds, caustic soda 1 pound, tallow 1 pound. Mix resin and soda, boil about 30 minutes and then add tallow. For use, add 2 gallons water to a pint. Used in spray for scale.

Resin and petroleum soap.-Water, 100 gals. ; resin, $17 \frac{1}{2}$ pounds ; soda (60 per cent.), 7 pounds; fish-oil, 3 pounds; petroleum, 2 pounds. The resin, soda and fish-oil, with 20 gallons water, are boiled together for four hours, when the kerosene is 
Resin and petroleum soap, continued.

added and the whole is thoroughly stirred. While hot, place in a barrel and add the remaining 80 gallons water, and emulsify by thorough stirring. For scale on citrus-trees.

Salt and lime wash. - 25 pounds of lime (unslaked), 20 pounds of sulphur, 15 pounds of salt, 60 gallons of water. To mix the above, take 10 pounds of lime, 20 pounds of sulphur, and 20 gallons of water. Boil until the sulphur is thoroughly dissolved. Take the remainder-15 pounds of lime and 15 pounds of salt-slack-and add enough of water to make the whole 60 gallons. Strain and spray on the trees when milkwarm or somewhat warmer. This can be applied when the foliage is off the tree, and will have no injurious effects whatever on the fruit-buds or the tree itself. For scale on deciduous trees in winter. (Californian.)

Soap and arsenites. - Yellow soap, 4 pounds, which is dissolved in 1 gallon of hot water; add 4 ounces of London purple or Paris green, mix, and dilute with 50 gallons of hot water. For plant-lice.

Soap and lime wash. -5 pounds potash, 5 pounds lard stirred in 5 gallons of boiling water; 1 peck quicklime slaked in $\mathbf{5}$ gallons of boiling water, and mixed while hot with the potash and lard mixture. Dilute by adding 2 gallons of boiling water for each gallon of the mixture. It will keep indefinitely. For preventing the attacks of borers.

Soap and soda wash.-To soft soap add a strong solution of common washing-soda, until the mixture becomes a t'sick paint.

Soap und tobacco.-Dissolve 8 pounds of the best solt soap in 12 gallons of rain-water, and when cold add 1 gallon of strong tobacco liquor. For plant-lice.

Soap, fish-oil.-Good potash lye, 1 pound; fish-oil, 3 pints; soft water, 3 gallons. Dissolve the lye in the water, and when brought to a boil, add the oil. Boil about two hours. When cold, it can be cut into cakes. For use, put the soap in enough hot water to dissolve or cut it, and then 6 to $\$$ gallons water to a pound of soap. For aphis.

soda and aloes.-Dissolve 2 pounds of washing-soda and 1 ounce of bitter Barbadoes aloes, and when cold add 1 gallon of water. Dip the plants into the solution, and lay them on their sides for a short time, and the insects will drop off. 
Soda and aloes, continued.

Syringe the plants with clean, tepid water, and return to the house. For plant-lice.

Soda and resin wash.-Sal-soda, 3 pounds, added to 1 pint of hot water; add slowly 4 pounds of resin, and gradually add 2 pints of hot water. Dilute to 5 gallons. For scale insects; also recommended for curculio.

Soda and whale-oil soap wash.-Dissolve 25 pounds sal-soda in 25 gallons water and heat to boiling, at which time add $11 / 4$ gallons whale-oil soap. Used as a winter wash for scale. Apply at a temperature of about $130^{\circ} \mathrm{Fahr}$.

Soda wash.-Dissolve $1 / 2$ pound of common washing-soda in a pail of water. For scale and borers.

Sulphide of soda wash (Hilgard's).-Dissolve 30 pounds of whaleoil soap in 60 gallons of water, by heating the two together thoroughly. Then boil 3 pounds of American concentrated lye with 6 pounds of sulphur and 2 gallons of water. When thoroughly dissolved it is a dark brown liquid, chemically called sulphide of soda. Mix the two-the soap and the sulphide-well, and allow them to boil half an hour. Then add about 90 gallons of water to the mixture, and it is ready for use. Apply it warm, by means of a spray-pump. Used warm, its effect is better and less material is required than when cold. For scale on deciduous trees in summer. (Califormian.)

Sulphar.-Fumes of sulphur is destructive to insects, but should be carefully used or plants will be injured. For greenhouse use, few insecticides are superior. The sulphur should be evaporated over an oil-store, until the room is filled with the vapor. The sulphur should never be burned. as burning sulphur kills plants.

sulphur and snuff, -1 pound of flowers of sulphur, 1 pound of Scotch snuff, 1 pound of quicklime, $1 / 2$ pound of lamp-black, 1 pound of soft soap, with sufficient water to make them into the consistency of paint. Wash erery branch, from the grounds upwards, with a common paint-brush before the blossom-buds begin to swell. For plant-lice.

Sulphur and whale-oil soap wash.-Boil $1 \frac{1}{2}$ gallons of water, add $1 / 8$ pound of sulphur and boil 15 minutes. To this add a pound of whale-oil soap and boil for five minutes. Let stand 
Sulphur and whale-oil soap wash, continued.

for a week. When wanted for use, mix 1 pound of the compound to a gallon of water, and apply as a spray at a temperature of $130^{\circ}$ Fahrenheit. Used for various burrowing larvæ, as the gooseberry fruit-worm and the currant borer, as a repellent.

Tobacco.--Used in the following ways:

1. Tobacco-water, used with whale-oil soap.

2. Dust.

3. Fumes. Burn dampened tobacco stems.

4. Nicotyl. Steep tobacco-stems in water and evaporate the water.

5. Tea, or common decoction. Boil the stems or dust thoroughly, and strain. Then add cold water until the decoction contains 2 gallons of liquid to 1 pound of tobacco.

Whale-oil soap. -1 pound whale-oil soap to 5 gallons of water. For mealy bugs and similar insects. It will injure some tender plants.

White hellebore.-A light brown powder made from the roots of the white hellebore plant (Veratrum album), one of the lily family. It is applied both dry and in water. In the dry state, it is usually applied without dilution, although the addition of a little flour will render it more adhesive. In water, 1 ounce of the poison is mixed with 3 gallons. Hellebore soon loses its strength, and a fresh article should always be demanded. It is much less poisonous than the arsenites.

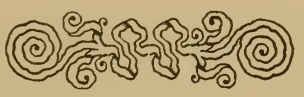

The advent of spraying marks a new era in borticulture. 


\section{CHAPTER II.}

\section{Injurious Insects, with Remedies and Preven}

\section{TIVES.}

Angleworm or Earthworm. The common angleworm often d3stroys greenhouse plants by its burrowing. It is sometimes annoying in gardens also.

Remedy.-Lime-water applied to the soil.

Aphides or Plant-Lice, and Bark-Lice. Minute insects of various kinds, feeding upon the tender parts of many plants.

Remedies.-Kerosene emulsion. Kerosene-and-water emulsion. Hot water (about $125^{\circ}$ ). Coal-tar fumes. Potash. Fish-oil soap. Tobacco-water, and fumes. Alcoholic and water extracts of pyrethrum. Hughes' fir-tree oil.

Apple. Apple-Buccelatrix (Bucculatrix pomifoliella, Clemens). -A minute yellow or green larva feeding upon the upper surface of the leaves, causing the lower surface to turn brown. The cocoons are white and slender and are laid side by side upon the under sides of twigs, where they are conspicuous in winter.

Remedies.-Burn cocoons in winter or apply strong kerosene emulsion to them. Arsenites for the larvæ in summer.

APPLE-CCRCelio (Anthonomus quadrigibbus, Say).-A soft white grub, about half an inch long, living in the fruit.

Remedy.-Arsenites, as for codlin-moth.

Apple Flea-Beetle (Graptodera foliacea, Lec).-Beetle, onefifth inch or less long, feeding upon leaves.

Remedy.-Arsenites.

APPLE-MAGGOT (Trypeta pomonella, Walsh).--Maggot; infests fall apples mostly, occasionally attacks winter fruit. It tunnels apples through and through, causing the fruit to fall to the earth. 
Apple (Apple-Maggot), continued.

Remedies.-Immediately destroy all infested fruit, pomace, and apple-waste from the house. If the orchard is in sod, burn the grass under the trees in fall or spring; if in cultivation, spade or plow up the soil under the trees in spring. Orchards in sandy soil and with a southern exposure are most affected.

BARK-Louse (Mytilaspis poimorum, Bouché).-Minute insects feeding upon the tender shoots. Later in the season the insect secretes a scale under which it lives. The old scales become conspicuous on the twigs.

Preventive.-Plant unaffected trees.

Remedies.-Spray with kerosene emulsion, carbolic-acid wash, soda wash, or oap-and-soda wash, when shoots start. Wash limbs with soap-suds or lye water. Scrape off lice.

BLIgHT.-See under Pear in Chapter IV.

Bud-Mотн (Tmetocera ocellana, Fabr.) -A minute insect, destroying the flower-buds of apples, pears, plums, etc.

Remedy.-Arsenites applied when the buds begin to swell. and again ten days later. Burn infested leaves in the fall.

Canker-Worm (Anisopteryx vernata, Peck).-Larva ; a "measuring worm" an inch long, dark and variously striped, feeding upon the leaves.

Preventive.-Bands smeared with tar or printer's ink, or similar devices, placed about the trunk of the tree to prevent the wingless females from climbing.

Remedies.-Arsenites. Jar the worms into straw, and burn the straw.

Conlin-Mотн (Carpocapsa pomonella, Linn),-Larva, threefourths inch long, pinkish, feeding in fruit; two broods.

Remedies.-Arsenites applied just after the blossoms fall and again ten days or two weeks later. Swine in the orchard. Cloth band about the trunk of the tree, which is examined at intervals of seven to nine days for larvæ and chrysalids.

FALL Web-Worm (Hyphantria textor, Harris).-Hairy larvæ, about an inch long, varying from gray to pale yellow or bluish black, feeding upon the leaves of many trees, feeding in tents or webs.

Remedy.-Destroy by burning the webs, or removing them and crushing the larvæ. 
Apple, continued.

Flat-Headed Borer (Chrysobothris femorata, Fabr.).-Larva about an inch long, flesh-colored, the third segment ("head") greatly enlarged; boring under the bark and sometimes into the wood.

Preventive.-Soap and carbolic-acid washes applied early in June and July. Keep trees vigorous.

Remedies.-Dig out the borers. Encourage woodpeckers. Pear Twig-Beetle.-See under Pear.

Plum-Curculio (Conotrachelus nenuphar, Herbst).-Beetle; punctures the fruit and causes it to become distorted.

Remedies.-Arsenites. Plant plum trees at intervals throughout the orchard to attract the curculio, and fight the insects on the plums. See under Plum .

Root-Louse (Schizoneura lanigera, Hausm.).-A minute insect which causes swelling upon the roots of the tree, impairing its vitality, or killing it. In another form the insect attacks the young branches. It is then conspicuous from its cottony covering. The treatment for aphis is useful here.

Remedy.-Hot water. Scalding hot water may be poured on the bare roots of trees standing in the soil, or nursery stock may be dipped in water having a temperature of $120^{\circ}$ to $150^{\circ}$. Kerosene emulsion or tobacco dug in about the tree. Infested nursery trees should be dipped in kerosene emulsion. Mulching about trees is said to bring the lice nearer the surface.

Rose-BeEtle.-See under Rose. There is practically no remedy for the rose-beetle on large orchard trees. Ravages can be prevented, to a large extent, by the lime spray and the emulsions.

ROUND-HEADED BoRERs (Saperda candida and S. cretata, Fabr.). -Larva, an inch long when mature; bores into the tree. It remains in the larval state three years.

Preventive.-Soap and carbolic-acid washes applied early in June and July.

Remedies.-Dig out borers in the fall. Insert a wire into the holes.

Tent-Caterpillars (Clisiocampa Americana and C. sylvatica, Harris).-Larva, nearly two inches long, spotted and striped with yellow, white and black; feeding upon the leaves. 
Apple (Tent Caterpillars) continued.

Remedies.-Arsenites, as for codlin-moth. Burn out nests with torch. Pick off egg-masses from twigs during winter and spring.

Tessock-Мотн (Uryyia leucostigma, Sm. and Abb.).-A handsome caterpillar, an inch long, bright yellow with red markings, very hairy. Eats the leaves.

Remedy.-Arsenites.

TwIG-Boren (Amphicerus (Bostrichus) bicaudatus, Say).-Beetle, three-eighths inch long, cylindrical and dark brown, boring into twigs of apple, pear and other trees. The beetle enters just above a bud.

Remedy.-Burn the twigs. Catch insects in mating season.

Twig-Pruners (Elaphidion parallelum, Newm., and E. villosum, Fabr.).-Yellowish white ldrvæ, about a half inch long, boring into young twigs, causing them to die and break off.

Remedy.-Burn the twigs.

Apricot. Pear Twig-Beetle. See under Pear.

Plem Curcclio. See under Plum.

Asparagus, Asparagts-Beetle (Crioceris asparagi, Linn.).Beetle, less than one-fourth inch in length, yellow, red and shining black, with conspicuous ormamentation, feeding upon the tender shoots. Larva feeds upon the leaves and tender bark.

Remedies.-Freshly slaked lime dusted on before the dew has disappeared in the morning. Poultry. Draw the nand over the stalks from bottom to top, crushing the beetles; repeating two or three times during the season will keep them in check.

Aster. Aster-Worm. A small larva boring in the stem of garden asters about the time they begin to flower, causing the heads to droop.

No remedy is known, but all infested stalks should be burned.

Bean. Beax-WeEvil or Beax-Bug (Bruchus obsoletus, Say).Closely resembles the pea-weevil, which see for description and remedies.

Bag-Worm or Basket-Worm (Thyridopteryx ephemeroformis, Haw). -Larva working in singular dependent bags, and feeding upon many kinds of trees, both evergreen and deciduous. 
Bag-Worm or Basket-Worm, continued.

In winter the bags, empty or containing eggs, are conspicuous, hanging from the branches.

Remedies.-Hand-picking. Arsenites.

Bark-Lice. See under Aphides.

Blackberry. CANE-BoRER. See under Raspberry.

Rоот Gall-Fly. See under Raspberry.

Sxowy CRICkEt. See under Raspberry.

Blister-Beetle (Lytta, two or three species). Soft-shelled, longnecked and slim black or gray spry beetles, feeding upon the - leaves of many trees and garden plants.

Remedies.-Arsenites. Jarring.

Cabbage. CaBbage-Worn, or CABBaGe-BUtTerfly (Pieris rapa, Linn.).-Larva an inch long, green with yellow and black markings, feeding upon the heads; two broods.

Remedies.-Pyrethrum mixed with flour, or in water decoction. Hot water (temperature from $140^{\circ}$ to $160^{\circ}$ ), applied forcibly in a fine spray. Kerosene emulsion. Lye wash. Arsenites: 1 ounce Paris green or London purple to 6 pounds flour, applied while the plant is wet; should not be used after the plant begins to head. Salt water sprinkled into the head. Pyrethrum, dry or in decoction.

Green LetTuCe-Worm. See under Lettuce.

Harleguin CabBage-Beg (Strachia histrionica, Hahn),-Bug about a half inch long, gaudily colored with orange dots and stripes over a blue-black ground, feeding upon cabbage; two to six broods.

Remedies.-Hand-picking. Place blocks about the patch and the bugs will collect under them. In the fall make small piles of the rubbish in the patch and burn them at the approach of winter.

MAgGot (Anthomyia brassica, Bouche).-A minute white maggot, the larva of a small fly, eating into the crown and roots of young cabbage and cauliflower and turnip plants.

Remedies.-There are no remedies specific for the pest; the best one can do is to remove the plantation to a new plot, as far away as possible, each year. When the plants are in a hotbed, maggots ean be destroyed by inserting bisulphide of carbon into the soil. Puddle the plants when transplanting in a puddle to which sulphur has been added, and sprinkle sulphur about the plants after they are set. Liquid 
Cabbage, continned.

manure applied to the plants is said to drive away the insects. All infested plants should be burned.

The "club-root" of cabbage is not due to the maggot, but to a fungus (which see).

Carrot. Parsley-Worm. See under Parsley.

Cauliflower. CaUliflower or CABBaGe-Worm. See under Cabbage.

Maggot. See under Cabbage.

Celery. Green Letruce-Worm. See under Lettuce.

Parsley-Wory. See under Parsley.

Cherry. Canker-Worm. See under Apple.

Plum-Curculio. See under Plum.

Rose-Beetle. See under Rose and Apple.

Sleg (Selandria cerasi, Peck).-Larva, one-half inch long, blackish and slimy, feeding upon the leaves; two broods.

Remedies.-Arsenites, for the second brood (which usually appears after the fruit is off), and for the first brood if the trees are not bearing. Hellebore in water. Pyrethrum. Air-slaked lime. Road-dust. Catch mature insects by jarring trees late in the evening or early in the morning.

Chrysanthemum. Green Lettrce-Worm. See under Lettuce.

Chrysanthendu Leaf-Miner (Oscinis sp.).-Works upon the leaves of the chrysanthemum.

Remedy.-Hand-picking.

Corn. Bud-Worm. See Tomato Fruit-Worm.

Cornstalk-Borer (Helotropha atra, Get.).-Larva, gray and striped, boring into the stalk.

Remedies.-See Cut-Worm.

GrarN-APHodrus (Aphodius granarius, Linn.).-Beetle, oneeighth inch long, shining black, feeding on kernels in the ground before they sprout.

Remedy.-Soak kernels in water, then stir them in a mixture of Paris green, one part to twenty parts of flour.

Cranberry. Cranberry-ApHis or Louse.

Remedy.-Flooding. See also under Aphides.

FIre-WorM, or CraNberry-Worm (Phopobota vacciniana, Packard).-Small larva, green, feeding upon the shoots and young leaves, drawing them together by silken threads; two broods.

Remedies.-Flooding for two or three days. Arsenites. Attract the moths to fires at night. 
Cranberry, continued.

Cranberry Saw-Fly (Pristiphora identidem, Norton).-Larva, less than one-half inch long, greenish, feeding upon the leaves; two broods.

Remedy.-Flooding. Probably hellebore and arsenites.

Weevil (Anthonomous suturalis, Lec.).-Beetle, less than onefourth inch long; cuts off the flower-buds.

Remedy.-Flooding.

Cucumber. CuCUMBer or PICKLE-WORM (Edioptis nitidalis, Cram.)-Larva, about an inch long, yellowish white, tinged with green, boring into cucumbers; two broods.

Remedies,-Hand-picking at the first appearance of the caterpillars. Destroy infested fruits.

Melon-Worm.-See under Melon.

Spotted Cucumber-Beetle (Diabrotica 12-punctata, Oliv.).Beetle, yellowish and black-spotted, about one-fourth inch long, feeding upon the leaves and fruit. Sometimes attacks fruit-trees, and the larva may injure roots of corn.

Remedy.-Same as for Striped Cucumber-Beetle.

Striped Cucumber-Beetle (Diabrotica vittata,Fabr.).-Beetie, one-fourth inch long, yellow with black stripes, feeding on leaves. Larva, one-eighth inch long and size of a pin, feeding on roots; two broods.

Preventive.-Cheap boxes covered with thin muslin placed over young plants; or screens of mosquito-netting.

Remedies.-Arsenites in flour. Ashes, lime, plaster or fine road-dust sprinkled on the plants every two or three days when they are wet. Air-slaked lime. Plaster and kerosene. Tobacco powder, applied liberally. Apply remedies when dew is on, and see that it strikes the under side of the leaves.

Currant. Borer (Ageria tipuliformis, Linn.).-A whitish larva, boring in the canes of currants, and sometimes of gooseberries. The larva remains in the cane orer winter.

Remedy. - In fall and early spring cut and burn all affected canes. These canes are distinguished before cutting by lack of vigor, and by limberness.

Currant-Worm, or Currant and Gooseberry Saw-Fly (Nematus ventricosus, Klug).-Larva, about three-fourths inch long, yellow green, feeding upon the leaves of red and white varieties; two to four broods.

Remedies.-White hellebore, applied early. Arsenites for the early brood. 
Currant, continued.

Currant Meastring or Span-Worm (Eufitchia (Abraxis) ribearia, Fitch.).-Larva somewhat over an inch long, with stripes and dotted with yellow or black, feeding upon the leaves.

Remedies.-Hellebore, applied stronger than for currani worm. Arsenites, if the bushes are not bearing. Hand picking.

Four-striped Plant-Bug (Pocilocapsus lineatus, Fabr.).-A bright yellow black-striped bug about one-third of an inch long, puncturing the young leaves and shoots of many plants.

Remedy.-Jarring early in the morning. Kerosene emulsion when the bugs are young.

Green Leaf-Hopper (Empoa albopicta, Forbes).-Small insect working upon the under surface of currant and gooseberry leaves. Also upon the apple.

Remedy.-Pyrethrum. Kerosene emulsion.

Green Leaf-Hopper (Typlocyba albopicta, Forbes).-A pale green insect about one-tenth inch long, feeding upon leaves of currants and gooseberries, also upon the apple, causing white spots to appear upon the upper surfaces.

Remedies.-Pyrethrum, applied before the insects are fully grown. Tobacco dust.

Cut-Worm. Various species of Agrotis and related genera. Soft brown or gray worms, of various kinds, feeding upon the roots, crown, or even the tops of plants.

Preventives and Remedies.-Encircle the stem of the plant with heavy paper or tin. Arsenites sprinkled upon small bunches of fresh grass or clover, which are scattered at short intervals about the garden towards evening. They will often collect under boards or blocks. Arsenites mixed with shorts, and placed about the plants. Make two or three deep holes by the side of the plant with a pointed stick; the worms will fall in and cannot escape. Dig them out. Plow infested land in fall to give birds a chance to find the worms. Kainit or muriate of potash applied liberally as a fertilizer has been advised.

Cut-Worm, Climbing. Several species of Agrotis. The worms climb small trees of various kinds at night and eat out the buds. 
Cut-worm, Climbing, continued.

Preventive.-Place strips of tin or bands of tar about the trunk. Dig a small circular hole, with perpendicular sides, about the base of the tree.

Remedies.-Arsenites. Hellebore.

Dahlia. Four-stripen Plaxt-Bug. - See under Currant.

Green Lettuce-Worm.-See under Lettuce.

Deutzia. Four-Striped Plast-Bug.-See under Currant.

Egg-Plant. Potato-Beetle.-See under Potato.

Elm. Elm Flea-Beetle (Galleruca xantho-melona, Schr.).-A small beetle, imported from Europe, which causes great devastation in some of the eastern states by eating the green matter from elm-leaves, causing the trees to appear as if scorched.

Remedy.-Arsenites with kerosene emulsion.

Canker-Worm.-See under Apple.

Willow-WorM.-See under Willow.

Endive. Green Lettuce-Worm.-See under Lettuce.

Flea-Beetle (Phyllotreta vittata, Fabr.; Haltica striolata, Harris). -A minute black-spotted beetle, feeding upon many plants, as turnip, cabbage, radish, mustard, potato, strawberry and stocks. It jumps upon being disturbed. Closely related species attack various plants. Very destructive to plants which are just appearing above the surface.

Remedies.-There are no reliable preventives or remedies. Arsenites, applied dry while the dew is on, are good. Land plaster, lime, ashes, and tobacco-dust, applied in the same manner, are more or less effective. Tobacco decoction used very liberally. Wood-ashes applied liberally. Sometimes ashes injure the plants. Kerosene emulsion thrown with great force against the plants. Calomel, mixed with flour or ashes. The same remedies apply to other flea-beetles.

Gipsy-Moth (Ocneria dispar, Linn.)-Larva, nearly two inches long when mature, very hairy, nearly black, with a yellow stripe along back and sides. Devour many kinds of foliage. Confined to eastern Massachusetts, where it was introduced from Europe about 1869. It is feared that it will become a serious pest.

Remedy,-Spray with arsenites as soon as the caterpillars hatch in the spring. 
Gooseberry. Cukrant-Boner.-See under Currant.

Currant Measuring or Span-Worm.-See under Currant.

Four-striped Platt-Bug.-See under Currant.

Gooseberry or Currayt-Worm.-See under Currant.

Gooseberky Fruit-Worm (Dakruma convolutella, Hubn.).Larva, about three-fourths inch long, greenish or yellowish, feeding in the berry, causing it to ripen prematurely.

Preventive.-Spray just before eggs are laid with the sulphur and whale-oil soap wash.

Remedies.-Destroy affected berries. Clean cultivation. Poultry.

Grfey Leaf-Hopper.-See under Currant.

Grape. APple-tike Boker.-_See under Apple.

Grape-berry Worm (Eudemis lotrana, Schiff.).-Larva, about one-fourth inch long, feeding in the berry, often securing three or four together in a web; two broods.

Remedy.-Burn the affected berries before the larva escapes.

Grape-Curculio (Craponius incqualis, Say.).-Larva small, black with a grayish tint. Infests the grape in June and July, eausing a little black hole in the skin and a discoloration of the berry immediately around it.

Remedics.-Jarring and removing berries. The beetle may be jarred down on sheets, as with the plum-eureulio. Bagging the clusters.

Grape-SeEd Wory (Isosuma vitis, Saunders).-A minute grub, living in the seed of the grape and causing it to become distorted. The injured grapes shrivel.

Remedy.-Burn the affected fruit.

Grape-Slug or SAw-Fly (Selandria vitis, Harris).-Larva, about one-half inch long, yellowish green with black points, feeding upon the leaves; two broods. .

Remedies.-Arsenites. Hellebore.

Grape-vine Fidia (Fidia viticida).-Beetle, resembles the rose-bug, somewhat shorter and broader. It appears during June and July, riddling the leaves.

Remedies.-Jarring the trees; the least jar is sufficient. Poultry.

Grape-vine Flea-Beetle (Graptodera chalybea, Illig.).-Beetle, about one-fourth inch long, feeding upon the buds and tender shoots in early spring. 


\section{Grape (Grape-vine Flea-Beetle), continued.}

Remedies.-Arsenites. The beetle can be caught by jarring on cold mornings.

Grape-vine Root-Borer (Egeria polistiformis, Harris).Larva, one and one-nalf inch or less long, working in the roots.

Preventive.-Mounding as for the peach-tree borer.

Remedy.-Dig out the borers. Apply scalding water to the roots.

Grape-vine SPHivx (Darapsa myron, Cramer).-A large larva, two inches long when mature, green with yellow spots and stripes, bearing a horn at the posterior extremity, feeding upon the leaves, and nipping off the young clusters of grapes; two broods.

Remedy.-Hand-picking.

There are other large sphinx caterpillars which feed upon the foliage of the vine and which are readily kept in check by hand-picking.

Phylloxera (Phylloxera vastatrix, Planchon).-A minute insec, preying upon the roots, and in one form causing galls upon the leaves.

Preventive.-As a rule, this insect is not destructive to American species of vines. Grafting upon resistant stocks is the most reliable method of dealing with the insect yet known. This precaution is undertaken to a large extent in European countries, as the European vine is parti ularl: subject to attack.

Remedies.-There is no reliable remedy known. Burn affected leaves. Bisulphide of carbon poured in holes in the ground, which are quickly filled, is sometimes effect:v Carbolic acid and water used in the same way is also recommended. Flood the vineyard.

Rose-BeEtle.-See under Rose.

SNowy CRicket.-See under Raspberry.

THIIP or LEAF-HOPPER (Erythroneura vitis, Harris). - In various stages, one-tenth inch or less long; feeding on leaves, causing them to appear scorched.

Remedies.-Sticky fly-paper secured to a stick and earried over the vines, whil another person scares up the insects. Attract to lights at ni ht. Kerosene emulsion. In houses, 


\section{Grape (Thrip or Leaf-Hopper), continued.}

tobacco smoke, pyrethrum poured upon coals held under the vines, syringing with tobacco-water or soap-suds. Fumigation in the field should be done before the insects develop wings-late in July or in carly August (in the north). Rake ground clean about vines late in fall in order to expose insects to the weather. It has been found in California that thrips can be greatly lessened by feeding off the leaves with sheep, soon after the grapes are picked.

Grasshoppers. - If these pests become serious, they may be kept in check by the following means: Place a tablespoonful of poisonous bait by the side of each tree or vine. The bait is made of 40 pounds bran, 15 pounds middlings, 2 gallons syrup, 20 pounds arsenic; mix with soft water. Costs 25 to 75 cents per acre. Or Paris green spray may bè used.

Hollyhock. BᄃG (Orthotylus delicatus, Uhl.).-A small green bug, attacking the hollyhock with great damage.

Remedies.-Kerosene emulsion. Pyrethro-kerosene emulsion.

Lawns. ANTs (Formica sp.).-Insects burrowing in the ground, forming "ant-hills."

Remedy.-A tablespoonful of bisulphide of carbon poured into holes six inches deep and a foot apart, the holes being immediately filled up.

Leaf-Crumpler (Phycis indigenella, Zeller).-Larva, brown, wrinkled, found on the inside of leaves, which it brings together in masses and attaches them to each other and to the twigs by means of silken threads. The next season young worms appear from the mass and feed on the new crop of leaves.

Remedy.-Gather the masses and burn them.

Lettuce. Apmis or Green-Fly.-A plant-louse on forced lettuce

Preventive.-Tobacco dust applied on the soil and plants as soon as the aphis makes its appearance, or even before. Renew every two or three weeks if necessary. Fumigate with tobacco.

Greex Letruce-Worm (Plusia brassica, Riley).-Larva, somewhat over an inch long, pale green, with stripes of a lighter color, feeding upon the leaves of many plants, as cabbage, celery and endive.

Remedy.-Pyrethrum diluted with not more than three times its bulk of flour. Kerosene emulsion. Hot water. 
Lire.-See Aphides.

May-Beetle or May-Bug (Lachnosterna fusea, Frohl.)-A large and familiar brown beetle, feeding upon the leaves of many kinds of trees. The common white grub is the larval state. It often does great damage to sod and to strawberries.

Remedics.-For beetle, use arsenites, or jar them early in the morning. For grubs, plow up the lawn so as to expose them to field-birds and poultry, or turn in hogs.

Mealy Bng (Dactylopius adonidum, Linn.).-A white seale-like insect attacking gre ouse plants.

Remedies.-Alcohol s decoction of pyrethrum. Knock them off with a hose. Whale-oil soap. Carbolic acid and soap. Removing insects with brush on tender plants. Whiskey, applied with a brush. Fish-brine.

Melon. Melox-WorM (Eudioptis hyalinata, Linn.).-Larva, some over an inch long, yellowish green and slightly hairy, feeding on melon-leaves, and eating holes into melons, cucumbers and squashes; two or more broods.

Remedy.-Hellebore.

Spotted Ceccmber-Beetle.-See under Cucumber.

Striped Cuctuber-Beetle.-See under Cucumber.

SQUASH-VINE Root-Borer.-See under Squash.

Mite (Tetranychus bimaculatus, Harvey).-Much like red-spider in size and shape, but light-colored, with two dark spots behind. Feeds upon the under side of the leaves of many greenhouse plants. A very serious pest. Evidently known also as "Verbena Mite."

Remedy.-Hughes' fir-tree oil.

Mnshroom. MUshroox-FuY.-The larva bores through the stems of the mushrooms before they are full-grown.

Preventive.-Keep the beds cool so that the fly cannot develop. When the fly is present, growing mushrooms in warm weather is usually abandoned.

Onion. MagGot (Anthomyia cuparum, Meigen).-Nearly indistinguishable from the cabbage-maggot, which see.

Orange. KATYDID (Microcentrum retinervis, Burm.).-A large green grasshopper-like insect, feeding upon the foliage. It is largely kept in check in some localities by a parasitic chalcid fly.

Remedy.-Collect the eggs, which are conspicuous on the borders of the leaves. 
Orange, continued.

LEAF-Notcher (Artipus Floridanus, Horn).-Beetle, one-fourth inch long, greenish blue or copper-colored, eating the edges of the leaves.

Remedy.-Jarring.

Mite (Tetranychus 6-maculatus).

Remedies.-Kerosene emulsion. Sulphur. Practice clean culture.

Scale.-Many species, preying upon the leaves and shoots.

Remedies.-Kerosene emulsion applied with a brush or in spray, just before the trees bloom, and at intervals of two or three weeks as occasion may require. Lye wash. Lyeand-sulphur wash. Pyrethrum decoction. Resin and fishoil soap. When young the scale is more easily destroyed.

Parsley. Parsley-Worm (Papilio Asterias, Cramer).-Larva, inch and a half long, light yellow or greenish yellow with lines and spots; feeding upon leaves of parsley, celery, carrot, etc. When the worm is disturbed, it ejects two yellow horns with an offensive odor, from the anterior end.

Remedies.-Hand-picking. Poultry are said to eat them sometimes.

Parsnip. Parslex-Worm.-See under Parsley.

Paissip Web-Worm (Depressaria heracliana, De Geer).-Larva, about a half inch long, feeding in the flower-cluster and causing it to become contorted.

Remedies.-Arsenites, applied as soon as the young worms appear, and before the cluster becomes distorted. The worms are easily disturbed, and hand-picking is often advisable. Burn the distorted umbels.

Pea. Pea-Weevil or Pea-Bug (Bruchus pisi, Linn.).-A small brown-black beetle, living in peas over winter. The beetle escapes in fall and spring and lays its eggs in young peapods, and the grubs live in the growing peas.

Preventive.-It is said that coal-ashes or sand saturated with phenyl and sown with the peas will prevent attack.

Remedies.-As soon as the mature peas are picked, and while the grubs are only partly grown, subject the peas to a temperature of $145^{\circ}$ for an hour. The seed will not be injured. The ripe peas may also be confined in some tight receptacle, and a little bisulphide of carbon added. 
Peach. APHIS (Aphis persica-niger, Smith).-A small black or brown plant-louse which attacks the tops and roots of peach trees. When upon the roots it is a very serious enemy, stunting the tree and perhaps killing it. Thrives in sandy lands.

Remedies.-Kerosene emulsion. Tobacco decoction. Tobacco hoed in about the tree will destroy the root-colonies.

Apple-tree Borer.-See under Apple.

Flat-headed Borer.-See under Apple.

KATYDID. - This insect is often troublesome to the peach in the southern states in early spring, eating the leaves and girdling young stems.

Remedy.-Poisoned baits placed about the tree.

Peach-тwig Мотн (Anarsia lineatella, Zeller).-The larva of a moth, a fourth inch long, boring in the ends of the shoots; it sometimes artacks the apple and strawberry-roots.

Remedy.-Burn the infested twigs.

Peach-Louse or ApHis (Myzus persica, Sulzer).-A small insect feeding upon the young leaves, causing them to curl and die.

Remedies.-Kerosene emulsion. Soap-and-soda wash. Soapwater. Soap and arsenites.

Plum-Curculio.-See under Plum.

Peach-tree Borer (Egeria exitiosa, Say).-A whitish larva, about three-fourths inch long when mature, boring into the the crown and upper roots of the peach, causing gum to exude.

Preventive.-Make a mound about the tree in early summer, a foot high, and remove it in September; the moth then lays her eggs about the top of the mound, and the tender larva are killed by exposure to the weather. A coat of asbestos roofing applied about the base of the tree is recommended as a preventive. Apply washes as for apple-tree borers. Paint the crown of the tree with ordinary paint, to which Paris green has been added. All preventives are unsatisfactory however, and the only safety is-

Remedy.-Dig out the borers in late fall and early spring.

Red-Legged Flea-Beetle (Haltica rufipes).-A flea-beetle feeding on the leaves of peach trees, often in great numbers. 
Peach (Red-legged Flea-Beetle), continued.

Remedies.-The insects fall at once upon being jarred, and sheets saturated with kerosene may be used, upon which to eatch them. Spray with Paris green.

Rоот-Кхот.-See Root-knot, under R.

Rose-Beetle.-See under Rose and Apple.

Pear. Apple-tree Borer.-See under Apple.

Bud-Motr.-See under Apple.

Codrix-Mотн.-See under Apple.

Flati-headed Borer.-See under Apple.

Midge (Diplosis pyrivora).-A minute fly; punctures the upper part of the pear and lays eggs in it. These hatch into minute grubs which distort and discolor the fruit. It is causing some apprehension in eastern New York and eastward. Introduced about ten years ago from France.

Remedy.-Destroy the infested pears.

Pear-leaf Blister (Phytoptus pyri, Scheuten).-A minute mite which causes black blisters to appear upon the leaves. The mites collect under the bud-scales in winter.

Remedy-Burn the twigs in winter or spray with kerosene emulsion.

Pear-tree Borer (AEgeria pyri, Harris).-A small whitish larva, feeding under the bark of the pear tree.

Remedg-Same as for round-headed apple-tree borer.

PEAR-Twig BeEtle (Xylcborus pyri, Peck).-Brownish or black beetle, one-tenth inch long, boring in twigs, producing effect much like pear-blight, and hence often known as "pearblight beetle." It escapes from a minute perforation at base of bud; probably two broods.

Remedy.-Burn twigs before the beetle escapes.

Psylla (Psylla pyri, Schmidb.).-A curious aphis-like insect infesting the twigs of pear trees when the fruit is setting. They are covered with a waxy material, and in the exuding sap a fungus often develops, giving the twigs a sooty appearance. Often does great damage.

Remcdies.-Difficult to combat. Spray before the flowers appear with some strong soap or lye wash, or kerosene emulsion.

Rose-Beetle.-See under Rose and Apple.

Round-Headed Borer.-See under Apple.

SLug.-See under Cherry. 
Pear, continued.

Twig-GIrdLer (Oncideres cingulatus, Say).-A brownish gray beetle, about one-half inch long, which girdles twigs in August and September. The female lays eggs above the girdle. The twigs soon fall.

Remcdy.-Burn the twigs, either cutting them off or gathering them when they fall.

Twig-Pruner.-See under Apple.

Persimmon. Twig-Girdler.-See under Pear.

Pineapple. Katydid (Acanthaeara similis).-A large katydid which attacks, among other plants, the leares of the pineapple.

Remedies.-Arsenites, before the plants are mature.

Plant-Lice.-See Aphides.

Plum. Bud-Мотн.-See under Apple.

Canker-Worm.-See under Apple.

Curculio (Conotrachelus nenuphar, Herbst.).-Larva, a whitish grub, feeding in the fruit.

Remedies.-Arsenites; apply as soon as the calyx falls and repeat two or three times at intervals of about ten days. Plaster and carbolic-acid mixture. Jarring the beetles on sheets very early in the morning, beginning when trees are in flower and continuing from four to six weeks. Catching beetles under chips or blocks about base of tree, the insects being taken very early in the morning.

Flat-headed Borer.-See under Apple.

Pear-twig Beetle.-See under Pear.

Plum-Godger (Coccotorus scutellaris, Lec.).-A small larva, feeding upon the kernel of the plum. The beetle bores a round hole in the plum, instead of making a crescent mark like the curculio.

Remedy.-Same as for curculio.

Twig-Pruner.-See under Apple.

Slug.-See under Cherry.

Poplar. Cottonworod Leaf-Beetre (Lina seripta, Riley).-A striped beetle feeding on the leares and shoots of poplars and willows.

Remedy.-Arsenites.

WILLOW-Worm.- See under Wiilow. 
Potato. Colorado Potato-Begtle (Doryphora decemlineata, Say).-Beetle and larva feed upon the leaves.

Remedies.-Arsenites. Hand-picking the beetle.

Mole-Cricket (Gryllotolpa borealis, Burm.).--Mature insect curiously formed, whitish, feeding on tubers in low and mucky ground.

Preventive.-Plant potatoes on upland.

Stalk-Weevil (Trichobaris trinotata, Say).-A grub boring in the stalk of the potato near or just below the ground. Serious at the west and in some places eastward.

Remedy.-Burn all infested vines.

Privet or Prim. Privet Web-Worm (Margarodes quadristig malis, Gn.).-Small larva feeding in webs on the young shoots of the privet, appearing early in the season; two to four broods.

Remedies.-Trim the hedge as soon as the worms appear and burn the trimmings. Attract the moths at night by lights. Probably the arsenites will prove useful.

Quince. Round-Headed Borers.-See under Apples. Slug.-See under Cherry.

Radish. MAGGot (Anthomyia raphani, Harris).-Indistinguishable from the cabbage-maggot, which see. Sowing copperas upon the soil before planting is sometimes adopted as a preventive of attack.

Raspberry. CANe-Corer (Oberea bimaculata, Oliv.).-Beetle, black, small and slim; making two girdles about an inch apart near the tip of the cane, in June, and laying an egg just above the lower girdle; the larva, attaining the length of nearly an inch, bores down the cane. Also in the blackberry.

Remedy.-As soon as the tip of the cane wilts, cut it off at the lower girdle and burn it.

RASPBERRY ROOT-BORER (Bembecia marginata, Harris).-Larva about one inch long, boring in the roots, and the lower parts of the cane, remaining in the root over winter.

Remedy.-Dig out the borers.

RASPBERRY SAw-Fly (Selandria mibi, Harris).-Larva about three-fourths inch long, green, feeding upon the leaves.

Remedy.-Hellebore. Arsenites, after fruiting. 
Raspberry, continued.

Root Gall-Fly (Rhodites radieum, Sacken).-A small larva which produces galls, sometimes attaining two inches in diameter, on the roots of the raspberry, blackberry and rose, causing the bush to appear sickly, and erentually killing it.

Remedy.-There is no remedy except to destroy the galls; if plants are badly affected they must be dug up, and burned.

Snowr or Tree-Cricket (Ecanthus niveus, Serv.).-Small and whitish cricket-like insect, puncturing canes for two or three inches, and depositing eggs in the punctures.

Remedy.-Burn infested canes in winter or very early spring.

Red-Spider (Tetranychus telarius, Linn.).-A small red mite infesting many plants, both in the greenhouse and out-of-doors. It flourishes in dry atmospheres, and on the under side of the leaves.

Remedies.-Persistent syringing with water will destroy them, if the spray is applied to the under surface. Fumes of sulphur. Sulphide-of-soda wash.

Rhubarb. Rhubarb-Curculio (Lixus concavus, Say).-A grub three-fourths inch long boring into the crown and roots. It also attacks wild docks.

Remedy.-Burn all infested plants, and keep down the docks.

Root-Knot (Heterodera radicicola).-A disease characterized by the knotting and contortion of the roots of the peach, orange and many other plants. It is usually most destructive on the peach. It is caused by a nematode, or true worm. Gulf States. Attacks green-house plants.

Preventives.-Plant non-infested plants in fresh soil; bud into healthy stocks. Fertilize highly, particularly with potassic fertilizers. Set the trees eight or ten inches deep in high and dry soils. Infested small trees may be remedied, in part at least, by transplanting them into highly manured holes which have been prepared contiguous to them.

Rose. Root GALL-FLy.-See under Raspberry.

Mealy Bug.-On roses, a gill of kerosene-oil to a gallon of water is a good remedy. Syringe the plants in the morning, and two hours later syringe again with clean water. See also under Mealy Bug. 
Rose, continued.

Rose-Beetle, Rose-Chafer or "Rose-Bug" (Macrodactylus subspinosus, Fabr.).-Beetle three-fourths inch long, light brown, feeding upon the leaves, blossoms and fruit.

Remedies.-Hand-picking. Knocking off on sheet early in morning. Bagging. Pyrethrum. Kerosene emulsion. Pyrethro-kerosene emulsion. Eau celeste. It is said to prefer Clinton grapes, spireas, rose-bushes and magnolias, and it has been suggested that these plants be used as a decoy. Open vials of bisulphide of carbon hung in bushes and vines are recommended by some. Sludge-oil soap, a manufactured material. Spraying with dilute lime whitewash. Hot water, at a temperature of $125^{\circ}$ to $130^{\circ} \mathrm{Fahr}$. To prevent the insects from breeding, keep the light lands-in which they breedunder thorough cultivation, and especially never seed them down.

Rose Leaf-Hopper (Tettigonia ros $\infty$ ).-Hopper, very small, white, often mistaken for thrips; lives on the leaves of roses. Various stages of growth may be found in the leaves throughout the summer, and even on indoor plants.

Remedies.-Whale-oil soap. Kerosene. Kerosene emulsion. Nicotyl vapor.

Snails.-These animals are often very troublesome in greenhouses, eating many plants voraciously.

Preventives. - Trap them by placing pieces of turnip, cabbage or potatoes about the house. Scatter bits of camphorgum about the plants. Strew a line of salt along the edges of the bed.

Strawberry. STRAWBerRy Crows-Borer (Tyloderma fragarice, Riley).-White grub, one-ffth inch long, boring into the crown of the plant in midsummer. The mature insect is a curculio or weevil.

Remedy.-Burn over the field after the fruit is picked. If this does not destroy the insects, dig up the plants and burn them.

Grub or Mar-Beetle.-See under May-Beetle.

Strawberry Leaf-Roller (Phoxopteris comptana, Frol.).Larva, less than one-half inch long, feeding on the leares, and rolling them up in threads of silk; two broods.

Remedics.-In flrst stage of attack apply hellebore. Burn the leaf-cases. 
Strawberry, continued.

StrawberRy Root-Louse (Aphis Forbesii, Weed).-From July to the close of the season the lice appear in great numbers on the crowns and in the roots of the plants.

Remedies.-Rotation in planting. Disinfect plants coming from infested patches by dipping the crowns and roots in kerosene emulsion.

StrRAwberry Root-Borer (Anarsia lineatella, Zeller).-Larva. about one-half inch long, whitish, boring into the crown of the plant late in the season and remaining in it over winter.

Remedy.-Burn the plant.

StrawberRy SAw-FLY (Emphytus maculatus, Norton).-Larva, nearly three-fourths inch long, greenish, feeding upon the leaves; two broods.

Remedy.-Hellebore. Arsenites for second brood.

WeEvil (Anthonomus musculus, Say).-Beetle, one-tenth inch long, reddish, feeding on young fruit.

Remedies.-Plaster and crude carbolic-acid mixture.

Sumac. Apple-tree Borer.-Soe under Apple.

Jumping Sumac-Beetle (Blepharida rhois, Forst.).-Larva, half inch long, dull greenish yellow, feeding on leaves; two broods.

Remedy.-Arsenites.

Sweet-Potato. SAw-FLY (Schizocerus ebenus, Norton).-Small larva about one-fourth inch long, working upon the leaves. The fly is about the size of a house-fly.

Remedies.-Hellebore and pyrethrum are to be recommended; also arsenites.

Tomato. Fruit-Worm (Heliothis armiger, Hub.).-Larva, one inch in length, pale green or dark brown, faintly striped, feeding upon the fruit. Also ou corn and cotton.

Remedies.-Hand-picking. White hellebore.

Tomato-Ringer (Stictocephala festina, Say).-A leaf-hopper which injures the stem of the young tomato-plant by puncturing it in a ring. Southward.

No remedy is known.

Tomato-Worm (Macrosila quinquemaculata, Haw.).-A very large green worm feeding upon the stems and leaves of the tomato and husk tomato.

Remedy.-Hand-picking. Hellebore. Arsenites. 
Turnip. MAGGOT.-See under Cabbage.

Weigelia. Four-striped Plant-Bug.-See under Currant.

White Ants, or Termites.-These insects often infest orchard trees in the southern states, particularly in orchards which contain old stumps or rubbish.

Remedy.-The soap-and-arsenites wash brushed over the trunk and branches of the tree.

Willow. WILlow-WorM (Venessa antiopa, Linn.).-Larva, nearly two inches long, black, feeding upon leaves of willow, elm and poplar; two broods.

Remedy.-Arsenites.

Wire-Worm (Various species)._-Slim and brown larvæ, feeding upon the roots of various plants. They are the larvæ of the click-beetle or snapping-beetle.

Remedy.-Arsenites sprinkled upon baits of fresh clover or other material which is placed about the field unđer blocks or boards. Sweetened corn-meal dough also makes a good bait. The best treatment is to plow infested land in the fall. A system of short rotations of crops will greatly lessen injury from wire-worms.

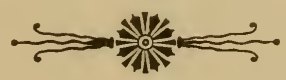

Inasmuch as the growth of one year determines the possibility of a crop in the succeeding year, it follows that spraying, which insures bealthy foliage, may show its greatest result in the following year. This secondary result of spraying-its influence in determining productiveness-is fully as important as its immediate result in securing fair fruit; and it emphasizes the importance of spraying even when there is no fruit. Spraying sometimes fails, but there is no borticultural practice which is surer to bring good results. 


\section{CHAPTER III.}

\section{Fungicides, for Plant-Diseases.}

The results obtained from the use of any insecticide or fungicide depend much upon the operator. Timeliness, thoroughness and persistence are the watchwords of success. It is easier to keep an enemy away than to drive him away. The worst foes are often the smallest ones, and the injury is often done before they are detected. Be ready, and begin early.

The two most important fungicides are ammoniacal carbonate of copper and Bordeaux mixture. The former is cheaper anc more easily applied. The latter is more adhesive ; it cannot be thrown on to large trees. It case any disease is not mentioned, or you are in doubt and cannot secure advice, use one or the other of these preparations.

Copper carbonate costs from 40 to 60 cents per pound.

Copper sulphate costs 6 cents per pound.

Ammoniacal carbonate of copper.-1. Into a vessel having a capacity of 2 quarts or more, pour 1 quart of ammonia (strength 22 degrees Baumé), add 3 ounces carbonate of copper. Stir rapidly for a moment and the carbonate of copper will dissolve in the ammonia, forming a very clear liquid. The concentrated liquid thus prepared may be kept indefinitely. For use, dilute to 25 gallons.

2. Carbonate of copper, 5 ounces; ammonia $\left(26^{\circ}\right), 3$ pints; water, 45 gallons. This is probably the better method.

It is better to wet the carbonate before dissolving it.

For grape-rot and mildew, apple-scab and many other diseases.

Ammoniated copper sulphate (Mixture No. 5 of Dept. of Agriculture).-Equal parts of ammoniated copper sulphate and ammonia carbonate. Put 1 pound of the material in 25 gallons of water, when desired for use. For the same uses as am. moniacal carbonate of copper. 
Blight-powder, Sulphated sulphur,-Prepared by thoroughly mixing from 3 to 8 pounds of anhydrous sulphate of copper with 90 to 100 pounds of flowers of sulphur. For simultaneous treatment of downy mildew, tomato and potato-blight and rot. Little used.

Bordeaux mixture (Copper mixture of Gironde).-1. Dissolve 6 pounds of sulphate of copper in 16 gallons of water. In another vessel slake 4 pounds of fresh lime in 6 gallons of water. When the latter mixture has cooled, it is slowly poured into the copper solution, care being taken to mix the fluids thoroughly by constant stirring. Prepare some days before use. Stir before applying. Stronger mixtures were at first recommended, but they are not now used.

2. Powdered sulphate of copper, 12 pounds in 15-20 gallons water ; lime, 8 pounds in 10-12 gallons of water. When the materials are thoroughly incorporated with the water, add the two mixtures.

For downy-mildew and black-rot of the grape, blight and rot of the tomato and potato, blights of fruits, and many other diseases.

Sometimes the mixture is not washed off the grapes by the rains. In this case, add one quar't of strong cider-vinegar to 5 gallons of water, and dip the grapes, allowing them to remain a few minutes, then rinse once or twice. Dip the grapes by placing them in a wire basket.

Carbolic acid (Phenic acid).-1. Half-pint to 10 gallons of water. For powdery mildew of the vine.

2. Soap-suds, 10 gallons; glycerine, 1 pound; carbolic acid, $1 / 2$ pint. Mix thoroughly to form an emulsion. For orange-leaf scab.

Chloride of iron,-A very dilute solution of chloride of iron has been used with success in combating the coffee disease due to Hemileia vastatrix. The solution is applied to the under surface of the leaves by means of a pulverizator or sprayingapparatus. Its sticky nature causes it to adhere for two months. It is suggestive in connection with some of our plant-diseases.

Copper, Precipitated carbonate of.-Dissolve 2 pounds of sulphate of copper in hot water, and in another vessel 2.5 pounds of sal soda in hot water; when cool, the two are added together with constant stirring. The mixture is then diluted to 25 gallons. For diseases of the grape. 
David's powder.-Dissolve 4 pounds of sulphate of copper in the least possible amount of hot water, and slake 16 pounds of lime with the smallest quantity of water required. When the copper solution and slaked lime are completely cooled, mix them together thoroughly ; let the compound dry in the sun, then crush and sift. Apply with a sulphuring-bellows furnished with an outside receptacle for the powder. For downy mildew and black-rot of the grape, mildew and anthracnose.

Destroying affected parts.-It is important that all affected parts should be removed and burned, if possible. In the fall all leaves and fruit which have been attacked by fungi should be raked up and burned. Diseased kranches should be severed at some distance below the lowest visible point of attack. Fungous diseases often spread rapidly, and prompt action is usually necessary.

Ean celeste.-1 (Audoynaud process). Dissolve 1 pound of sulphate of copper in 2 gallons of hot water. When completely dissolved and the water has cooled, add $1 \frac{1}{2}$ pints of commercial ammonia (strength 22 degrees Baumé). When ready to use, dilute to 25 gallons. For treatment of downy mildew and black-rot of the grape, anthracnose, and blight and rot of the tomato and potato, and many other diseases.

2. Dissolve 1 pound of sulphate of copper in 2 gallons of water. In another ressel dissolve 1 pound of carbonate of soda. Mix the two solutions. When chemical reaction has ceased, add $1 \frac{1}{2}$ pints of ammonia, then dilute to 25 gallons. For the same purpose as No. 1, and probably better.

Grison liquid (Eau Grison).-Prepared by boiling 3 pounds each of flowers of sulphur and lime in 6 gallons of water until reduced to 2 gallons. When settled, pour off the clear liquid and bottle it. When used, mix 1 pint of clear liquid in 100 parts of water. For mildew and powdery mildew of vines.

Podeschard's powder.-Dissolve 45 pounds of sulphate of copper in water. When thoroughly dissolved, pour the solution upon 225 pounds of air-slaked lime, which is surrounded by 30 pounds of ashes to keep the liquid from spreading. After $2 f$ hours add 20 pounds of flowers of sulphur. Thoroughly mix the compound, ashes and all. When dry, sift through a sieve with meshes of one-eighth inch. Will keep for months. For downy mildew, mildew and anthracnose. 
Potassium sulphide.-Used at the rate of $1 / 2$ or $1 / 4$ ounce to the gallon of water. For various mildews, as gooseberry mildew.

Skawinski's powder.-Mix 22 pounds of finely powdered sulphate of copper with 33 pounds of soot or alluvial earth and 165 pounds of coal-dust. For treatment of mildews.

Skawinski's sulphate of iron and sulphoric acid solution.-Sulphate of iron, 110 pounds; sulphuric acid (53 degrees), 11/2 pints; warm water, 22 gallons. Pour sulphuric acid on the crystals of iron, then add the water. Use while warm.

Soda hyposulphite.-1. Half-ounce to 10 gallons of water. For various diseases. Little used now.

2. 1 pound in 10 to 20 gallons of water. For celery leafblight, orange leaf-blight, apple-scab. Should be used as as soon prepared. Little used.

Sulfo-steatite or Cupric steatite.-An exceedingly fine bluish powder composed of steatite, or talc, and about 10 per cent. of sulphate of copper. Considered the most adherent of all fungicide powders. For mildews.

Sulphate of copper.-1. Dissolve $1 / 2$ pound of pure sulphate of copper in 5 to 12 gallons of water. For treatment of downy mildew and black-rot of grape and apple-scab in winter, or in spring before the buds swell.

2. Dissolve 5 to 8 pounds in 10 gallons of water. For soaking grains previous to sowing, to destroy spores of smuts. The Germans use a 1/2-per-cent. solution, and soak the grains for about 16 hours.

Sulphate of iron. - 1 . Simple solution in water of 4 to 8 pounds to the gallon. To be used only as a wash before the buds swell. For anthracnose of the vine and raspberry, etc.

2. For a spray, dissolve about $1 \frac{1}{4}$ pounds to the gallon.

Sulphatine, the Esteve process.-Mix 2 pcunds of anhydrous sulphate of copper with 20 pounds of flowers of sulphur and 2 pounds of air-slaked lime. For mildew, downy mildew and black-rot of grape, tomato and potato-blight and rot.

Sulphide, or sulphuret, of potassium (Liver of sulphur).--Simple solution in water of $1 / 4$ to 1 ounce to the gallon. For mildew in greenhouses, mildew on roses, erinose of vine, orange leaf-scab, celery leaf-blight, pear and apple-scab and various rots.

Sulphide of soda wash (Hilgard's).-Dissolve 30 pounds of whaleoil soap in 60 gallons of water by heating the two together 
Sulphide of soda wash, continued.

thoroughly. Then boil 3 pounds of American concentrated lye with 6 pounds of sulphur and 2 gallons of water. When thoroughly dissolved, it is a dark brown liquid, chemically called sulphide of soda. Mix the two-the soap and the sulphur-well, and allow them to boil for half an hour, then add 90 gallons of water to the mixture, and it is ready for use. Apply it warm by means of a spray-pump. Used warm, its effect is better and less material is required than when coldFor scab diseases.

Sulphur.-In its dry and pulverized state, sulphur, known as flowers of sulphur, is often a valuable fungicide, particularly for surface-mildew. In the greenhouse it may also be used in fumes. Evaporate it over a steady heat, as an oilstove, until the house is filled with the vapor. It should never be heated to the burning point, as burning sulphur quickly destroys most plants. It may also bə used in water, in the proportion of an ounce of sulphur to 5 gallons of water.

Sulphur and lime.-A mixture of sulphur and lime in equal parts by weight. For anthracnose during growing-season.

Some fungicides may be added to London-purple or Parisgreen mixtures, as explained on page 8 .

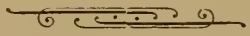

The best spraying machine is the one which throws the finest spray to the greatest distance. 


\section{CHAPTER IV.}

\section{Plant-Diseases:}

WITH PREVENTIVES AND REMEDIES.

Apple. Buight.-The same disease as pear-blight, which see.

Brown-Rot.-See under Cherry.

Powdery Mildew (Podosphera oxycantho, DeBary).-Attacks nursery stocks, covering leaves with a grayish and powdery meal-like mildew.

Remedy.-Ammoniacal carbonate of copper, applied four or five times.

RIPE-Rot or Bitter-Rot. (Glocosporium fructigenum, Berk.).A rot which attacks ripe apples and grapes. It attacks the fruit before it is picked usually, although it may not become apparent until it is stored. Many of the culls in packed fruit are due to this fungus.

Remedies.-Spray the fruit late in the season (beginning early in August) with ammoniacal carbonate of copper, or potassium sulphide ( $1 / 2$ ounce to gallon of water).

RUst (species of Rostelia).-Bright yellow rust appearing on the young leaves and fruit, causing the whole tree to become enfeebled. It is now known that one stage of this fungus is the "cedar-apple" which grows on red cedars and junipers, where it is known as Gymnosporangium. Several species have been described.

Preventive.-Destroy the cedars or keep them free from the "apples." Destroy hawthorns and escaped apples, which are liable to be infested. Some varieties of apples appear to be more susceptible to injury than others.

Remedy.-Spray early with ammoniacal carbonate of copper. 
Apple, continued.

SCAB (Fusicladium dentriticum, Fckl.).-Brown or blackish scab-like spots on the leaves and fruit, arresting growth and causing the parts to become distorted. Very common.

Preventive or Remedy.-Spray with sulphate of copper while the trees are dormant, if apple-scab is feared. Thereafter spray with ammoniacal carbonate of copper. The first application of this should be made as soon as the leaves appear and before the blossoms open, and the second as soon as the blossoms fall. Two or three subsequent sprayings may be necessary at intervals of two or three weeks. Ammoniated copper sulphate, applied as above, has also given good results.

Apricot. LEAF-Rust.-See under Plum.

Balm of Gilead. Leaf-Rcst.-See under Poplar.

Bean. Axthracyose, or PoD-Rust (Gloosporium Lindemuthianum, Sacc. and Magn.).--Reddish brown scab-like spots appearing upon bean-pods, particularly upon the yellowpodded string-beans. It also attacks watermelons.

Preventive, -Plant in dry and airy places, on light soil.

Remedies.-Copper sprays. Sulphur and water.

Bean, Lima. Blight (Phytophthora Phaseoli, Thaxter).-Attacks the pods in August and September, covering them with a white, felted coating. It also attacks the young shoots and leaves.

Remedy.-Bordeaux mixture.

Beet. Rest (Uromyces beta, Pers.).-Powdery reddish brown spots on the leaves of beets in California, often doing much injury.

Remedies.-Copper sprays. Burn the infested leaves.

Blackberry. CAxe-Rust or Axthracxose.-See under Raspberry.

Ren or ORANGE-Rust.-See under Raspberry.

Buttonwood. Leaf-Scorching. Siee under Plane-tree.

Cabbage. Clcb-Root or Club-Foot (Plasmidiophora brassica, Woronin).-A contorted swelling of the root of the cabbage in the field, prerenting the plant from heading and causing it to assume a sickly appearance.

Remedics.-Burn the roots as soon as the disease appears. Alternate crops. It is thought that stable-manures aggrarate the disease. 
Carnation. Rust (Septoria Dianthi, Desm.).-Attacks the leares in large, light brown spots, or occasionally the whole leaf becomes discolored and wilts. Probably introduced from Europe.

Preventives.-If the disease is feared, be careful not to apply water to the leaves. Ammoniacal carbonate of copper or Bordeaux mixture. Burn all infested leaves.

Another Rust (Uromyces caryophyllinus, Schr.) also occurs upon the carnation, producing gray blisters upon the leaves. The treatment is the same as for the above. In both instances, a careful picking and burning of the infected parts is one of the surest preventives of further attacks.

Celery. Celery-leaf Blight, Rest or Sun-Scald (Cercospora Apii, Fries).-Appears in hot and dry places and seasons, about mid-summer. Small yellowish spots appear upon the leఓves; later the leaves turn yellow, then brown, and dies.

Preventive.-Plant in a moist and cool place, and shade the plants if necessary. Destroy all diseased leaves in autumn. Cherry. Browx-Rot (Monilia fructigena, Pers.).-Attacks flowers, leaves and fruit. The flowers die and decay, the leaves become discolored with brownish patches, and the fruit rots on the tree. Attacks also peaches, plums and apples.

Remedies.-Burn all infested fruit and leaves in the fall. Before buds expand in spring spray with sulphate of iron or copper. When the flowers are opening, spray again with ammoniacal carbonate of copper, and repeat the operation at intervals of a week or two until the fruit begins to color. See under Peach.

Leaf-Rtst. See under Plum.

Powdery Mildew. See under Apple.

Corn. Rot.-Due to bacteria. The plants are dwarfed, and unusually siender. The roots become mucilaginous and decay, as do the leaf-sheaths and the ear's.

No remedies or preventives are known except rotation.

Smut (Ustilago Zea-MIays, D. C.).-A fungus attacking the ears of corn, producing familiar black abnormal growths.

Preventive.-Plant seed from clean fields.

Remedies.-Cut out smut and burn it. Soak seed in sulphate of copper before planting.

Cottonwood. Leaf-Rust.-See under Poplar. 
Cranberry. GaLL-Fuxgus (Synchytrium vaccinii, Thomas).-Minute red galls or pimples upon the leaves, flowers and stems, causing the parts to become misshapen and dwarfed.

Remedy.-Burn the infested plants and also wild plants about the bog which are infested. Withholding the water from the bog in winter and spring may subdue it.

SCALD.-Attacking the fruit early in the season, at first producing a scalded appearance, and later decay.

Remedies.-Sanding the bog and keeping water off in summer are partial remedies.

Cucumber. Mildew (Oidium erysiphoides var. Cueurbitarum).A white mold-like mildew which appears in spots upon the leaves of cucumbers, especially under glass.

Remedies.-Evaporated sulphur. Spray with ammoniacal carbonate of copper.

Currant. Rust or Leaf-Spot (Septoria Ribis, Desm.).-Appears about mid-summer, on leaves of white, red and black currants, as whitish spots with black centers. It causes the leaves to fall.

Remedies.-Destroy infested leaves. Spraying with Bordeaux mixture and carbonate of copper, as for grape-rot.

Damping-off.--A term applied to the decay of young seedlings and cuttings at or near the surface of the ground. The trouble is undoubtedly due to a great variety of causes, but it is thought to be oftenest the work of species of fungi of the genus pythium (as Pythium vcxans, $P$. omnivorum and $P$. DeBaryanum). It is probably sometimes due to some fungus which exists in the seed, and in such casesif they could be determined-soaking the seed in carbonate of copper is to be recommended. A confined atmosphere, compact and wet soil, faror damping-off.

Preventives and Remedies.- Ventilate the cutting or seedbeds, do not let the plants crowd, and do not keep very wet, and keep the soil equally moist throughout its depth. When the trouble appears among valuable plants, the healthy ones should be transplanted into fresh soil. Dusting the soil with sulphur, and sifting upon it and the plants very hot clean sand, are to be recommended.

Gooseberry.-Mildew (Sphœrothcca Mors-uva, B. \& C.). - A 
Gooseberry (Mildew), continued.

downy mildew attacking the fruits and young growth of English varieties of gooseberry (varieties of Ribes Grossularia).

Remedy.-Potassium sulphide (liver of sulphur), 1/2 ounce to a gallon of water is a sure remedy, if applied as soon as the leaves begin to unfold, and at intervals of two or three weeks thereafter.

Grape. Anthracnose or Scab (Sphaceloma ampelinum, DeBary). -The fungus attacks the leares, where it forms definite brown spots, and also the young shoots and the fruits, where it forms pits or scabs. Generally distributed east of the Mississippi. Probably introduced from Europe.

Remedies.-It is difficult to combat. Before growth starts, cut out and burn affected canes and then spray with a strong solution of sulphate of iron. After the leaves open, use sulphur and lime powder; or the vines may be sprayed with Bordeaux mixture or ammoniacal carbonate of copper.

Black-Rot (Lastadia Bidwelli, V. \& R.; Phoma uvicola, B. \& C.).-Attacks the young berries. The fruit becomes black, hard, dry, and shrireled, and is corered with minute pimples. Occurs east of the Rocky Mountains, especially southwards. Of American origin.

Preventive. -A board placed over the trellis, as mentioned under the downy mildew, is some protection; but the spray is sure:

Remedies.-Burn infested fruits in autumn. If an attack is feared, spray with a plain solution of sulphate of iron or copper before the buds swell. Thereafter use Bordeaux mixture or ammoniacal carbonate of copper, at intervals of 10 to 15 days, continuing for 5 or 6 applications if necessary. The first spraying is made just before the blossoms open. Perhaps the best method is to use Bordeaux mixture for the first applications, and ammoniacal carbonate of copper for the last one or two, as this remores the danger of discoloring the grapes by the Bordeaux mixture. Very good results are obtained by the continuous use of the carbonate of copper, and it is applied more easily than the Bordeaux mixture.

The cost of spraying grapes six times during the season, including the cost of the chemicals, is estimated at two cents 
Grape (Black-Rot), continued.

per vine for ammoniacal carbonate of copper and three cents for Bordeaux mixture. These figures assume that the best appliances are used, and that the plantation is a half acre or more in extent, and that the copper carbonate costs not to exceed 40 cents per pound and the copper sulphate not to exceed 6 cents per pound.

Note.-The following are synonyms for black-rot: Sphoria Bidwellii, Physalospora Bidwelli, Phoma uvicola, Phoma uvicola var. Labrusca, Spharopsis uvarum, Phoma uvarum, Nemaspora ampelicida, Phyllosticta Labrusca (the "leaf-spot" form), Phyllosticta viticola, Phoma ustulatum, Phyllosticta ampelopsidis, Sacidium viticolum, Septoria viticola, Ascochyta Ellisii. Downy Mrldew, Brown-Rot. (Peronospora viticola, DeBary).Appears in small frost-like patches on the under surface of the leaves, finally causing yellowish discoloration on the upper surface. It also causes the brown-rot of the fruit. The berries remain small and firm, usually not wrinkled, and become brown in color. The disease is worst on thin and smoothleaved varieties, as the Delaware and others. It extends generally throughout the Union. Of American origin.

Preventive.-A wide board nailed flatwise on the top of the trellis so as to protect the vines somewhat, as with a roof, is a considerable protection, as it tends to keep the vines dry. Vines trained against a building rarel $\dot{y}$ suffer.

Remedy.-The same as for black-rot, which see.

Powdery MILdew (Uncinula spiralis, B. \& C.).-Appears early in the season as delicate dust-like patches or covering on the leaves, mostly on the upper surface, and on shoots and fruits. Berries attacked by it become checked in growth, and may remain small and die, or they sometimes grow and crack before death ensues. It attacks grapes in vineries which are not properly ventilated and managed. Occurs generally throughout the Union, but is less destructive than the downy mildew. American origin.

Remedy.-Dry sulphur applied to the vines, two or three times-once when the shoots just begin to push, again when in blossom, and usually again shortly before the grapes begin to turn. Apply in warm and bright weather, after the dew is off. In vineries, the sulphur may be scattered on the 
Grape (Powdery Mildew), continued.

hot pipes. Any of the sprays of copper compounds are specifics.

RIPE-RoT (Glœosporium fructigenum, Berk.).-See under Apple. The treatment for black-rot is efficacious for this.

Hollyhock. RUST (Puccinia Malvacearum, Mont.).-Appears upon leaves of hollyhocks and a few related plants in small, light brown patches. Introduced from Europe, and becoming common in this country.

Remedies.-To destroy the plants is the only general method yet employed to prevent the spread of the disease, but some of the copper fungicides may be used.

Lettuce. MrLdew (Peronospora gangliformis, DeBary).-A delicate mildew, attacking lettuce-leaves and causing yellow or brown spots, and finally killing the leaf.

Preventives. (According to Maynard.)-Grow at a low temperature ( $35^{\circ}$ to $40^{\circ}$ at night, $50^{\circ}$ to $70^{\circ}$ during day); give abundance of plant-food; give abundance of water, but apply it in morning and bright days only; avoid sudden extreme changes of temperature.

Remedy.-Fumes of sulphur.

Maple. LeAf-Spot (Phyllosticta acericola, C. \& E.).-Attacks the leaves of red, silver, and striped maples in spring, causing them to become spotted and unsightly, and lessening the vigor of the tree.

Remedies.-Rake and burn the leaves in autumn. When the leaves are two-thirds grown spray with sulphide of potassium or copper fungicides, and repeat every three or four weeks as long as necessary.

Onion. Rust (Peronospora Schleideniana, Unger).-The leaves turn yellow about the time the onions begin to bottom, or a little later, and wilt and die.

Remedies.-Grow on land not infected, and destroy all affected onions. Spray early with copper fungicides.

SMUT (Urocystis cepulae, Frost).-Attacks the first leaf or leaves of seedling onions, producing dark irregular spots, and killing or weakening the plants.

Remedy.-The sulphur and lime mixture drilled into the ground with the seed; about an ounce of the mixture to 50 feet of drill. 
Orange. Orange-LeAf ScaB (Cladosporium). - The leaves becomo yellow and distorted.

Remedy.-Spray with Grison liquid, or carbolic acid and glycerine mixture.

Peach. Brown-Rot.-See under Cherry.

CURL, LEAF-CURL or "FrenchiNg" (Taphrina deformans, Tul.; written also Ascomyces deformans and Exoascus deformans). -The leaves become blistered and crumpled early in the season and fall off.

Remedies.-Good culture, to enable the tree to put forth new leaves, is to be recommended. Spray in spring, before the buds open, with sulphate of copper or iron, and follow with two or three applications of ammoniacal carbonate of copper or Bordeaux mixture.

Leaf-Rust.-See under Plum.

Powdery Mrldew.-See under Apple.

Rot and Blight (Monilia fructigena, Pers.).-This is the familiar quick rotting of peaches when nearly ripe or after they are picked, and the same fungus causes the blighting of young shoots. It also attacks plums, cherries, a pricots, and to a smaller extent apples and pears.

Preventives.-Burn or bury all affected fruits as soon as they appear. In wet weather, when peaches are rotting badly on the tree, systematic attempts should be made to pick and destroy the injured fruits. Burning or plowing under the leaves in the fall is to be recommended. Before the leaves appear, spray with some copper compound, as sulphate of copper or Bordeaux mixture, and spray thereafter several times. These sprays are not specifies, but they appear to hold the disease in check. It is said that harvested fruit can be preserved for a short time against the fungus by dipping it in a solution of potassium sulphide (liver of sulphur).

Yellows.-The first symptom in bearing trees is usually the premature ripening of the fruit. This fruit contains definite small red spots which extend to the pit. The next stage is indicated by very slender shoots, which branch the first year and which start in clumps from the old limbs, bearing narrow and small yellowish leaves. Later the entire foliage becomes smaller and yellow. In three or four years the tree 


\section{Plant-Diseases.}

Peach (Yellows), continued.

dies. The disease spreads from tree to tree. It attacks trees of any age. Known at present only in regions east of the Mississippi. Peculiar to America, so far as known.

Preventive.-Burn all trees as soon as the disease appears. Laws aiming to suppress the disease should be enacted in all peach-growing states.

Pear. Blight (Micrococcus amylovorus, Burrill).-Distinguished by the blackening of the entire leaf, and the blackening of the bark. Attacks the flower clusters. It may destroy branches or the whole tree. Generally distributed east of the 100th meridian. Known only in America. Attacks the apple.

Remedy.-As soon as the disease is discovered, cut off the affected parts a foot below the point of lowest visible attack, and burn them.

LeAf-Blight and Cracking of the Fruit (Entomosporium maculatum, Lev.; Morthiera Mespili, is the same).-Attacks nursery-stocks of pears, beginning as small and circular brown spots on the leaves; soon the entire leaf turns brown and falls. Also causes the cracking of the fruit.

Remedies.-Bordeaux mixture, eau celeste, or ammoniacal carbonate of copper, applied four or five times. Begin when the leaves are half-grown, and follow at intervals of from two to four weeks.

Rоoт-Roт (Polyporus versicolor, Fries).-Attacks the roots, the white and felt-like threads of the fungus at length becoming very abundant and conspicuous. The trees produce a short and thick growth, the new wood being reddish, the leaves becoming yellowish or bronzed, and there is an unusual tendency to form fruit-buds. The tree may die quickly or may live for several years. The roots rot away and the tree tips over. The disease is worst on poor and dry soils and in grassy orchards.

Remedies.-Give good culture. Remove the earth from the crown and apply a dressing of lime.

Rust.-See under Apple.

SCAB (Fusicladium pyrinum, Fckl.). - Brown or blackish scablike spots on the leaves and fruit, arresting the growth and causing the parts to become distorted. 
Pear (Scab), continued.

Remedy.-Spray several times during June and July with ammoniacal carbonate of copper or Bordeaux mixture.

Plane-Tree. Leaf-Scorchivg (Glocosporium nervisequum, Sacc.). -Attacks the leaves in spring, causing them to appear as if scorched. They finally fall off. Attacks both the native and oriental planes.

Remedy.-Burn all leaves when they fall. Spray with cop per compounds.

Plum. Brown-Rot.-See under Cherry.

Leaf-Rust (Puccinia pruni-spinosce, Pers.).-Small round powdery spots of yellowish brown on the under surface of the leaves, and reddish spots on the upper surface directly above them.

Remedy.-Spray trees early in the season with Bordeaux mixture, ammoniacal carbonate of copper, eau celeste, or other fungicides.

Pldm-Knot or Plum-Wart (Plowrightia [Sphceria] morbosa, Sacc.).-A black and irregular swelling, from one to five or six inches long, appearing on the small limbs of plum and cherry. Peculiar to America. A very serious disease.

Remedies.-Burn all affected parts in the fall. If the knot is found upon a large limb or trunk, cut it out and wash the wound with sulphate of copper. Wash the parts as soon as the swelling begins to appear, with linseed oil, turpentine or kerosene, using the two latter with caution. A paint of red oxide of iron in linseed oil is recommended. Probably spraying with strong copper sulphate solution (10 per cent. solution) or similar mixtures in winter or early spring will prove to be valuable remedies. All remedies are uncertain.

Plum-leaf or Shot-hole Fungus (Septoria cerasina, Peck; Cylindrosporium Padi).-Appears as spots upon the leaves in July, and these spots assume definite outlines, and often fall out, leaving holes like shot-holes. The leaves fall early, pre. venting the fruit from maturing. The disease is sometimes designated simply "Falling of the leaves."

Remedies.-Burn leaves as soon as they fall. Bordeaux mixture or ammoniacal carbonate of copper applied several times during the season, beginning as soon as the leaves appear. 
Plum, continued.

Plum Pockets or Bladders (Taphrina pruni, Tul.).-Causes the fruit to become inflated and hollow. These "bladders" begin to appear soon after the flowers fall, and continue to grow for several months, when they fall. They are at first globular, but finally become oblong, of ten reaching two inches in length. The fungus attacks the fruit of the Chickasaw and American plums, and various species of plum and cherry.

Remedies.-Destroy the "bladders" before they mature, together with small portions of the wood on which they are borne. Spray before buds expand with strong sulphate of copper or iron, and follow with copper fungicides.

Powdery Mildew.-See under Apple.

Rot or Blight.-See under Peach.

Poplar. Leaf-Rust (Melampsora populina, Lév.).-An orange rust attacking, during summer, the leaves of various species of poplar, including the cottonwood, balm of Gilead, etc.

Remedies.-Rake and burn the leaves. Spray with copper compounds.

Potato. Potato-Rot or Blight (Phytophthora infestans, DeBary). The spores first germinate upon the tops or vines, causing the foliage to blight. The disease soon spreads to the tubers, causing discolored and diseased potatoes. It is a "dry rot." The fungus may remain in the tubers during winter.

Preventive.-Plant on light or loamy, well-drained soil Plant only sound and disinfected tubers. Hill deep.

Remedy. - Spray the tops with Bordeaux mixture, or other fungicide, upon the first indication of the blight, and make three or more applications at intervals of ten days or two weeks.

The tubers should be stored in a cool and dry place. Dusting them in the cellar with dry air-slaked lime is to be recommended. Subjecting the tubers to a temperature of $105^{\circ}$ to $110^{\circ}$ for a few days will destroy the fungus and will not injure the tubers for planting.

There is another kind of potato blight and rot widely distributed over the country, and due to a germ or bacterium. The leaves curl, the plant droops and finally dies, and the tubers contract a putrid rot. Very serious. No remedy is known. Practice rotation. 
Quince. LEAF-BRownNess or BLIGHT (Entomosporium maculatum, Lév., var. Cydonia, Sacc.).-Leaves become spotted and then turn yellow and fall. This disease often causes considerable damage. It is nearly identical with leaf-blight of the pear (which see).

Rust.-See under Apple.

Raspberry. CaNe-Rust or ANthracnose (Gloesporium necator, E. \& E.).-The spots or patches of fungus appear on both the canes and leaves. The disease attacks the base of the canes first and spread upwards. It makes sunken patches on the canes and causes the fruit to dry up.

Preventive. - Give plants an abundance of light and air by broad planting and high training.

Remedy.--Spray before the buds swell with sulphate of iron, and follow later with Bordeaux mixture or ammoniacal carbonate of copper. Burn all canes that are past recovery.

Red or Orange-Rust (Cooma luminatum, Link).-Attacks the under surface of the leaves of black and sometimes red raspberries, and of blackberries, in patches of whitish yellow, but the fungus finally covers the whole under surface with an orange-red coating.

Preventive.-Plant such varieties as are least susceptible to attack. Among blackberries, Kittatinny is particularly susceptible.

Remedies.-Burn the plants, roots and branch, as soon as the disease appears. Bordeaux mixture may be tried.

Rose. Leaf-Blight or Black-Spot (Actinonema rosa, Fries). -Attacks the full-grown leaves, first appearing as small black spots, but later covering nearly or quite the whole surface with blotches. The spots have frayed edges. Common in outdoor and house-culture.

Remedies.-In the house, fumes of sulphur. Outdoors, burn the affected leaves and spray with Bordeax mixture or ammoniacal carbonate of copper. Spray before the leaves unfold.

LeAf-Spot (Cercospora rosacola, Pass.).-Black or reddish black spots on the leaves, shading into red at the definite edges. Later the center of the spot becomes light brown or gray. Attacks plants growing outdoors.

Remedies.-Burn diseased parts. Plant in an airy and dry place. Spray with copper fungicides. 
Rose, continued.

MiLdew (Sphaerotheca pannosa, Lév.).-Whitish mildew attacking roses. It is brought on, according to Maynard, by exposure to drafts of extremely cold air when the plants are growing rapidly, by high temperature running the same day and night, by watering just before night, by too little water, by extreme dryness, by poor drainage, by deficiency in plant-food.

Remedies.-Fumes of sulphur. Copper fungicides.

Rust (Phragmidium mueronatum, Winter).-Appear's in small and scattered bright yellow spots or pustules on the leaves, which at length become distorted, and upon the young growth.

Remedy.-Spray with Bordeaux mixture or other fungicides.

Spinage.-Several fungi attack the spinage, of which the following are the worst:

Mildew (Peronospora effusa, Rabenh.).--Producing violet-gray patches upon the under side of the leaves and yellow spots above;

Axthracxose (Colletrotrichum Spinacea, Ell. \& Hals.).-Producing brown and gray blotches upon the leaves;

Leaf-Blight (Phyllosticta Chenopodii, Sacc.).-Forming many minute pimples on the leaf, usually upon its under surface;

Wніт Sмот (Entyloma Ellisii, Hals.).-Covering the whole leaf with a white coat.

Remedies.-No definite remedies are yet known for these diseases. Sprays of some of the sulphur fungicides may check them. Burning all affected plants, and rotation, are to be advised.

Strawberry. MILdew (Sproeotheca Castagnei, Lév.).-A whitish cobweb-like mildew spreading over the fruit and leaves.

Remedy.-If the disease is discovered early enough, some liquid fungicide, as ammoniacal carbonate of copper or Bordeaux mixture, should be employed.

Strawberry Leaf-Blight or Sun-Burn "(Spharella fragario, Sacc., including Ramularia).-Small purple. or red spots appearing on the leaves. They eventually become larger and browner, making the leaf appear blotched.

Remedies.-Spray with Bordeaux mixture or ammoniacal carbonate of copper at intervals of two weeks, beginning 
Strawberry (Strawberry Leaf-Blight or Sun-Burn), continued.

as soon as the fruit is picked. Destroy all affected leaves. The leaves are easily destroyed without injury to the plants by quickly burning off a thin layer of straw which is spread over the patch after the fruit is off.

Sweet-Potato. Black-Rot (Ceratocystis fimbriata, E. \& Hals.).A dry-rot of the tuber, and a black rust upon the stems. Upon the tuber it appears in large scab-like patches, and is usually evident at digging time. It may appear upon the young plants in the hotbed and persist upon them throughout the season.

Remedies.-Rotation of crops. Spray the young plants, if attack is feared, with some copper fungicides.

DrT-Rot (Phoma batata, E. \& Hals.).-The upper end of the tuber becomes dry and wrinkled and bears a multitude of pimples, and its flesh becomes dry and powdery.

Preventive.-Destroy all affected tubers.

LeAf-Blight (Phyllosticta bataticola, E. \& M.).-Produces white, dead patches upon the leaves.

Remedy.-Spray with some of the copper fungicides.

ScurF (Monilochctes infuscans, E. \& Hals.).-The whole surface of the potato becomes scurfy, and it causes the tuber to shrink.

Preventive.-Use only healthy potatoes for seed.

SoFT-Rot (Rhizopus nigricans, Ehr.).-The tubers rot with a soft and putrid decay. It is most destructive after the potatoes are stored.

Preventive.--Store in a well-ventilated, artificially warmed room, at a temperature of about $\% 0^{\circ}$. Store only sound and perfect tubers, and remove at once any which are attacked.

SoIL-RoT (Acrocystis batatas, E. \& Hals.).-The tubers are attacked when young, and the diseased portion ceases to grow, causing the potato to become constricted or variously contorted.

Preventive.-Rotation. It is probable that the sweet-potato cannot be grown again safely on infested soil for a number of years.

Stem-Rot, Black-Shank.-An obscure disease attacking the young shoots near the ground and the tops of the young 
Sweet-Potato (Stem-Rot), continued.

tubers, causing the tubers to rot away above, and to send up splouts below the injured portion.

Preventive.-Rotation. Heat the soil used for seed-bed.

White-Mold or LEAF-Mold (Cystopus Ipomøa-pandurance, Farl.)-The leaves become pale and brown patches appear, and small whitish patches occur on the under surface. It thrives upon the wild potato-vine or man-of-the-earth (Ipomoea pandurata).

Preventive.-Destroy the wild potato-vine upon which the fungus grows.

Remedy.-Some copper fungicide applied in a spray.

White-Rot.-This disease causes portions of the tuber to become white and chalk-like, and sometimes the whole tuber assumes a chalk-like consistency.

Preventive.-Use only healthy stock, and probably a rotation of crops will be useful.

Tomato. BLIGHT (Cladosporium fulvum, Cooke).-Soft brown irregular spots appear on the under surface of the leaves, and the upper surface becomes spotted with yellow. The leaves finally shrivel. Most serious in greenhouses.

Preventive.-In houses, keep the temperature as even as possible. In particular, avoid sudden changes.

Remedy.-Bordeaux mixture or arnmoniacal carbonate of copper sprayed on the plants every week or ten days.

Rot (Macrosporium tomato).-The rotting of the nearly grown or ripe fruit.

Preventive.-The small cherry and plum tomatoes are not attacked, and the old-fashioned angular sorts are comparatively free. Training the vines so as to give the fruit plenty of light and air is usually useful. Heavy applications of fresh stable-manure appear to augment the injury. Burn all infested vines and fruits in the autumn.

Remedy.-Spray with Bordeaux mixture.

The bacterial potato-blight or rot also attacks tomatoes. See under Potato.

Verbena. Rust (Oidium erysiphoides).-A rust which appears on the leaves, eventually destroying the plants.

Preventives.-Start with perfectly healthy and vigorous stock, and give good culture. In the house, endeavor to avoid drafts, but give plenty of air on bright days. 
Verbena (Rust), continued.

Remedy.-Sulphide of potassium sprayed upon the plants every few days.

Violet, Violet Disease or Rust (Peronospora Violoe, DeBary ?). -Appears on the leaves as small rounded black or brown spots, causing the leaf finally to wither and die.

Preventives.-It is supposed that any neglect or improper handling renders the plants more liable to the disease. Burn all infested plants, and do not use the same soil again for violets. Sprays of copper compounds.

Watermelon. Anthracnose or Pod-Rust.-See under Bean.

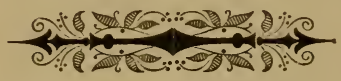

Inasmuch as the growth of one year determines the possibility of a crop in the succeeding year, it follows that judicious spraying, by keeping the foliage bealtby, must bring larger crops; and this secondary result of spraying is usually as important as the immediate result. There are failures and discouragements in spraying, but they are fewer than in most other borticultural operations even though the practice is yet comparatively new. 


\section{CHAPTER V.}

Injuries from Mice, Rabbits, Squirrels and Birds, with Preventives and Remedies.

To prevent mice from girdling trees in winter.-In heeling-in young trees in the fall, do not use straw or litter, in which mice can make their nests. In orchards, see that tall grass, corn-husks, or other dry material does not gather about the trees in fall. If danger from mice is apprehended, tramp the first snow firmly about the trees, in order to compact the grass and litter so that mice cannot find shelter. Where the paper-birch grows, it will be found a good plan to place sections of birch-bark from limbs or small trunks about the base of the tree. These sections roll up tightly about the tree, and yet expand so readily with the growth of the tree that they may be allowed to remain. Tie thin strips of wood, as laths or shingles, about the tree.

Washes to protect trees from mice.-Wash the trees with some persistent substance in which is placed Paris green. Maynard finds the following substances useful for holding the poison: Portland cement of the consistency of common paint; Portland cement 10 parts and gas-tar 1 part; Portland cement 10 parts and asphaltum 1 part; Portland cement 10 parts and Morrill's tree-ink 1 part.

Lime-wash, to which is added a little sulphur, tobacco-decoction, and soap-suds.

Carbonate of baryta for rats and mice.-Sugar and oatmeal or wheat flour, of each 6 ozs.; carbonate of baryta, $1 / 4 \mathrm{lb}$; oil of anise-seed, enough to give the mixture a pretty strong odor.

Tartar emetic fos rats and mice.-Tartar emetic, 1 part, oatmealor flour, 4 parts; beef or mutton suet enough to make all into a paste. 
Camphor for rats and mice.-Mix a few pieces of camphor with vegetable seeds, to preserve them.

French paste for rats and mice.-Oatmeal or wheat flour, $3 \mathrm{lb}$; powdered indigo, $1 / 2$ oz. ; finely powdered white arsenic, 4 ozs. ; oil of anise-seed, $1 / 2 \mathrm{drachm}$. Mix, and add of melted beef suet or mutton tallow $2 \frac{1}{2} \mathrm{lbs}$., and work the whole up into a paste.

Wash for keeping rabbits, sheep and mice away from trees.Fresh lime, slaked with soft water (old soap-suds are best); make the wash the thickness of fence or house wash. When 1 peck of lime is used, add when hot $\frac{1}{2}$ gallon crude carbolic acid, $1 / 2$ gallon gas-tar and 4 pounds of sulphur. Stir well. For summer wash leave gas-tar out, and add in place of it 1 gallon of soft soap. To keep rabbits and sheep from girdling, wash late in fall, or about the time of frost, as high as one can reach.

To remedy the injury done by mice and rabbits.-

1. Pare and clean the wound, and cover it thickly with fresh cow-dung, or soft clay, and bind it up thoroughly with a cloth. Grafting-wax bound on is also good. Complete girdling, when done late in spring-when settled weather is approaching-can be remedied in this manner.

2. Insert long scions over the wound, by paring them thin on both ends and placing one end under the bark on the upper edge of the wound and the other under the bark on the lower edge. Wax thoroughly the points of union, and tie a cloth band about the trees over both extremities of the scions.

Blood for rabbits. - Blood smeared upon trees, as high up as rabbits can reach, will keep them away.

To drive rabbits from orchards.-Dip rags in melted sulphur and then secure them to sticks which are stuck promiscuously through the orchard.

It should be an imperative rule with all orchardists not to allow brush heaps or piles of poles and rails to remain upon their premises if rabbits are troublesome in the neighborhood, for it is in such places that the animals live.

Wash to protect trees from rabbits. -Fresh cow-dung, 1 peck; quick-lime, $1 / 2$ peck; flowers of sulphur, $1 / 2$ pound: lampblack, $1 / 4$ pound. Mix the whole into a thick paint with urine and soap-suds. 
California rabbit-wash.-Commercial aloes, 1 pound to 4 gallons of water, both sprinkled on leaves and painted on the bark, gives a bitter taste, which repels rabits.

\section{California rabbit-poisons.-}

1. Pieces of watermelon, canteloupe, or other vegetables of which they are fond, may be poisoned with strychnine and then scattered around the orchard.

2. To 100 pounds of wheat take 9 gallons of water and 1 pound of phosphorus, 1 pound of sugar, and 1 ounce oil of rhodium. Heat the water to boiling point and let it stand all night. Next morning stir in flour sufficient to make a sort of paste. Scatter it about the place.

3. Another preparation is $1 / 2$ teaspoonful of powdered strychnine, 2 teaspoonfuls of fine salt, and 4 of granulated sugar. Put all in a tin box and shake well. Pour in small heaps on a board. It hardens into a solid mass. Rabbits lick it for the salt, and the sugar disguises the poison.

Sulphur for rabbits.-Equal proportions of sulphur, soot and lime, made into a thick paint with cow manure. Smear upon the trees.

Cow-manure for rabbits.-A mixture of lime, water and cowmanure, made strong, forms an excellent anti-rabbit composition.

Asafotida for rabbits. - A teaspoonful of tincture of asafoetida in $1 / 2$ pailful of liquid clay, mud, or muck of any kind. Apply with a brush to the stem and branches of young trees. Two or three applications during winter.

California ground-squirrel remedies.-Take 5 quarts of clean wheat; scald with water; drain. Take $2 / 8$ cup of white sugar, dissolve with sufficient water to make a syrup; add 1 ounce powdered strychnine, stir thoroughly until a thin paste is formed. Pour this on the damp wheat. Stir thoroughly for at least 15 minutes. Add 1 pint powdered sugar, stir; add 5 to 10 drops of rhodium and 5 to 10 drops of oil of anise-seed. Place a few grains in each squirrel-hole, putting it as far in as possible.

Bisulphide of carbon is also largely used. A small quantity is poured into the burrow, and the hole is immediately closed securely with dirt. 
California ground-squirrel remedies, continued.

Tying newspapers about trees in such manner as to allow the upper part of the paper to project loosely a few inches, frightens the squirrels away.

Poison for English sparrows.-Dissolve arseniate of soda in warm water at the rate of 1 ounce to 1 pint; pour this upon as much wheat as it will cover (in a vessel which can be closed so as to prevent evaporation), and allow it to soak for at least 24 hours. Dry the wheat so prepared, and it is ready for use. It should be distributed in winter in places where the sparrows congregate.

Bird-poisons.-

1. Place a shallow box on the end of a pole and put it 4 or 5 feet from the ground to keep the poison out of the way of domestic fowls. In the box sprinkle corn-meal and a very little strychnine, which mixture the birds eat. It will not hurt dogs or cats to eat the dead bird for the reason that there is not enough poison absorbed by the bird. (Californian).

2. Put the strychnine in pieces of apples and stick them on the ends of limbs of the trees. (Californian.)

To protect fruits from birds.-One of the best devices is mosquitobar spread over the bushes or trees. For bush-fruits and and small trees the expense is not great.

Have a taxidermist mount several hawks, and place them in natural positions in the trees or vines.

To protect newly planted seeds. Coat the seeds with red lead, by moistening the seeds slightly and stirring in red lead until all the seeds are thoroughly coated. Let the seeds dry for two or three hours before sowing.

To protect planted corn from crows.-Dip the kernels in coal-tar and then dust them with plaster.

$$
\therefore \quad \& \quad f
$$

The fatber of bumankind bimself ordains

The busbandman should tread no path of flowers, But waken the earth witb sleepless pains.

So pricketb be these indolent bearts of ours. 


\section{CHAPTER VI.}

\section{WeEds AND Moss.}

1. Weeds in general.-Weeds rarely trouble the good cultivator, particularly in regetable gardening. Intensive methods of cultivation allow no weeds to appear. It is economy, both in labor and returns from the crop, to prevent weeds from appearing, rather than to hoe or pull them out after they are partly grown and hare done some damage. Frequent light stirrings of the soil with cultivator, harrow or rake are the cheapest mode of weed destruction. In the struggle with weeds it is well to consider the longevity of the various species. Annual weeds, those which naturally die after the season's growth, require no special treatment. Biennial species, those which die at the end of the second year, may be held in check by preventing them from seeding, as by mowing them when coming into flower. Examples of this class are the mullein, wild carrot and field or bull-thistle. Perennial species, those which live indefinitely, often require particular treatment. Some of the worst perennial species are Canada thistle, white or ox-eye daisy, toad-flax, live-forever, docks, and various grasses. Very frequent, persistent and thorough cultivation will destroy any of these. Cultiration should be repeated even before the weeds recover sufficiently to take root again. Seeding down and mowing the weeds with the hay will destroy most weeds. In dry and sandy soils three or four thorough plowings during the season will destroy Canada thistles and other pests, particularly in dry years, but on richer and retentive soils greater thoroughness must be practiced.

2. Weeds in lawns. - Weeds usually come up thickly in newly sown lawns. They are to be prevented by the use of commercial fertilizers or very clean manure and clean grass$\mathrm{R}-\mathbf{5}$ 
Weeds in Lawns, continued.

seed. Clean june-grass, or blue-grass, seed is usually best. Grass-seed should be sown very thickly-2 to 4 bu. to the acre-and annual weeds cannot persist long. Frequent mowings during summer will keep the weeds down, and most species will not survive the winter. In old lawns most perennial weeds can be kept down by frequent mowings with a good lawn-mower. Grass can stand more cutting than weeds. If mowing cannot be practiced often enough for this purpose, the weeds may be cut off below the surface with a long knife or spud, and the crowns are then readily pulled out. Or a little sulphuric acid-oil of vitrol-may be poured upon the crown of each plant.

3. Woeds on Walks. - Walks should be so made that weeds cannot grow in them. This can be done by making a deep stone foundation and filling between the stones with cinders, coal ashes, or other similar material. But when weeds become established they can be destroyed by the following methods:

Salt.-Hot brine (1 lb. of salt to 1 gal. of water), boiled in a kettle on wheels and dipped out into watering-pots. Brine is better than dry salt, because it leaves very little color upon the walk.

Lime AD SclPHCR.-10 gals. of water, $20 \mathrm{lbs}$. of quick-lime and 2 lbs. flowers of sulphur are boiled in an iron vessel. After settling, the clear part is dipped off and used when needed. Care must be taken, as it will destroy edgings.

OIL of Vitriol. -1 part oil of vitriol (sulphuric acid) to 30 parts of water. Apply with a watering-pot. Choose a clear evening after a hot day. Keep clear of the edgings. The pot should be well painted, or a wooden pail should be used.

Arsenite of Soda.-Place $1 \mathrm{lb}$. of powdered arsenic in 3 gals. of cold water, boil and keep stirring; then add 7 gals. of cold water and $2 \mathrm{lbs}$. of crushed soda; stir well while boiling. Apply in dry weather.

CARBolic AcID. - 1 oz. of carbolic acid to 1 gal. of water, sprinkled over the path from a common watering-pot. Will also destroy ants.

Coal-tar Coating.-Mix coal-tar with gravel to the consistency of mortar; spread over the path 1 to 2 in. thick; cover this with gravel, then roll and add another thin coating of gravel to finish. 
4. Moss on Walks and Lawns. - In damp and shady places, and also in sterile places, moss may appear on walks and lawns. If the conditions cannot be improved, the following treatments may be tried:

$1 \mathrm{lb}$. oil of vitriol (sulphuric acid) to $10 \mathrm{qts}$. of water. Wet the surface thoroughly, being careful not to sprinkle edgings or good sod.

In early spring, while the ground is soft, work it backwards and forwards, with a long-toothed rake, in order to bring the moss to the surface. Clear away the moss and leave the ground untouched for a fortnight. Early in March repeat the operation, and about the middle of that month apply a dressing of rich compost, which may consist of any old rubbish well decomposed, adding 1-6 of fresh lime. Mix with compost a few days before using. Ccrer the ground with the compost at the rate of 200 barrow-loads per acre, passing it through a $\frac{3 / 4}{\mathrm{in}}$. sieve, to save the trouble of rolling. Rake it evenly over the surface with a wooden rake, and when dry seed down. An English method.

5. Moss on Trees.-Moss on fruit-trees is usually an indication of lack of vigor. Cultivate and prune. Wash the trees with soap or lye washes. Scrape off the bark, exercising care not to expose the "quick," or the tender inner bark. A good scraper is made of a small and much-worn boe with the handle cut to about two feet long.

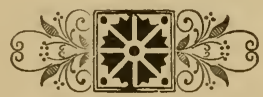

I went by the field of the slothful, and by the vineyard of the man void of understanding; and lo, it was all grown over with thorns, and nettles covered the face thereof, and the stone wall thereof was broken down.-Solomon. 


\section{CHAPTER VII.}

\section{Waxes for Grafting and for Wounds.}

\section{Common Resin and Beeswax Waxes.-}

1. Reliable Wax.-Resin, 4 parts by weight, beeswax, 2 parts, tallow, 1 part. Melt together and pour into a pail of cold water. Then grease the hands and pull the wax until it is nearly white. One of the best waxes.

2. Resin, 4 lbs.; beeswax, 1 lb. ; tallow, $1 \mathrm{lb}$.

3. Resin, 6 lbs.; beeswax, 2 lbs. ; linseed oil, 1 pt.

4. $6 \mathrm{lbs}$. resin, $1 \mathrm{lb}$. beeswax and 1 pt. linseed oil; apply hot with a brush, one-eighth of an inch thick over all the joints.

5. For Warm Weather:- 4 lbs. of resin, $1 \mathrm{lb}$. of beeswax, and from half to a pint of raw linseed oil; melt all together gradually, and turn into water and pull. The linseed oil should be entirely free from cotton-seed oil.

6. Resin, 6 parts; beeswax, 1 part; tallow, 1 part. To be used warm, in the house.

7. Resin, 4 or five parts; beeswax, $1 \frac{1}{2}$ to 2 parts; linseed oil, 1 to $1 \frac{1}{2}$ parts. For outdoor work.

2. Alcoholic Waxes.-

8. Lefort's Liquid Grafting Wax, or Alcoholic PlasTIC.-Best white resin, $1 \mathrm{lb}$; beef tallow, $1 \mathrm{oz}$; remove from the fire and add 8 ozs. of alcohol. Keep in closed bottles or cans.

9. Alcoholic Plastic with Beeswax. Melt 6 parts white resin with 1 part beeswax ; remove from stove and partially cool by stirring, then add gradually-with continued stirring-enough alcohol to make the mixture, when cool, of the consistency of porridge. In the temperature of the 


\section{Waxes for Grafting and for Wounds.}

Alcoholic Waxes (Alcoholic Plastic with Beeswax), continued.

grafting-room it will remain sufficiently plastic to permit applying to the cut surfaces with the finger.

10. Alcoholic Plastic with Tcrpentine.--Best white resin, 1 lb.; beef tallow, 1 oz.; turpentine, 1 teaspoonful; add enough alcohol (13 to 15 fluid ozs. of 95 per cent. alcohol) to make the wax of the consistency of honey. Or, less alcohol may be added if the wax is to be used with the fingers.

3. French and Pitch Waxes.-

11. Common Frexch. - Piteh, 1/2 lb.; beeswax, $1 / 2$ lb.; cow-dung, 1 lb. Boil together, melt and apply with a brush.

12. Common French Bandage Wax. - Equal parts of beeswax, turpentine and resin. While warm spread on strips of coarse cotton or strong paper.

13. Graftixg Chay. - $1 / 3$ cow-dung, free from straw, and $2 / 8$ clay, or clayey loam, with a little hair, like that used in plaster, to prevent its cracking. Beat and temper it for two or three days until it is thoroughly incorporated. When used it should be of such a consistency as to be easily put on and shaped with the hands.

14. 2 lbs. 12 ozs. of resin and 1 lb. 11 ozs. of Burgundy pitch. At the same time, melt 9 ozs. of tallow; pour the latter into the former, while both are hot, and stir the mixture thoroughly. Then add 18 ozs. of red ochre, dropping it in gradually and stirring the mixture at the same time.

15. Black pitch, 28 parts ; Burgundy pitch, 28 parts ; beeswax, 16 parts ; grease, 14 parts ; yellow ochre, 14 parts.

16. Black pitch, 28 lbs.; Burgundy pitch, 28 lbs.: yellow wax, 16 lbs.; suet or tallow, 14 lbs.; sifted ashes, 14 lbs. Whem used, warm sufficiently to malke it liquid.

17. Melt together $1 \frac{1}{4} \mathrm{lb}$. of clear resin and $3 / 4 \mathrm{lb}$. of white pitch. At the same time melt $1 / 4 \mathrm{lb}$. of tallow. Pour the melted tallow into the first mixture, and stir vigorously. Then, before the stuff cools, add, slowiy stirring meantime, $1 / 2 \mathrm{lb}$. of Venetian red. This may be used warm or cold.

4. Waxed String and Bandage.-

18. Waxed String For Root-grafting.-Into a kettle of melted wax place balls of No. 18 knitting-cotton. Turn the balls frequently, and in five minutes they will be thoroughly saturated, when they are dried and put away for future use. 
Waxed String and Bandage, continued.

This material is strong enough, and at the same time breaks so easily as not to injure the hands. Any of the resin and beeswax waxes may be used. When the string is used it should be warm enough to stick without tying.

19. Waxed Cloth.-Old calico or thin muslin is rolled on a stick and placed in melted wax. When saturated it is allowed to cool by being unrolled on a bench. It is then cut in strips to suit.

5. Waxes for Wounds.-

20 . Any of the more adhesive grafting-waxes are excellent for dressing wounds, although most of them cleave off after the first year. Stiff and ochreous paints are also good.

21. COAL-TAR.-Apply a coating of coal-tar to the wound, which has first been pared and smoothed. If the wound coutains a hole, plug it with seasoned wood.

22. Hoskins' WAx.-Boil pine-tar slowly for three or four hours; add $1 / 2 \mathrm{lb}$. of beeswax to a quart of the tar. Have ready some dry and finely sifted clay, and when the mixture of tar and wax is partly cold, stir into the above-named quantity about 12 ozs. of the clay; continue the stirring until the mixture is so stiff, and so nearly cool, that the clay will not settle. This is soft enough in mild weather to be casily applied with a knife or spatula.

23. Sch ffell's Healixg-Paint.-Boil linseed oil (free from cotton-seed oil) one hour, with an oz. of litharge to each pt. of oil; then stir in sifted wood-ashes until the paint is of the proper consistency. Pare the bark until smooth, as the fuzzy edge left by the saw will cause it to die back. Paint the wound over in dry weather, and if the wound is very large, cover with a gunny-sack.

24. TAR For BleEdiNg ix Vines.-Add to tar about 3 or 4 times its weight of powdered slate or some similar substance.

25. Hot Irox for Bleedixg Ix Tixes.-Apply a hot iron to the bare surface until it is charred, and then rub into the charred surface a paste made of newly-burnt lime and grease.

26. - Collodion for Bleedixg in Vixes. - In some extreme cases 2 or 3 coats will be needed, in which case allow the collodion to form a film before applying another coat. Pharmaceutical collodion is better than photographic. 


\section{CHAPTER VIII.}

\section{Cements, Mortars, Paints and Glues.}

\section{Cement and Mortar.-}

Cemexts for Iron.-1. Sal ammoniac, 2 ozs.; sulphur, $1 \mathrm{oz}$; clean iron-borings or filings reduced to powder, $12 \mathrm{lbs}$.; water enough to form a thin paste.

2. Sal ammoniac, 2 ozs.; iron-filings, 8 lbs.; sufficient water.

3. 1 or 2 parts of sal ammoniac to 100 of iron filings. When the work is required to set quickly, increase the sal ammoniac slightly and add a small amount of sulphur.

4. Iron-filings, $4 \mathrm{lbs}$.; pipe-clay, $2 \mathrm{lbs}$.; powdered potsherds, 11 lbs.; make into a paste with moderately strong brine.

5. Equal parts of red and white lead, mixed into a paste with boiled linseed oil. Used for making metallic joints of all kinds.

6. To 4 or 5 parts of clay, thoroughly dried and pulverized, add 2 parts of iron-filings, free from oxide, 1 part of peroxide of manganese, $1 / 2$ of sea salt and $1 / 2$ of borax; mix well, and reduce to a thick paste with water. Use immediately. Expose to warmth, gradually increasing almost to white heat.

7. Sifted coal-ashes, 2 parts, and common salt 1 part. Add water enough to make a paste and apply at once. This is also good for stoves and boilers, as it stands heat.

Boiler Cements.-1. Chalk, 60 parts; lime and salt, of each, 20 parts; sharp sand, 10 parts; blue or red clay and clean iron-filings, of each, 5 parts. Grind together and calcine or heat.

2. Powdered clay, $6 \mathrm{lbs}$; iron-filings, $1 \mathrm{lb}$. Make into a paste with linseed oil. 
Cement and Mortar (Boiler Cement), continued.

3. Powdered litharge, 2 parts; silver sand and slaked lime, of each, 1 part; boiled oil enough to form a paste.

These cements are used for stopping leaks and cracks in boiler's, iron pipes, stores, etc. They should be applied as soon as made.

Tar Cement.-Coal-tar, 1 part; powdered slate (slate flour), 3 or 4 parts; mix by stirring until thoroughly incorporated. Very useful for mending watering-pots, barrels, leaky sash, etc. It remains somewhat elastic. It does not adhere to greasy surfaces. It will keep for a long time before using.

Copper Cemext.-Beef blood thickened with sufficient finely powdered quick-lime to make it into a paste is used to secure the edges and rirets of copper boilers, kettles, etc. Use immediately.

Fireproof or Stone Cement.-Fine river sand, 20 parts ; litharge, 2 parts; quick-lime, 1 part; linseed oil enough to form a thick paste. Used for walls and broken stonework.

Earthenware Cement.-Grated cheese, 2 parts ; powdered quick-lime, 1 part; fresh white of egg enough to form a paste. Use as soon as possible.

For fine earthenware, liquid glue may be used.

Cement For Glass.-Methylated spirit sufficient to render liquid a half dozen pieces of gum-mastic the size of a large pea; in another bottle dissolve the same quantity of isinglass, which has been soaked in water and allowed to get surface dry, in 2 oz. of methylated spirits; when the first is dissolved add 2 pieces of either gum-galbanum or gum-ammoniac; apply gentle heat and stir; add the solution of isinglass, heat again and stir. Keep in a tightly stoppered bottle, and when used set in boiling water.

Sealing-Cemexts.-1. Beeswax, 1 1b. ; resin, 5 lbs. Stir in sufficient red ochre and Brunswick green, or lamp-black, to give the desired color.

2. Black pitch, 6 lbs.; ivory-black and whiting, of each, $1 \mathrm{lb}$. Less attractive than the former.

These are used for sealing up bottles, barrels, etc. 
Cements, Mortars, Paints and Glues.

Cement and Mortar, continued.

Mortar For Heavy RubBle-Work or Brick-Work.1 part of slaked lime, 2 parts of sand and $1 / 3$ part of blacksmith's ashes; for brick-work, 1 part of lime, 1 of sand and 1 of blacksmith's ashes.

Approximate Estimates of Mason-Work. $-3 \frac{1}{2}$ barrels of lime are required to cover 100 square yards plastering, two coats.

2 barrels of lime will cover 100 square yards plastering, one coat.

$1 \frac{1}{2}$ bushels of hair are needed for 100 square yards plastering.

$1 \frac{1}{4}$ yards good sand are required for 100 square yards of plastering.

$1 / 3$ barrel of plaster (stucco) will hard-finish 100 square yards plastering.

1 barrel of best lime will lay 1,000 bricks.

2 barrels of lime will lay one cord rubble-stone.

$1 / 2$ barrel of lime will lay 1 perch rubble-stone. (Estimating $1 / 4$ cord to perch.)

To every barrel of lime estimate about $5 / 8$-yard of good sand for plastering and brick-work.

2. Concrete, etc,, for Floors, Borders and Walks,-

Grodt FLoOR.-1. To secure a good grout or cement floor, make a good foundation of small stones or brickbats, and cover three or four inches thick with a thin mortar, made of 2 parts sharp sand and 1 part water-lime.

2. Fresh powdered lime, 2 parts; Portland cement, 1 part; gravel, broken stone, or brick, 6 parts. Mix with water to a liquid consistency, and let it be thrown forcibly, or dropped into its position. It should be well beaten or rammed to render it solid.

3. Equal parts of gravel, well screened, and clean river or pit sand. With 5 parts of sand and gravel, mix 1 part of Portland cement. Mix with water and apply 1 in. thick.

For Garden Borders.--Nine parts gravel and 1 part unslaked lime; slake the lime and cover it with gravel, then add water sufficient to make a very thin mortar. Apply 3 in. deep, allow it to stiffen a little, then roll. Finish with an inch thick of 1 part lime and 3 parts gravel. Apply soft. 
Concrete, etc., for Floors, Borders and Walks, continued.

For WALKs.-Walks should always have a well-made foundation of stones or brickbats to give hardness and in sure drainage. The top of the walk may be made of gravel, sifted coal-ashes, cinders from foundries, furnaces, etc. If gravel is used, care should be exercised to avoid the round or washed gravel, particularly that lying in the beds of streams, for it will not pack. One part of clean clay to 4 or 5 of gravel makes a good walk. Or the following may be used:

1. One part mineral pitch, 1 part resin, 7 parts chalk and 2 parts coar'se sand. Boil together, and lay it while in a hot state, adding a little gravel.

2. Boil for a short time 18 parts of mineral pitch and 18 parts of resin in an ilon kettle; then add 60 parts of coarse sand; mix well, and lay on the path to the thickness of $1 \mathrm{in}$.; then sift a little fine gravel over it, and beat it down before the cement sets.

3. Put down a coat of tar and sift some road-sand or coalashes over it very thickly. When this is dry repeat the operation until you have 4 coats of tar and as many of coal-ashes or road-sand.

4. Two parts of thoroughly dried sand, 1 part cinders, thoroughly dried. Mix together; then spread the sand and cinders on the ground and make a hole in the center, into which pour boiling hot tar and mix into a stiff paste; then spread on the walk, beat and roll.

5. Two parts lime rubbish and 1 part coal-ashes, both very dry and finely sifted; in the middle of the heap make a hole; into this pour boiling hot coal-tar; mix to a stiff mortar and spread on the ground 2 or 3 inches thick. The ground should be dry and beaten well. Cover with coarse sand; when cold, roll well.

3. Paints and Protective Compounds, -

Home-made Washes for Fexces and OUt-BUildings may be made by various combinations of lime and grease. The following are good formulas:

1. Slake fresh quick-lime in water, and thin it to a paste or paint with skim-milk. The addition of 2 or 3 handfuls of salt to a pail of the wash is beneficial 
Paints and Protective Compounds, continued.

2. 2 qts. skim-milk, 8 ozs. of fresh slaked lime, 6 ozs. of boiled linseed oil and $2 \mathrm{oz}$. of white pitch, dissolved in the oil by a gentle heat. The lime must be slaked in cold water and dried in the air until it falls into a fine powder; then mix with $1 / 4$ part of the milk, adding the mixed oil and pitch by degrees; add the remainder of the milk. Lastly, add 3 lbs. of the best whiting and mix the whole thoroughly.

3. Slake $1 / 2 \mathrm{bu}$. of lime in boiling water, keeping it covered; strain and add brine made by dissolving $1 \mathrm{pk}$. of salt in warm water, and $3 \mathrm{lbs}$. rice flour, then boil to a paste; add $1 / 2 \mathrm{lb}$. whiting and $1 \mathrm{lb}$. of glue dissolved in warm water. Mix and let stand for a few days before using.

Fire-Proof Paint.-In a covered vessel slake the best quick-lime, then add a mixture of skim-milk and water, and mix to the consistency of cream; then add $20 \mathrm{lbs}$. of alum, $15 \mathrm{lbs}$. of potash and $1 \mathrm{bu}$. of salt to every 100 gals. of the liquid. If white paint is desired, add to the above $6 \mathrm{lbs}$. of plaster of Paris.

For Dayp Walls. -1 . $3 / 4 \mathrm{lb}$. of hard soap to 1 gal. of water. Lay over the bricks steadily and carefully with a flat brush, so as not to form a froth or lather on the surface. After 24 hrs. mix $1 / 2 \mathrm{lb}$. of alum with 4 gals. of water; let it stand $24 \mathrm{hrs}$., and then apply it in the same manner over the coating of soap. Apply in dry weather.

2. $1 \frac{1}{2}$ lbs. resin, $1 \mathrm{lb}$. tallow, 1 qt. linseed oil. Melt together and apply hot, two coats.

Paint for Shading Greenhouse Roofs.-Make a paint of ordinary consistency of white lead and naphtha. It is removed from the glass by the use of a scrubbing-brush. Make it thin or it is hard to remove.

Ordinary lime whitewash is good for temporary use. If salt is added, it adheres better.

Water-Proofing Paints-For leather.-1. 1/2 lb. of shellic, broken into small pieces in a quart bottle; cover with methylated spirit, cork it tight, put it on a shelf in a warm place, and shake it well several times a day; then add a piece of camphor as large as a hen's egg; shake again and add $1 \mathrm{oz}$. of lamp-black. Apply with a small paint-brush.

2. Put into an earthen jar $1 / 4 \mathrm{lb}$. of beeswax, $1 / 2 \mathrm{pt}$. of neatsfoot oil, 3 or 4 tablespoonfuls of lamp-black, and a 
Paint and Protective Compounds, continued.

piece of camphor as large as a hen's egg. Melt over a slow fire. Have both grease and leather warm and apply with a brush.

3. 1 pt. of linseed oil, $1 / 2 \mathrm{lb}$. mutton suet, 6 ozs. of clean beeswax and 4 ozs. of resin; melt and mix well. Use while warm with a brush on new boots or shoes.

For Cloth for Pits axd Frames.-Old pale linseed oil, 3 pts.; sugar of lead (acetate of lead), 1 oz.; white resin, 4 ozs. Grind the acetate with a little of the oil, then add the rest and the resin. Use an iron kettle over a gentle fire. Apply with a brush, hot.

For PAPER.-Dissolve $18 / 4 \mathrm{lbs}$. of white soap in $1 \mathrm{qt}$. of water; in another qt. of water dissolve $1 \frac{1}{2} \mathrm{ozs}$. of gum arabic and 5 ozs. of glue. Mix the two liquids, warm them and soak the paper in it and pass through rollers, or simply hang it up to dry.

To Prevent Metals From Rusting.-Melt together 3 parts of lard and 1 part of powdered resin. A very thin coating applied with a brush will keep stores and grates from rusting during summer, even in damp situations. A little black lead can be mixedowith the lard. Does well on nearly all metals.

To Prevent Rusting of NaIls, Hinges, Etc.-1 pt. of linseed oil, 2 ozs. black lead; mix together. Heat nails redhot and dip them in.

Amodxt of Paint Required for a Given Surface.-It is impossible to give a rule that will apply in all cases, as the amount varies with the kind and thickness of the paint, the kind of wood or other material to which it is applied, the age of the surface, etc. The following is an approximate rule: Divide the number of square feet of surface by 200 . The result will be the number of gallons, of liquid paint required to gire two coats; or divide by 18 and the result will be the number of pounds of pure ground white-lead required to give three coats.

\section{Glues. -}

Liquid Glue.-1. Dissolve 2 lbs. of best pale glue in $1 \mathrm{qt}$. of water in a covered ressel, placed in a hot water bath; when cold, add to it 7 ozs. of commercial nitric acid. When cold put in bottles. 
Glues (Liquid Glue), continued.

2. Finest pale orange shellac, broken small, 4 ozs.; methylated spirit, $3 \mathrm{oz}$; put in a warm place in a closely corized bottle until dissolved. Should have the consistency of molasses. Or, borax $1 \mathrm{oz}$., water, $3 / 4 \mathrm{pt}$., shellac as before; boil in a closely covered kettle until dissolved; then evaporate until nearly as thick as molasses.

Flower GuM.-Very fine white shellac mixed with methylated spirit in a stone jar; shake well for $1 / 2$ an hour and place by a fire, and shake it frequently the first day. Keep in a cool place. Leave the camel's-hair brush in the gum. Never fill the brush too full and gum the petals close to the tube.

Gum for Labels and Specimens. - 1. Two parts of gum arabic, 1 part of brown sugar; dissolve in water to the consistency of cream.

2. Five parts of best glue soaked in 18 to 20 parts of water for a day, and to the liquid add 9 parts of sugar candy and 3 parts of gum arabic.

3. Good flour and glue, to which add linseed-oil, varnish and turpentine, $1 / 2 \mathrm{oz}$. each to the $1 \mathrm{~b}$. Good when labels are liable to get damp.

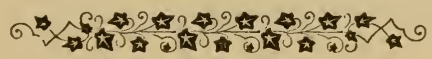

The increased love of home and the garden, in the older states, is a matter of every-day remark; and it is not a little curious that just in proportion to the intelligence and settled character of its population, is the amount of interest manifested in borticulture.†. J. DOWNING. 


\section{CHAPTER IX.}

\section{Seed Tables.}

\section{Quantity of Seed required to Sow an Acre.}

Asparagus . . . . . . . 4 or 5 lbs., or 1 oz. for $50 \mathrm{ft}$. of drill. Beans, Dwarf . . . . in drills. . . . . . 11/2 bu.

" Pole . . . . " . . . . . . . 10 to 12 qts.

Beet ........ "...... 5 to $6 \mathrm{lbs}$.

Buckwheat ..... " ....... 1 bu.

Cabbage ...... . in beds to transplant ... . 1/4 lb.

Carrot . . . . . . in drills . . . . . . . 3 to $4 \mathrm{lbs}$.

Cauliflower . . . . 1 oz. of seed for 1,000 plants .

Celery ....... 1 oz. for 2,000 plants ...

Corn ....... in hills....... 8 to 10 qts.

Cucumber ...... "...... . 2lbs.

Cress, Water .... in drills ........ 2 to $3 \mathrm{lbs}$.

" Upland ...." . ........2 to $3 \mathrm{lbs}$.

Egg-plant . . . . . 1 oz. of seed for 1,000 plants .

Kale, or Sprouts . . . . . . . . 3 to $4 \mathrm{lbs}$.

Lettuce . . . . . 1 oz. of seed for 1,000 plants .

Melon, Musk . . . . in hills ........ 2 to 3 lbs.

" Water ....." ........ 4 to 5 lbs.

Mustard ..... broadcast ...... . . . . . . $1 / 2 \mathrm{bu}$.

Onion . . . . . . in drills ...... 5 to $6 \mathrm{lbs}$.

" Seed for Sets .." . . . . . . $30 \mathrm{lbs}$.

" Sets ...... .......6 to $12 \mathrm{bu}$. .

Parsnip ...... ". ....... 4 to $6 \mathrm{lbs}$.

Peas............. 1 to 2 bu.

Botato (cut-tubers) . . . . . . . . 7 bu.

Pumpkin ..... in hills ...... 4 to 5 lbs. 
Quantity of Seed required to Sow an Acre, continued,

Radish ....... in drills ....... . 8 to $10 \mathrm{lbs}$. . . . . . . .

Sage .............. . . 8 to $10 \mathrm{lbs}$. . .

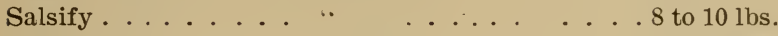

Spinage................ 10 to $12 \mathrm{lbs}$.

Squash, Bush .... in hills ........ 4 to $6 \mathrm{lbs}$.

" Running ... ......... 3 to $4 \mathrm{lbs}$.

Tomato ...... to transplant .... . . $1 / 4 \mathrm{lb}$.

Turnip ....... in drills ....... 1 to 2 lbs.

66 ..... broadcast ........ 3 to 4 lbs.

Grass (mixed lawn) .......... . . 2 to 4 bu.

\section{Weight and Size of Garden Seeds.}

Adapted from Vilmorin's Tables.

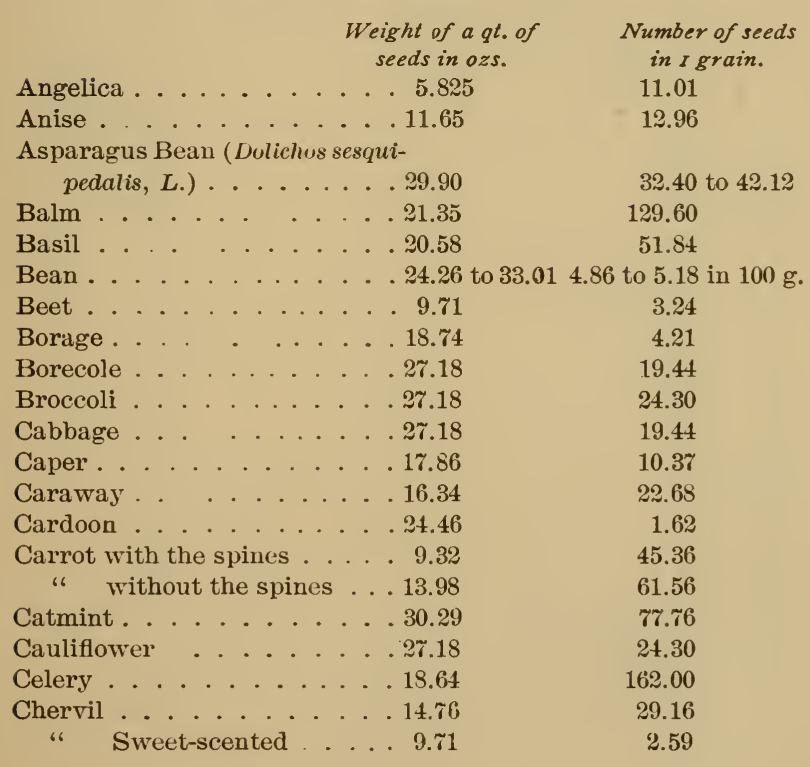


Weight and Size of Garjen Seeds, continued.

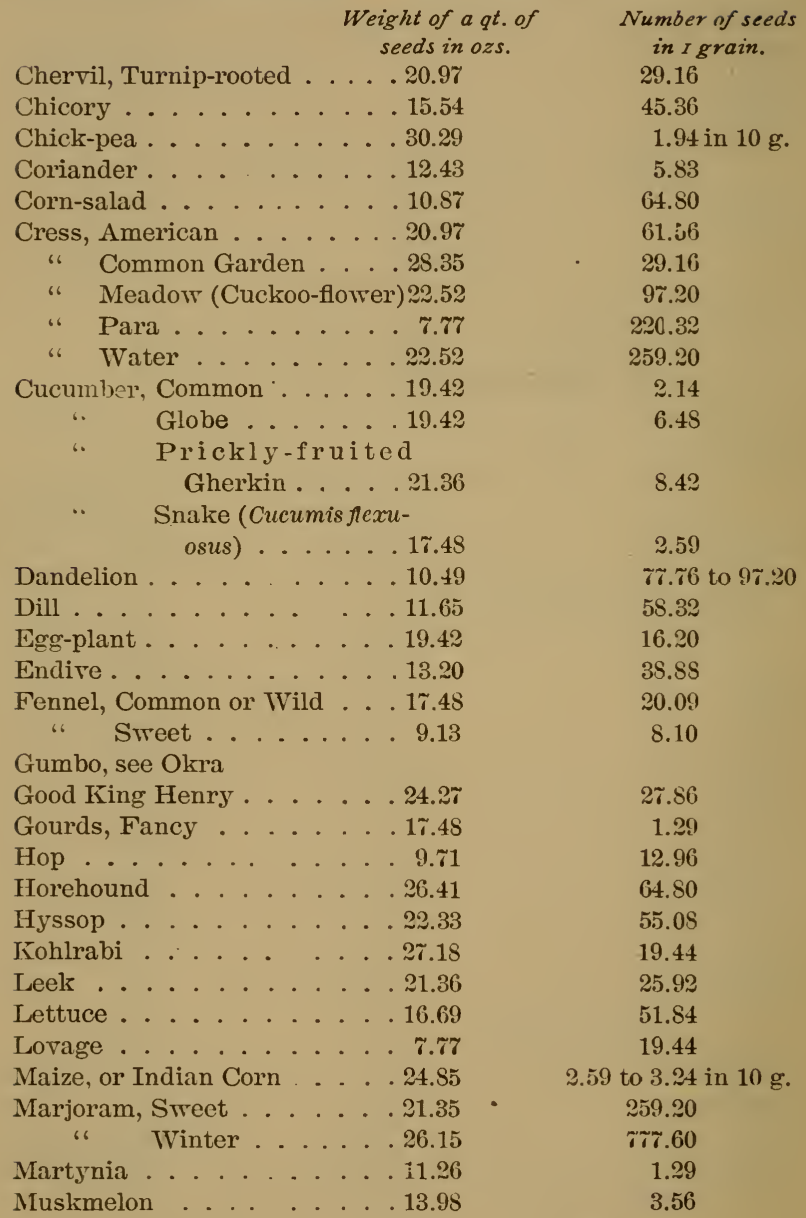


Weight and Size of Garden Seeds, continued.

Weight of a $q$ t. of seeds in ozs.

Mustard, Black or Brown . . . 26.15 " Chinese $\mathrm{Cabbage-}$ leaved ....2. 25.63 " White, or Salad . . 29.12 Nasturtium, Tall . . . . . 13.20 " Dwarf ..... 23.30

Okra ..............24.08

Onion ............ 19.42

Orach . . . . . . . . 5.44

Pea . . . . . . . . . 27.18 to 31.071 .29 to 3.56 in $10 \mathrm{~g}$. " Gray or Field . . . . . . 26.41 to 31.073 .24 to 5.18 in $10 \mathrm{~g}$.

Peanut.............5.53

Pepper . . . . . . . 17.48

Pumpkin ........ 9. 9. . .

Purslane . . . . . . . . . 23.69

Radish . . . . . . . . 27.18

Rampion . . . . . . . 31.07

Rhubarb . . . . . . 3.10 to 4.66

Rocket Salad . . . . . . 29.12

Rosemary . . . . . . . 15.54

Rue......... . . 22.52

Sage . . . . . . . . . . 21.36

Salsify . . . . . . . 8.93

Savory, Summer . . . . . . 19.42

" Winter.. . . 16.69

Scorzonera . . . . . . 10.09

Scurvy-grass . . . . . . 23.30

Sea-kale ....... . 8.16

Spinage, Prickly-seeded . . . . 14.56

“ Round-seeded . . . 19.80

“ New Zealand ..... 8.6\%

Squash, Bush-scallop . . . . 16.69

Strawberry . . . . . . . . 23.30

" Blite (Blitum) . . . 31.07

Tomato (Physalis) . 25.24

Sweet Cicely. . . . . . . 9. 9.1

Tansy ............. 11.65

Thyme......... . 26.41
Number of seeds in I grain.

45.36

42.12

12.96

4.54 to 5.18 in $10 \mathrm{~g}$.

9.7 in $10 \mathrm{~g}$.

9.7 to 11.66 in $10 \mathrm{~g}$.

16.20

16.20
1.29 to 1.94 in $10 \mathrm{~g}$.

9.72

1.94 in $10 \mathrm{~g}$.

162.00

7.77

1620.00

3.24

35.64

58.32

32.40

16.20

648

97.20

162.00

5.83

97.20 to 116.64

9.72 to 11.66 in $10 \mathrm{~g}$.

5.83

7.13

6.45 to 7.77 in $10 \mathrm{~g}$.

6.48

$51.8+$ to 162.00

324.00

64.80

2.59

453.60

388.80 
Weight and Size of Garden Seeds, continued.

Weight of a $q t$. of seeds in ozs.

Tomato........... 11.65

Turnip . . . . . . . . 26.02

Valerian, African . . . . . 4.27

Watermelon . . . . . 17.86

Wax Gourd ... . . . . 11.65

Welsh Onion, Common . . . . 18.64

" Early White. . 22.91

Wormwood .......25.24
Number of seeds

19.44 to 25.92

in $I$ grain.

29.16

16.20

3.24 to 3.88 in $10 \mathrm{~g}$.

1.36

19.44

32.40

745.20

\section{Number of Tree-Seeds in a Pound.}

FRUIT TREES.

About.

Apple ....................... 12,000

Cherry Pits ................... . . . 1,000

Peach ...................... . . . . 200

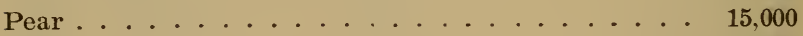

Plum .................. . . . . . 600

Quince.................... . . 15,000

Mulberry .................. 2. 200,000

FOREST TREES.

By count.

Butternut ........ Juglans cinerea ..... 15

Black Walnut . . . . . . Juglans nigra...... 25

American Horse-Chestnut . . Esculus glabra . . . . . 36

Hickory (Shell-Bark) . . . Carya alba . . . . . . 78

American Sweet Chestnut . . Castanea vesca . . . . 90

Silver-Leaved Maple . . . . Acer dascycarpum . . . 2,421

Honey-Locust . . . . . . . Gleditschia triacanthos . 2,496

Black Cherry . . . . . . Prunus serotina .... 4,311

Black Ash . . . . . . . Fraxinus sambucifolia . . 5,629

American Basswood . . . . Tilia Americana . . . 6, 6,337

Norway Maple . . . . . Acer platanoides . . . . 7,231

Sugar Maple . . . . . . . Acer saccharinum . . . 7,458

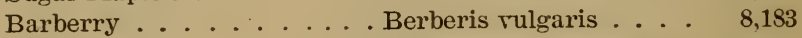

Red Cedar . . . . . . Juniperus Virginiana . . 8,321

Rock Elm . . . . . . . . . Ulmus racemosa . . . . 8,352

American White Ash . . . Fraxinus Americana. . . 9,858 
Number of Tree-Seeds in a Pound (Forest Trees), continuer.

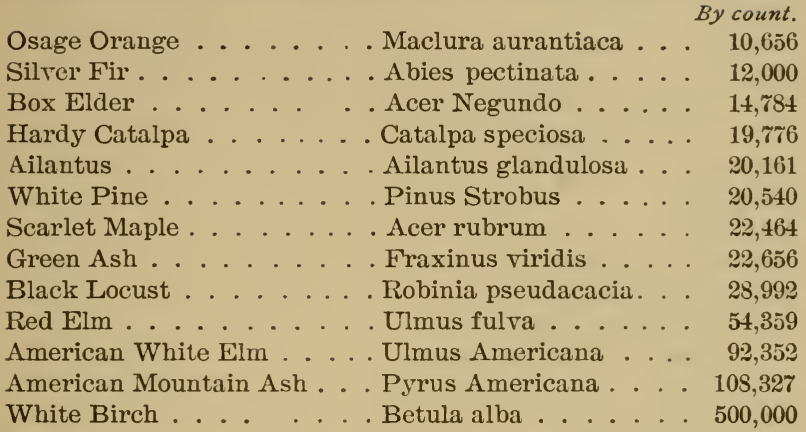

\section{Longevity of Garden Seeds.}

Adapted from Vilmorin's tables.

The number denotes that the seeds had not all lost their germinating power at the termination of the number of years recorded.

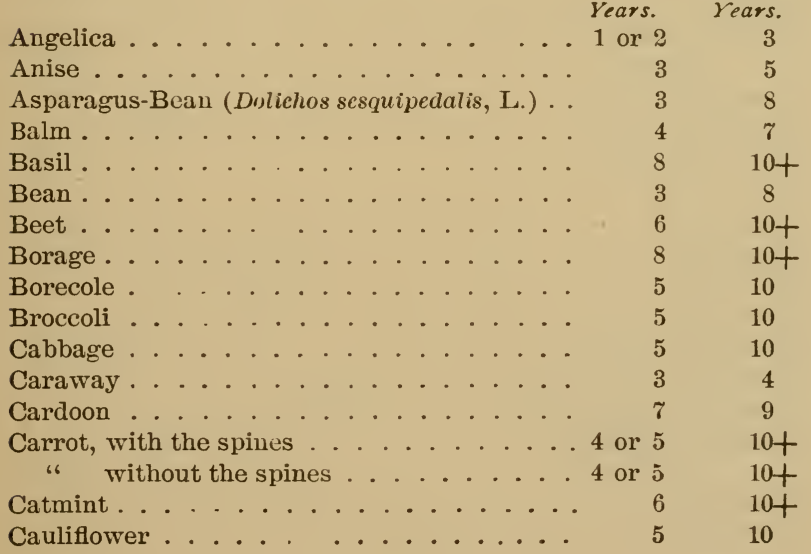


Longevity of Garden Seeds, continued.

Celery . . . . . . . . . . . . . 8

Average Extreme

Years. Years.

Chervil ................. 2 or 3

10

" Sweet-scented ......... . . 1

"Turnip-rooted ........... . 1

Chicory ................... 8

Chick-pea . . . . . . . . . . 3

Coriander................... 6

Corn-salad, Common . . . . . . . . . 5

Cress, American . . . . . . . . . . 3

" Common Garden . . . . . . . . . . 5

" Meadow (Cuckoo-flower) ....... 4

" Para.............. 5

"Water ............. 5

Cucumber, Common ......... 10

"

Globe

Prickly-fruited Gherkin . . . . . . 6

"

" Snake (Cucumis fexuosus) . . . . . T or 8

Dandelion

Dill ...................... 3

Egg-plant . . . . . . . . . . . . . 6

Endive . . . . . . . . . . . 10

Fennel, Common or Wild ......... . 4

Sweet

Gumbo, see Okra.

Good King Henry . . . . . . . . . . . . . 3

Gourds, Fancy . . . . . . . . . . . 6

Hop . . . . . . . . . . . . . 2

Horehound . . . . . . . . . . . 3

Hyssop . . . . . . . . . . . . . . 3

Kohl-rabi . . . . . . . . . . . . 5

Leek . . . . . . . . . . . . . 3

Lettuce, Common . . . . . . . . . . 5

Lovage ................. . . . . . . 3

Maize, or Indian Corn . . . . . . . . . . . . $\quad 2$

Marjoram, Sweet . . . . . . . . . . . $\quad 3$

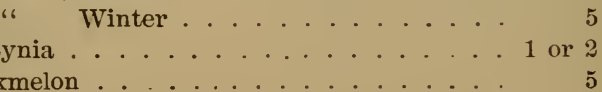

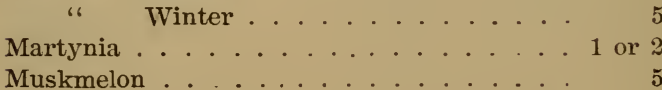

Muskmelon

5

$10+$

4

6

5

10

9

. 9

4

4

7

$\tau$

5 
Longevity of Garden Seeds, continued.

Mustard, Black or Brown

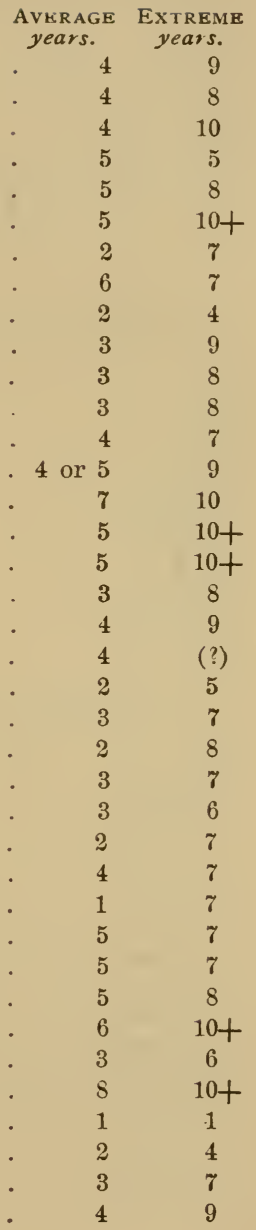

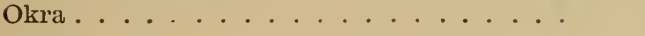

Onion

Chinese Cabbage-leared

" White or Salad

\section{5}

Nasturtium, Tall

$$
\text { Dwarf . }
$$

Orach

Parsnip

Parsley

Pea, Garden . . . . . . . . . . . . .

"Gray or Field . . . . . . . . . . . . 3

Pepper

Pumpkin

Purslane .

Radish .

Rampion .

Rhubarb

Rocket Salad

Rosemary .

Rue

Sage

Salsify

S

vimme

Winter

Scorzonera .

Scurvy-grass

Sea-Kale .

Spinage, Prickly-seeded

Round-seeded

“ New Zealand

Squash, Bush-scallop

Strawberry .

$$
\text { Tomato (Physalis) }
$$

Sweet Cicely

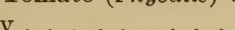

Tansy

Thyme

9 
Longevity of Garden Seeds, continued.

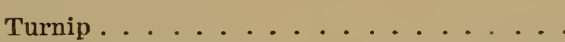

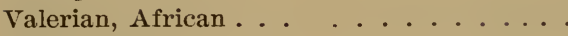

Average Extreme years. $y: a r s$.

Watermelon ..............

Wax Gourd ................. 10

Welsh Onion, Common ........ 2 or 3

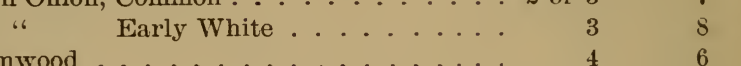

Wormwood

$\begin{array}{rc}5 & 10+ \\ 4 & 7 \\ 6 & 10 \\ 10 & 10+ \\ 3 & 7 \\ 3 & 8 \\ 4 & 6\end{array}$

\section{Average Time required for Garden Seeds to Germinate.}

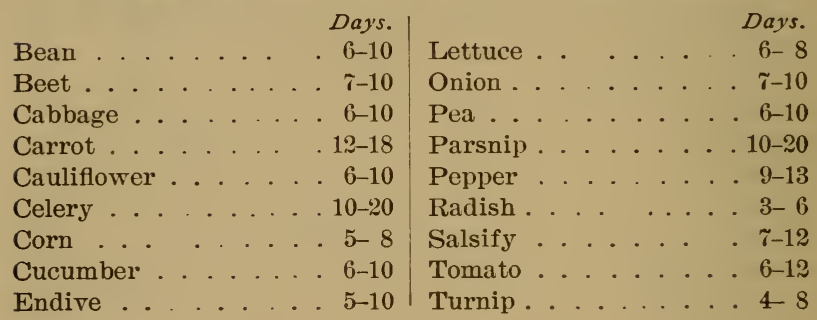

6. Proper Kinds and Quantities of Seeds for a Model English Kitchen Garden of I 1-4 Acres (Loudon).

Peas, 30 qts.; white cabbage of different kinds, 6 ozs; Saroy cabbage, $1 \frac{1}{2}$ ozs. ; Brussels sprouts, 2 ozs., cauliflower, 3 ozs. ; broccoli, 7 ozs. ; borecole, 2 ozs. ; red cabbage, 1 oz. ; kohl-rabi, 1 oz.; white turnip, 8 ozs.; yellow turnip, 2 ozs. ; early potatoes, 1 bu. ; carrots, 7 ozs. ; onions, 8 ozs. : broad beans, 6 qts. ; narrow beans, 3 qts.; kidney beans, 3 qts.; scarlet runner beans, 2 qts. ; celery, 3 ozs. ; Flanders spinach, 1 qt.; summer spinach, 2 qts.; Jerusalem artichoke, 1 pk. ; red beet, 4 ozs.; parsnips, 4 ozs.; leeks, 2 ozs.; garlic, 1/2lb.; shallots, 3 lbs.; salsify, 1/20z.; scorzonera, $1 / 2$ oz. ; cos lettuce, 5 ozs.; cabbage lettuce, 3 ozs. ; endive, 2 ozs. ; radish, 3 pts. ; cress, 1 pt. ; mustard, 1 qt. ; parsley, 2 ozs. 


\title{
CHAPTER X.
}

\author{
Planting-Tables.
}

1. Dates for Sowing or Setting Kitchen-Garden Vegetables in Different Latitudes.

Lansing, Michigan.

Average of 4 and 5 years.

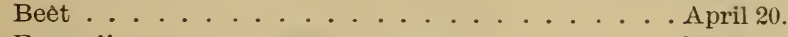

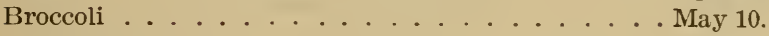

Brussels Sprouts . . . . . . . . . May 10.

. Cabbage, early, under glass . . . . . . . . March 15.

Cabbage, late . . . . . . . . . . . . May 20.

Carrot . . . . . . . . . . . May 7.

Cauliflower, under glass . . . . . . . . March 15.

Celery, under glass . . . . . . . . . . . March 18.

" in open ground . . . . . . . . May 20.

Corn . . . . . . . . . . . . May 19.

Cucumber . . . . . . . . . . . . . . . . . . . . . . . 23.

Egg-Plant, under glass . . . . . . . . . March 15 .

Kale . . . . . . . . . . . . . . May 9.

Kohlrabi . . . . . . . . . . May 9.

Lettuce . . . . . . . . . . . . May 5.

Melon . . . . . . . . . . . . May 30.

Okra . . . . . . . . . . . . . . May 15.

Onion . . . . . . . . . . . April 17 .

Parsnips . . . . . . . . . . . . May 7.

Pepper, under glass . . . . . . . . . . March 16.

Peas .................... April 15.

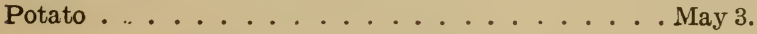


Dates for Sowing or Setting Vegetables, continued.

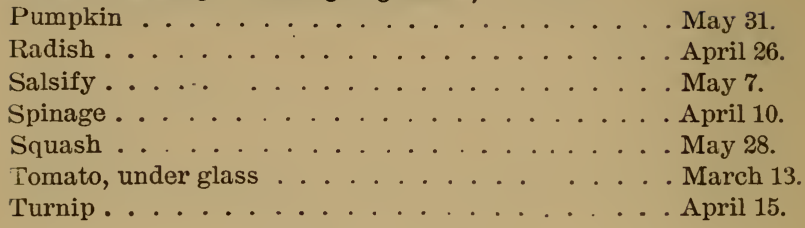

Boston. (RAwson.)

Asparagus . . . . A About the end of April.

Bean, Bush . . . . . About the first week in May.

Bean, Pole . . . . . . From about the middle of May to the 1st or June.

Bean, Lima . . . . . About the 1st of June.

Beet . . . . . . . About the middle of April.

Borecole, or Kale . . . About the middle of April; plant out in June.

Brussels Sprouts . . . In March or April in hotbed.

Cabbage . . . . . . Transplant the last week in April or the 1st in May.

Carrots . . . . . . Last of May or 1st of June.

Cauliflower ..... From the 1st of May until the 1st of July.

Celery ...... . The 1st week in April to the 2nd in July. Corn, Sweet . . . . . About the 1st of May.

Cucumber . . . . . For 1st crop, about the middle of March.

Egg-Plant . . . . . About March 15th in hotbed.

Endive . . . . . June or July.

Kohlrabi . . . . May or June.

Okra . . . . . . . About the 10th of May.

Peas . . . . . . During the last of April up to the 1st of May.

Pepper .. . . . . Put out of doors about the 1st of April.

Radish . . . . . . From the 1st of April to the middle of June.

Spinage . . . . About the 1st of September.

Tomato ....... About the 25th of May set plants outdoors.

Turnips, for fall use . . Any time from July 1st to August 20th. Watermelon ..... About the middle of May. 
Dates for Sowing or Setting Vegetables, continued.

New York. (HeNderson.)

Plants to sow from the middle of March to the end of April. Thermometer in the shade averaging 45 degrees.

$\begin{array}{lll}\text { Beet. } & \text { Cauliflower. } & \text { Parsley. } \\ \text { Carrot. } & \text { Endive. } & \text { Peas. } \\ \text { Cress. } & \text { Kale. } & \text { Radish. } \\ \text { Celery. } & \text { Lettuce. } & \text { Spinage. } \\ \text { Cabbage. } & \text { Onions. } & \text { Turnip. }\end{array}$

From the middle of May to the middle of June. Thermometer in the shade averaging 60 degrees.

$\begin{array}{lll}\text { Bean, Bush. } & \text { Bean, Runner. } & \text { Nasturtium. } \\ \text { Bean, Cranberry. } & \text { Corn, Sweet. } & \text { Okra. } \\ \text { Bean, Lima. } & \text { Cucumber. } & \text { Pumpkin. } \\ \text { Bean, Pole. } & \text { Melon, Musk. } & \text { Squash. } \\ \text { Bean, Scarlet. } & \text { Melon, Water. } & \text { Tomato. }\end{array}$

Georgia. (Oemler.)

Asparagus . . From December 1st to the middle of March.

Bean, Bush . . From the 1st to the middle of March.

Beet . . . . Through November and December.

Cabbage . . . From the 1st of October to the 15th. Transplant about Norember 1 st and later.

Cauliflower .. From May to September.

Cucumber. . . About March 1st to the 15th.

Egg-Plant. . . To prick out, about the middle of January, otherwise ten or fifteen days later.

Lettuce . . . A A bout the middle of September.

Onion ..... About January 1st.

Pea ...... About December 1st.

Potato ... . The 1st of February.

Radish . . . From Christmas to the last of February.

Spinage . . . . From September 10th until October 15 th.

Squash . . . About the last of February up to the middle of March.

Sweet-Potato . . In coldframes, about the 1st of January.

Tomato .... About January 1st.

Watermelon . About the 15th of March. 


\section{Tender and $\mathbf{H a r d y}$ Vegetables.}

Vegetables injured by a slight frost, and which should therefore be planted only after the weather has settled
All Beans.
Egg-Plant.
Pumpkin.
Corn.
All Melons.
Squash.
Cucumber.
Okra.
Pepper.
Tomato.
Vegetables which, when properly handled, will endure a frost.

$\begin{array}{lll}\text { Asparagus. } & \text { Corn Salad. } & \text { Parsley. } \\ \text { Beet. } & \text { Cress. } & \text { Parsnip. } \\ \text { Borecole. } & \text { Endive. } & \text { Pea. } \\ \text { Broccoli. } & \text { Horseradish. } & \text { Radish. } \\ \text { Brussels Sprouts. } & \text { Kale. } & \text { Rhubarb. } \\ \text { Cabbage. } & \text { Kohlrabi. } & \text { Salsify. } \\ \text { Carrot. } & \text { Leek. } & \text { Sea-Kale. } \\ \text { Cauliflower. } & \text { Lettuce. } & \text { Spinage. } \\ \text { Celery. } & \text { All Onions. } & \text { Turnip. }\end{array}$

Sweet-Potato.

\section{Usual Distances Apart for Planting Fruits.}

Apples ........... . . 30 to 40 feet each way

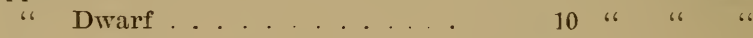

Pears ... . . . . . . . . . 20 " 30 " 30 " "

" Dwarf . . . . . . . . . 10 " 12 " " " "

Plums . . . . . . . . . . . . 16 " 20 " " " " " "

Peaches . . . . . . . . . . . 16 " 20 " " " "

Cherries ............ . . 16 " 16 " 25 " " " "

Apricots ............. . 16 " 20 " " " "

Nectarines ... . . . . . . . . 16 " 20 " " " " " " " "

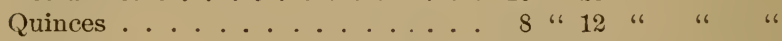

Grapes . . . . . . . . . . . . 8 " 812 " " " . "

Currants .......... $4 \times 5$ feet.

Gooseberries .......... $4 \times 5$ ".

Raspberries, Black ... . . . . $3 \times 6$ "

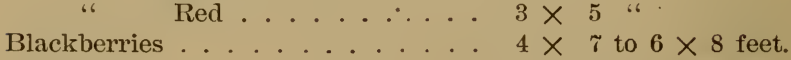

Cranberries . . . . . . . . 1 or $2 \mathrm{ft}$.apart each way.

Strawberries ......... $1 \times 3$ or 4 feet.

Oranges and Lemons . . . . . . . . 25 to 30 feet each way.

Figs . . . . . . . . . . . 20 " 25 " " " 
Usual Distances Apart for Planting Fruits, continued.

Mulberries .......... 25 to 30 feet each way. Japanese Persimmoris . . . . . . . . 20 " 25 " " 25 " "

Loquats . . . . . . . . . . . . 15 " 25 " " " "

Pecans . . . . . . . . . . . . 35 " 40 " " 40

Distances Recommended for Orange Trees in Calfornia.

Dwarfs, as Tangerines . . . . . 10 to 12 feet.

Half-Dwarfs, as Washington Navel . . 24 " 30 "

Mediterranean Sweet, Maltese Blood,

Valencia ........... 24 " 30 "

St. Michael ........... . . 18 " 24 " . . . .

Seedlings ... . . . . . . . 30 " 40 "

\section{Usual Distances Apart for Planting Vegetables.}

Artichoke . . . Rows 3 or $4 \mathrm{ft}$. apart, 2 to $3 \mathrm{ft}$. apart in the row.

Asparagus . . . Rows 3 to $4 \mathrm{ft}$. apart, 1 to $2 \mathrm{ft}$. apart in the row.

Beans, Bush . . . $1 \mathrm{ft}$. apart in rows 2 to $3 \mathrm{ft}$. apart.

" Pole.... . 3 to $4 \mathrm{ft}$. each way.

Beet, early . . . . In drills 12 to 18 in. apart.

" late.... In drills 2 to $3 \mathrm{ft}$. apart.

Broccoli . . . 1 1 $1 / 2 \times 2 \frac{1}{2} \mathrm{ft}$. to $2 \times 3 \mathrm{ft}$.

Cabbage, early . . . $16 \times 28$ in. to $18 \times 30$ in.

" late. . . $2 \times 3 \mathrm{ft}$. to $2 \frac{1}{2} \times 3 \frac{1}{2} \mathrm{ft}$.

Carrot ....... In drills 1 to $2 \mathrm{ft}$. apart.

Cauliflower ....2 $2 \times 2 \mathrm{ft}$. to $2 \times 3 \mathrm{ft}$.

Celery . . . . . Rows 3 to $4 \mathrm{ft}$. apart, 6 to $9 \mathrm{in}$. in the row.

Corn-Salad .... In drills 12 to 18 in. apart.

Corn, Sweet . . . Rows 3 to $3 \frac{1}{2} \mathrm{ft}$. apart, $9 \mathrm{in}$. to $2 \mathrm{ft}$. in the row.

Cress . . . . . . In drills 10 to 12 in. apart.

Cucumber .... 4 to $5 \mathrm{ft}$. each way.

Egg-Plant . . . $3 \times 3 \mathrm{ft}$.

Endive ...... $1 \times 1 \mathrm{ft}$. to $1 \times 1 \frac{1}{2} \mathrm{ft}$.

Horse-radish .... $1 \times 2$ or $3 \mathrm{ft}$.

Kohlrabi . . . $10 \times 18$ in. to $1 \times 2 \mathrm{ft}$.

Leek ...... 6 in. $\times 1$ or $1 \frac{1}{2} \mathrm{ft}$.

Lettuce . . . . . $1 \times 1 \times 1 / 2$ or $2 \mathrm{ft}$. 
Usual Distances Apart for Planting Vegetables, continued.

Melons, Musk .. 5 to $6 \mathrm{ft}$. each way.

"Water.. $\%$ to $8 \mathrm{ft}$. each way.

Mushroom .... 6 to 8 in. each way.

Okra ...... $1 \frac{1}{2} \times 2$ or $3 \mathrm{ft}$.

Onion ..... In drills from 14 to 20 in. apart.

Parsley . . . . . In drills 1 or $2 \mathrm{ft}$. apart.

Parsnip . . . . . In drills, 18 in. to $3 \mathrm{ft}$. a part.

Peas . . . . . . In drills; early kinds, usually in double rows,

6 to 9 in. apart; late kinds, in single rows.

2 to $3 \mathrm{ft}$. apart.

Pepper ..... 15 to 18 in. $\times 2$ to $21 / 2 \mathrm{ft}$.

Potato ..... 10 to 18 in. $\times 2 \frac{1}{2}$ to $3 \mathrm{ft}$.

Pumpkin .... 8 to $10 \mathrm{ft}$. each way.

Radish ...... In drills, 10 to 15 in. apart.

Rhubarb ....2 2 to $4 \mathrm{ft}$. $\times 4 \mathrm{ft}$.

Salsify . . . . . In drills, $1 \frac{1}{2}$ to $2 \mathrm{ft}$. apart.

Sea-Kale .... $2 \times 2$ to $3 \mathrm{ft}$.

Spinage . . . . . In drills, 12 to 18 in. apart.

Squash, Bush . . 3 to $4 \mathrm{ft}$. $\times 4 \mathrm{ft}$.

" Late...6 to $\mathrm{S} \mathrm{ft}$. each way.

Sweet-Potato. . . $2 \mathrm{ft} . \times 3$ to $4 \mathrm{ft}$.

Tomato..... $4 \mathrm{ft}$. $\times 4$ to $5 \mathrm{ft}$.

Turnip . .... In drills, $1 \frac{1}{2}$ to $2 \frac{1}{2} \mathrm{ft}$. a part.

\section{Number of Plants Required to Set an Acre of Ground at Given Distances.}

\section{Plants.}

Plants.

\begin{tabular}{|c|c|c|c|c|c|c|c|c|c|c|c|c|c|c|}
\hline & in. & & in. & & - & . $6,272,640$ & & & $x$ & & & & & \\
\hline & 66 & $x$ & 66 & - & - & . $3,136,320$ & $\sim$ & 66 & $x$ & “6 & & . & &, 440 \\
\hline & 66 & $x$ & ، & & & $2,090,8 S 0$ & & 66 & $x$ & "6 & & & & 80 \\
\hline & 66 & 4 & 6 & . & . & $1,568,160$ & & "6 & $x$ & 66 & & . & . & \\
\hline & 66 & 5 & 6 & . & . & . 1,254,528 & & 66 & $x$ & .6 & & . & & \\
\hline & 66 & $x$ & 66 & . & $\cdot$ & . 1,04 כ & & "6 & $\tau$ & 6 & & . & & \\
\hline & 6 & $x$ & 66 & . & . & - $\$ 96,0$ & & 6 & $x$ & " & & 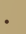 & & 40 \\
\hline & " & S & 66 & . & & 784,0 & & “6 & $\times 9$ & "6 & & . & . . & 480 \\
\hline & 6 & 9 & "6 & . & & 696,960 & & ، & $\times 10$ & 6 & & 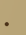 & . & 313,632 \\
\hline & 66 & $\times 10$ & 66 & . & & 627,269 & & “6 & & 66 & $\dot{0}$ & . & & 285,120 \\
\hline & 6" & $\times 11$ & 66 & . & & $5 \% 0,240$ & & “6 & & “ & - & . & & 261,360 \\
\hline & 66 & $<12$ & 6 & & & 522,720 & & 66 & $\times 3$ & 6 & & . & - . & 696,960 \\
\hline
\end{tabular}


Number of Plants to an Acre at Given Distances, continued.

\begin{tabular}{|c|c|c|c|c|c|c|c|c|c|c|c|c|c|}
\hline & in. $x$ & $1 \mathrm{in}$. & - & & - & $\begin{array}{l}\text { Plants. } \\
522, \approx 20\end{array}$ & $\tau$ in. & $\times 12$ & in. & - & & & $\begin{array}{l}\text { Plants. } \\
\tau 4,6 \tau 4\end{array}$ \\
\hline & . $x$ & 5 & & - & . & $415,1 \% 5$ & 84 & $\times s$ & 66 & . & . & & 95,010 \\
\hline & $x$ & $\because$ & - & - & . & 345 & 8 & $\times 9$ & 66 & . . & . & & \\
\hline & $x$ & $\because$ & . & . & . . & $29 \mathrm{~S}$ & “6 & $\times 10$ & 6 & . . & . & & \\
\hline & $x$ & .. & . & . & . . & 261 & 8 & $\times 11$ & 66 & . & . & & \\
\hline & $\times 9$ & $\therefore$ & . & . & . & 232 & S & $\times 12$ & 66 & . . & . . & & \\
\hline & $\times 10$ & “ & - & - & . & 209 & 9 & $\times 9$ & 66 & . & . & & \\
\hline & $\times 11$ & $1 \cdots$ & . & $\cdot$ & . & 190 & 9 & $\times 10$ & 66 & . & . & & \\
\hline & $\times 12$ & $\because$ & . & . & . . & 17 & 9 & $\times 11$ & 66 & . & . & & \\
\hline & $\times 4$ & " & . & . & . & 39 & 9 & $\times 12$ & 66 & . & . & & \\
\hline & $x$ & $\because$ & . & . & . & & 10 & $\times 10$ & 66 & . & . . & & \\
\hline & $x$ & .6 & . & . & . & 261 & 66 & $\times 12$ & 66 & . & . . & & \\
\hline & $x$ & . & . & . & . & 224 & 10 & $\times 15$ & 66 & . & . . & & \\
\hline & $x$ & “ & . & . & . & 196 & 10 & $\times 1$ & 66 & . & - & & \\
\hline & ${ }^{6} \times 9$ & " & . & . & . & 17 & 0 & 20 & 6 & . . & . . & & \\
\hline & $\because \times 10$ & 6 & . & . & . & $15 t$ & 10 & 4 & 66 & & & . & \\
\hline & $\cdots \times 11$ & $\cdot \cdot$ & . & . & . . & & 0 & 30 & 6 & . . & . . & . & \\
\hline & $\because \times 12$ & $\cdots$ & . & . & . . & & 0 & 36 & 66 & or 3 & $3 \mathrm{ft}$ & .. & \\
\hline & $\times 5$ & “" & . & . & . . & 250 & & & 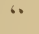 & . . & & 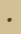 & \\
\hline & $6 \times$ & 6 & . & . & . & 209 & ". & & "6 & & $4 \mathrm{ft}$. & & \\
\hline & $6 \times \tau$ & 6 & . & . & . . & $1 \%$ & 66 & & 6 & . . & & & \\
\hline & $\times 8$ & $" 6$ & . & . & . . & & 66 & $\times 60$ & 66 & or 5 & $5 \mathrm{ft}$ & . & \\
\hline & $\times 9$ & $" 6$ & . & . & . . & & 66 & $\times 12$ & 66 & . & . . & $\cdot$ & \\
\hline & $6 \times 10$ & 6 & . & . & . & 125 & 6 & & 6 & - . & . . & . & \\
\hline & $" \times 11$ & 66 & · & . & . . & 11 & 66 & & 6 & . & & & \\
\hline & $\times 12$ & 66 & . & . & . . & & 12 & $\times 20$ & 6 & . & & & \\
\hline & $\times 6$ & 6 & . & . & . & & & & & & & & 21 \\
\hline & $\times 7$ & & 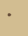 & . & . & & & & & & & & \\
\hline & $\times 8$ & 66 & & . & . & 130 & & & & & & & \\
\hline & $\times 9$ & ' & · & . . & . . & & 6 & & & or 3 & 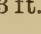 & 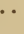 & \\
\hline & $\times 10$ & $"$ & . & . & . & & 66 & $\times 42$ & 6. & $\because$ & & & 12,446 \\
\hline & $\because \times 11$ & $" 6$ & . & . & . . & & $" 6$ & $\times 48$ & 66 & or 4 & $4 \mathrm{ft}$. & . & 10,890 \\
\hline & $\because \times 12$ & " & & . . & . . & & 6 & & $" ،$ & . . & & & \\
\hline & $\times 7$ & 66 & $\cdot$ & . & • & 12 & "6 & $\times 60$ & .6 & or 5 & $5 \mathrm{ft}$. & . & 8,712 \\
\hline & $\times 8$ & 66 & . & & . & & 6 & & 6 & . & & & 27,878 \\
\hline & $\times 9$ & "، & $\cdot$ & . & . & & 6 & $\times 18$ & "6 & . . & & & 232 \\
\hline & $" 6 \times 10$ & 6 & & . & . & & $"$ & $\times 20$ & $\because 6$ & . & & & 20,908 \\
\hline & $6 \times 11$ & 6 & & . & & 81,462 & $15 \quad "$ & $\times 24$ & $"$ & or 2 & $2 \mathrm{ft}$ & & 17,424 \\
\hline
\end{tabular}


Number of Plants to an Acre at Given Distances, continued.

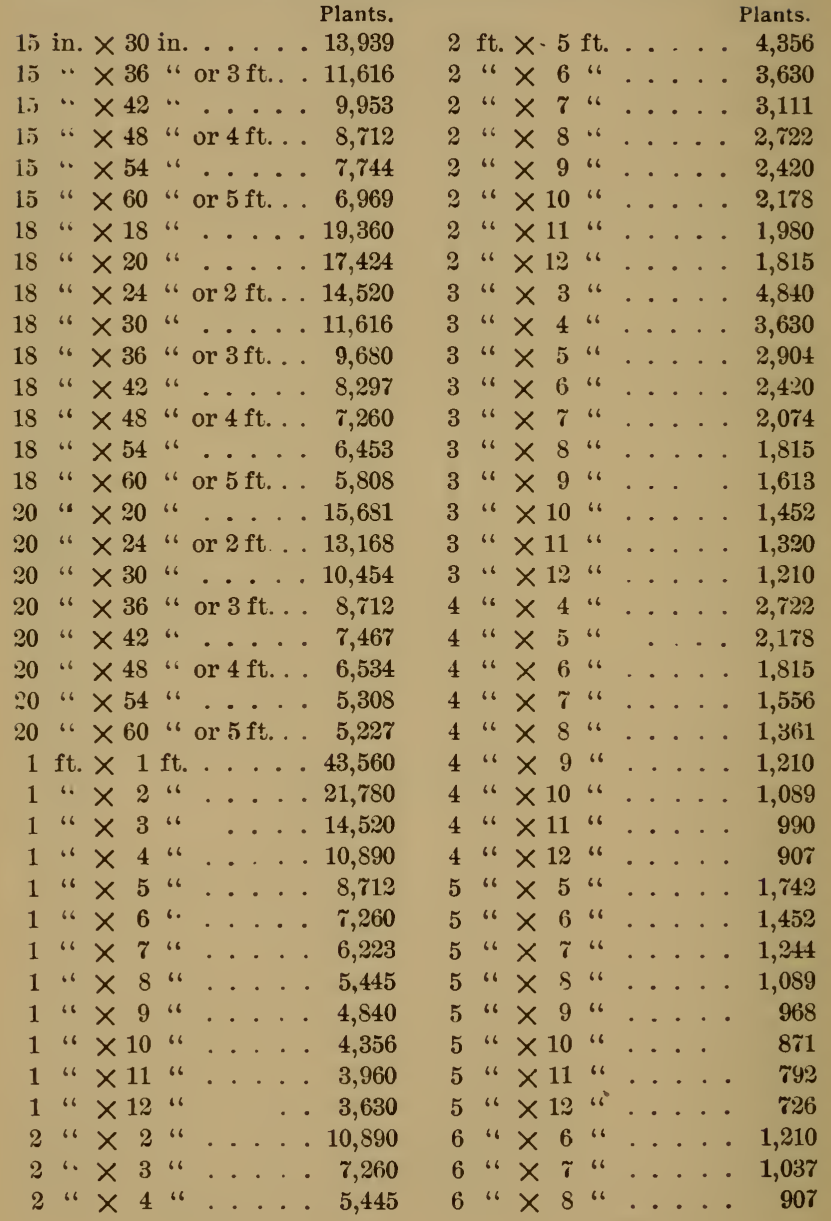


Number of Plants to an Acre at Given Distances, continued.

\begin{tabular}{|c|c|c|c|c|c|c|c|c|c|c|c|c|c|c|c|c|c|}
\hline 6 & ft. & & ft. & . • & . & . & • & 806 & 12 & ft. & $\times 18$ & ft. & . . & & & & $\begin{array}{r}\text { ants. } \\
201\end{array}$ \\
\hline (;) & 66 & $\times 10$ & 16 & . . & . & . & • & 726 & 12 & 6 & $\times 20$ & 66 & . . & & & & 181 \\
\hline (i & 66 & $\times 11$ & 66 & . . & . & . & . & 660 & 12 & 66 & $\times 24$ & 6 & & & & & 151 \\
\hline 6 & 66 & $\times 12$ & 66 & . . & . & . & . & 605 & 12 & 6 & $\times 30$ & $" 6$ & & . & & $\cdot$ & 121 \\
\hline ซ & 6 & $\times 7$ & 66 & . & . & . & . & 888 & 2 & 6 & $\times 36$ & 66 & & & & 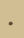 & 100 \\
\hline & .6 & $\times 8$ & 6 & . & . & . & • & ชช7 & 2 & 6 & $\times 42$ & 66 & & & & & 86 \\
\hline$\tilde{\tau}$ & 66 & $\times 9$ & 66 & . & . & . & . & 691 & 12 & 66 & $\times 45$ & 66 & & & & . & 75 \\
\hline 7 & ،6 & $\times 10$ & 66 & . & . & . & . & 622 & 12 & 66 & $\times 54$ & 66 & & . & & . & 67 \\
\hline$\tau$ & 66 & $\times 11$ & 16 & . & . & . & . & 565 & 2 & 6 & $\times 60$ & 66 & . & & & . & 60 \\
\hline 7 & 66 & $\times 12$ & 66 & . . & . & . & . & 51 & 15 & 66 & $\times 15$ & 66 & . & & & . & 93 \\
\hline 8 & 66 & $\times 8$ & 66 & . . & . & . & . & 680 & 15 & 66 & $\times 18$ & 66 & . & & & - & 161 \\
\hline 8 & 66 & $\times 9$ & 66 & . . & - . & . & . & 605 & 15 & 66 & $\times 20$ & 66 & . & & & . & 145 \\
\hline 8 & 66 & $\times 10$ & 66 & $\cdot$ & . & . & . & 544 & 15 & 6 & $\times 24$ & 6 & . & & & • & 121 \\
\hline$S$ & 66 & $\times 11$ & 6 & . . & . & . . & . & 495 & 15 & 6 & $\times 30$ & 6 & . & & . & & 96 \\
\hline 8 & "6 & $\times 12$ & 66 & . . & . . & . & . & 45 & 15 & 16 & $\times 36$ & 66 & . & . & . & & 80 \\
\hline 9 & 66 & $\times 9$ & .6 & . . & . & . & . & 537 & 15 & $\because 6$ & $\times 42$ & 66 & . & . & . & & 69 \\
\hline 9 & 66 & $\times 10$ & "6 & . & . & . & . & 451 & 15 & 66 & $\times 48$ & 6 & . & . & . & & 60 \\
\hline 9 & .6 & $\times 11$ & 66 & . . & . & - & . & 440 & 15 & 16 & $\times 54$ & 66 & . & . & . & & 53 \\
\hline 9 & 66 & $\times 12$ & 16 & . . & . & . . & . & 403 & 15 & 16 & $\times 60$ & 66 & . & . & 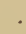 & & 45 \\
\hline 9 & "6 & $\times 14$ & 66 & . & . & . & . & 345 & 18 & 66 & $\times 18$ & 66 & . & . & . & & 34 \\
\hline 9 & 6 & $\times 15$ & 16 & . & . & . & . & 322 & 18 & 66 & $\times 20$ & 66 & . & • & 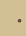 & & 121 \\
\hline 9 & 66 & $\times 18$ & 66 & . & . & - . & . & 268 & 18 & 66 & $\times 24$ & 66 & . & . & . & & 100 \\
\hline 9 & 66 & $\times 20$ & 66 & . & . . & . & . & 242 & 18 & 66 & $\times 30$ & 66 & . & . & . & & SO \\
\hline & 66 & $\times 10$ & 66 & . & . & . & . & & 18 & 6 & $\times 36$ & 6 & . & . & 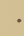 & & 67 \\
\hline 0 & 6 & $\times 12$ & 16 & . & . & . & . & 363 & 18 & 6 & $\times 42$ & 6 & . & . & 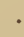 & & 57 \\
\hline 10 & 66 & $\times 15$ & 66 & . & . & . & . & 290 & 18 & 66 & $\times 48$ & 16 & . & . & 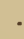 & & 50 \\
\hline 10 & 66 & $\times 18$ & 66 & . & . . & . & . & 242 & 18 & 66 & $\times 54$ & 66 & . & . & 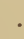 & & 44 \\
\hline 10 & 6 & $\times 20$ & 16 & . & . & . & . & 217 & 18 & 6 & $\times 60$ & 6 & . & • & 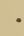 & & 40 \\
\hline 10 & 16 & $\times 24$ & 16 & . & . . & . & . & 181 & 20 & 6 & $\times 20$ & 16 & . & • & & & 108 \\
\hline 10 & 6 & $\times 30$ & 66 & . & . & . & . & 145 & 20 & 66 & $\times 24$ & 6. & . & • & 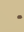 & & 90 \\
\hline 10 & 66 & $\times 36$ & 66 & . & . . & . & & 121 & 20 & 66 & $\times 30$ & .6 & . & • & & & 72 \\
\hline 10 & 66 & $\times 42$ & 6 & . & . . & . & • & 103 & 20 & 66 & $\times 36$ & $"$ & . & • & & & 60 \\
\hline 10 & 6 & $\times 45$ & 16 & . & & . & - & 96 & 20 & 66 & $\times 42$ & 6 & . & . & & & 51 \\
\hline 10 & 6 & $\times 48$ & " & . & - . & . & . & 90 & 20 & 66 & $\times 48$ & 66 & . & • & & & 45 \\
\hline 10 & 66 & $\times 54$ & 66 & . & . . & . & . & 80 & 20 & 66 & $\times 54$ & 66 & . & 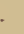 & & & 40 \\
\hline 10 & 66 & $\times 60$ & 66 & . & & . & . & 72 & 20 & 16 & $\times 60$ & 66 & . & 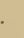 & & & 36 \\
\hline 12 & "، & $\times 12$ & 66 & . & & $\cdot$ & • & 302 & 24 & 6 & $\times 24$ & 6 & . & . & & & 75 \\
\hline 12 & 66 & $\times 15$ & 66 & . & . & . & & 242 & 24 & "6 & $\times 30$ & 16 & . & & & & 60 \\
\hline
\end{tabular}


Number of Plants to an Acre at Given Distances, continued.

Plants.

Plants.

$24 \mathrm{ft} . \times 36 \mathrm{ft} . \ldots . .50 \quad 40 \mathrm{ft} . \times 40 \mathrm{ft} . \ldots 27$

24 " $\times 42$ ".... 4340 ". $43 \times 42$ ".... 25

it " $\times 48$ " .... $37 \quad 40$ " 3748 ".... 22

24 " $\times 54$ ".... . 3340 " $\times 50$ "..... 21

24 " $\times 60$ " .... 3040 . $30 \times 54$ "..... 20

30 " $\times 30$ "..... $48 \quad 40$ " $4 \times 60$ ". . . . 18

30 " $\times 36$ " .... 4042 . 4042 ". . . . 24

30 " $\times 42$ ". . . . $34 \quad 42$ " $\times 48$ " . . . . 21

30 " $\times 48$ ". . . . $30 \quad 42$ " $\times 54$ " . . . . 19

30 " $\times 54$ ".... . 2642 " 2660 ". . . . 17

30 " $\times 60$ " ..... $24 \quad 48$. $24 \times 48$. . . . . 18

36 " $\times 36$ ".... . 3348 " $38 \times 54$ "..... 16

36 " $\times 42$ ".... 2848 " $28 \times 60$ "..... 15

36 " $\times 48$ ".... 2550 " 2550 ".... 17

36 " $\times 54$ " ..... 2250 " 2 . $\times 54$ w ..... 16

36 " $\times 60$ ".... . $20 \quad 50$ " 2060 "..... 14

38 " $\times 38$ " .... . $30 \quad 54$ " 3554 . .... 14

38 " $\times 40$. . . . 2854 " $28 \times 60$ ".... 13

38 " $\times 42$ " .... $27 \quad 60$ " $27 \times 60$ ". . . . 12

38 " $\times 48$ " .... $23 \quad 70$ " $23 \times 70$ "..... 8

38 " $\times 50$ " .... 2280 . $22 \times 80$ 6..... 6

38 " $\times 54$ "..... 2190 . $21 \times 90$ "... . 5

38 " $\times 60$ "..... 19100 . $19 \times 100$.... 4

To find the number of plants required to set an acre, multiply together the two distances, in feet, at which the trees stand apart, and divide 43,560 by the product; the quotient will be the number of plants required.

Quixcunx Plaxtixg.-To find the number of plants required to set an acre by the quincunx method, ascertain from the above tables the number required at the given rectangular distances, and then increase the number by one-half. 


\section{CHAPTER XI.}

Maturities, Yields and Multiplication.

1. Time Required for Maturity of Different Garden Crops, Reckoned from the Sowing of the Seeds.

Beans, String . . . . . . . . . 45- 65 days from seed.

" Shell ...... . . . . 65- 60 " " " "

Beets, Turnip . . . . . . . . . . . 65 " . 6 "

" Long Blood ........ . . 150

Cabbage, Early . . . . . . . . . . 105

" Late......... . . 150

Cauliflower ........... . 110

Corn . . . . . . . . . . 75

Egg-Plant . . . . . . . . . 150-160

Lettuce . . . . . . . . . . 65

Melon, Water . . . . . . . 120-120

" Musk . . . . . . . . . 120-140

Onion . . . . . . . . . . 135-150

Pepper . . . . . . . . . 140-150

Radish ........... . . 30- 45

Squash, Summer . . . . . . 60-65

" Winter ........... 125

$6 \quad 66 \quad 66$

Tomatoes . . . . . . . . 150

Turnips ............ 60- 10

$66 \quad 66 \quad 66$

$66 \quad 66 \quad 66$

$66.66 \quad 66$

$66 \quad 66 \quad 66$

$66 \quad 66 \quad 66$

$66 \quad 66 \quad 66$

$66 \quad 66 \quad 66$

$16 \quad 66 \quad 66$

$640 \quad 6$

$66 \quad 66 \quad 66$

66969

$66 \quad 66 \quad 66$

2. Time Required, from Setting, for Fruit-Plants to Bear.

Apple-3 years. Good crop in about 10 years.

Blackberry-1 year. Good crops in 2 and 3 years.

Citrus fruits (oranges, lemons, etc.) -2 to 3 years. Good crop in 2 or 3 years later.

Cranberry-3 years gives a fair crop.

Currant-1 year. Good crops in 2 and 3 years. 
Time Required, from Setting, for Fruit-Plants to Bear, continued.

Gooseberry-1 year. Good crops in 2 and 3 years.

Grape-Fair crop in 4 years.

Peach-2 years. Good crop in 4 years.

Pear -3 or 4 years. Fair crop in 6 to 12 years.

Persimmon, or Kaki-1 to 3 years.

Quince-2 years. Good crop in 4 years.

Raspberry-1 year. Good crop in 2 and 3 years.

Plum-3 years. Good crop in 5 or 6 years.

Strawberry-1 year. Heaviest crop usually in 2 years.

\section{Average Profitable Longevity of Fruit-Plants under High Culture.}

Apple . . . . . 25-40 years. Pear . . . . . .50-75 years. Blackberry . . . 8-12 " 4 Persimmon, or Kaki, as long Currant . . . . . 20 " 20 as an apple tree.

Gooseberry . . . 20 " Plum ... . 20-25 years.

Orange and Lemon, 50 or more. Raspberry . . . . 8-12 "

Peach . . . . . 8-12 years. Strawberry . . . . . 3 “

\section{Average Vields Per Acre of Various Crops.}

The yields of those crops in which the salable products are equal in number to the number of plants per acre, and in which the product is sold by the piece, are to be calculated from the planting-tables in Chapter X.-such as cabbage, celery, and the like.

Apples-A tree 20 to 30 years old may be expected to yield from 25 to 40 bus. every alternate year.

Artichoke-200 to 300 bus.

Beans, Green or Snap-75 to 120 bus.

" Lima- 75 to 100 bus. of dry beans.

Beet -400 to $\tau 00$ bus.

Carrots -400 to $\approx 00$ bus.

Corn -50 to 75 bus., shelled.

Cranberry-100 to 300 bus. 900 bus. have been reported.

Cucumber-About 150,000 fruits per acre.

Currant-100 bus.

Egg-Plant-1 or 2 large fruits to the plant for the large sorts like New York Purple, and from 3 to 8 fruits for the smaller raricties. 
Average Yields Per Acre of Various Crops, continued.

Gooseberry-100 bus.

Grape -3 to 5 tons. Good raisin vineyards in California, 15 years old, will produce from 10 to 12 tons.

Horse-radish -3 to 5 tons.

Kohlrabi-500 to 1000 bus.

Onion, from seed -300 to 800 bus. 600 bus. is a large average yield.

Parsnips-500 to 800 bus.

Pea, green, in pod-100 to 150 bus.

Peach-In full bearing, a peach tree should produce from 5 to 10 bus.

Pear-A tree 20 to 25 years old should give from 25 to 45 bus.

Pepper-30,000 to 50,000 fruits.

Plum -5 to 8 bus. may be considered an average crop for an a rerage tree.

Potato-100 to 300 bus.

Quince-200 to 400 bus.

Raspberry and Blackberry-50 to 100 bus.

Salsify-200 to 300 bus.

Spinage-200 barrels.

Strawberry-75 to 250 or even 300 bus.

Tomato -8 to 16 tons.

Turnip-600 to 1000 bus. 


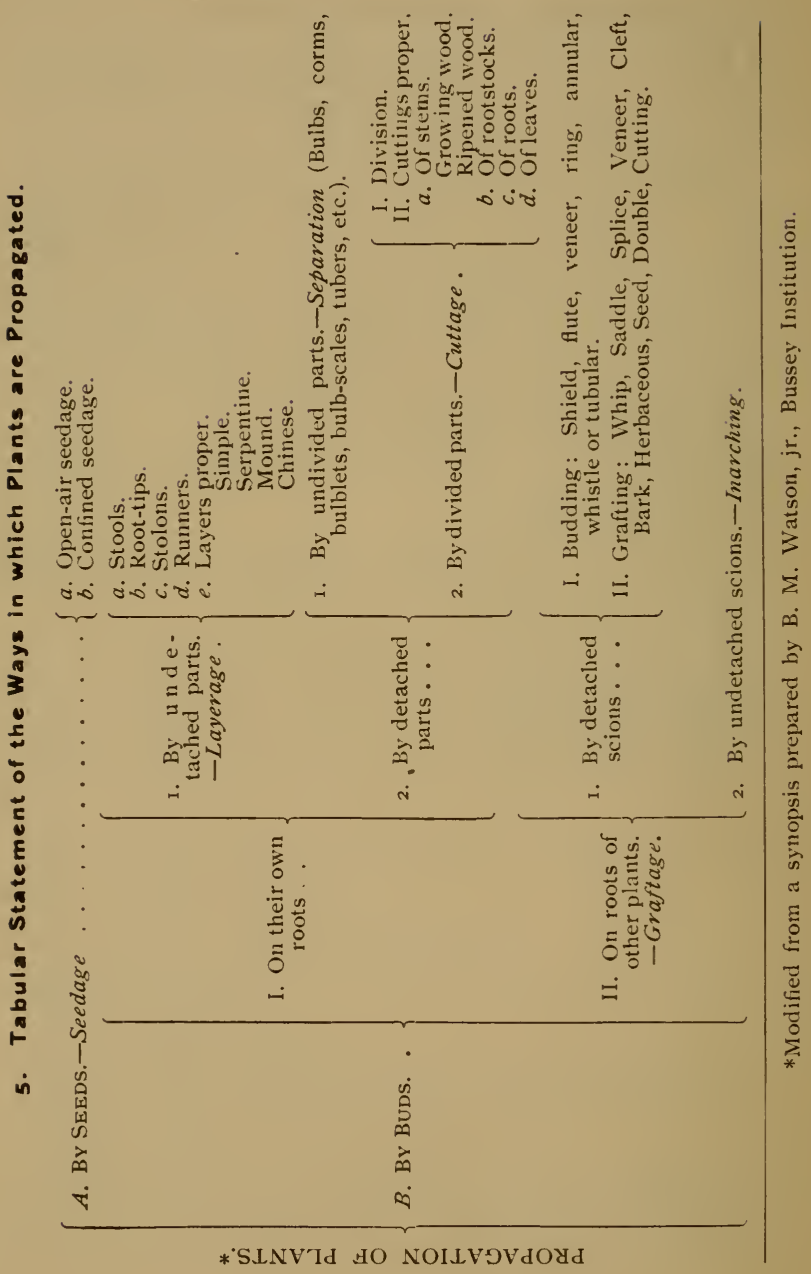




\section{Ways of Grafting and Budding. (Baltet.)}

\section{Grafting with Undetached Scions. (Inarching.)}

1.-Method by veneering.

" " inlaying.

English method.

2.-Inarching with an eye.

" " a branch.

Graftixg with Detached Scions.

1.-Side-grafting under the bark.

" " with a simple branch.

" " " with a heeled branch.

" " $"$ in the alburnum.

" " w with a straight cleft.

2.-Crown-grafting. with an oblique cleft.

Ordinary method.

Improved Method.

3.-Grafting de precision.

Veneering, common method.

" in crown-grafting.

" with strips of bark.

Crown-grafting by inlaying.

Side-grafting by inlaying.

4.-Cleft-grafting, common single.

" " " double.

" " " oblique.

" " $"$ terminal.

" " " " woody.

" " " " herbaceous.

5.-Whip-grafting, simple.

Saddle-grafting. complex.

6.-Mixed grafting.

Grafting with cuttings :

When the scion is a cutting.

When the stock is a cutting.

When both are cuttings.

Root-grafting of a plant on its own root. 
Ways of Grafting and Budding, continued.

Root-grafting of a plant on the roots of another plant.

Grafting with fruit-buds.

\section{Bud-Graftixg. (Budding.)}

1.-Grafting with shield-buds.

Bud-grafting under the bark, or by inoculation.

" "6 ordinary method.

" " w with a cross-shaped incision.

" " " " the incision reversed.

" " by veneering.

Bud-grafting, the combined or double method.

2.-Flute-grafting.

" " " Common method.

" "6 With strips of bark.

\section{Particular Methods by which Various Fruits are Multiplied.}

Barberry . . . . Cuttings of mature wood; seeds.

Orange . . . . . Seeds; seedlings budded or grafted.

Figs . . . . Cuttings, either of soft or mature wood.

Mulberry . . . Cuttings of mature wood. Some varieties are root-grafted, and some are budded.

Olive. . . . Cuttings of mature or even old wood. Chips from the trunks of old trees are sometimes used.

Pomegranate - Cuttings, layers and seeds.

Apple and Pear. Seeds; seedlings budded or grafted.

Peach and other stone-fruits-

Seeds; seedlings budded.

Quince . . . . Cuttings, usually; the cuttings often grafted.

Grape . . ... Cuttings of from one to three buds; layers.

Currant and Gooseberry-

Cuttings.

Raspberries, red.Suckers from the root; root-cuttings.

"، bl'k.Layers from tips of canes; root-cuttings.

Blackberry . . . Root-cuttings; suckers from the root.

Cranberry . . . Layers or divisions.

Strawberry . . . Runners; tip-cuttings. 
8. Stocks Used for Various Fruits.

Almond . . . . . Peach, hard-shelled almond, plum.

Apple...... Common apple seedlings, Paradise and Doucin stocks, crab-apple and wild crab.

Apricot . . . . . Apricot and peach in mild climates and plum in severe ones.

Cherry ....... Mazzard stocks are preferred for standards; Mahaleb stocks are used for dwarfing.

Medlar . . ... . Hawthorn, medlar, quince.

Mulberry . . . . . . Seedlings of white mulberry.

Orange ...... Otaheite orange, shaddock; Citrus trifoliata, particularly for dwarfs.

Peach and Nectarine. . Peach. Plum is often used when dwarfs are wanted, or when the peach must be grown in a too severe climate or upon heavy soil.

Pear . . . . . Pear; quince, mountain-ash, or thorn for dwarfs. Apple temporarily.

Persimmon, Japanese . Native persimmon.

Plum ..... . Plum, Myrobolan plum, peach.

Quince . . . . . The finer varieties are sometimes grafted upon strong-growing kinds like the Anger's

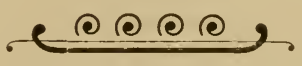

Theory is the general,-practice, the soldiers. - LEONARDO DA VINCI. 


\section{CHAPTER XII.}

Methods of Keeping and Storing Fruits and Vegetables.

\section{Apples.-}

1. Keep the fruit as cool as possible without freezing. Select only normal fruit, and place it upon trays in a moist but well ventilated cellar. If it is desired to keep the fruit particularly nice, allow no fruits to touch each other upon the trays, and the individual fruits may be wrapped in tissue paper. For market purposes, pack tightly in barrels, and store the barrels in a very cool place.

2. Some solid apples, like Spitzenberg, are not injured by hard freezing, if they are allowed to remain frozen until wanted and are then thawed out very gradually.

3. Many apples, particularly russets and other firm varieties, keep well when buried after the manner of pitting potatoes. Sometimes, however, they taste of the earth. This may be prerented by setting a ridge-pole over the pile of apples in forked sticks. and making a roof of boards in such a manner that there will be an air-space over the fruit. Then cover the boards with straw and earth. Apples seldom keep well after removal from a pit in spring.

4. Apples may be kept by burying in chaff. Spread chaff -buckwheat-chaff is good-on the barn-floor, pile on the apples and cover them with chaff and fine broken or chopped straw two feet thick, exercising care to fill the interstices.

Pears.-Pears should be picked several days or a couple of weeks before they are ripe, and then placed in a dry and well-rentilated room, like a chamber. Make very shallow piles, or better, place on trays. 


\section{Keeping and Storing Fruits and Vegetables. 105}

Figs.-After the figs are gathered and dried in the same way as peaches or apricots, wash to remove all grit, and spread in shallow pans and set them in the oren to become thoroughly heated, taking care to prevent scorching. Then roll in powdered sugar, which has been rolled to remove all lumps. When cold, pack away, preferably in paper bags. They tiake a delicious lunch with a bowl of milk. They also help to make a nice dessert.

Gooseberries keep well if kept tight in common bottles filled with pure water. Be sure that none but perfect berries are admitted, and keep in a cool place.

\section{Grapes.-}

1. The firm grapes usually keep best-as Catawba, Vergennes, Niagara, Diana, Jefferson, etc. Thickness of skin does not appear to be correlated with good keeping qualities. Always cut the bunches which are to be stored on a dry day, when the berries are ripe, and carefully remove all soft, bruised and imperfect fruits and all leaves. Keep the fruit dry, cool, and away from currents of air. Many varieties keep well if simply placed in shallow boxes or baskets and kept undisturbed in a cool place.

2. Pack the bunches in layers of dry, clean sand.

3. Pack in layers of some small grain, as wheat, or oats, or barley.

4. Cork-dust is also excellent for use is packing grapes. This cork can be had from grocers who handle the white Malagas, which are packed in this material.

5. Pack the bunches in finely cut, soft and dry hay, placing the grapes and hay in consecutive layers.

6. Dry hardwood sawdust is also good for packing.

7. Place on shelves in a cool, airy room. After a few days wrap the bunches separately in soft paper and pack in shallow pasteboard boxes, not more than two or three layers deep. Tíeep in a cool, dry room that is free from frost.

8. Cut the bunches with sharp scissors, place in shallow baskets, but few in a basket, and after reaching the house dip the cut end of stems in melted wax. Now take tissue paper or very thin manila paper cut just to the right size, 
Grapes, continued.

and carefully wrap each cluster of grapes. Secure shallow tin boxes; place a layer of cotton-batting at the bottom, then a layer of grapes, then batting; three layers of grapes are enough for one box, alternating with cotton-batting, and topping with batting; then gently secure the lid to each box, and when done place in cold-storage for use in April or even later. If cold-storage cannot be had, put in a dry, cool room, and when cold weather approaches cover in an interior closet with just sufficient covering to prevent freezing; warmth will cause over-ripening and deterioration. '

9. Roe's MEтhod.-In a stone jar place alternate layers of grapes and straw paper, the paper being in double thickness. Over the jar place a cloth and bury bolow frost in a dry soil. The grapes will keop until New-Year's.

Keeping Grapes for Market (W. M. Pattison, Quebec).It is the generally received opinion that the thick-skinned native seedlings are the only keepers. This is correct as regards preserving flaror, but sereral hybrids of foreign blood are the best keepers known. Before giving results of this and former trials, instructions in packing may bo of service. The rarieties intended to be laid up for winter use should be those alone which adhere well to the stem and are not inclined to shrivel. These should be allowed to remain on the vines as long as they are safe from frost. A clear dry day is necessary for picking, and careful handling and shallow baskets are important. The room selected for the drying-process should be well ventilated, and the fruit laid out in single layers on tables or in baskets where the air circulates freely, the windows being closed at night and in damp weather. In about ten days the stems will be dried out sufficiently to prevent molding when laid away. When danger from this is orer, and the stems resemble those of raisins, the time for packing has arrived. In this, the point to be observed is to exclude air proportionately with their tendency to mold. I have used baskets for permanent packing, but much prefer shallow trays or boxes of uniform size to be packed on each other, so that each box forms a cover for the lower, the uppermost only needing one. Until 


\section{Keeping and Storing Fruits and Vegetables. 107}

Grapes, continued.

very cold weather, the boxes can be piled so as to allow the remaining moisture to escape through a crevice about the width of a knife-blade. Before packing, each bunch should be examined, and all injured, cracked and rotten berries remored with suitable seissors. If two layer's are packed in a box, a sheet of paper should intervene. The boxes must be lrept in a cool, dry room or passage, at an even temperature. If the thermometer goes much below freezing-point, a blanket or newspaper can ba thrown over them, to be removed in mild weather. Looking over them once in the winter and removing defective berries will suffice, the poorest keepers being placed accessible. Under this treatment the best keepers will be in good edible order as late as February, after which they deteriorate.

The following is a list of grapes worth noticing, that have been tested for keeping:

\begin{tabular}{|c|c|c|}
\hline \multicolumn{2}{|c|}{ I)ESCRIPTION. } & List of GRAPES TO BE RECOMMENDED. \\
\hline & Nov. 1st & Lady, Antoinette, Carlotta, Belinda. \\
\hline$\frac{5}{3}$ & Dec. Ist. & $\begin{array}{l}\text { Lady Washington, Peter Wiley, Mason, Worden, } \\
\text { Senasqua, Romell's Superior, Ricketts' No. 546, } \\
\text { Concord, Delaware. }\end{array}$ \\
\hline 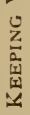 & Jan. Ist. & $\begin{array}{l}\text { Duchess, Essex, Barry, Rockland, Favorite, Aminia, } \\
\text { Garber, Massasoit, Dempsey's No. 5, Burnet, } \\
\text { Undine, Allen's Hybrid, Agawam, Gen. Pope, } \\
\text { Francis Scott. }\end{array}$ \\
\hline 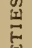 & Jan. 15th. & Salem, Vergennes, El Dorado. \\
\hline$>$ & Feb. 1st. & $\begin{array}{l}\text { Wilder, Herbert, Peabody, Rogers' No. 30, Gærtner, } \\
\text { Mary and Owosso. }\end{array}$ \\
\hline
\end{tabular}

Orange.-Aside from the customary wrapping of oranges in tissue paper and packing them in boxes, burying in dry sand is sometimes practiced. The fruit is first wrapped in tissue paper, and it should be buried in such manner that the fruit shall not be more than three tiers deep. 
Crystallized or Glace Fruit.-The principle is to extract the juice from the fruit and replace it with sugar syrup, which hardens and preserves the fruit in its natural shape. The fruit should be all of one size and of a uniform degree of ripeness, such as is best for canning. Peaches, pears and similar fruits are pared and cut in halves; plums, cherries, etc., are pitted. After being properly prepared, the fruit is put in a basket or bucket with a perforated bottom and immersed in boiling water to dilute and extract the juice. This is the most important part of the process, and requires great skill. If the fruit be left too long, it is over-cooked and becomes soft; if not long enough, the juice is not sufficiently extracted, and this prevents perfect absorption of the sugar. After the fruit cools, it may again be assorted as to softness. The syrup is made of white sugar and water. The softer the fruit, the heavier the syrup required. The fruit is placed in earthen pans, covered with syrup and left about a week. This is a critical stage, as fermentation will soon take place, and when this has reached a certain stage the fruit and syrup are heated to the boiling point, which checks the fermentation. This is repeated, as often as may be necessary, for about six weeks. The fruit is taken out of the syrup, washed in clean water, and either glaced or crystallized, as desired. It is dipped in thick syrup, and hardened quickly in the open air for glacing, or left to be hardened slowly if to be crystallized. The fruit is now ready for packing, and will keep in any climate.

Preserving Fruits for Exhibition.-Several methods are employed. Perhaps the best is to place the fruits in corrosive sublimate -which is a violent poison-prepared at the rate of half an ounce to a gallon of water. Renew the liquid every year or two. Distilled or other very pure water should be used if it is desired to retain the color of the fruit.

Sulphur is sometimes used as follows : Put 30 gallons of water in a 40-gallon barrel; float on top of the water a tin pan, in which put a little sulphur. Set the sulphur on fire and cover tightly until the fire goes out; renew the sulphur several times, opening the barrel for renewal of air between the doses. This fluid is then used as a preservative. 


\section{Keeping and Storing Fruits and Vegetables}

Preserving Fruits for Exhibition, continued.

A satisfactory fluid is made by placing an ounce of salicylic acid in 5 gals. water, and then adding a little glycerine. The amount of glycerine will depend upon the juiciness of the fruit. The greater the juiciness, the more glycerine must be added. From $S$ to $\mathbf{1 5}$ per cent. may be considered an average.

Cabbage.-The most satisfactory method of keeping cabbages is to bury them in the field. Select a dry place, pull the cabbages and stand them head down on the soil. Cover them with soil to the depth of six or ten inches, covering very lightly at first to prevent heating-unless the weather should quickly become severe-and as winter sets in cover with a good dressing of straw or coarse manure. The cabbages should be allowed to stand where they grew until cold weather approaches. The storing-beds are usually made about 6 or 8 feet wide, so that the middle of the bed can be reached from either side, and to prevent heating if the weather should remain open. Cabbages quickly decay in the warm weather of spring.

Cabbage for family use is most conveniently kept in a barrel or box half buried in the garden. Cabbages and turnips should never be kept in the cellar, as when decaying they become very offensive.

Celery.-For market purposes, celery is stored in temporary board pits, in sheds, in cellars, and in various kinds of earth pits and trenches. The points to be considered are, to provide the plants with moisture to prevent wilting, to prevent hard freezing, and to give some ventilation. The plants are set loosely in the soil. There are several methods of keeping celery in an ordinary cellar for home use. The following methods are good:

Take a shoe or similar box. Bore one-inch holes in the sides, four inches from bottom. Put a layer of sand or soil in the box, and stand the plants, trimmed carefully, upon it, closely together, working more sand or soil about the root part, and continue until the box is full. The soil should be watered as often as needed, but always through the holes in the side of the box. Keep the foliage dry. 
Celery, continued.

Celery may also be stored and well blanched at the same time, in a similar way, by standing it in a barrel upon a layer of soil. Some roots and soil may be left adhering to the plants. Crowd closely, water through holes near the bottom as in case of box storage, and keep the plants in the dark.

Blanched celery can also be preserved for a long time by trimming closely and packing upright in moss inside of a box. A large quantity of the vegetable may thus be stored in a small space.

Onions demand a dry cellar, and the bulbs should be thoroughly dried in the sun before they are stored. All tops should be cut away when the onions are harvested. If a cellar cannot be had, the bulbs may be allowed to freeze, but great care must be exercised or the whole crop will be lost. The onious must not be subjected to extremes of temperature, and they should not thaw out during the winter. They can be stored on the north side of a loft, being covered with two or three feet of straw, hay or chaff to preserre an equable temperature. They must not be handled while frozen, and they must thaw out very gradually in the spring. This method of keeping onions is reliable only when the weather is cold and tolerably uniform.

Roots of all sorts, as beets, carrots, salsify, parsnips, can be kept from wilting by packing them in damp sphagnum moss, like that used by nurserymen. They may also be packed in sand. It is an erroneous notion that parsnips and salsify are not good until after they are frozen.

Squashes should be stored in a dry room in which the temperature is uniform and about $50^{\circ}$. Growers for market usually build squash-houses or rooms and heat them. Great care should be taken not to bruise any squashes which are to be stored. Squashes procured from the market have usually been too roughly handled to be reliable for storing.

Sweet-potatoes.-Ix тнE NorTH.-Dig the potatoes on a sunny day, and allow them to dry thoroughly in the field. Sort out the poor ones and handle the remainder carefully. Never allow them to become chilled. Then pack them in barrels in 


\section{Keeping and Storing Fruits and Vegetables. I I I}

Sweet-potatoes, cuntinued.

layers, in dry sand, and store in a warm cellar. They are sometimes stored in finely broken charcoal, in charcoal-dust, wheat-chaff and similar substances.

Sometimes they are kept in small and open crates, without packing-material, the crates being stacked so as to allow thorough ventilation. The Hayman or Southern Queen keeps well in this way.

A warm attic is often a good place in which to store sweetpotatoes. A tight room over a kitchen is particularly good when it is so arranged that the heat from the kitchen can be utilized in warming it.

Is THE South (Berckmans).-Digging the tubers should be delayed until the vines have been sufficiently touched by frost to check vegetation. Allow the potatoes to dry off in the field, which will take but a few hours. Then sort all those of eating-size to be banked separately from the smaller ones. The bauks are prepared as follows: Make a circular bed six feet in diameter, in a sheltered corner of the garden, throwing up the earth about a foot high. Cover this with straw and bank up the tubers in shape of a cone, using from 10 to 20 bushels to each bank. A triangular pipe made of narrow planks to act as a ventilator should be placed in the middle of the cone. Cover the tubers with straw 6 to 10 inches thick and bank the latter with earth, first using only a small cuantity, but increasing the thickness a week or ten days afterwards. A board should be placed upon the top of the ventilating-pipe to prevent water from reaching the tubers. Several banks are usually made in a row, and a rough shelter of boards built over the whole. The main point to be considered in putting up sweet-potatoes for winter is entire freedom from moisture and sufficient covering to prevent heating. It is therefore advisable to allow the tubers to undergo sweating (which invariably oceurs after being put in heaps) before covering them too much; and if the temporary covering is removed for a few hours, a week after being heaped, the moisture generated will be removed and very little difficulty will follow from that cause. If covered too thickly at once, the sweating often engenders 
Sweet-Potatoes, continued.

rapid fermentation, and loss is then certain to follow. Sand is never used here in banking potatoes. Some varieties of potatoes keep much better than others. The Yellow Sugar Yam and the Pumpkin Yam are the most difficult to carry through; while the Trinidad potato keeps as readily as Irish potatoes, only requiring to be kept free from frost and light by a slight covering of straw, if the tubers are placed in a house. Next in keeping quality come the Hati Yam, the Red-skinned, Brimstone, Nigger Killer; and the last of the potato section is the Nansemond.

Tomatoes.-Pick the firmest fruits just as they are beginning to turn, leaving the stems on, exercising care not to bruise them, and pack in a barrel or box in clean and thoroughly dry sand, placing the fruits so that they will not touch each other. Place the barrel in a dry place.

In the autumn, when frosts appear, tomatoes, if carefully picked and laid on straw under the glass of cold-frames, will continue to ripen until near Christmas. Fruit ripened in this way seems to be as good as that ripening naturally on the vines.

The ripening of tomatoes may be hastened ten days by bagging them as grapes are bagged.

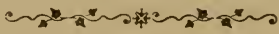

These are arts pursued without a crime,

That leave no stain upon the wings of Time.

-COWPER. 


\section{CHAPTER XIII.}

\section{Standard and Legal Measures and Sizes.}

\section{Standard Flower-Pots.}

American.

The Society of American Florists has adopted a standard pot, in which all measurements are made inside, and which bears a lim or shoulder at the top. The breadth and depth of these pots are the same, so that they "nest" well.

Exglish-Chiswick Standards.

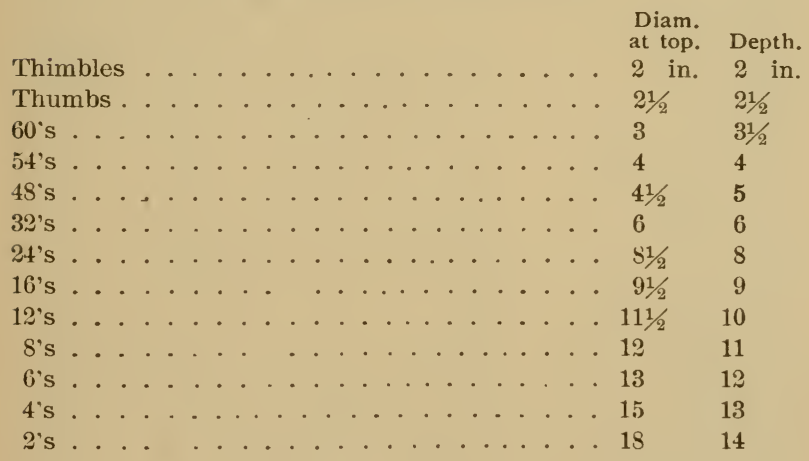


2. Legal and Stan

Legal Weights of a Bushel of Produce

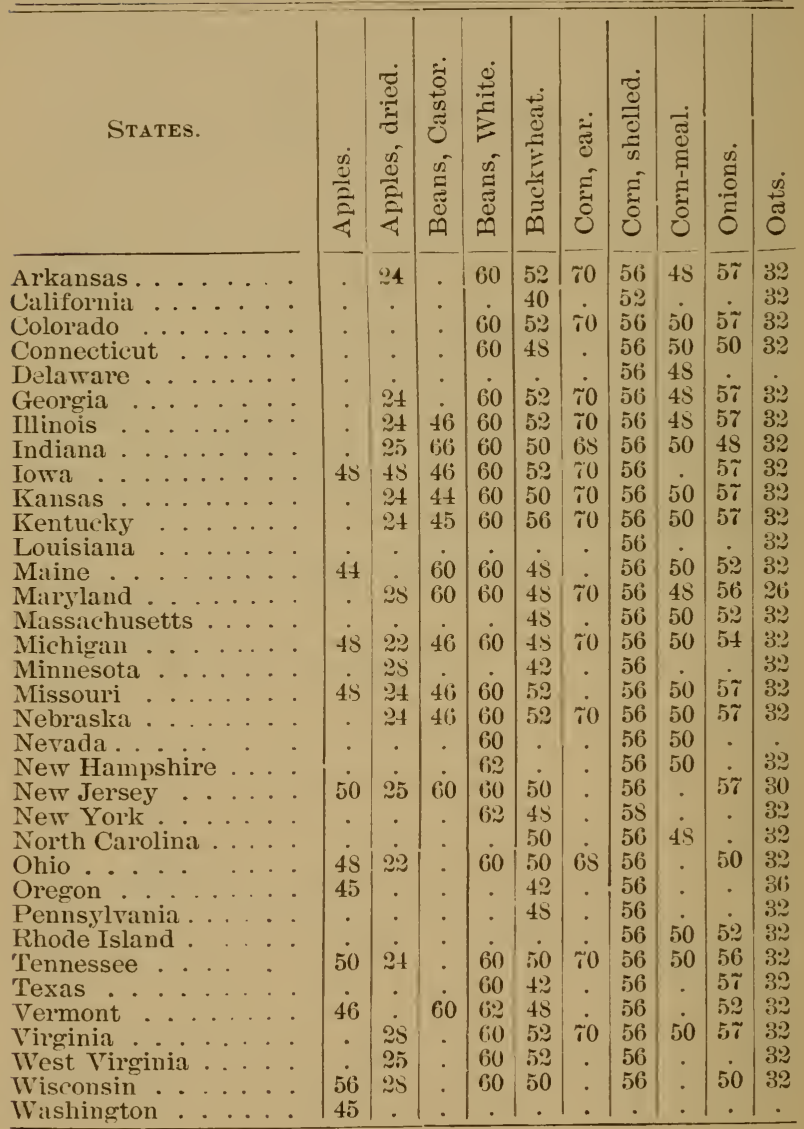


dard Measures.

in various States, corrected to $I \delta 9 I$.

\begin{tabular}{|c|c|c|c|c|c|c|c|c|c|c|c|c|c|c|}
\hline 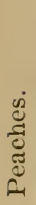 & 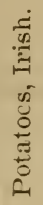 & 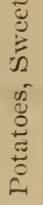 & $\underbrace{\dot{n}}_{\tilde{C}}$ & $\frac{0}{3}$ & 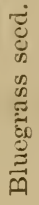 & 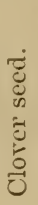 & 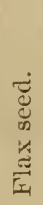 & $\underset{\vec{D}}{\overrightarrow{0}}$ & 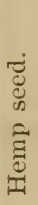 & 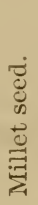 & 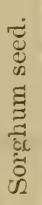 & 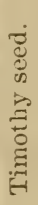 & $\underset{\text { Eี }}{\stackrel{\infty}{\Xi}}$ & B \\
\hline * & 60 & 50 & 60 & 56 & 14 & 60 & $56 j$ & $4 S$ & . & 50 & 50 & 60 & 57 & 60 \\
\hline - & & - & . & 54 & & & . & 50 & & . & . & & . & 60 \\
\hline . & 60 & . & & 56 & 14 & 60 & & $4 \mathrm{~s}$ & 44 & . & . & 45 & & 60 \\
\hline . & 60 & • & 60 & 56 & . & - & . & 45 & . & . & . & . & 50 & 60 \\
\hline 3s & 60 & 55 & 60 & 56 & 14 & 60 & $56^{\circ}$ & 47 & & . & . & 45 & 55 & 60 \\
\hline 33 & 60 & 5̃. & . & 56 & 14 & 60 & 55 & $4 \mathrm{~s}$ & 44 & . & . & $4 \tilde{5}$ & $5 \tilde{~}$ & 48 \\
\hline $3: 3$ & 60 & 5.5 & . & 56 & & 60 & & 48 & 44 & & & 45 & . & 48 \\
\hline 33 & 60 & 46 & . & 56 & 14 & 60 & 56 & 48 & 44 & 45 & 30 & 45 & & \\
\hline 33 & 60 & 50 & & 56 & 14 & 60 & 56 & 45 & 44 & 50 & . & 45 & $55 ̃$ & 60 \\
\hline 39 & 60 & 55 & 60 & $5 t ;$ & 14 & 60 & 56 & 47 & 44 & 50 & . & 45 & 60 & 60 \\
\hline 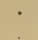 & 60 & . & 60 & 32 & . & . & . & $\begin{array}{l}32 \\
+5\end{array}$ & . & . & . & . & 50 & $\begin{array}{l}60 \\
60\end{array}$ \\
\hline 40 & 60 & 56 & 62 & 56 & 14 & 64 & 56 & 45 & 44 & 50 & . & 45 & 56 & 60 \\
\hline & 60 & & & 56 & & & & 45 & & & . & 45 & & 60 \\
\hline 25 & 60 & 56 & 60 & 56 & 14 & 60 & 56 & $4 \mathrm{~S}$ & 44 & 50 & . & 45 & 58 & 60 \\
\hline 25 & 60 & & & 56 & & 60 & & 45 & & - & . & & & 60 \\
\hline 33 & 60 & $56 j$ & 60 & 56 & 14 & 60 & $56^{\circ}$ & 48 & 44 & . & & 45 & 42 & 60 \\
\hline$\ddot{3}$ & 60 & 50 & 60 & 56 & 14 & 60 & 56 & $4 \mathrm{~S}$ & 44 & 40 & 30 & 45 & 55 & 60 \\
\hline & 60 & . & 60 & 56 & . & 60 & & & . & - & & . & & 60 \\
\hline . & 60 & 54 & 60 & 56 & - & 64 & 55 & 48 & . & . & . & & 50 & . \\
\hline & 60 & . & 60 & 56 & . & 60 & 55 & 48 & . & . & . & 44 & . & \\
\hline & 60 & & 60 & 56 & . & 60 & 55 & 43 & & & . & & & 60 \\
\hline 48 & 60 & 50 & 60 & 56 & . & 60 & 56 & 45 & 44 & 50 & . & 45 & 60 & 60 \\
\hline & 60 & . & . & 50 & . & 60 & . & 46 & . & . & . & . & . & 60 \\
\hline & 56 & . & . & 56 & . & 62 & . & $4 \pi$ & . & . & . & . & . & . \\
\hline & 60 & & & 56 & & & & 48 & . & & . & & & \\
\hline 50 & 60 & 50 & 60 & & 14 & 60 & 56 & 48 & . & 50 & . & 45 & 50 & 60 \\
\hline . & 60 & 55 & & 56 & . & 60 & 56 & 45 & . & . & . & 45 & 55 & 60 \\
\hline & 60 & & 60 & 56 & & 60 & & 45 & & & . & 45 & & 60 \\
\hline 40 & 60 & 56 & 60 & 56 & 14 & 60 & 56 & 48 & 44 & 50 & . & 45 & $5 \tilde{5}$ & 60 \\
\hline 33 & 60 & . & . & 56 & . & 60 & 56 & 45 & . & . & . & 45 & & 60 \\
\hline 28 & 60 & . & . & 56 & . & 60 & 56 & 48 & . & . & & 45 & 42 & - \\
\hline$\therefore$ & . & . & . & $\cdot$ & . & $\cdot$ & $\cdot$ & . & $\cdot$ & . & $-i$ & . & $\cdot$ & \\
\hline
\end{tabular}




\section{Miscellaneous Legal Weights Per Bushel.}

BeEts: 60 lbs. in Maine, Vermont, Connecticut. Carrots: 50 lbs. in Maine and Vermont, 55 in Connecticut. Parsvips: 45 lbs. in Connecticut. Sweet-Potatoes: 54 lbs. in New Jersey, 46 in Dakota, 50 in Ohio, Kansas, Nebraska, 5̃ in Indiana, Kentucky, Texas, Georgia, 56 in Michigan, Virginia, Missouri, 46 in Iowa. Berries: $32 \mathrm{lbs}$. in Rhode Island. Cherries, Grapes, Currants, Gooseberries, weigh 40 lbs. in Iowa. Blackberries, Strawberries, Raspberries, 32 lbs. in Iowa. Peaches, Quinces, 48 lbs. in Iowa. Drred Plums, 28 lbs. in Michigan. Cranberries, 40 lbs. in Michigan. "Wiln Peaches," 33 lbs. in Ohio.

\section{Miscellaneous Legal Sizes.}

The heap bushel contains 2,564 cubic ins. in Connecticut and Kansas; 2,150.42 ins. in New Jersey, Pennsylvania, Nebraska, Tennessee, Missouri, Washington.

The bushel measure must be $191 / 2$ ins. in outside diameter, the half-bushel $15 \frac{1}{2}$ ins., the peck $12 \frac{1}{2}$ ins. in New York and California.

The bushel measure must be $181 / 2$ ins. in inside diameter, the half-bushel $13 \frac{3}{4}$ ins., the peck $103 / 4$ ins. and the half-peck 9 ins. in New Hampshire and Minnesota.

Produce sold by dry measure must be heaped as full as the measure will hold in Ohio, Illinois, Michigan, Wisconsin, Minnesota, California, Oregon and Washington.

Heap measures must be cylindrical, with a plane bottom, in New York and California.

The half-bushel is $13_{ \pm 0}^{39}$ ins. in interior diameter and $7 \frac{1}{24}$ ins. deep in Ohio. It contains $1,075 \frac{1}{5}$ cubic Ins. in Indiana.

In New Jersey the cranberry-box, to hold a bushel, must be $12 \times 83 / 4 \times 22$ ins. in the clear.

In Wisconsin, cranberry packages must conform to the following sizes: "The legal and standard cranberry-barrel in this state shall be twenty-three and three-quarter inches high, sixteen and one-fourth inches in diameter at the head, and eighteen inches in diameter at the bilge, inside measure. Every manufacturer of barrels for cranberries shall stamp or brand his name with the letters IV. S. on such barrels, to indicate that they are the Wisconsin Standard in size. All sales of cranberries in 
Miscellaneous Legal Sizes, continued.

packages less than a barrel should be by the bushel or quart, struck or level dry measure. A standard bushel crate for cranberries shall be twenty-two inches long, twelve and one-fourth inches wide by seven and one-half inches deep, inside measure."

In Michigan the quantity known as a box or a basket of peaches shall contain $\pi 16 \frac{4}{5}$ cubic ins. or $1 / 3$ of a bushel, strict measure.

In New York a barrel of apples, quinces, pears or potatoes shall contain 100 quarts of grain or dry measure, except that potatoes, when sold by weight, shall be 1 ia lbs. to the barrel.

In New York the measure for fruit shall be the half-bushel, which shall be made cylindrical, the diameter outside to outside $15 \frac{1}{2}$ ins. The standard half-bushel has $1,075 \frac{21}{100}$ cubic ins.

Michigan Standard Measure.-The half-bushel or parts thereof shall be the standard measure for fruits customarily sold by heaped measure; and, in measuring said commodities, the half-bushel or other small measure shall be heaped as high as may be, without special effort or design.

Michigan Standard Barrel. - A barrel of fruit, roots or regetables is the quantity contained in a barrel made from staves 27 ins. in length, and each head $16 \frac{1}{2}$ ins. in diameter, or ordinary flour-barrel size.

The standard weight of apples is $48 \mathrm{lbs}$. to the bushel.

In Tennessee a barrel of apples contains $21 / 2$ bushels. A liquid barrel contains 42 gals.

In Wisconsin a barrel of apples shall contain 100 quarts dry measure.

The avoirdupois pound bears to the troy pound the relation of 7,000 to 5,760 in New York, New Jersey, Pennsylvania, Ohio, Iowa, Nebraska, Tennessee and California.

\section{Society and Customary Standards.}

The standard orange-box adopted by the Florida Fruit Exchange measures $12 \times 12 \times 27$ inches, with partition in the middle. The Exchange issues the following instructions:

We recommend the following classifications for oranges: Fancy, Choice Bright, Bright Russet, Choice Russet, Russet.

Oranges classed as Fancy should be extra-bright, with very smooth, thin skin. Rough, thick-skinned fruit, being ever so bright, should never be classed as Fancy. 


\section{Society and Customary Standards, continued.}

Oranges classed as Choice Bright should be strictly bright and fairly smooth skin and of desirable size.

Oranges classed as Bright should be bright and free from rust.

Oranges classed as Bright Russet should be at least two-thirds bright, with smooth slin and of desirable size.

Oranges classed as Choice Russet should be of quite smooth skin and of desirable size.

Oranges of a common dark rariety should be classed as Russet.

Never pack bright and rusty oranges in the same box. Nerer pack large and small oranges in the same box.

One of the most important features in the packing of oranges is the uniform neatness of the packages. Buyers will pay more for fruit that is neatly and properly packed than they will pay for such as is carelessly put up. A box of oranges neatly packed, strapped and marked, naturally attracts the attention of buyers.

After your fruit has been carefully packed in accordance with above instructions, please mark the boxes as follows:

Place the stencil of the Florida Fruit Exchange on one end of the box in center of head.

In the upper left-hand corner of the box-head stencil the quality of orange the box contains-Fancy, Choice Bright, Bright, Bright Russet, Choice Russet, Russet, Mandarin, Tangerine, or. Navel, as the case may be.

In the upper middle of the box-head stencil the number of or"unges the box contains-" 128 ," "176," " 200 ," etc., as the case may be:

In the upper right-hand corner stencil the letters according to . the following schedule:

All sizes under 128 , mark $\mathrm{A}$.

Sizes 128 to 138 , mark B.

Sizes 146 to 160 , mark C.

Sizes 176 to 200 , mark D.

All sizes over 200, mark E.

The Georgia Horticultural Society adopts the one-third bushel oblong crate for peaches and similar fruits. The dimensious of this crate are about $\$ \times 121 / 2 \times 22$ inches. 
Society and Customary Standards, continued.

California. Sizes in Common Use folr Local Markets. (Wickson.)

APPle ANd Pear.-Top, bottom and sides of $1 / 4$-in. and ends of $5 / 8$-in. stuff. The length is 22 ins.; ends 10 by 12 ins. This is called a 50-lb. box, but it contains less weight.

Cherry. $-15 \frac{1}{2}$ ins. in length; ends $\$ \frac{1}{2}$ by $3 \frac{1}{2}$.

FIG.-The two-layer fig-box is 20 ins. long; ends 2 by $3 \frac{1}{2}$ ins., and holds about $20 \mathrm{lbs}$. The single layer is the same length and width, but 2 ins. deep and holds about $12 \mathrm{lbs}$.

Grapes.-The same as that used for plums in distant shipment, except that the depth is usually 5 ins., and the contents about 25 lbs. of fruit. Grapes are also shipped in 4-lb. splint baskets, of which 4 go in a half crate or $S$ in a whole crate.

Meloxs.-Cantaloupe crates 38 ins. long, 16 ins. wide and 15 ins. deep. Watermelon's come in bulk in cars or in large cases of all descriptions.

Oraxges. - Flat boxes $2: 2$ ins. long, ends $\pi 3 / 4$ by $1 \tau 1 / 2$ ins. It is divided into two parts by a central partition. The prevailing orange-box at present is about $26 \frac{1}{2}$ ins. long, ends $11 \frac{1}{4}$ ins. square, with a central partition.

Suall Fruts.-Chests or crates which contain 10,15 or 20 drawers. The drawers are $15 \frac{1}{2}$ ins. long, ends $81 / 4$ by $13 / 4$ ins. The sizes have been constantly decreasing. The old drawers held $5 \mathrm{lbs}$. of strawberries; the present weight is about $4 \mathrm{lbs}$.

Packages for Dried Fruits. -25-1b. box: Inside measurements-length, $13 \frac{3}{4} / 4$ ins. ; width, $93 / 4$ ins. ; depth, $5 \frac{8}{4}$ ins. Outside measurements-length, $15 \frac{1}{4}$ ins. ; width, $101 / 4$ ins. ; depth, $61 / 2$ ins. ; top, bottom and sides, $3 / 8$ of an in. thick; ends $8 / 4$ of an in. thick.

A More Flat Package: Inside measurements-length, 16 ins.; width, 9 ins.; depth, 5 ins. Outside measurements-length, 171/4 ins. ; width, $93 / \frac{1}{4}$ ins.; depth, $5 \frac{3}{1}$ ins. Top, bottom and sides, $3 / 8$ of an in. thick; ends, $5 / 8$ of an in. thick.

Fifty-Pound Box: Inside measurements-length, 151/4 ins. ; width, 9 ins.; depth, 9 ins. Outside measurements-length, $1 \tilde{r}_{1 / 4}$ ins.; width, 10 ins.; depth, 10 ins. Top, bottom and sides, $1 / 2$ in. thick; ends, 1 in. thick. 
Society and Customary Standards, continued.

SACKS For Dried Fruit.-White cotton sacks, made of what is called heavy export goods, are used for shipment of dried fruits. They are 20 by 36 ins., and hold about $80 \mathrm{lbs}$. of fruit.

Raisixs. - 20-1b. raisin-box, $197 / 8$ ins. long, ends 9 by $4 \frac{8}{4}$ ins. Half box, same length and width, depth, $23 / 3$ ins.; quarter box, same length and width, depth, $11 / 4$ ins. ; eighth box, $15 \frac{1}{2}$ ins. long, ends 6 by $1 \frac{1}{4}$ ins.

California Packages for Eastern Shipment as Adopted by the Fruit Union of that State.

The ends of all boxes should be made of $8 / 4$-in. stuff, and all cleats of $3 / 8$-in. stuff. The sides, tops and bottoms of cherry boxes should be $1 / 4$-in. stuff: the sides made of two strips, each of $1 / 4$-in. stuff and $7 / 8$ of an in. in width. Peach, pear and plum boxes should be made of $\frac{3}{16}$-in. stuff. All the lumber used should be dressed as smooth as possible.

Cherry-boxes, capacity 10 lbs. Outside measurements-18 ins. in length; $10 \% / 8$ ins. in width; 3 ins. in depth. Inside measurements-length, $16 \frac{1}{2}$ ins. ; width, $103 / 8$ ins. ; depth, $2 \frac{1}{2}$ ins.

Plum-boxes, capacity $20 \mathrm{lbs}$. Outside measurements $-193 / 4$ ins. in length, $12 \frac{1}{8}$ ins. in width, $43 / 8$ ins. in depth. Inside measurements-length, $81 / 2$ ins. : width, $11 \frac{3}{4}$ ins.; depth, 4 ins.

There are four sizes of peach and apricot-boxes:

First, capacity 22 lbs. Outside measurements $-193 / 4$ ins. in length, $12 \frac{1}{8}$ ins. in width, $4 \frac{3}{8}$ ins. in depth. Inside measurements-length, $18 \frac{1}{2}$ ins. ; width, $11 \frac{1}{4}$ ins. ; depth, $43 / 8$ ins.

Second, capacity $25 \mathrm{lbs}$. Outside measurements $-198 / 4$ ins. in length, $12 \frac{1}{8}$ ins. in width, $5 \frac{1}{4}$ ins. in depth. Inside measurements-length, $15 \frac{1}{2}$ ins.; width, $11 \frac{3}{4}$ ins.; depth, $4 \frac{7}{8}$ ins.

Third, capacity 27 lbs. Outside measurements $-193 / 4$ ins. in length, $12 \frac{1}{8}$ ins. in width, $5 \frac{1}{4}$ ins. in depth. Inside measurements-length, $181 / 4$ ins. ; width, $11 \frac{1}{4}$ ins. ; depth, 53/8 ins.

Fourth, capacity $30 \mathrm{lbs}$. Outside measurements $-19 \frac{3}{4}$ ins. in length, $12 \frac{1}{8}$ ins. in width, $6 \frac{1}{4}$ ins. in depth. Inside measurements-length, $18 \frac{1}{2}$ ins. ; width, $11 \frac{13}{4}$ ins.; depth, $57 / 8$ ins.

Pear-boxes, capacity $40 \mathrm{lbs}$. Outside measurements $-198 / 4 \mathrm{ins}$. in length, $12 \frac{1}{8}$ ins. in width, $87 / 8$ ins. in depth. Inside measurements-length, $18 \frac{1}{2}$ ins. ; width, $11 \frac{1}{4}$ ins. ; depth, $81 / 2$ ins. 
Society and Customary Standards, continued.

Miscellaneous.-Prunes are graded by running them orer screens of various degrees of coarseness. The meshes should be oblong, 2 ins. or more in length for all the sizes, the widths rarying as stated in the table below. The California French prunes are usually sorted in six sizes, by using the following methods :

\section{Grade.} Width of mesh for Width of mesh fur green prunes. dried prunes

Extras, 40 to 50 to pound. . . . 13/8 inch .... . 11/4 inch.

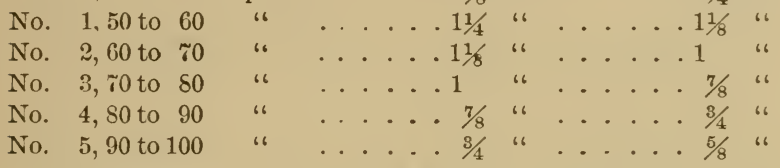

Watermelons are usually sorted into three grades. Of the largest size, about 6 melons are placed in a barrel. Of medium size, about 8 ( 4 melons in cach of two layers), and of the smallest size, 10 to 12. A truck-load of melons comprises about 200 fairsized fruits. A car-load numbers from 1,000 to 1,500.

Cocoanuts are packed for shipment in bags which hold 100.

"Ekimis" branded upon boxes of Smyrna figs means A No. 1, or:Superior Selected. "Eleme" means Selected, the second grade.

\section{Covent Garden (London) Measures.}

Sea-kale Puxwets. -8 ins. diameter at the top, $\pi 1 / 2$ ins. at the bottom, and 2 ins. deep.

R.Inish Pennets. -8 ins. diameter and 1 inch deep, if to hold 6 hands; or 9 ins. by 1 in. for 12 hands.

Meshroom. 7 ins. by 1 in.

Salad Puxnets. -5 ins. by 1 in.

Siere.-Contains 7 imperial gals. Diameter, 15 ins.; depth, 8 ins. A sieve of peas is equal to $1 \mathrm{bu}$. A sieve of currants, 12 qts.

HALF-SiEve.-Contains $31 / 2$ imperial gals. It a verages $12 \frac{1}{2}$ ins. in diameter and 6 ins. in depth.

Bushel Sieve. - 101/2 imperial gals. Diameter at top, 118/4 ins. ; at bottom, 17 ins. ; depth, $11 \frac{11}{4}$ ins.

Beshel Basket ought, when heaped, to contain an imperial bushel. Diameter at bottom 10 ins., at top $141 / 2$ ins.; depth, 17 ins. 


\section{Covent Garden (London) Measures, continued.}

Walnuts, nuts, apples and potatoes are sold by this measure. $\Lambda$ bu. of the last-named, cleansed, weighs 56 lbs., but four pounds additional are allowed if they are not washed.

A JUNK contains $2 / 3$ of a bu.

PоттLE.-A long tapering basket that holds rather over a pint and a half. A pottle of strawberries should hold $1 / 2$ a gal., but nerer holds more than 1 qt. A pottle of mushrooms should weigh $1 \mathrm{lb}$.

HAxp applies to a bunch of radishes, which contains from 12 to 30 or more, according to the season.

Buxde contains from 6 to 12 or 20 heads of broccoli, celery, etc.; sea-kale, 12 to 18 heads; rhubarb, 20 to 30 stems, according to size; asparagus from 100 to 150 .

GraPEs are put up in 2-1b. and 4-1b. punnets; new potatoes by the London growers in 2-1b. punnets. Apples and pears are put up in bu. sieves or half-sieres. A hundredweight of Kentish fi!berts is $104 \mathrm{lbs}$. Weights are always $16 \mathrm{ozs}$. to the $1 \mathrm{~b}$.

Buxch.-Radishes, 12 to 21 ; carrots, 12 and upwards ; turnips, 12 and upwards; leeks, 6 and upwards.

$\Lambda$ RoLL of celery contains 6,8 , to 12 heads or roots.

A score of lettuce or endive is 2 ?.

A TALLY is $\mathbf{5}$ dozen.

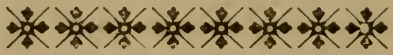

Flowers are the friends of all, and we look with amazement at the person who cannot find some amount of pleasure in their study.

- HILDERIC FRIEND. 


\section{CHAPTER XIV.}

Tables of Measures and Weights.

Dry Measure.

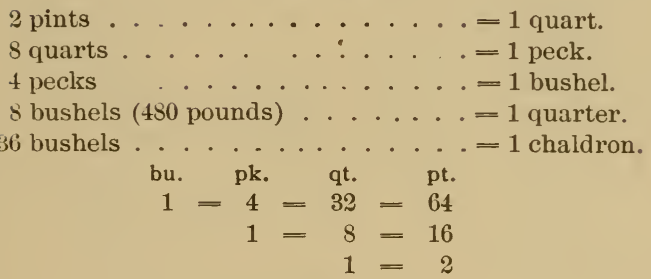

Liquid Measure.

4 gills . . . . . . . . . =1 pint.

2 pints ............... $=1$ quart.

4 quarts . . . . . . . . . = 1 gallon.

$31 \frac{1}{2}$ gallons . . . . . . . . . . . . . 1 barrel.

2 barrels or 63 gallons . . . . . . . = 1 hogshead.

$$
\begin{aligned}
& \text { gal. qt. pt. gi. } \\
& 1=4=8=32 \\
& 1=2=8 \\
& 1=4
\end{aligned}
$$

\section{Apothecaries' Fluid Measure.}

60 minims . . . . . . . . . $=1$ fluidrachm.

8 fluidrams . . . . . . . = 1 fluidounce.

16 fluidounces .......... . = 1 pint.

8 pints . . . . . . . . . . $=1$ gallın. 
Apothecaries' Fluid Measure, continued.

$$
\begin{aligned}
& \text { cong. } o \text { f. } f \text { f. } m \text {. } \\
& 1=8=128=1,024=61,440 \\
& 1=16=128=7,680 \\
& 1=\mathrm{s}=4 \mathrm{S0} \\
& 1=60
\end{aligned}
$$

One minim equals 1 drop of water.

\section{Line or Linear Measure.}

12 inches . . . . . . . . . . $=1$ foot.

3 feet ................ 1 yard.

$5 \frac{1}{2}$ yards, or $161 / 2$ feet ...... . . 1 rod, or pole.

40 rods . . . . . . . . . . $=1$ furlong.

8 furlongs (320 rods) . . . . . . = 1 mile(statute mile)

3 miles . . . . . . . . . . $=1$ league.

$$
\begin{aligned}
& \text { 1. mi. fur. rd. } \mathrm{dd} \text {. } \mathrm{ft} . \mathrm{in} \text {. } \\
& 1=3=24=960=5,250=15,840=190,080 \\
& 1=\mathrm{S}=320=1,760=5,280=63,360 \\
& 1=40=220=660=\tau, 920 \\
& 1=5 \frac{1}{2}=161 / 2=198 \\
& 1=3=36 \\
& 1=12
\end{aligned}
$$

Surveyors' or Chain Measure.

7.92 inches . . . . . . . . . = 1 link.

25 links ............... $=1$ rod or pole.

4 rods, or 66 feet . . . . . . . = 1 chain.

so chains ........... . . = 1 mile.

$$
\begin{aligned}
& \text { mi. ch. rd. } 1 \text {. in. } \\
& 1=80=320=\$, 000=63,360 \\
& 1=4=100=792 \\
& 1=25=198 \\
& 1=7.92
\end{aligned}
$$

Square or Surface Measure.

144 square inches ....... . = 1 square foot.

9 . square feet ........ . . 1 square yard.

$301 / 4$ square yards . . . . . . . $=1$ sq. rod or perch.

160 square rods ........ . . $=1$ acre.

640 acres ............. 1 sq. mile or section. 
Square or Surface Measure, continued.

$$
\begin{aligned}
& \text { sq m. a. sq. rd. sq. yd. sq. ft. } \\
& 1=640-102,400-3,097,600-2 \pi, 8 \pi 8,400=4,014,489,600 \\
& 1=160=4,540=43,560=6,272,640 \\
& 1=\quad 30 \frac{1}{4}=\quad 2721 \frac{1}{4}=\quad 39,204 \\
& 1-9=1,296 \\
& 1=144
\end{aligned}
$$

\section{Surveyors' Square Measure.}

625 square links . . . . . . . = 1 square rod, or pole.

16 poles . . . . . . . . = 1 square chain.

10 square chains ....... . = 1 acre.

640 acres . . . . . . . . . $=1$ square mile or sec.

36 square miles ( 6 miles sq.) . . . $=1$ township.

tp. sq. mi. a. sq. ch. sq. rd. sq. 1.

$1=36-23,040-230,400-3,686,400=2,304,000,000$

\section{Solid or Cubic Measure.}

1728 cubic inches. . . . . . . = 1 cubic foot.

27 cubic feet . . . . . . . . = 1 cubic yard.

16 cubic feet . . . . . . . = cord foot.

8 cord feet, or 128 cubic feet . . . = 1 cord of wood.

$248 / 4$ cubic feet . . . . . . . = 1 perch.

$$
\begin{aligned}
& \text { ru. } y \text { d. cu. ft. cu. in. cd. cd. ft. cu. ft. cu. in } \\
& 1-27=46,656=1=8=12 \mathrm{~s}=221,184 \text {. }
\end{aligned}
$$

\section{Avoirdupois, or Commercial Weight.}

$2 \pi \frac{1}{3} \frac{1}{2}$ grains . . . . . . . . . . . . $1 \mathrm{dram}$.

16 drams . . . . . . . . . $=1$ ounce.

16 ounces .......... . . =1 pound.

25 pounds . . . . . . . . = 1 quarter.

4 quarters, or 100 pounds . . . = 1 hundredweight.

20 hundredweight, or $2,000 \mathrm{lbs} .=1 \mathrm{ton}$.

480 pounds . . . . . . . . = 1 imperial quarter.

100 pounds is also called . . . . . 1 central.

t. cwt. lb. oz.

$1=20-2,000=32,000-512,000$

$1=100=1,600=25,600$

$$
1=16=256=7,000
$$$$
1=16-4,375
$$ 


\section{Troy, or Jewelers' Weight.}

24 grains . . . . . . . . . = 1 pennyweight.

20 pennyweights ......... . . . . ounce.

12 ounces ................. 1 pound.

$$
\begin{aligned}
& \text { lb. oz. pwt. gr. } \\
& 1=12=240=5,760 \\
& 1=20^{\circ}-480 \\
& 1=24
\end{aligned}
$$

\section{Apothecaries' Weight.}

20 grains . . . . . . . . . -1 scruple.

3 scruples . . . . . . . . . . . $=1$ dram.

8 drams ................ 1 ounce.

12 ounces ............... $=1$ pound.

$$
\begin{aligned}
& \text { lb. oz. dr. scr. gr. } \\
& 1=12-96=288=5,760 \\
& 1-8=24=480 \\
& 1=3=60 \\
& 1=20
\end{aligned}
$$

Table of Comparative Weights.

Avoirdupois. Troy. Apothecaries'.

$7,000 \mathrm{gr} .=1 \mathrm{lb} .5,760 \mathrm{gr} .=1 \mathrm{lb} .5,760 \mathrm{gr} .=1 \mathrm{lb}$.

$1 \mathrm{lb} .=1 \frac{31}{14} \mathrm{lbs} .=1 \frac{31}{144} \mathrm{lbs}$.

or $144 \mathrm{lbs} . \quad=175 \mathrm{lbs} . \quad=175 \mathrm{lbs}$.

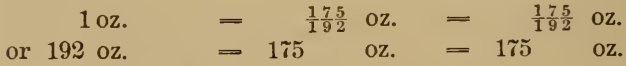

\section{Miscellaneous Tables.}

$\frac{1}{12}$ of an inch . . . . . . . = a line (American).

$\frac{1}{10}$ of an inch . . . . . . $=$ a line (French).

3 inches ........ . = a palm.

4 inches ... . . . . = a hand.

9 inches . . . . . . . = a span.

1s inches ........ . = a cubit.

$21 / 2$ feet ......... . . $=$ a military pace.

3 feet ........ . = a pace.

A wino gallon . . . . . . . . -231 cubic inches.

A dry gallon . . . . . . . . . = 268.8 " 
Miscellaneous Tables, continued.

An imperial gallon . . . . . = 27r.2 44 cubic inches.

A U. S. bushel . . . . . . . . $=2,150.42$

A U. S. bushel heaped . . . . =2,68s

An English bushel . . . . . . = =2,218.192

1 pint of water weighs $1.0431 \mathrm{lbs}$.

1 gallon of water weighs $8.3450 \mathrm{lbs}$.

1 cubic foot of water weighs $62.425 \mathrm{lbs}$. at $39.2^{\circ} \mathrm{F}$.

An English (statute) mile is . . . 1, 760 yards.

A Scotch mile is . . . . . . . 1,984

An Irish mile is . . . . . . . 2,240

A Dutch mile is . . . . . . . . 8,101

A Roman mile is . . . . . . . 1,628

A German mile is . . . . . . 6, 659

A Russian mile is . . . . . . . . 1,100

An Arabian mile is . . . . . . . 2,148

A sea (nautical) mile is . . . . 2,026 "

\section{Equivalents of Metric Measures of Capacity.}

\begin{tabular}{|c|c|c|c|c|}
\hline Metric denominations. & Dry measure. & & Liquid mea & asure. \\
\hline 1 mililiter. . & .001816 pts. & $=$ & .0338 & fl.oz. \\
\hline 1 centiliter & .01816 pts. & $=$ & .338 & fl.oz. \\
\hline 1 deciliter . . & $.181625 \mathrm{pts}$. & $=$ & .84539 & gi. \\
\hline 1 liter ... . & $.90812 \mathrm{~s} q \mathrm{ts}$. & $=$ & 1.056745 & qts. \\
\hline 1 decaliter . . = & $9.0 \mathrm{~s} 128 \mathrm{qts}$. & $=$ & 2.64186 & gals. \\
\hline 1 hectoliter. . = & 2.8379 bus. & $=$ & 26.4156 & gals. \\
\hline 1 kiloliter . . . = & $28.3 \pi 9$ & $=$ & 264.186 & gals. \\
\hline 1 myrialiter.$=$ & 283.79 & $=$ & 2641.86 & gals. \\
\hline
\end{tabular}

\section{Equivalents of Metric Linear Measure.}

Equivalents in English measure.

1 millimeter . . . . . . . . . . . . . . . . . . . .

1 centimeter . . . . . . . . . . . . . .

1 decimeter . . . . . . . . . . 3.93707 "

1 meter . . . . . . . . . . $=39.37079$

1 decameter . . . . . . . . = $=32.80899 \mathrm{ft}$.

1 hectometer . . . . . . $=19.88423$ rods.

1 kilometer . . . . . . . . . . . $=.62138$ mile.

1 myriameter . . . . . . -6.21382 miles. 


\section{Equivalents of Metric Square Measure.}

$1 \mathrm{sq}$. centimeter...... . = . . . . . . .

$1 \mathrm{sq}$. decimeter...... . . . . . 15.5 sq. in.

1 sq. meter ... . . . . . = 1.19603 sq. yds:

$1 \mathrm{sq}$. decameter ....... = 119.6034 sq. yds.

$1 \mathrm{sq}$. hectometer ...... . = 2.47114 sq. rds.

1 sq. kilometer . . . . . . = .3S61 sq. miles.

\section{Equivalents of Metric Cubic Measure.}

$1 \mathrm{cu}$. centimeter . . . . . = .061027 cu. in.

$1 \mathrm{cu}$. decimeter. . . . . . $=61.02 \% 05 \mathrm{cu}$. in.

$1 \mathrm{cu}$. meter, or stere . . . . $=35.3165 \mathrm{~s} \mathrm{cu}$. ft.

Equivalents of Metric Weights.

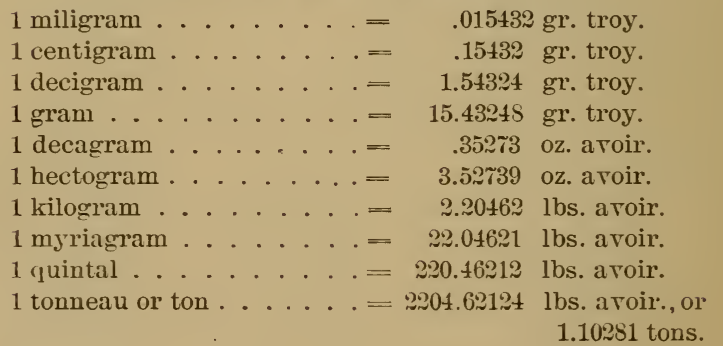

1.10281 tons.

The works of a person that builds, begin immediately to decay; while those of bim who plants begin directly i) improve. 


\section{CHAPTER XV.}

Miscellaneous Tables, Figures and Notes.

1. Quantity of Water Held by Pipes of Various Sizes.

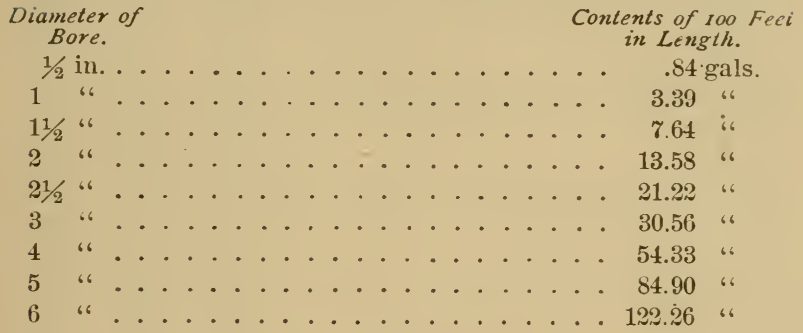

\section{Number of Gallons in Circular Tanks and Wells.}

To find the contents in gallons of circular tanks, etc., square the diameter in feet, multiply by the depth, and then multiply by $58 \% 5$.

GALLONS WHEN THE DEPTH IS

\begin{tabular}{|c|c|c|c|c|c|c|c|c|c|c|}
\hline $4 \mathrm{ft}$ & $\begin{array}{l}3 f t . \\
282.00\end{array}$ & $\begin{array}{c}4 f t . \\
376.00\end{array}$ & $\begin{array}{c}5 f t \\
470.00\end{array}$ & $\begin{array}{c}6 f t . \\
564.00\end{array}$ & $\begin{array}{c}7 f t . \\
65^{8.00}\end{array}$ & $\begin{array}{c}8 f t . \\
752.00\end{array}$ & $\begin{array}{c}9 f t . \\
846.00\end{array}$ & $\begin{array}{l}\text { ro } f t \\
940.00\end{array}$ & $\begin{array}{c}\text { II } f t . \\
1034.00\end{array}$ & $\begin{array}{l}12 f t . \\
1128.00\end{array}$ \\
\hline $5 "$ & 440.63 & $5^{8} 7 \cdot 5^{0}$ & $734 \cdot 3^{8}$ & 881.25 & 1028.13 & II 75.00 & 1321.89 & 1468.76 & $16 I_{5} .63$ & $\mathbf{I}_{762.50}$ \\
\hline $6 "$ & 634.50 & 846.90 & $1057.5^{\circ}$ & 1269.00 & 1480.50 & 1692.00 & I 903.50 & 2115.00 & 2326.50 & $253^{8} .00$ \\
\hline $7 *$ & 863.63 & 1151.50 & 1439.38 & 1727.25 & 2015.13 & 2303.00 & 2590.89 & 2878.76 & 3166.63 & $3454.5^{\circ}$ \\
\hline $8 \cdots$ & 1128.00 & $\mathrm{I}_{5} \mathrm{O}_{4.00}$ & 1880.00 & 2256.00 & 2632.00 & 3008.00 & $33^{84.00}$ & 3760.00 & 4136.00 & 4512.00 \\
\hline 9 & 1427.63 & $1903.5^{\circ}$ & 2379.38 & 2855.26 & 333 I.I3 & 3806.00 & 4282.89 & $475^{8.76}$ & 5234.63 & 5710.52 \\
\hline Io $"$ & $1762.5^{2}$ & 2350.00 & $2937 \cdot 52$ & 3525.00 & 4112.52 & 4700.00 & 5287.56 & $5^{8} 75.04$ & $6461.5^{2}$ & 7050.00 \\
\hline II " & 2132.63 & 2843.50 & $3554.3^{8}$ & 4265.26 & 4976.12 & 5687.00 & 6397.89 & 7108.76 & $7^{819.43}$ & 8530.52 \\
\hline $12 "$. & 2538.00 & 3384.00 & 4230.00 & 5076.00 & 5922.00 & 5768.00 & 7614.00 & 8460.00 & 9306.00 & 10152.00 \\
\hline
\end{tabular}




\section{Number of Gallons in Square-Built Tanks.}

To find the number of gallons in any square or oblong vessel multiply the number of cubic feet contained in it by 7.4805 .

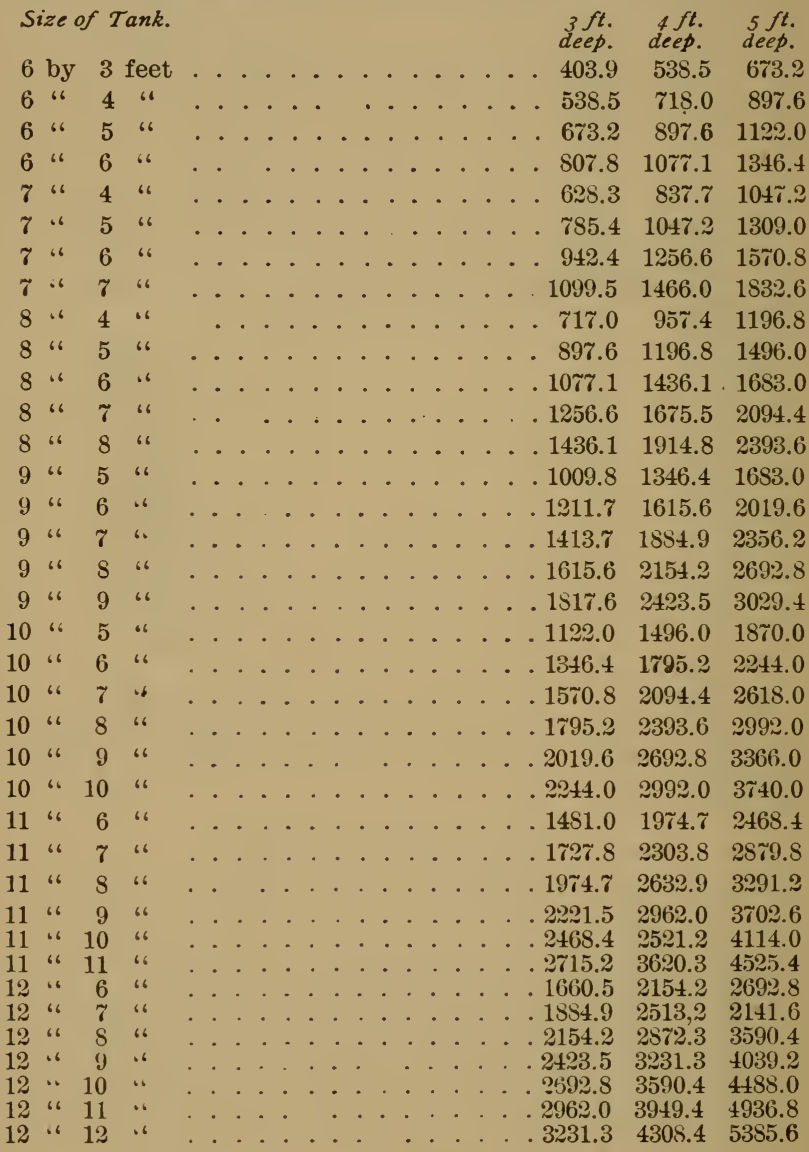




\section{Thermometer Scales.}

Fahrenheit.-The freezing-point is taken as the 32d. degree of the scale, and 180 degrees are made between that and the boiling. point, which therefore becomes $212^{\circ}$.

Centigrade or Celsins. - The freezing-point of water is taken as zero, and boiling-point as $100^{\circ}$.

Reaumur.-The freezing-point of water is taken as zero, the boiling-point as $80^{\circ}$.

A degree Centigrade is therefore greater than a degree of Fahrenheit as nine is greater than five; and a degree of Reaumur is greater, as nine is greater than four.

To reduce Fahrenheit degrees to Centigrade, subtract 32 from the given degree of Fahrenheit and multiply the remainder by 5 and divide it by $9:\left(\mathrm{F} .{ }^{\circ}-32\right) \frac{5}{9}$.

To reduce Centigrade to Fahrenheit, multiply the given degree of Centigrade by 9 and divide the product by 5 , then to the quotient add 32: $\left(\frac{9}{5} \mathrm{C} .^{\circ}+32\right)$.

To reduce Fahrenheit to Reaumur, subtract 32 from the given degree of Fahrenheit and multiply the remainder by 4 and divide by $9:\left(\mathrm{F} \cdot \circ^{\circ}-32\right) \frac{4}{9}$.

To reduce Reaumur to Fahrenheit, multiply the given degree of Reaumur by 9 and divide by 4 , then add $32:\left({ }_{4}^{9} \mathrm{R} \cdot{ }^{\circ}+32\right)$.

\section{Effects of Wind in Cooling Glass.}

\section{(Leuchars.)}

\begin{tabular}{|c|c|c|c|c|c|c|c|c|c|c|c|c|c|c|c|}
\hline $\begin{array}{r}\text { Velocity } \\
\text { per }\end{array}$ & our. & & & & & & & & & & $T i$ & ne & & $\begin{array}{l}\text { uired to } \\
\text { from } 120\end{array}$ & $\begin{array}{l}\text { lower Temperature } \\
\text { to roo Fahr. }\end{array}$ \\
\hline 3.26 & miles & . & . & . & . & . & • & . & & & . . & . & & $2: 5 \mathrm{~S}$ & minutes. \\
\hline 5.18 & 66 & . & . & . & . & • & . & - & & . & . & & - & . $2: 16$ & 6 \\
\hline 6.54 & 6 & . & . & . & . & • & . & . & & . & . & & . & . $1: 91$ & "6 \\
\hline 8.86 & 66 & . & . & . & . & - & . & . & 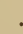 & . & . & & . & $1: 66$ & 6 \\
\hline 10.90 & 66 & . & . & . & . & & - & . & & . & . & & - & $1: 50$ & 6 \\
\hline 13.36 & “" & . & . & . & - & • & & • & & . & . & . & . & . $1: 25$ & "6 \\
\hline 17.97 & .6 & . & . & . & . & & & . & & . & . & . & • & . $1: 08$ & .6 \\
\hline 20.45 & 66 & . & . & . & . & $\cdot$ & * & - & & . & . & . & & $.1: 00$ & “" \\
\hline 24.54 & 66 & . & . & . & . & & & . & & & . . & . & & . : :91 & 66 \\
\hline 27.27 & “ & . & . & . . & • & & & . & & . & & & & . : :81 & 66 \\
\hline
\end{tabular}


6. Per Cent. of Rays of Lignt Reflected from Glass Roofs at Various Angles of Divergence from the Perpendicular.

\section{(Bouyuer.)}

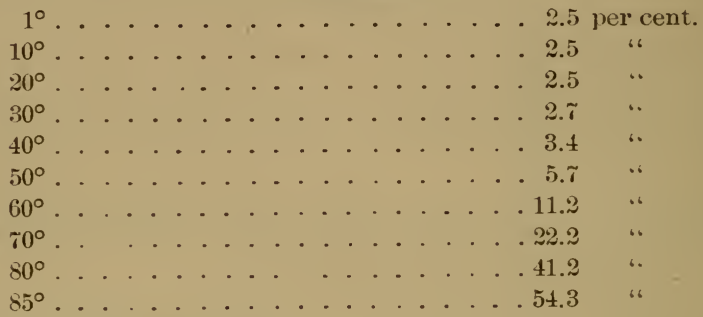

7. Area of Glass in Various States and Provinces, used for Commercial Greenhouse Purposes.

(Stewart.)

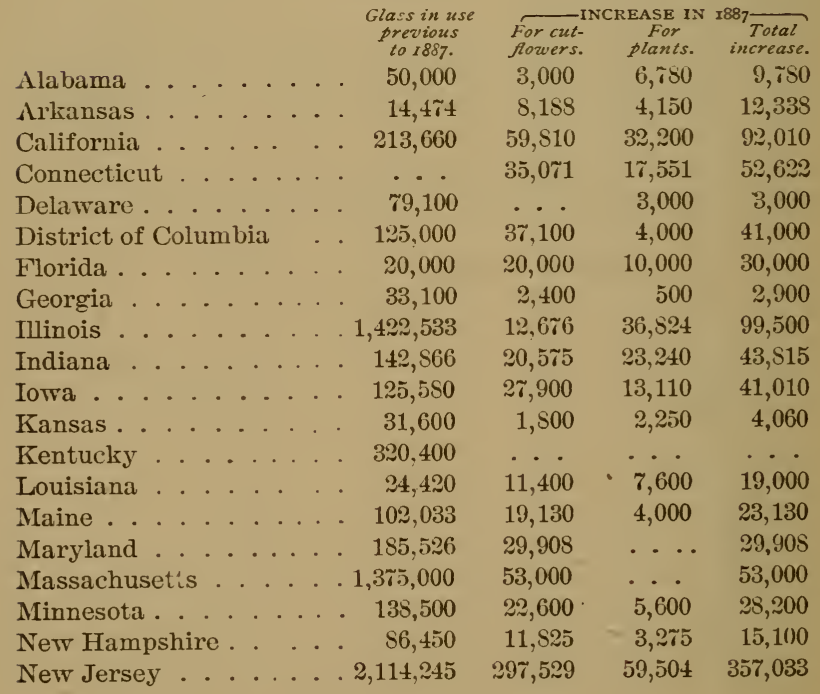


Area of Glass for Commercial Greenhouse Purposes, continued.

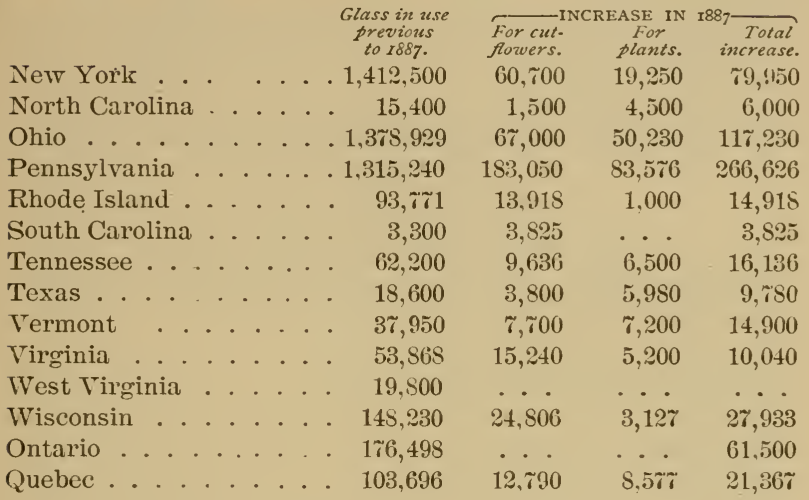

8. National and Party Flowers.

Canada ...... Sugar-Maple.

China . . . . . Narcissus.

Egypt . . . . . . Lotus (Nymphcea Lotus).

England . . . . . Rose.

France . . . . . Fleur-de-lis (Iris).

Germany . . . . . . Corn-flower (Centaurea Cyanus).

Greece (Athens) . . . Violet.

Ireland . . . . . Shamrock (Trifolium, u s u a lly

T. repens).

Italy . . . . . . Lily.

Japan . . . . . . Chrysanthemum.

Prussia . . . . L Linden.

Saxony . . . . Mignonette.

Scotland ..... Thistle.

Spain . . . . Pomegranate.

Wales ...... Leek.

Beaconsfield's followers . . . . . . Primrose.

Bonapartists . . . . . . . . Violet. 
National and Party Flowers, continued.

Ghibellines . . . . . . . . White lily.

Guelphs ............ . Red lily.

Prince of Orange ........ . . The orange.

\section{Dates at which Various Fruits and Nuts Appear in North- ern Markets.}

(From New England Grocer.)

Nuts.-Peanuts, about the first of November.

Walnuts-French, Naples and Grenoble-about the middle of November.

Pecans, about the same time as walnuts.

Filberts, about the first of Norember.

Castanas, early in March.

Almonds, shelled about October first, and Irica and Princess about forty-fire days later.

Shellbarks, October first.

Baracoa cocoanuts begin to come during the latter part of March and the first of April.

Chestnuts, late in September.

Dried Fruits.-Citron (Leghorn), October first.

Currants, the midale of October.

Dates, Fard about the middle of November, and Persian about December 12 .

Prunes, French, about the middle of October, and Turkish a month or so later.

Raisins, Malaga fruit-which includes loose Muscatels, 2, 3, 4 and 6-crown, and Imperial Cabinet layers, B. B., Empire Cluster, Royal and Imperial-begin to put in appearance about the first of November. California raisins begin to come early in October. Sultana raisins are due about October first, and New Valencias about the same time.

Foreigr Green Freit.-Oranges-Messina, Valencia and Palermo, and all Mediterranean fruit, early in December.

Florida oranges generally begin to arrive the first of Norember. Jamaicas get here the middle of September.

Lemons-Messina, Talencia and Palermo, and all Mediterranean fruit, December first. 
Dates Fruits and Nuts Appear in Northern Markets, continued.

Aspinwall, Cuban, Jamaica and Baracoa bananas come the year round, every month in the year, and about every day in the month a portion of the time-certainly every week in each month.

Pineapples, mostly Havanas, come whenever there is a demand for them, the year round. Florida pines come during the latter part of May and the first of June.

Grapes, Malagas, are due about October first.

New figs begin to come along about the same time.

Domestic Green Fruit.-Apples, new, early in August. Russets generally make their appearance upon the market early in the winter, and Gravensteins in December.

Pears, September.

Peaches, Jersey, latter part of August and early in September. Delawares early in August.

Plums, all along from August first to the middle of November. Grapes, Hamburgs, are in the market about all the year round, save, perhaps, three or four months. Catawbas arrive about the middle of August, and Ives about the same time.

Berries. Blueberries, usually in July. Blackberries are liable to arrive any time in June.

Watermelons are with us from the first of June to the first of September.

Cantaloupes. Early in July, lasting about three months.

\section{What Constitutes Wholesale Quantities.}

The wholesale fruit-dealers of Washington, D. C., have adopted the following rules to govern the least quantities of fruits to be sold at wholesale rates:

BaNaNas. - Not less than one bunch.

APPLES.-Not less than one barrel or box as received; no packages to be broken.

Pineapples.-Not less than twenty-five.

Oraxges. - Not less than one box; no packages to be broken.

LExoxs.-Not less than one box; no packages to be broken.

GRAPES OF ALI, KINDS.-Not less than five baskets.

Malaga Grapes.-By the keg only.

Peaches. -Not less than one box or one-bushel crate, or not less than five baskets; no packages to be broken. If in halfbushel lots, not less than two. 
What Constitutes Wholesale Quantities, continued.

PEARs.-One box or barrel; if in baskets, not less than five.

WA TERMELONS. - Not less than twenty-fire.

Muskieloxs.-Not less than twenty-five.

Strawberries axd aLL otmer Berries.-Not less thin a thirty-two quart crate, unless small quantity received. A sixtyquart crate may be halved. An exception made with raspberrics : not less than fifteen quarts. In February and March, strawberries, not less than fifteen quarts.

\section{Average Price in France of Various Orchid Flowers.}

\section{(Orchidophile.)}

From 20 to 25 centimes*: Dendrobium nobile, Tardii.

30 centimes : Cypripcdium insigne, Masdevallia Lindeni Harryana, ignea, Veitchii, Odontoglossum Pescutorei, Rossi.

From 30 to 60 centimes: Odontoglossum crispum (Alexandra), triumphans, luteo-purpureum, Schlieperianum, Insleayi Cattleya amethystina, Skinneri.

From 60 to 75 centimes: Cypripedium villosum, Harrisianum Spicerianum, Boxalli.

From 1 firanc to 1 franc and 25 centimes: Odontoglossum grande, Lycaste Shinneri (price sometimes as low as 50 centimes), Cologyne cristata (per truss), Cattleya labiata, Mossia, Pereivaliana, Gaskeliana, Perrini, Pinelli, elegans, Trianae.

From 1 franc and 50 centimes to 2 francs: Tarious Vandas, Cattleya Domiana.

Trusses of Acrides and Saccolabium sell from a franc and a half to 3 franes, or even for 5 francs for extra-good specimens.

\section{Weights of Various Varieties of Apples per Bushel.}

The following varieties, just from the trees in October, gare the following weights :

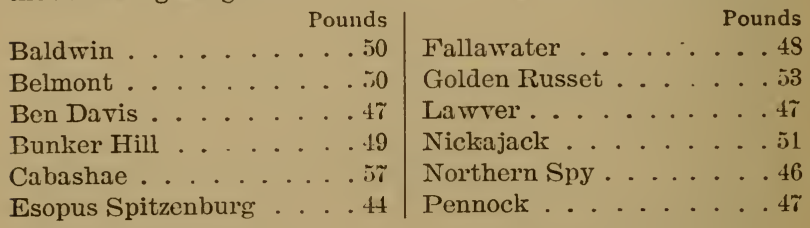

* A centime is about one-fifth of a cent, and a franc is about 20 cents. 
Weights of Various Varieties of Apples, continued.

Pounds

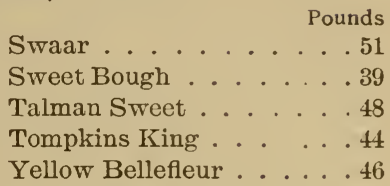

Rambo........ 50

Rhode Island Greening . . . 52

Roxbury Russet . . . . 50

Rubicon ........44

Stark

\section{Various Recipes and Rusle.}

Black ink for zinc labels.-Verdigris, 1 ounce; sal ammoniac, 1 ! ounce; lamp-black, 1/2 ounce; rain water, $1 / 2$ pint. Mix in an earthenware mortar or jar and put up in small bottles. To be shaken before use and used with a clean quill pen on bright zinc.

To keep flower-pots clean.-When the pots are cleaned, soak them a few hours in ammoniacal carbonate of copper (recipe, p. 40.) Soak them about once a year.

To prevent boilers from filling with sediment or scale.-1. Exercise care to get clean water and that which contains little lime. 2. Blow it out often. It can be blown out a little erery day, and occasionally it should be blown off entirely. 3. Put slippery-elm bark in the boiler tank. Or, if slippery-elm is not handy, use potato-peelings, flax-seed, oak-bark, spent tan or coarse sawdust. 4. Put in, with the feed-water or otherwise, a small quantity of good molasses (not a chemical syrup), say $1 / 2 \mathrm{pt}$. to $1 \mathrm{pt}$. in a week, depending upon the size of boiler. This will remove and prevent incrustation without damage to the boiler. These vegetable substances prevent in a measure, by mechanical means, the union of the particles of lime into incrustations.

Cutting glass bottles. - 1 . Pass 5 or 6 strands of coarse packingtwine round the bottle on each side of where you want it divided, so as to form a groove $1 / 8$ inch wide; in this groove pass one turn of a piece of hard-laid white cord, extend the two ends and fasten to some support. Saw the bottle backwards and forwards for a short time; after a minute's friction, by a side motion of the bottle throw it out of the cord into a tub of water, and then tap on the side of the tub and the bottom will fall off.

2. Fill the bottle the exact height you wish it to be cut, with oil of any kind; dip, very gradually, a red-hot iron into the oil. The glass suddenly chips and cracks all round, then the upper surface may be lifted off at the surface of the oil. 
Various Recipes and Rules, continued.

3. For cutting off bottoms of bottles, make a slight nick with a file, and then mark round with a streak of ink where you want it to come off. Make an iron red-hot and lay it on the nick. This will cause it to expand and erack, then by moving the rod round, the crack will follow.

To preserve wooden labels.-Thoroughly soak the pieces of wood in a strong solution of copperas (sulphate of iron); then lay them, after they are dry, in lime-water. This causes the formation of sulphate of lime, a rery insoluble salt, in the wood.

Liquid putty for glazing.-Take equal parts, by measure, of boiled oil, putty and white lead. Mix the putty and oil, then add the white lead. If the mixture becomes too thick, add turpentine. Apply with a putty-bulb.

To prepare paper and cloth for hotbed sash.-1. Use a sash without bars, and stretch wires or strings across it to secure as a rest for the paper. Procure stout but thin manila wrappingpaper, and paste it firmly on the sash with fresh flour paste. Dry in a warm place and then wipe the paper with a damp sponge to cause it to stretch evenly. Dry again and then apply boiled linseed-oil to both sides of the paper, and dry again in a warm place.

2. Saturate cloth or tough thin manila paper with pure raw linseed-oil.

3. Dissolve $13 / 4$ lbs. white soap in $1 \mathrm{qt}$. water; in another quart dissolve $1 \frac{1}{2} \mathrm{oz}$. gum arabic and 5 ozs. glue. Mix the two liquids, warm and soak the paper, hanging it up to dry. Used mostly for paper.

4. 3 pts. pale linseed-oil; 1 oz. sugar of lead; 4 ozs. white rosin. Grind and mix the sugar of lead in a little oil, then add the other materials and heat in an iron kettle. Apply hot with a brush. Used for muslin.

Waterproof paper.-Waterproof paper, transparent and impervious to grease, is obtained by soaking good paper in an aqueous solution of shellac and borax. It resembles parchment paper in some respects. If the aqueous solution be colored with aniline colors, very handsome paper, of use for artificial flowers, is prepared. 


\section{Various Recipes and Rules, continued.}

Cow-dung is highly prized by many gardeners for use in potting soil. It is stored under cover and allowed to remain until dry, being turned several times in the meantime to pulverize it. Manure-water is made either from this dried excrement, or from the fresh material. When made from the fresh material, the manure-water should be made weaker than in the other case.

To find the bushels of shelled corn in a crib or bin of corn in the ear, divide the cubic contents by 2 .

To find the number of bushels of potatoes, apples, etc., in a bin, multiply the cubic contents by 8 and point off one figure in the product.

To find the tons of hay in a mow or stack, divide the cubic contents by about 510 , if the hay is not well settled, or by about 460 if the hay is well packed.

Aproximate value of household measures:

1 teaspoonful equals 1 dram.

1 dessertspoonful equals 2 teaspoonfuls, or 2 drams.

1 tablespoonful equals 2 dessertspoonfuls, or 4 teaspoonfuls.

2 tablespoonfuls equal 8 teaspoonfuls, or 1 ounce.

1 common size wineglassful equals 2 ounces, or $1 / 2$ gill.

A tea-cup is estimated to hold 4 fluidounces, or 1 gill.

1 pound of wheat is equal to about 1 quart.

1 pound and 2 ounces of Indian meal is equal to 1 quart.

1 pound of soft butter is equal to about 1 pint.

1 pound of sugar is equal tc about 1 pint.

\section{Various Figures.}

From 7 to 12 bushels of apples are required for a barrel of cider.

A bushel of average apples gives from 6 to 7 pounds of evaporated product.

Prodect of Dried Raspberries (IV. J. Green):

Ohio ................ 9 lbs, to the bushel.

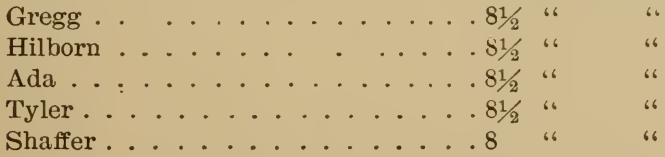


Various Figures, continued.

Raspberries contain from $1 \frac{1}{2}$ to $3 \mathrm{lbs}$. of seeds to the bushel.

A pint of garden blackberries weighs about one pound.

Good clusters of American grapes weigh on an average from one-half to three-fourths pounds, while extra-good clusters will reach a pound and a half. Clusters have been reported which weighed two pounds.

A bushel of sweet-corn ears, "in the milk," with the husks which come from it, weighs from 50 to $70 \mathrm{lbs}$.

There are about 5,000 honey-bees in a pound.

Sanples of Dates on the Title-Pages of Old Books.

$\mathrm{I} \mathrm{D} \ldots . . . . .$. is . 500

MccccIxjij . . . . . is . 1463

MccccLxxz . . . . $14 \pi 2$

MccCCiz . . . . . 1472

MccCc. II . . . . . . . $14 \tau^{2}$

$\operatorname{Mccccxxc} \ldots \ldots 1450$

MCCCCinjXXVIII . . 1488

Miiilic iiii x Vlij . . . . 1458

MCD XCV . . . . . 1495

M. VD . . . . . . 1495

MiijD ...... . . . 1496

MjjjD . . . . . . 1497

MIII.D . . . . . . 1497

MCCCCXCviii . . . . 1498

MID . . . . . . . 1499

MCDXCIX ....... 1499

MccccID . . . . . . 1499

MCCCCXCViiij . . . 1499

MCDXCIX . . . . . 1499

M cccc iCi . . . . . 1500

MD . . . . . . 1500

MCDCII . . . . . 150:
M.DXLIX . . . . . . 1549

$\mathrm{MI} \mathrm{OL}$ or $\mathrm{MDL} \quad \ldots \quad \ldots$

M.D. VIL . . . . . 1554

$\infty$ DLXVI . . . . 1566

$\infty$ DLXX ...... 1570

CIDI $\mathrm{DL}$ xxvI $\ldots 15 \pi 6$

cIoIoLXXX . . . . . 1580

CIOIDXXC . . . . . 1580

CIDI $\mathrm{XXXCI} \ldots . . .15 \mathrm{~S} 1$

$\infty$ DXXCII ..... 1582

MCCCCCLXXXIII . . . 1583

CIC I0 XXCVI . . . . . $15 \mathrm{~S} 6$

$\infty$ D XXCIIX . . . . . . 1588

DICI D XX CIIX . . . . . 15Ss

MDxc . . . . . . 1590

$\mathrm{CI} \mathrm{OI} \mathrm{OCC} \ldots 1 . \ldots 1700$

CIDIDCCL.CIDDCCL . . 1750

CIO.IOCCIXCI $\ldots \ldots$

CIDIDCCC . . . . 1800

MDCCC . . . . . 1800

cIc. IoccC $\ldots \ldots \ldots$ 


\section{CHAPTER XVI.}

\section{Rules. \\ 1. Loudon's Rules of Horticulture.}

1. Perform every operation in the proper season and in the best manner.

2. Complete every operation consecutively.

3. Never, if possible, perform one operation in such a manner as to render another necessary.

4. When called off from any operation, leave your work and tools in an orderly manner.

5. In leaving off work, make a temporary finish, and clean your tools and carry them to the tool-house.

6. Never do that in the garden or hothouses, which can be cqually well done in the reserve ground or in the back sheds.

$\tau$. Nerer pass a weed or an insect without pulling it up or taking it off, unless time forbid.

s. In gathering a crop, take away the useless as well as the useful parts.

9. Let no plant ripen seeds, unless they are wanted for some purpose, useful or ornamental, and remove all parts which are in a state of decay.

\section{Rules of Nomenclature.}

1. RULES FOR NAMING FRUITS,

Adopted by the American Pomological Society:

1. The originator or introducer (in the order named) has the prior right to bestow a name upon a new or unnamed fruit.

2. The society reserves the right, in case of long, inappropriate, or otherwise objectionable names, to shorten, modify or wholly change the same when they shall occur in its discussions or reports; and also to recommend such names for general adoption. 
Rules of Nomenclature, continued.

3. The names of fruit should, preferably, express as far as practicable by a single word the characteristics of the variety, the name of the originator, or the place of its origin. Under no ordinary circumstances should more than a single word be employed.

4. Should the question of priority arise between different names for the same variety of fruit, other circumstances being equal the name first publicly bestowed will be given preference.

\section{RULES FOR NAMING KITCHEN-GARDEN VEGETABLES,}

As adopted by the committee on nomenclature of the Association of American Agricultural Colleges and Experiment Stations:

1. The name of a variety shall consist of a single word, or at most of two words. A phrase, descriptive or otherwise, is never allowable; as Pride of Italy, King of Mammoths, Earliest of All.

2. The name should not be superlative or bombastic. In particular, such epithets as Niew, Large, Giant, Fine, Selected, Improved, and the like, should be omitted. If the grower or dealer has a superior stock of a variety, the fact should be stated in the description immediately after the name, rather than as a part of the name itself ; as, "Trophy, selected stock."

3. If a grower or dealer has secured a new select strain of a well-known variety it shall be legitimate for him to use his own name in connection with the established name of the variety; as Smith's Winnigstadt, Jones's Cardinal.

4. When personal names are given to varieties, titles should be omitted; as, Major, General, ete.

5. The term hybrid should not be used except in those rare instances in which the variety is known to be of hybrid origin.

6. The originator has the prior right to name the rariety, but the oldest name which conforms to these rules should be adopted.

7. This committee reserves the right, in its own publications, to revise objectionable names in conformity with these rules.

3. WORK OF THE SOCIETY OF AMERICAN FLORISTS.

This society adopted a resolution demanding reform in names of ornamental plants, at the meeting of 1588 , and a committee was appointed. Definite reform has not yet been inaugurated, however, except in matters of synonymy. 


\section{Rules for Exhibition.}

\section{AMERICAN POMOLOGICAL SOCIETY RLLES.}

\section{For Exhibitors.}

1. A plate of fruit must contain six specimens-no more, no less-except in the case of single varieties not included in collections.

2. To insure examination by the proper committees, all fruits must be correctly and distinctly labeled, and placed upon the tables during the first day of the exhibition.

3. The duplication of varieties in a collection will not be permitted.

4. In all cases of fruits intended to be examined and reported by committees, the name of the exhibitor, together with a complete list of the varieties exhibited by him, must be delivered to the secretary of the society on or before the first day of the exhibition.

5. The exhibitor will receive from the secretary an entry-card which must be placed with the exhibit, when arranged for exhibition, for the guidance of committees.

6. All articles placed upon the tables for exhibition must remain in charge of the society till the close of the exhibition, to be removed sooner only upon express permission of the person or persons in charge.

7. Fruits or other articles intended for testing, or to be given away to visitors, spectators or others, will be assigned a separate hall, room or tent, in which they may be dispensed at the pleasure of the exhibitor, who will not, however, be permitted to sell and deliver articles therein, or to call attention to them in a boisterous or disorderly manner.

\section{For the Guidance of Examining and Auarding Committees.}

1. In estimating the comparative values of collections of fruits, committees are instructed to base such estimates strictly upon the varieties in such collections which shall have been correctly named by the exhibitor prior to action thereon by the committee on nomenclature.

2. In instituting such comparison of values, committees are instructed to consider: 1st, the values of the varieties for the 
Rules for Exhibition (Am. Pom. Society), continued.

purposes to which they may be adapted; 2nd, the color, size, and evenness of the specimens; $3 \mathrm{rd}$, their freedom from the marks of insects and from other blemishes ; 4th, the apparent carefulness in handling, and the taste displayed in the arrangement of the exhibit.

\section{MASSACHUSETTS HORTICULTURAL SOCIETY RULES.}

Special Rules of the Fruit Committee.-1. All collections and single dishes of fruit offered for prizes at any exhibition must have marked upon the cards the numbers of the prizes for which they are offered.

2. All fruits offered for premiums must be correctly named. Indefinite appellations, such as "Pippin," "Sweeting," " Greening," etc., will not be considered as names.

3. All fruits offered for premiums must be composed of exactly the number of specimens or quantity named in the schedule. A "dish" of apples, pears, peaches, plums, nectarines, quinces, figs, apricots, etc., is understood to contain twelve specimens, and this number will be required of all fruits when not otherwise specified.

4. The whole quantity required of any one variety of fruit must be shown in a single dish or basket.

5. Contributors of fruits for exhibitions or prizes must present the same in the Society's dishes. All small fruits must be shown in baskets, not more than an inch and three-quarters in depth, which will be furnished to the exhibitors by the superintendent, at cost. Market-baskets will not be allowed on the tables.

6. No person can compete for more than one prize with the same variety or varieties of fruit, except that a single dish may be of the same variety-but not the same specimens-as one of a collection; and also that the same variety-but not the same specimens-may compete for both special and regular prizes.

7. Grapes grown on girdled vines cannot compete for a premium.

8. All fruits offered for prizes [exceptions noted], and those for foreign grapes must be of outdoor culture.

The Fruit Committee, in making their awards, will consider the flavor, beauty and size of the specimens, comparing each of these properties with a fair standard of the variety. The 
Rules for Exibition (Mass. Hort. Society), continued.

adaptation of the variety to general cultivation will also be taken into account. Other things being equal, specimens most nearly in perfection as regards ripeness will have the preference.

Special Rules of the Vegetable Committee.-1. The specimens offered must be well-grown, and placed on the tables clean, correctly labeled, and fully complying with the Rules and Regulations of the Society.

2. Special gratuities will be awarded for well-grown varieties from under glass, previous to the opening exhibition.

3. All vegetables offered for premiums must be composed of exactly the number of specimens or quantity named in the schedule.

4. All vegetables offered for premiums at any exhibition must have marked upon the cards the numbers of the prizcs for which they are offercd.

5. Prizes will not be awarded when the articles are judged unworthy.

6. Non-compliance with the rules will cause the rejection of the articles offered for premium.

Special Rules of the Flower Committee.-1. All named varieties of plants or flowers exhibited for premiums must have the name legibly and correctly written on stiff card, wood, or some other permanent substance; and each separate plant or flower must have its name attached.

2. All plants, flowers, bouquets, designs, etc., offered for prizes at any exhibition, must have marked upon the cards the numbers of the prizes for which they are offered.

3. Plants in pots, to be entitled to prizes, must evince skillful culture in the profusion of bloom, and the beauty, symmetry and vigor of the specimens.

4. All exhibitors not strictly complying with the above rules will bə excluded from competition for premiums.

5. No gratuities will be awarded on other than regular prize days, except for objects of special merit.

\section{MICHIGAN HORTICULTURAL SOCIETY RULES.}

For Exhibitors.-Entries may be made for exhibition without competition; and if worthy, the awarding committee is expected to notice them properly in its reports. 
Rules for Exhibition (Mich. Hort. Society), continued.

No article entered for competition in one class will be permitted to compete for a premium in any other, except as hereinafter expressly provided.

Each entry of collection of fruits must be accompanied by a correct list of the varieties of each class of fruits, named in the order of their maturity as nearly as may be. No premiums will - be awarded in the absence of such list.

Fruits will be valued by committees according to their adaptation to the requirements under which they are entered. A really superior dessert fruit, if entered in a market collection, can only receive credit for its value for the market, as given in the Society's catalogue; and, vice versa, market varieties found in a dessert or family collection must be adjudged by their proper value for family purposes.

A plate of fruit, unless otherwise specified, must contain fire specimens-no more, noless. Of those usually designated "small fruits," the exhibit must be one pint of each variety. Of crabapples and plums, one dozen of each variety. Of dried fruits, one quart of each separate variety or article. Jellies, canned, pickled and preserved fruits may be entered and shown in glass vessels, of such character and capacity as are commonly employed for family or market purposes.

Flowers, plants, evergreens, and such other articles as the fancy of the exhibitor may suggest, may be freely employed in the ornamentation of exhibits, in any manner that shall not essentially interfere with the examinations of committees or the general designs of decoration; and full weight will be given to such ornamentation by the awarding committees in rendering their awards.

The entry-card furnished by the secretary, specifying the class and number of the entry, must in all cases be placed in connection with the articles to which it appertains, as a guide to committees.

Articles when entered, named and arranged for exhibition will thenceforth be strictly under the control of the officers in charge of the exhibition, and neither exhibitors nor spectators will be permitted to handle them, except by permission of the proper officer.

Any exhibitor having been awarded a premium upon an article, and removing the same prior to the close of the exhibition with- 
Rules for Exhibition (Mich. Hort. Society), continued.

out permission of the officer in charge, will by so doing forfeit his right to such premium.

The name of the fruit should in no case appear on the entrycard, except only in the case of single plates or other single articles.

Entry-cards, name-cards, and the cards of the committee on nomenclature, should, for the convenience of awarding committees and other officers, be each of a different color, or otherwise printed in different-colored inks.

Exhibitors will not be parmitted to sell and deliver the articles they may have entered for exhibition, or to bring fruit or any other article for the purpose of sale, on a penalty of forfeiture of all premiums, but such articles must remain in charge of the officers until the close of the exhibition.

Any exhibitor intcrfering with awarding committees while in discharge of their duties, will be held, by so doing, to have forfeited all premiums.

For Awarding Committees.-1. The division superintendent will be a member and clerk of the awarding committee for his division. The remaining members of each committee will be selected with great care from the best horticulturists of this and neighboring states. The names of such persons will not be made public until the time of the fair.

2. Members of the awarding committee are requested to report to the president, at the secretary's office, on or before noon of the second day of the fair, that the places of those failing to report may be supplied.

3 . The president is chairman of the committee on nomenclature; but to expedite the business of correction the superintendent of each division will correct the nomenclature of his division, appealing to the chairman in all doubtful cases, and attaching the committee's card in all cases in which corrections are made.

4. No exhibitor will be permitted to act on a committee in a class in which he shall exhibit for premiums.

5. Members of the awarding committee are requested to report to the president, at the secretary's office, at 1 o'clock P. M. on Thursday, when they will receive their committee books, together with such explanations and instructions as may at the time seem needful. 
Rules for Exhibition (Mich. Hort. Society), continued.

6. Upon conclusion of their labors, not later than the afternoon of Friday, awarding committees will deliver their reports to the president, who will examine them, and in case of insufficiency or omission will return them with instructions. When accepted by the president, they will be delivered to the secretary.

\%. When an exhibit is not deemed worthy of a premium, the committee will withhold the award.

S. A majority of an awarding committee, when present, shall constitute a quorum, and of those present, the first on the list shall act as chairman, unless the committee shall arrange otherwise.

9. Awarding committees, in estimating the comparative values of exhibits, are instructed to base such estimates strictly upon the varieties in such collections that shall be correctly labeled by the exhibitors prior to the corrections of the committee on nomenclature.

10. In awarding premiums upon any and all exhibits of fruits, committees will exclude any and all unlabeled and incorrectly labeled specimens, as well as duplicates, and consider: 1st, the value of the varieties for the required purpose, as given in the Society's Catalogue of Fruits; 2d, the color, size and evenness of the specimens; $3 d$, their freedom from the marks of insects and other blemishes; 4 th, the apparent carefulness in handling and the tastefulncss of the exhibit, recollecting that the gradations of the catalogue call for perfect specimens. These gradations should, therefore, be correspondingly lowered in case of deficiencies or imperfections. A copy of the catalogue will, for this purpose, be furnished to each committee. In grading collections entered for family purposes, the dessert and culinary subcolumns should be consulted, and the gradation expressing the highest value taken. For market, the gradations of the market subcolumn only should be employed.

11. In the case of fruits not named in the catalogue, for the dessert, committees should consider: 1st, quality; $2 \mathrm{~d}$, beauty; 3d, size. For culinary uses: 1st, flaror; 2 d, texture; $3 d$, size. For market: 1st, productiveness: 2d, color; 3rd, handling qualities: 4th, suitable, even size. 
Rules for Exhibition (Mich. Hort. Society), continued.

12. The true and legitimate purpose of the premiums offered is to draw out the views of both exhibitors and committees respecting the relative values, for the purposes specified, of the varieties included in the exhibits.

13. The society desires to encourage the planting of only a sufficiently large variety of sorts for the desired purpose. Hence it is important that the committee, in their reports, specify, in the order of their value, the varieties upon which the determination of their awards is based.

14. Useful and valuable varieties only are expected to influence awards; while indifferent sorts, even though large, showy and attractive, should not for these reasons alone be held to add to the value of an exhibit, except, possibly, as a means of education.

15. An important object of the society is to collect valuable information of a pomological character. Committees are therefore requested to gather all the information possible from the exhibitors in their classes, and to make their reports as full as time and circumstances will permit.

16. The society desires to foster a free exercise by exhibitors of the principles of correct taste in the arrangement, display and ornamentation of their exhibits. To this end, committees will give all reasonable and proper consideration to particulars of this character.

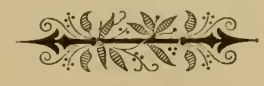

If I could put my words in song,

And tell what's there enjoyed, All men would to my garden tbrong,

And leave the cities roid. 


\section{CHAPTER XVII.}

\section{Postal Rates and Regulations. \\ 1. Classes of Domestic Mail Matter, and Rates.}

First Class.-Letters, postal cards, and matter wholly or partly in writing, whether sealed or unsealed (except manuscript copy accompanying proof-sheets or corrected proof-sheets of the same), and all matter sealed or otherwise closed against inspection.

Rate.-Two cents per ounce or fraction thereof. Postal cards, one cent each. On "drop" letters, two cents per ounce or fraction thereof, when mailed at letter-carrier office; and one cent per ounce or fraction thereof at other offices.

Second Class.-Newspapers and publications issued at stated intervals as often as four times a year, bearing a date of issue and numbered consecutively, issued from a known office of publication, and formed of printed sheets, without board, cloth, leather or other substantial binding. Such publications must be originated and published for the dissemination of information of a public character, or deroted to literature, the sciences, art, or some special industry. They must have a legitimate list of subscribers, and must not be designed primarily for advertising pur- . poses, or for free circulation at nominal rates.

Rate.-One cent per pound or fraction thereof when sent by publisher thereof and from office of publication, including sample copies, or when sent from news agency to actual subscribers or other news agents.

One cent for each four ounces or fraction thereof on newspapers and periodical publications of second class, when sent by other than publisher or news agent.

One cent each on newspapers (excepting weeklies) and peri( 150$)$ 
Classes of Domestic Mail Matter, and Rates, continued.

odicals not exceeding two ounces in weight, when deposited in letter-carrier office for delivery by carrier; two cents each on periodicals weighing more than two ounces.

One cent per pound on newspapers, other than weeklies, and periodicals when deposited by publisher or news agent in lettercarrier office for general or box delivery; one cent for four ounces or fraction thereof when deposited by other than publishers or news agents, for general or box delivery.

One cent per pound or fraction thereof on weekly newspapers deposited by publisher or news agent in letter-carrier office for letter or box delivery, or delivery by carrier; one cent for each package not exceeding four ounces, and one cent for each aditional four ounces or fraction thereof when deposited by other than publisher or news agent.

Free when one copy is sent to each actual subscriber residing in county where same are printed, in whole or in part, and published; but at rate of one cent per pound when delivered at lettercarrier office, or distributed by carriers.

Third Class.-Books, periodicals and matter wholly in print (not included in second class), proof-sheets, corrected proofsheets, and manuscript accompanying the same.

"Printed matter" is the production upon paper, by any process except that of handwriting, of any words, letters, characters, figures, or images, or of any combination thereof, not having the character of an actual and personal correspondence.

A "circular" is a printed letter, which, according to internal evidence, is being sent in identical terms to several persons. It - is permissible to write, in circulars, the date, the name of the person addressed, or of the sender, and to correct mere typographical error's.

Rate.-One cent for each two ounces or fraction thereof.

Foтrth Class.-Merchandise; namely, all matter not embraced in the other three classes, and which is not in its form or nature liable to destroy, deface or otherwise damage the contents of the mail-bag, or harm the person of any one engaged in the postal service, and not above the weight provided by law. Includes seeds and plants. 
Classes of Domestic Mail Matter, and Rates, continued.

Rate.-One cent per ounce or fraction thereof; or on seeds, cuttings, ruots, scions and plants, one cent for each two ounces or fraction thereof.

\section{Foreign Postage.}

To Canada, Newfoundland and Mexico, the rates are the same as domestic postage.

In the Universal Postal Union, which includes nearly all the countries of the world except New Zealand and most Australian provinces, rates are as follows:

Letters, $1 / 2$ ounce ... . . . . . . . . . . 5 cents. Postal cards, each . . . . . . . . . . . . . 2 . . . . . . .

Newspaper and other printed matter, pər 2 ounces . . . 1 "

Commercial papers. $\left\{\begin{array}{l}\text { Packets not in excess of } 10 \text { ounces } 5 \text { " } \\ \text { Packets in excess of } 10 \text { ounces, for } \\ \text { each } 2 \text { ounces or fraction there- } \\ \text { of . . . . . . . . . . 1 } 1\end{array}\right.$

Samples of merchandise. $\left\{\begin{array}{c}\text { Packets not in excess of } 4 \text { ozs. } 2 \text { " } \\ \text { Packets in excess of } 4 \text { ounces, } \\ \text { for each } 2 \text { ounces or frac- } \\ \text { tion thereof . . . . . 1 " }\end{array}\right.$

Registration fee on letters or other articles . . . . . 10

The rates to New Zealand, New South Wales, Queensland, Victoria and Tasmania are: 12 cts. (per $1 / 20 z$.) on first-class matter, 2 cents a copy for newspapers, 4 cents for single rate (4 oz.) on printed matter other than newspapers and merchandise. Rates to China are 13 cents for a half ounce of first-class matter. 5 cents for a single rate $(4 \mathrm{oz}$.) on newspapers, 4 cents for a single rate $(2 \mathrm{oz}$.) on other printed matter and merchandise. For Cape Colony, Natal, most of Morocco, and some other parts of Africa, and some islands, the rate is 15 cents on a half ounce of first-class matter. For Cape Colony and Natal, newspapers demand 4 cents for a single rate $(4 \mathrm{oz}$.), and other printed matter and merchandise 5 cents for a single rate $(2 \mathrm{oz}$.).

\section{Unmailable Mat.er.}

Held for Postage.-Domestic matter of first class on which two cents has not been prepaid, and all other domestic matter not fully prepaid. 


\section{Onmailable Matter, continued.}

Misdirected.-Matter without address, or so incorrectly, insufficiently or illegibly addressed that it cannot be forwarded to destination, including "nixies " or matter not addressed to a postoffice, or addressed to a post-office without the name of the state being given, or otherwise so incorrectly, illegibly or insufficiently addressed that it cannot be transmitted.

Destructive.-Matter of a harmful nature, poisons, explosive or inflammable articles, live animals, or dead animals not stuffed, fruits or vegetable matter liable to decomposition, comb-honey, guano, articles exhaling a bad odor, vinous, spirituous and malt liquors, liquids liable to explosion, spontaneous combustion, or ignition by shock or jar (for example, kerosene oil, naphtha, benzine, turpentine, etc.). Bees and dried insects or reptiles must be so put up as not to injure any one handling the mails, nor to soil mail-bags or their contents.

Coin and Jewelry.-Coin, jewelry and other precious articles prohibited by postal treaty from being sent in the mails to foreign countries.

Scurrilous Matter.-Matter upon the envelope or outside cover or wrapper of which, or any postal-card upon which, any delineations, epithets, terms, or language of an indecent, lewd, lascivious, obscene, libelous, scurrilous, defamatory or threatening character, or calculated by the terms, or manner or style of display, and obviously intended to reflect injuriously upon the character or conduct of another, may be written or printed, or otherwise impressed or apparent.

Obscene Matter.-Every obscene, lewd or lascivious book, pamphlet, picture, paper, letter, writing, print or other publication of an indecent character, and every article or thing designed or intended for the prevention of conception or procuring of abortion, and every article or thing intended or adapted for any indecent or immoral use, and every written or printed card, letter, circular, book, pamphlet, advertisement, or notice of any kind giving information, directly or indirectly, where or how or of whom or by what means any of the hereinbefore-mentioned matters articles or things may be obtained or made, whether sealed as first-class matter or not.

Lottery Matter.-Letters and circulars known to be concerning 
Unmailable Matter, continued.

lotteries, gift-concerts, etc., or concerning any scheme devised and intended to receive and defraud the public for the purpose of obtaining money under false pretenses.

Mutilated.-Matter recovered from wrecked or burned mailcars or vessels, or matter damaged so that it cannot be forwarded to destination. All matter found loose in the mails, separated from the wrapper, label or envelope containing the address, so that the direction cannot be known; and the matter recorered from depredations on the mails and to be restored to the owners upon due proof of ownership.

Excess of Weight and Size.-Packages of domestic third and fourth class matter, weighing more than four pounds (except single books and official matter emanating from the Departments at Washington), and of foreign matter in excess of weight or size fixed by stipulation of postal treaty.

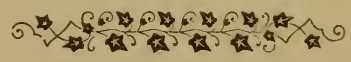

En'n in the stifling bosom of the Town, $\mathcal{H}$ Garien in wbicb notbing tbrives bas cbarms Cbat sootbe the ricb possessor; mucb consoled Cbat bere ans there some sprigs of mournful mint, of nigbtsbaics or valcrian, grace the wall Ilje cultínates. 


\section{CHAPTER XVIII.}

\section{Weather Signs and Protections from Frost.}

Stationary barometer indicates continuance of the present weather.

Slowly rising barometer usually indicates fair weather.

Slowly falling barometer indicates the approach of a severe storm. One-fifth to one-third of an inch is sufficient fall to give indications.

Sudden rise of the barometer indicates the approach of a storm or the breaking-up of an existing storm.

Sudden fall of the barometer indicates high winds and probable rain.

When areas of low and high barometer are near together, heavy gales may be expected.

Long lines of clouds extending up the sky from a common starting-point often fortell a storm from that quarter.

When the fleecy or cirrus clouds settle down into horizontal bars or ribs in the upper sky, wet and foul weather may be expected. This is the "mackerel sky."

If contiguous clouds move in various directions, rain is likely to follow soon.

When small black clouds scud over an overcast sky, heavy rain and bad weather may be expected.

Cumulus clouds that preserve a well-rounded form and float high in the air indicate fair weather.

Anvil-shaped cumulus clouds usually indicate thunder-storms.

In spring and fall, rain is often indicated by a dense bank of gray clouds in the east, in front of which are little shoals of blackish clouds.

Cirro-cumulus clouds-like bunches and fleeces of wool scattered high in the sky-are indications of still and dry weather. 
When the rays of the rising sun shoot far up into the sky, fair weather may be expected.

When the ray-like shadows of clouds overlie a hazy sky in the vicinity of the sun, rain is apt to follow. This is expressed in the phrase "the sun drawing water."

Gaudy hues of blue and purple at sunset prophesy rain and wind.

A bright red sunset means fair weather for the morrow.

A pale and diffuse sun at setting portends a storm.

If the sun sets in subdued purple and the zenith is pale blue, fair weather may be expected.

A deep red morning sky is usually followed by bad weather.

A rosy or gray morning sky means good weather.

A sonorous condition of the atmosphere foretells rain.

A bank of cloud across the southern horizon in winter indicates snow. It is frequently called the "snow-bank."

If the sun rises clear but becomes overcast within half an hour, prepare for rain.

A halo about the moon indicates a rain-storm.

If the sky is white or yellowish white nearly to the zenith after sunset, prepare for rain soon.

Strong east winds indicate a storm.

Haziness is indicative of dry weather. It is due to dust in the atmosphere.

When haziness suddenly dissappears and the sun sets pale and the sky is very clear, rain is probable.

When stars twinkle with unusual prominence, rain may be expected.

Heavy dew indicates fair weather.

Absence of dew for two or three mornings in succession in summer is a precursor of rain.

To Predict Frost (Kedzie) :

1. When the sunshine is very hot and the shade very cold and the shadows very deep, "there is frost in the air," because the air is very dry and radiation of heat little checked.

2. When the dew-point is more than $10^{\circ} \mathrm{F}$. above frost-point, there is little danger of frost. To find approximately the temperature of dew-point when the temperature of the air is between 


\section{Weather Signs, and Protection from Frost. 157}

$45^{\circ}$ and $65^{\circ} \mathrm{F}$., multiply the difference between the wet-bulb and dry-bulb thermometers by two and subtract the product from temperature of dry-bulb. If the remainder is above $42^{\circ} \mathrm{F}$., there is little danger of frost. The nearer this remainder comes to $32^{\circ}$, the greater the danger of frost, especially if the air is still and clouds disappear at sunset.

To Protect Plants from Light Frosts:

1. Make a smudge in the garden or vineyard at night when the frost is expected. Rubbish or litter and tar make the best smudge.

2. Syringe the plants thoroughly at night-fall.

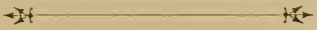

Learn we of the winds, and the weatber's changeful face, And what the ancestral baunts and babits be Of things that grow:-the loved of every place, And the rejected. 


\section{CHAPTER XIX.}

\section{Collecting and Preserving.}

\section{Collecting and Preserving Plants.}

Collect samples of all parts of the plant, lower and upper leaves, stem, flowers, fruit, and in most cases roots. In small species, those two feet high or less, the whole plant should bs taken. Of larger plants, take portions about a foot long. Press the plants between papers or "driers." These driers may bə any thick porous paper, as blotting-paper or carpet-paper, or, for plants that are not succulent or very juicy, newspapers in several thicknesses may be used. It is best to place the specimens in sheets of thin paper-grocer's tea-paper is good-and place these sheets between the driers. Many specimens can be placed in a pile. On top of the pile place a short board and a weight of $20 \mathrm{or} 30$ pounds. Change the driers every day. The plants are dry when they become brittle and when no moisture can be felt by the fingers. Some plants will dry in two or three days, while others require as many weeks. If the pressing is properly done the specimens will come out smooth and flat, and the leaves will usually be green, although some plants always turn black in drying.

Specimens are usually mounted on single sheets of white paper of the stiffness of very heavy writing-paper or thin Bristol board. The standard size of sheet is $11 \frac{1}{2} \times 16 \frac{1}{2}$ inches. The plants may be pasted down permanently and entirely to the sheet, or they may be held on by strips of gummed paper. In the former case, Denison's fish-glue is the best gum to use. But one species or variety should be placed on a sheet. The species of a genus are collected into a genus cover. This cover is a folded sheet of heavy manila or other firm paper, and the standard size, when folded, is $12 \times 16 \frac{1}{2}$ inches. On the lower left hand corner of this 
Collecting and Preserving Plants, continued.

corer the name of the genus is written. A labil should accompany each specimen upon the soparate shects. The specimens are now ready to be filed a way on shelves in a horizontal position. If insects attack the specimens, they may be destroyed by fumcs of bisulphide of carbon (sue p. 9) or chloroform. In this case it is necessary to place the specimens in a tight box and then insert the liquid. Usually, however, specimens are dipped in poison, and then dried before beiug mounted.

Herbarium Poisons.-1. 120 grains of arsenic acid dissolved in il quart of alcohol. The arsenic acid is very deliquescent and the bottle must be kept tightly corked. This is Dr. Gray's farorite preparation, and is used in the herbarium at Harvard University.

2. Place as much corrosive sublimate in alcohol as the liquid will dissolre. If the poison is applied with a brush, care must bo taken to avoid one with iron trimmings, as the sublimate corrodes the iron.

3. Dissolve $13 / 4 \mathrm{oz}$. of corrosive sublimate in $1 \mathrm{pt}$. of alcohol: add $2 \frac{1}{2}$ fluidrachms of carbolic acid and apply with a paint-brush.

t. $1 \mathrm{lb}$. of crrrosive sublimate, $1 \mathrm{lb}$. of carbolic acid to 4 gals. of methylated spirit.

Camphor, frequently renewed in each cabinet, is often suffieient to prevent the attack of insects.

\section{Preserving and Printing of Flowers and Other Parts of Plants.}

To Preserve the Colok of Dried Flowelis.-1. Immerse the stem of the fresh specimen in a solution of $3: 3$ parts by weight of alum, 4 of niter and 186 of water for two or three days until the liquid is thoroughly absorber, and then press in the ordinary way, except that dry sand is sifted over the specimen and the packet submitted to the action of gentle heat for twenty-four hours.

2. Make a varnish composed of 20 parts of powdered copal and 500 parts of ether, powdered glass or sand being used to make the copal dissolve more readily. Into this solution the plants are carefully dipped; then they are allowed to dry for 10 minutes, and the same process is repeated four or tive times in succession. 
Preserving and Printing Flowers and Plants, continued.

3. Plants may also bs plunged in a boiling solution of 1 part of salicylic acid and 600 of alcohol, and then dried in bibulous paper. But this should be done very rapidly, violet flowers especially being decolorized by more than an instantaneous immersion.

4. Red flowers which hare changed to a purplish tint in drying may have their color restored by laying them on a piece of paper moistened with dilute nitric acid (1 part to 10 or 12 parts of water), and then submitting them to moderate pressure for a few seconds; but the solution must not touch the green leares, as they are decolorized by it.

5. With Sulphur. (Quin.) Procure a chest about 3 or $4 \mathrm{ft}$. square, with a small opening in the under part of one side, to be closed by a bar, through which the basin containing brimstone must be put into the chest; this opening must be covered inside with perforated tin, in order to prevent those flowers which hang immediately over the basin from being spoiled. Paper the inside to render it air-tight. When the chest is ready for use, nail small laths on two opposite sides of the interior, at a distance of about 6 inches apart, and on these lay thin round sticks upon which to arrange the flowers; these should not be too close together, or the vapor will not eireulate freely through the vacant spaces around the flowers. When the chest is sufficiently full of flowers close it earefully, place a damp eloth on the sides of the lid, and some heary stones upon the top of it; then take small pieces of brimstone, put them in a small flat basin, kindle and put through the opening in the bottom of the chest and shut the bar. Leave the chest undisturbed for twenty-four hours, after which time it must be opened, and if the flowers be sufficiently smoked they will appear white, if not, they must be smoked again. When sufficiently smoked, take the flowers out carefully and hang them up in a dry, airy place in the shade, and in a few days or even hours they will recover their natural color, except being only a shade paler.

To give them a very bright and shining color, plunge them into a mixture of 10 parts of cold water and 1 of good nitric acid; drain off the liquid, and hang them up again the same as before. The best flowers for this process are asters, roses, fuchsias (single ones), spiræas (red-flowered kinds, such as callosa, Douglasi, etc.), ranunculus, delphiniums, cytisus, etc. The roses should be quite open, but not too fully blown. 
Preserving and Printing of Flowers and Plants, continued.

6. In Sand. (Quin.) Dry the plants in elean silver sand, free from organic matter (made so by repeated washing, until the sand ceases to discolor the water). Heat the sand rather high and $\mathrm{mix}$ with it by constant stirring a small pieee of wax candle, which prevents the sand from adhering to the flowers. Have a box not higher than 3 inches but as broad as possible; this box should have instead of a bottom a narrow-meshed ironwire net at a distance of $3 / 4$ inches from where the bottom should be. Place the box on a board and fill with sand till the net is just covered with a thiu, layer of sand; upon this layer of sand place a layer of flowers, on that a layer of sand, then flowers, and so on; the layers of sind should vary in thickness acrording to the kind of flowers, from $1 / 8$ inch to $1 / 4$ inch.

When the box contains about three layers of flowers, it must be removed to a very sumny dry place, the best being close under the glass in an empty greenhouse, exposed to the full influence of the sun. After a week, if the weather is sunny and dry, the flowers will be perfectly dried; then the box is lifted a little, the sand falls gently through the iron net, and the flowers remain in their position over the net without any disturbance whatever.

They should then be taken out carefully and kept in a dry and, if possible, dark place, where no sun can reach them, and afterwards they will keep very well for many years.

Care should be taken that the flowers are cut in dry weather and that while lying in the sand no part of a flower shall touch another part, as this always spoils the color and eauses decay. Sand should be filled in between all the parts of the flower; therefore it is necessary to insert the double flowers in an erect position, in order to fill the sand between the petals, while most of the single flowers must be put in with the stalks upwards.

To Keep Fresh Flowers.-If cut-flowers are not needed immediately, wet them and then wrap them in paper and place in a box in a cool place. Keep as cool as possible without freezing.

The disagreeable odor which comes from flowers in vases is due to the decay of the leaves and stems in the water. Therefore remove all the lower leaves before putting flowers in vases. 


\section{Preserving and Printing of Flowers and Plasts, continued.}

Flowers that have stood in a rase for a day or so can be greatly refreshed if taken from the vase at night, thoroughly sprinkled and wrapped, stems, blossoms and all, as closely as possible in a soaked cloth, and laid aside until the morning. They will be much fresher than if they had been left in their vases, yet will not have bloomed out so much. Before thus laying them aside, and again in the morning, a bit of each stem should be cut off, as the end soon hardens. This ought also to be done once or twice a day, even if the flowers are kept constantly in their vases. Roses which have drooped before their time-as, for example, when worn on the dress-may be wonderfully revived if the stems, after being thus cut, are placed for ten minutes in almost boiling water and then removed to cold water. It is also well to add a little charcoal or ammonia to the water in which flowers are standing.

If salt is added to the water in which cut-flowers are kept, it will delay wilting and decay.

Printing Plants.-1. First, lightly oil one side of the paper, then fold in four, so that the oil may filter through the pores, and the plant may not come into direct contact with the liquid. The plant is placed between the leaves of the socond folding, and in this position pressed (through other paper) all over with the hand, so as to make a small quantity of oil adhere to its surface. Then it is tiken out and placed between two sheets of white paper for two impressions, and the plant is pressed as before. Sprinkle over the invisible image remaining on the paper a quantity of black-lead or charcoal, and distribute it in all directions; the image then appears in all its parts. With an assortment of colors the natural colors of plants may be reproduced. To obtain fixity, rosin is previously added to the black-lead in equal parts. Expose to heat sufficient to melt the rosin.

2 . The best paper to use is ordinary wove paper without watermarks; if it can be afforded, use thin drawing-paper. First select the leaves, then carefully press and dry them. If they be placed in a plant-press, care must be taken not to put too great pressure on the specimens at first, or they will be spoiled for printing. An old book is the best for drying the samples to be used. Take printers' or proof ink, and a small leather dabber; 
Preserving and Printing of Flowers and Plants, continued.

work a bit of ink about the size of a pea on a small piece of slate or glass with the dabber until it is perfectly smooth. A drop or two of linseed-oil will assist the operation. Then give the leaf a thin coating, being careful to spread it equally; now lay the leaf ink downwards on a sheet of paper and place it between the leaves of an old book, which must then be subjected to a moderate pressure in a copying-press, or passed between the rollers of a wringing-machine. Impressions can be taken with greater rapidity by laying the book on the floor and standing upon it for a few seconds. Soft book-paper is the best. Previous to using it, place a few sheets between damp blotting-paper, which causes it to take the ink still more readily. At first you will find that you lay on too much ink. If the impression is too black, use the leaf again. If the midrib of the leaf is too thick, it must be shaved down with a sharp knife.

3. Leaf-Prints. (Engle.) 1. A small ink-roller, such as printers use for inking type. 2. A quantity of green printers' ink. 3. A pane of stout window-glass (the larger the better) fastened securely to an evenly planed board twice the size of the glass. A small quantity of the ink is put on the glass and spread with a knife, after which it is distributed evenly by going over in all directions with the ink-roller. When this has been carefully done, the leaf to be copied is laid on a piece of waste paper and inked by applying the roller once or twice with moderate pressure. This leaves a film of ink on the veins and network of the leaf, and by placing it on a piece of blank paper and applying considerable pressure for a few moments the work is done, and when the leaf is lifted from the paper the impress remains with all its delicate tracery, faithful in color and outline to the original.

To make the ink of proper consistency, add several drops of balsam copaiba to a salt-spoonful of ink. In case the leaf sticks, the ink is too thick.

Skeletonizing Plaxts. 1. By Maceration. Place the leaves in water and allow them to remain in the same water for from three to four months, until the soft matter decays, and the stem may be taken in the hand and the refuse shaken away. There remains behind a network or skeleton of the original object, 
Preserving and Printing of Flowers and Plants, continued.

which can be bleached with a little lime. Leares and pods may both be treated satisfactorily in this manner. The pod of the "Jimson weed" or Datura Stramonium is a favorite for this purpose.

2. By Chemicals. Chloride of lime, $1 / 4$ lb. ; washing soda, $1 / 2 \mathrm{lb}$. Put the soda into $1 \frac{1}{2}$ pts. boiling water (rain-water is best) and let it thoroughly dissolve. Put the chloride of lime in a large pitcher, and add same quantity of cold water. Stir well and cover closely to prevent the escape of the chlorine. When the soda-water is cool, pour it on the chloride of lime, stir well together and cover tightly, leaving it for an hour or more. Then pour off very gently the clear liquid, which must be bottled tightly.

This solution will remove fruit-stains from white goods, and will bleach any regetable substances. When used for cotton or linen, it must be considerably diluted, and the goods well rinsed afterwards.

\section{Perfumery.}

Permanent Attar or Otto of Roses. (Ellwanger.)-The roses employed should be just blown, of the sweetest-smelling kinds, gathered in as dry a state as possible. After each gathering, spread out the petals on a sheet of paper and leare until free from moisture; then place a layer of petals in the jar, sprinkling with coarse salt; then another layer of coarse salt alternating until the jar is full. Leave for a few days, or until a broth is formed; then incorporate thoroughly and add more petals and salt, mixing thoroughly daily for a week, when fragrant gums and spices should be added, such as benzoin, storax, cassia-buds, cinnamon, cloves, cardamon and vanilla-bean. Mix again and leave for a few days, when add essential oil of jasmine, violet, tuberose and attar of roses, together with a hint of ambergris or musk, in mixture with the flower ottos, to fix the odor. Spices, such as cloves, should be sparingly used.

Perfume JAR. - 1 . One $1 \mathrm{~b}$. of dried rose-petals bought at a drug-store, 4 ozs. of salt and 2 ozs. of saltpeter, on which put 8 drops of essence of ambergris, 6 drops of essence of lemon, 4 drops of oil of cloves, 4 drops oil of lavender and 2 drops of essence of bergamot. 
Perfumery, continued.

2. One - half 1 b. common salt, $1 / 4 \mathrm{lb}$. saltpeter, $1 / 4 \mathrm{oz}$. storax, $1 / 2$ doz. cloves, a handful of dried bay-leaves, and another handful of dried lavender-flowers. This basis will last for years, and petals of roses and other fragrant flowers gathered on dry days may be added annually, or powdered benzoin, chips of sandalwood, cinnamon, orris-root or musk may be added.

LaVexner Bag.-One-half lb. lavender-flowers, $1 / 2$ oz. dried thyme and mint, $1 / 4 \mathrm{oz}$. ground cloves and caraway, $1 \mathrm{oz}$. common salt. Tie up in a linen bag, which is hung in a wardrobe.

Orris-root is a good medium in which to place delicate perfumes for perfumery-bags.

\section{Collecting and Preserving Insects.}

Flying insects are caught in a net made of musquito-bar, after the fashion of the minnow-net. The bar is made into a bag about a yard deep, and about a foot in width at the top. The opening is fastened upon a wire hoop, which is secured to a poleas a broomstick. Insects are killed by placing them in a "cyanide-bottle." This is prepared by placing two or three lumps of cyanide of potassium the size of a quail's egg in a museum-bottle or glass jar, covering the lumps with dry plaster of Paris, and then adding just enough water to make the plaster set. The fumes of the poison coming through the plaster quickly kill the insects. Keep the bottle corked. The cyanide is very poisonous and the fumes should not be inhaled. A very broadmouthed bottle with glass stopple is best. Bugs and beetles can be pinned and mounted as soon as they are dead. It is customary to pin beetles through the right wing-cover, and bugs-as squash-bug-through the triangular space between the wings. Butterflies, moths, bees, flies, etc., must be pressed to preserve the wings. This is done by placing on a "setting-board." This apparatus is a little trough with a crack at the bottom. The sides of the trough are made of thin bits of board, three or four inches wide and a foot or more long. These sides have very little slant. The crack in the bottom of the trough is left about a half-inch wide, and it is covered beneath with a strip of cork. The body of the insect is now placed lengthwise the crack, a pin is thrust through the thorax, or middle division of the insect, into the cork, and the wings are laid out on the sides of the 
Collecting and Preserving Insects, continued.

trough. The wings are held in place by strips of cardboard pinned over them. Take care not to stick the pins through the wings. In about two weeks the insects will be dry and stiff.

Insects must be kept in tight boxes to keep other insects from devouring them. Cigar-boxes are good. Tight boxes with glass covers are generally used by collectors. Place sheets of cork in the bottom of the box to receive the pins. If insects attack the specimens, expose them in a tight box to vapors of bisulphide of carbon (see p. 9) or benzine.

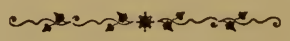

Happy the man whose wish and care

A few paternal acres bound,

Content to breathe his native air

In his own ground.

Whose herds with milk, whose fields with bread,

Whose flocks supply him with attire;

Whose trees in summer yield him shade,

In winter, fire.

Blest, who can unconcern'dly find

Hours, days and years slide soft away

In health of body, peace of mind,

Quiet by day. 


\section{CHAPTER XX.}

Elements, Symbols axd Analyses.

\section{The Elements and their Symbols, and the Composition of Various Substances.}

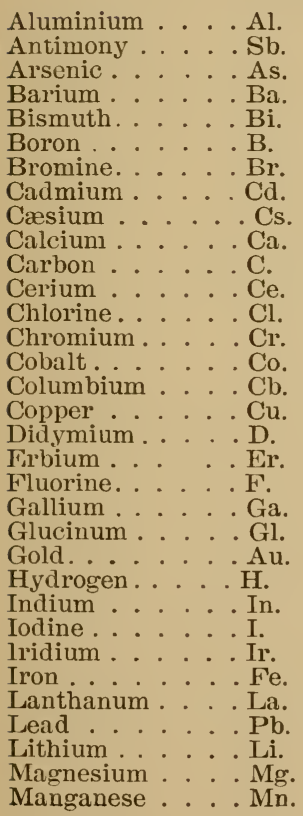

Mercury. . . . Hg.

Molybdenum ... Mo.

Nickel. . . . . Ni.

Nitrogen . . . N.

Osmium ...... Os.

Oxygen ...... O.

Palladium ..... Pd.

Phosphorus .... P.

Platinum ... . Pt.

Potassium . . . K.

Rhodium .... Rh.

Rubidium .... Rb.

Ruthenium . . Ru.

Scandium . . . Sc.

Selenium ... . Se.

Silicon. . . . Si.

Silver ....... Ag.

Sodium ..... Na.

Strontium . . . Sr.

Sulphur ..... S.

Tantalum .... Ta.

Tellurium .... Te.

Thallium ... . Tl.

Thorium . . . . Th.

Tin ..... Sn.

Titaniuni ... Ti.

Tungstep ....W.

Uranium . . . U.

Vanadium .... V.

Yttrium ..... Y.

Zinc .... . Zn.

Zirconium . . Zr. 
The Composition of Irarious Substances.

Acetic acid . . . $\mathrm{C}_{2} \mathrm{H}_{4} \mathrm{O}_{2}$

Ammonia ..... $\mathrm{NH}_{3}$

Aniline ...... $\mathrm{NH}_{2}\left(\mathrm{C}_{6} \mathrm{H}_{5}\right)$

Arsenious oxide . . $\mathrm{As}_{4} \mathrm{O}_{6}$

Carbonic oxide . . CO

Carbonic dioxide. $\mathrm{CO}_{2}$

Chloroform . . . $\mathrm{CHCl}_{3}$

Ferric oxide ... $\mathrm{Fe}_{2} \mathrm{O}_{3}$

Ferrous oxide . . FeO

$\mathrm{Hydrochloric}$ acid. $\mathrm{HCl}$

Mercuric oxide . . HgO
Nitric acid .... $\mathrm{HNO}_{3}$

Nitric oxide . . . NO

Nitrous oxide . . . $\mathrm{N}_{2} \mathrm{O}$

Nitric peroxide . . $\mathrm{NO}_{2}$

Sulphuretted

hydrogen .... $\mathrm{H}_{2} \mathrm{~S}$

Sulphurous oxide. $\mathrm{SO}_{2}$

Sulphuric oxide ... $\mathrm{SO}_{3}$

Sulphuric acid . $\mathrm{H}_{2} \mathrm{SO}_{4}$

Water...... $\mathrm{H}_{2} \mathrm{O}$

\section{Analyses.}

Compiled from many reliable sources, largely from the labors of Drs. Goessmann and S. W. Johnson.

(a.) General Axalyses of Fruits and Fruit-Plants.

1. Various Fruits. (Fresenius.)

\begin{tabular}{|c|c|c|c|c|c|c|}
\hline & $\underset{8}{\stackrel{5}{3}}$ & 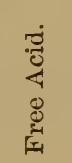 & 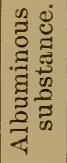 & 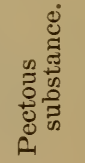 & 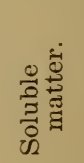 & 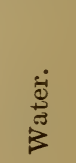 \\
\hline Apples. & 6.83 & .85 & .45 & .47 & 14.96 & S:.04 \\
\hline Apricots . . . . & 1.531 & .766 & .359 & $9.2 \$ 3$ & 12.723 & 82.115 \\
\hline Austrian Grapes . . . & 13.78 & 1.020 & .532 & .498 & 16.49 & \%9.997 \\
\hline CultivatedStrawberies & 7.575 & 1.133 & .359 & .119 & 9.666 & 87.474 \\
\hline Cultivated Raspberries & 4. 708 & 1.356 & .544 & 1.746 & 8.835 & 86.557 \\
\hline Green Grapes: . . . . & 2.96 & .96 & $.4 \%$ & 10.475 & 15.19 & 80.841 \\
\hline Heart-Cherries & 13.11 & .351 & .903 & 2.286 & 17.25 & 75.37 \\
\hline Mulberries. & 9.193 & 1.86 & .394 & 2.031 & 14.043 & $84.70 \%$ \\
\hline Peaches . & 1.580 & .612 & .463 & 6.313 & 9.39 & $\$ 4.99$ \\
\hline Pears.... & 7.00 & .074 & .26 & 3.281 & 10.90 & 83.95 \\
\hline Red Currants... & 4.78 & 2.31 & .45 & .28 & 8.36 & 85.84 \\
\hline Red Gooseberries. & 8.063 & 1.358 & .441 & 9.69 & 11.148 & 85.565 \\
\hline Wild Raspberries. & 3.599 & 1.980 & .546 & $1.10 \tau$ & $\tau .500$ & 83.86 \\
\hline Wild Strawberries . . & 3.247 & 1.650 & .619 & .145 & 6.398 & 87.271 \\
\hline
\end{tabular}


Elements, Symbols and Analyses.

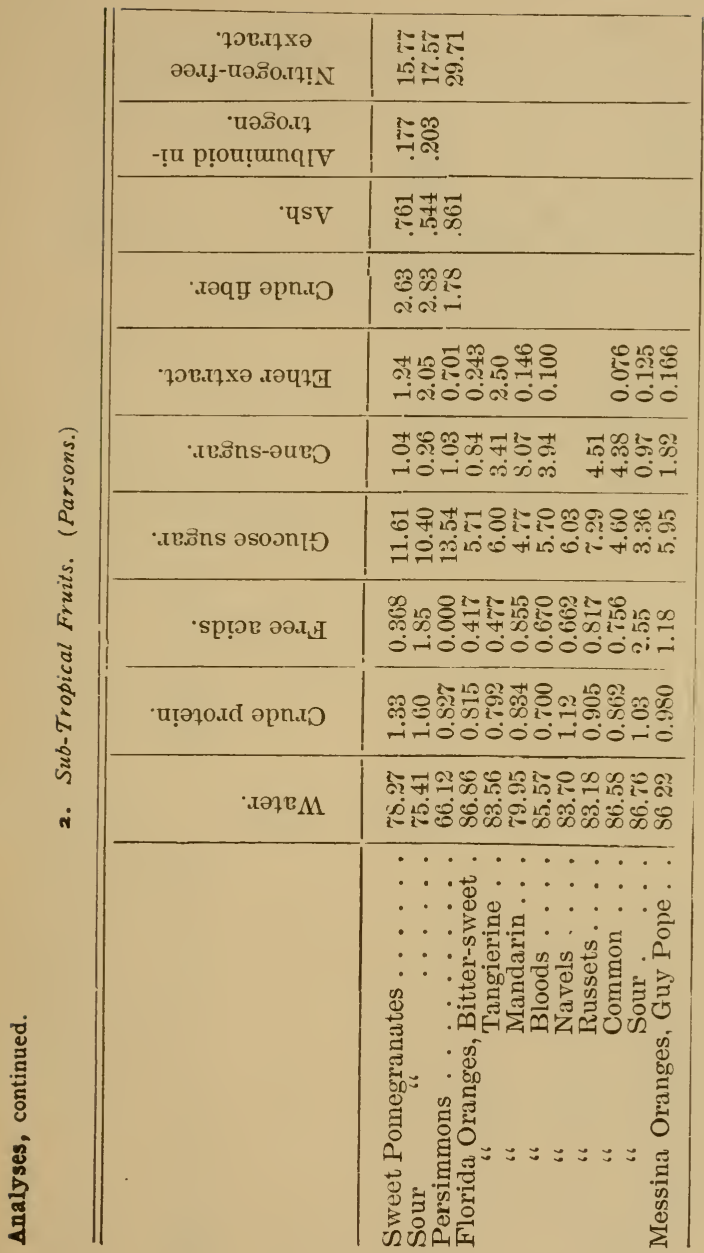


Analyses, continued.

3. Strawberries, Average of 20 Varieties. (Stone.)

Water . . . . . . . . . . 90.52

Solíds . . . . . . . . . . . . 9.45

Free acid. . . . . . . . . . . . 1.37

Glucose ................ 4.78

Glucose after inversion . . . . . . . . 5.46

Difference calculated as cane-sugar . . . . 0.58

COMPOSITION OF DRY AIATTER.

Ash ................ . . 6.53

Crude fiber. . . . . . . . . . 16.35

Ether extract ............ . . 6.75

Crude protein . . . . . . . . . . 10.51

Non-nitrogenous extract. . . . . . . 6079

4. Raspberries. (Weber.)

\begin{tabular}{|c|c|c|}
\hline Sugar & $\begin{array}{l}\text { Reliance. } \\
.1 .78\end{array}$ & $\underset{2.82}{G r e g g}$ \\
\hline & 0.92 & 0.64 \\
\hline & 3.5 & .612 \\
\hline e, protein, combined acids, etc & 3.92 & \\
\hline$\ldots \ldots \ldots \ldots$ & 0.43 & \\
\hline 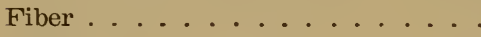 & . 0.32 & \\
\hline er. & 89.13 & \\
\hline
\end{tabular}

5. Peach, Branches. (Kedzie.)

Silica, $\mathrm{SiO}_{2} \ldots \ldots \ldots . . . . .21 .21 \quad 1.40$

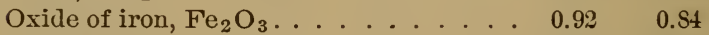

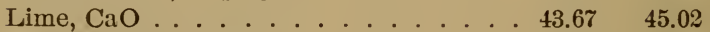

Magnesia, MgO. . . . . . . . . $2.53 \quad 2.40$

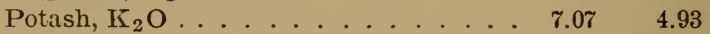

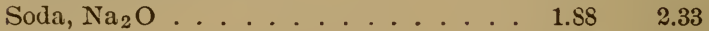

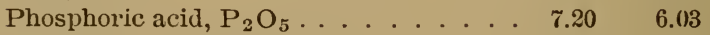

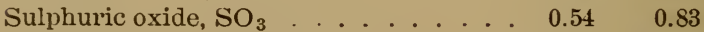

Carbon dioxide, $\mathrm{CO}_{2} \ldots \ldots . \ldots . . .34 .71 \quad 35.85$

Chlorine .............. . . $0.07 \quad 0.11$

Moisture and loss. . . . . . . . . . . . $0.30 \quad 0.26$

Total........... $\overline{100.00} \overline{100.00}$ 
Analyses, continued.

6. Peach, Fruit and Branches. (Goessmann.)

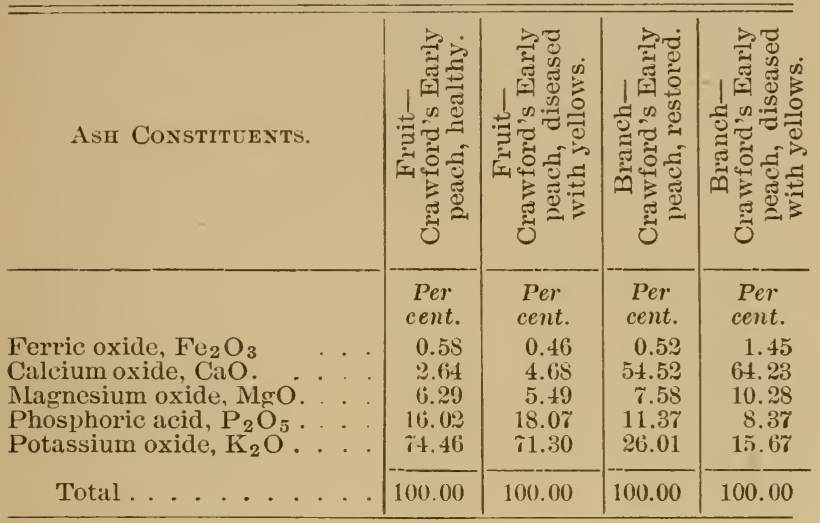

7. Fertilizing Constituents in the Ash of Fruits. (Goessmann.)

Name.

Lombard Plums . . . . . . . . 6.59 . . 13.26

Peaches . . . . . . . . $\pi 4.46 \ldots 2.64$

Baldwin Apples . . . . . . . 63.54

Asparagus, stem . . . . . . 42.94

" roots. . . . . 56.43

Clinton Grapes . . . . . . .57.40

Concord Grapes . . . . . . . 62.29

Cranberries ....... . . $47.96 \quad 6.58 \quad 18.58$

White Currants . . . . . 53.81 . . 17.46

Black Raspberries. . . . . . . 50.00 . . 19.44

Blackberries. . . . . . . . 51.42 . . 17.22

Blueberries .......... 31.36 $\begin{array}{llll}1.71 & 7.28 & 5.52 & 20.87\end{array}$

$\begin{array}{llll}3.58 & 27.18 & 12.77 & 12.31\end{array}$

$\begin{array}{llll}5.42 & 15.48 & 7.57 & 15.09\end{array}$

$\begin{array}{llll}3.51 & 13.10 & 7.24 & 17.87\end{array}$

$\begin{array}{ll}1.76 & 18.49\end{array}$

$6.78 \quad 14.27$

$4.72 \quad 22.54$

$9.60 \quad 20.47$

$\begin{array}{ll}5.30 & 24.13\end{array}$

$9.25 \quad 29.05$ 
(b) Analyses of Fruit and Garden Products with Reference to their Fertilizing Constituents

8. Analysis of Garden Crops and Fruits for Fertilizing Constituents. (Wolff and Goessmann.)

ONE, THOUSAND PARTS OF THE PLANTS CONTAIN:

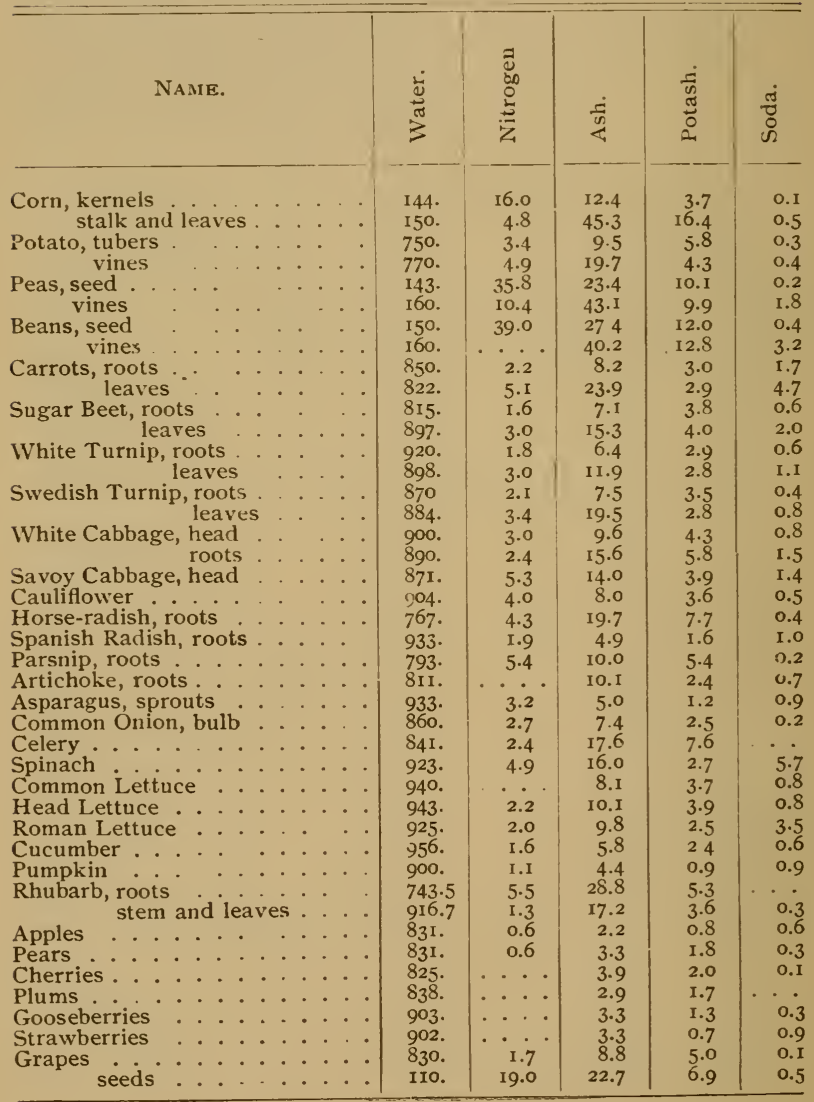


$\Lambda$ nalysis of Garden Crops and Fruits, continued.

ONE THOUSAND PARTS OF THE PLANTS CONTAIN :

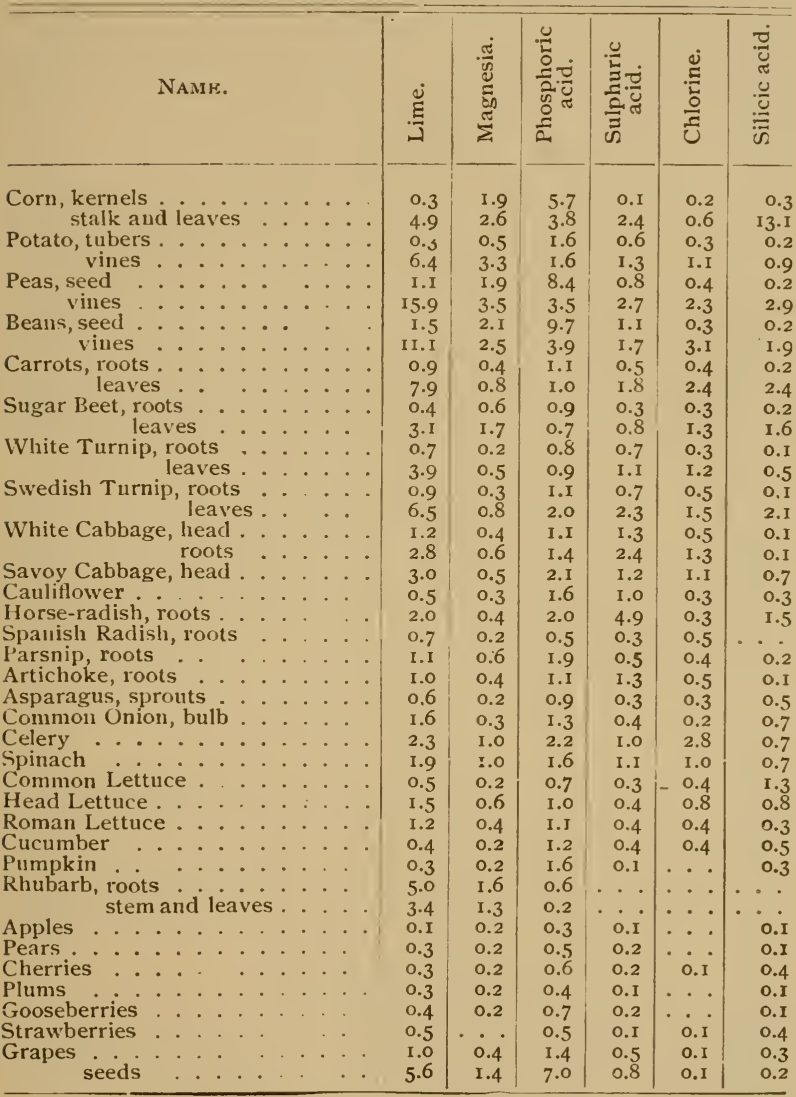


Analyses, continued.

9. Apple-Pomace.

Water. . . . . . . . . . . 69990

Ash . . . . . . . . . . . . . . . . . . . . . .

Albuminoids . . . . . . . . . . . . 1.58

Fiber . . . . . . . . . . . . . . . . 4.87

Nitrogen-free extract . . . . . . . . . . . . 21.24

Fat. . . . . . . . . . . . . . . 1.71

10. Cranberry-Tines.

100.00

Moisture at $100^{\circ}$ C. . . 13.0\% Phosphoric acid. . . . 0.268 Nitrogen . . . . . . 0. 0.7 Magnesium oxide . . . 0.253

Ash constituents . . . 2.45 Sodium oxide . . . . . 0.080

Ferric oxide. . . . . 0.087 Potassium oxide . . . 0.329

Calcium oxide. . . . . 0.404 Insoluble matter . . . . 0.534

11. Corn-Fodder.

Moisture at $100^{\circ}$ C. . . 24.S7 Potassium oxide . . 1.465

Nitrogen . . . . . . 0.995 Sodiumoxide . . . . . 0.794

Phosphoric acid. . . . 0.201 Ferric oxide. . . . 0.026

Calcium oxide. . . . . 0.310 Insoluble matter . . . 1.318

Magnesium oxide . . 0.093

12. Corn-Kernel, New.

Water . . . . . . . . . . . . . 20.00

Ash . . . . . . . . . . . . . . . 1.25

Albuminoids . . . . . . . . . . . . . 8.06

Fiber. . . . . . . . . . . . . . . . 1.54

Nitrogen-free extract . . . . . . . . . . . . . 65.38

Fat. . . . . . . . . . . . . . . . . . . . .

13. Pea-straw.

Potash ................... . . . . . . . . . .

Lime . . . . . . . . . . . . . . . . . . . . . . . . . . . . . . . . . . . . . . .

Magnesia . . . . . . . . . . . . . 6.88

Oxide of iron. . . . . . . . . . . . . . . 0.40

Oxide of manganese . . . . . . . . . . . . . . 0.15

Phosphoric acid . . . . . . . . . . . 4.83 
Analyses, continued.

Sulphuric acid .

Chlorine...................... . . . 0.09

Alumina . . . . . . . . . . . . . . . 1.21

Silica ... . . . . . . . . . . . 20.03

14. Peas.

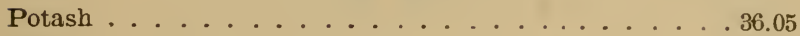

Soda . . . . . . . . . . . . . . . . . . . . . . . . . . . . . . . . . . .

Lime... . . . . . . . . . . . . . . 5.29

Magnesia. . . . . . . . . . . . . . . . . . . 18.46

Oxide of iron. . . . . . . . . . . . . . . . . . . 0.99

Phosphoric acid . . . . . . . . . . . . . . . . . 33.29

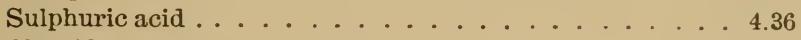

Chloride of sodium . . . . . . . . . . . . 3.13

Silica . . . . . . . . . . . . . . . 0.51

15. Beet, Egyptian Turnip.

Moisture at $100^{\circ}$ C. . . 85.800 Magnesium oxide . . 0.035

Nitrogen . . . . . . 0.177 Sodiumoxide . . . 0.061

Phosphoric acid . . . 0.070 Ferric oxide . . . . 0.002

Potassium oxide . . . 0.303 Insoluble matter . . . 0.018

Calcium oxide . . . 0.049

16. Carrots.

Moisture at $100^{\circ}$ C. . . 90.02 Potassium oxide . . 0.54

Ferric oxide..... 0.01 Sodium oxide . . . . 0.11

Phosphoric acid . . . 0.10 Nitrogen . . . . . 0.14

Magnesium oxide . . . 0.02 Insoluble matter . . . 0.01

Calcium oxide . . . . 0.07

17. Turnip, Ruta-baga.

Moisture at $100^{\circ}$ C. . 87.230 Magnesium oxide . . 0.030

Nitrogen . . . . . . 0.211 Sodium oxide . . . . 0.051

Phosphoric acid . . . . 0.136 Ferric oxide . . . . 0.002

Potassium oxide . . . 0.546 Insoluble matter . . . 0.001

Calcium oxide .... 0.106 
Analyses, continued.

(c.) Axalyses of Aximal Excremexts.

1S. Common Barn-yard Manure, Fresh.

Water. . . . . . 710.0 Lime . . . . . 5. Organic substance . . 246.0 Magnesia . . . . . . 1.4

Ash . . . . . . . 44.1 Phosphoric acid . . . 2.1

Nitrogen . . . . 4.5 Sulphuric acid . . . 1.2

Potash . . . . . . 5.2 Silica and sand . . . 12.5

Soda . . . . . . 1.5 Chlorine and fluorine . . 1.5

19. Common Barn-yard Manure, Moderately Rotted.

Water . . . . . $\tau 50.0$ Lime ......

Organic substance . . 192.0 Magnesia . . . . . 1.8

Ash . . . . . . . . 55.0 Phosphoric acid . . . . 2.6

Nitrogen . . . . . . 5.50 Sulphuric acid . . . 5.6

Potash . . . . . . 6.3 Silica and sand . . . . 16.8

Soda . . . . . . . . 1.9 Chlorine and fluorine . . 1.9

20. Common Barn-yard Manure, Thoroughly Rotted.

Water . . . . . . 790.0 Lime . . . . . . 8.8

Organic substance . . 145.0 Magnesia . . . . . . 1.8

Ash . . . . . . . 65.0 Phosphoric acid . . . 3.0

Nitrogen . . . . . . . $\quad 5.8$ Sulphuric acid . . . . 5.

Potash . . . . . 5.0 Silica and sand . . . 17.0

Soda . . . . . . . 1.3 Chlorine and fluorine . 1.6

21. Cattle-Feces, Fresh.

Water ...... 838.0 Lime . . . . . 3.4

Organic substance ... 145.0 Magnesia ...... 1.3

Ash . . . . . . . 17.3 Phosphoric acid . . . 1.7

Nitrogen . . . . . . 2.9 Sulphuric acid . . . . 0.4

Potash . . . . . 1.0 Silica and sand . . . 7.2

Soda . . . . . . . 0.2 Chlorine and fluorine . 0.2

22. Cattle-Urine, Fresh.

Water . . . . . . 938.0 Lime . . . . . . . 0.1

Organic substance ... 35.0 Magnesia . . . . . . 0.4

Ash . . . . . . . 27.4 Sulphuric acid . . . 1.3

Nitrogen . . . . . . 5.8 Silica and sand . . . . 0.3

Potash . . . . . . . 4.9 Chlorine and fluorine . 3.8

Soda . . . . . . . 6.4 
Analyses, continued.

23. Horse-Feces, Fresh.

Water 757.0 Lime . . . . . . . 1.5

Organic substance . . 211.0 Magnesia . . . . . 1.2

Ash . . . . . . . 31.6 Phosphoric acid . . . . 3.5

Nitrogen . . . . . . 4.4 Sulphuric acid . . . 0.6

Potash . . . . . . 3.5 Silica and sand . . . . 19.6

Soda . . . . . . . 0.6 Chlorine and fluorine . . 0.2

24. Horse-Urine, Fresh.

Water .. . . . . 901.0 Lime ... . . . . 4.5

Organic substance .. 71.0 Magnesia . . . . . 2.4

Ash . . . . . . . . . 28.0 Sulphuric acid . . . . 0.6

Nitrogen . . . . . . 15.5 Silica and sand . . . 0.8

Potash . . . . . . 15.0 Chlorine and fluorine . . 1.5

Soda ......... 2.5

25. Sheep-Feces, Fresh.

Water . . . . . 655.0 Lime . . . . . 4.6

Organic substance .. 314.0 Magnesia . . . . . 1.5

Ash . . . . . . . 31.1 Phosphoric acid . . . 3.1

Nitrogen . . . . . 5.5 Sulphuric acid . . . 1.4

Potash .. . . . 1.5 Silica and sand . . . 17.5

Soda . . . . . 1.0 Chlorine and fluorine . 0.3

26. Sheep-Urine, Fresh.

Water . . . . . . . sт2.0 Lime ........ 1.6

Organic substance ... 83.0 Magnesia . . . . . . 3.4

Ash . . . . . . . 45.2 Phosphoric acid . . . 0.1

Nitrogen . . . . . 19.5 Sulphuric acid . . . 3.0

Potash . . . . . . . 22.6 Silica and sand . . . 0.1

Soda . . . . . . . 5.4 Chlorine and fluorine . 5.5

27. Swine-Feces, Fresh.

Water. . . . . . . \$.20.0 Lime . . . . . . . 0.9

Organic substance . . 150.0 Magnesia . . . . 1.0

Ash . . . . . . . 30.0 Phosphoric acid . . . 4.1

Nitrogen . . . . . 6.0 Sulphuric acid . . . 6.4

Potassh . . . . . . 2.6 Silica and sand . . . 15.0

Soda . . . . . . . 2.5 Chlorine and fluorine . 0.3 
Analyses, continued.

28. Swine-Urine, Fresh.

Water ....... 967.0 Soda ....... 2.1

Organic substance . . 28.0 Magnesia . . . . . . 0.8

Ash . . . . . . . 15.0 Phosphoric acid . . . 0.7

Nitrogen ...... 4.3 Sulphuric acid . . . 0.8

Potash ....... 8.3 Chlorine and fluorine . . 2.3

29. Human Feces, Fresh.

Water . . . . . . 772.0 Lime ........ 6.2

Organic substance . . 198.0 Magnesia . . . . . 3.6

Ash . . . . . . . 29.9 Phosphoric acid . . . . 10.9

Nitrogen . . . . . 10.0 Sulphuric acid ... . 0.8

Potash . . . . . . 2.5 Silica and sand ... . 1.9

Soda . . . . . . 1.6 Chlorine and fluorine .. 0.4

30. Human Urine, Fresh.

Water ....... . 963.0 Lime ....... 0.2

Organic substance .. 24.0 Magnesia ....... 0.2

Ash ........ . 13.5 Phosphoric acid . . . 1.7

Nitrogen . . . . . 6.0 Sulphuric acid . . . 0.4

Potash ...... 2.0 Chlorine and fluorine . 5.0

Soda ....... 4.6

31. Hen-Manure, Fresh.

Water ....... . 560.0 Lime ...... . 24.0

Organic substance .. 255.0 Magnesia . . . . . . 7.4

Ash . . . . . . . 185.0 Phosphoric acid . . . 15.4

Nitrogen ..... . 16.3 Sulphuric acid ... . 4.5

Potash ....... . 8.5 Silica and sand . . . . 35.2

Soda ........ 1.0

32. Goose-Manure, Fresh.

Water ..... . . 771.0 Lime . . . . . . . 8.4

Organic substance . . 134.0 Magnesia . . . . . . 2.0

Ash . . . . . . . 95.0 Phosphoric acid . . . 5.4

Nitrogen ...... 5.5 Sulphuric acid .... 1.4

Potash ........ 9.5 Silica and sand .... 14.0

Soda ........ 1.3 
Analyses, continued.

33. Duck-Manure, Fresh.

Water . . . . . 566.0 Lime . . . . . . . 17.0

Organic substance . . 262.0 Magnesia . . . . . . 3.5

Ash . . . . . . . 172.0 Phosphoric acid . . . 14.0

Nitrogen ...... 10.0 Sulphuric acid . . . 3.5

Potash ....... 6.2 Silica and sand . . . 28.0

Soda . . . . . 0.5

34. Dove-Manure, Fresh.

Water ....... 519.0 Lime ... . . . 16.0

Organic substance . . 308.0 Magnesia . . . . . . 5.0

Ash . . . . . . . . 173.0 Phosphoric acid . . . 17.8

Nitrogen . . . . . 17.6 Sulphuric acid . . . . 3.3

Potash . . . . . . 10.0 Silica and sand . . . 20.2

Soda . . . . . 0.7

(d.) Analyses of Variods Materials which are Used For Fertilizers.

35. Peruvian Guano.

Moisture at $100^{\circ} \mathrm{C}$. . . 12.1\% Total nitrogen . . . . 5.13

Total phosphoric acid . . 1S.45 Actual ammonia . . . . 3.94

Soluble phosphoric acid . 1.54 Organic nitrogen . . . . 0.86

Reverted phosphoric acid 5.92 Nitrogen as nitric acid $\quad 0.33$

Insoluble phosphor ic acid 10.99 Insoluble matter . . . . 13.64

Potassium oxide . . 3.46

36. Oak-Leaves.

Moisture at $100^{\circ}$ C. . . 9.601 Potassium oxide . . . 0.549

Organic matter . . . $\$ 3.360$ Phosphoric acid . . . 0.055

Minera1 matter . . . 6.840 Nitrogen . . . . . . 0.930

Ferric oxide . . . . . 0.027 Soluble silica . . . . 0.018

Calcium oxide ... . 0.548 Insoluble silica . . . 4.333

Magnesium oxide . . 0.267

37. Sea-Weed. (Two samples.)

Moisture at $100^{\circ}$ C. . . . . . . . . $12.05 \quad 14.96$

Nitrogen . . . . . . . . . . . . . . . . . . . $1.66 \quad 1.28$

Phosphoric acid . . . . . . . . . . $0.44 \quad 0.17$ 
Analyses, continued.

Potassium oxide . . . . . . . . . . . . . $3.81 \quad 0.36$

Calcium oxide . . . . . . . . . . . . $2.73 \quad 3.86$

Magnesium oxide . . . . . . . . . . . . $1.48 \quad 1.30$

Sodium oxide. . . . . . . . . . 11.75 8.40

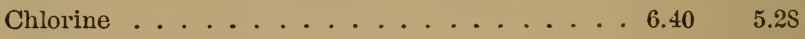

Insoluble matter . . . . . . . . . . 7.73 . 0.78

38. Tobacco-Stems.

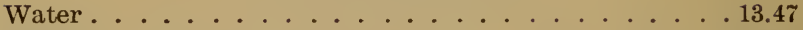

Organic and volatile matters (containing nitrogen 1.93 ) . . 70.85

Ash (containing phosphoric acid, .53) . . . . . . 15.68

100.00

39. Dissolved Bone-Black.

This material is a superphosphate prepared by treating refuse bone-black from sugar-refineries with oi of vitriol, which renders nearly all the phosphoric acid soluble in water.

Soluble phosphoric acid . . . . . . . . . . 14.55

Reverted phosphoric acid . . . . . . . . . . 2.39

Insoluble phosphoric acid . . . . . . . . . . 0.20

40. Bone-Black.

Moisture at $100^{\circ}$ C. . . 5.04 Phosphoric acid . . . . 16.56 Ash . . . . . . . 67 67.43 Insoluble matter . . . 0.3

41. Bone Charcoal.

Moisture at $100^{\circ}$ C. . . 18.16 Reverted phosphoric acid 5.18 Ash . . . . . . . . . 2.24 Insoluble phosphoric acid 20.02 Total phosphoric acid . . 25.58 Insoluble matter . . . 0.69 Solubie phosphoric acid . 0.38

42. Ground Bones. (Two samples.)

Moisture at $100^{\circ}$ C. . . . . . . . . . . . 3.97

II.

Ash ................. . . 49.35

12.43

Total phosphoric acid . . . . . . . . . . . 19.49

64.21

Reverted phosphoric acid . . . . . . . . 3.80

25.67

Insoluble phosphoric acid . . . . . . . . . . . 15.69

6.20

Nitrogen . . . . . . . . . . . . . 4.04

19.34

Insoluble matter . . . . . . . . . . . . . 0.78

2.68

0.42 
Analyses, continued.

\section{Dried Blood.}

Moisture

15.02 Nitrogen

44. Dry Ground Fish.

Moisture at $100^{\circ}$ C. . . . . . . . . . . 8.34

Ash . . . . . . . . . . . . . . . . . . . . . 6

Total phosphoric acid . . . . . . . . . . . 8.23

Soluble phosphoric acid ............. . 0.10

Reverted phosphoric acid . . . . . . . . . 3.81

Insoluble phosphoric acid . . . . . . . . . . 4.32

Nitrogen . . . . . . . . . . . . . . . 6.81

Insoluble matter . . . . . . . . . . . . . . 0.82

45. Sulphate of Ammonia.

This article, now manufactured on a large scale as a by-product of gas-ivorks, usually contains over 20 per cent. of nitrogen, the equivalent of from 94 to 97 per cent. of sulphate of ammonia. The rest is chiefly moisture.

Nitrogen . . . . . . 20.02 Equivalent ammonia . .24.30

46. Sulphate of Potash. (Two samples.)

The double sulphate of potash and magnesia is usually sold as "sulphate of potash."

Actual potash ............ . . 27.76 51.28

Equivalent sulphate of potash . . . . . . 51.3 94.80

47. Sulphate of Magnesia.

Moisture at $100^{\circ}$ C. . . . 29.01 Sulphuric acid . . . 30.35

Magnesium oxide . . . 15.87 Insoluble matter . . . 6.29

\section{Nitrate of Soda.}

Nitrate of soda is mined in Chile and purified there before shipment. It usually contains about 16 per cent. of nitrogen, equivalent to 97 per cent. of pure nitrate of soda. It contains besides, a little salt and some moisture.

Moisture ....... . . 35

Salt (sodium chloride) . . .23
Sulphate of soda $\ldots . .0 .21$

Pure nitrate of soda . . 99.21 
Analyses, continued.

49. Muriate of Putash. (Two samples.)

Commercial muriate of potash consists of about 80 per cent. of muriate of potash (potassium chloride); 15 per cent. or more of common salt (sodium chloride), and $t$ per cent. or more of water.

Actual potash . . . . . . . . . . . . . 50.0 5:52

Equivalent muriate ........... 79.283 .70

50. German Potash Salts-Average of 11 Analyses.

Moisture at $100^{\circ} \mathrm{C}$. . . 13.14 Magnesium oxide . . . 9.25

Potassium oxide . . . 21.63 Sulphuric acid . . . 10.85

Sodium oxide . . . . 13.76 Chlorine . . . . . 35.63

Calcium oxide . . . . 0.85 Insoluble matter . . . 2.0s

51. Kainit-Average of 3 Analyses.

Moisture at $100^{\circ}$ C. . . . 9.26 Magnesium oxide . . . 8.97

Potassium oxide . . . 14.04 Sulphuric acid . . . 21.05

Sodium oxide . . . . 21.38 Chlorine . . . . . 32.38

Calcium oxide . . . . . 1.12 Insoluble matter . . . . 0.59

52. Land-Plaster or Gypsum.

Hydrated sulphate of lime ........... . . . . . . . . .

Matters insoluble in acid . . . . . . . . . . 1.28

Moisture ..................... 1.18

Other matters chiefly carbonate of lime . . . . . . 22.66

53. Ashes (Wood), Unleached.

Moisture at $100^{\circ}$ C. . . . . . . . . . 15.72

Calcium oxide . . . . . . . . . . . . 28.61

Magnesium oxide . . . . . . . . . . . . . 3.00

Ferric oxide . . . . . . . . . . . . 1.03

Potassium oxide . . . . . . . . . . . 8. . . . . . .

Phosphoric acid . . . . . . . . . . . . . 0.32

Insoluble matter, before calcination . . . . . . . 18.49

"، after " ......... . . 12.12

54. Ashes (Wood), Leached.

Moisture at $100^{\circ}$ C. . . . . . . . . . . 13.72

Calcium oxide .................. 48.07 
Analyses, continued.

Magnesium oxide . . . . . . . . . . 6.06

Ferric oxide . . . . . . . . . . . . . . . 0.68

Potassium oxide . . . . . . . . . . . . 1.92

Phosphoric acid . . . . . . . . . . . . 1.79

Insoluble matter, before calcination . . . . . . . . . 5.49

after " $\quad \ldots \ldots \ldots . \ldots 2.57$

55. Coal-Ashes, Bituminous.

Water ....... 5.0 Soda . . . . . 0.4 Organic substance . . . 5.0 Magnesia . . . . . 3.2

Ash ....... . . 95.0 Phosphoric acid . . . 0.2 Potash . . . . . . 0.4 Sulphuric acid . . . . 8.5

56. Coal-Ashes, Anthracite.

Water ....... 5.0 Soda . . . . . 0.1

Organic substance . . 5.0 Magnesia . . . . 3.0

Ash ....... . . 90.0 Phosphoric acid . . . 0.1

Potash . . . . . . 0.1 Sulphuric acid . . . . 5.0

57. Gas-Lime-Average of 4 Analyses.

IMoisture at $100^{\circ}$ C . . 22.28 Sulphuric acid* . . . 20.73

Calcium oxide . . . 4 42.66 Insoluble matter . . 6.05

Magnesium oxide . . . 8.30

* Sulphuric acid includes all forms of sulphur present.

(e.) Trade Valdes for 1891 of Fertilizing Ingredients in Raw Materials axd Chemicals. Adopted by Experiment Stations of Mass., New Jersey, Penn. and Conn.

Nitrogen in ammoniates . . . . . . . . . . 181/2

" nitrates ............... 141/2

Organic nitrogen in dry and fine ground fish, meat and blood.151/2

" " cotton-seed meal and castor-pomace . . 15

" " $\quad$ fine bone and tankage ...... . 15

" " " fine medium bone and tankage... . . 12

" " " medium bone and tankage ..... . . 91/2

" " coarser bone and tankage ..... $71 / 2$

" " hair, horn-shavings and coarse fish-scrap 7 
Analyses, continued.

Phosphoric acid, soluble in water . . . . . . . . . 8

66

64

n

66

6406 ammonium citrate . . . . $7 \frac{1}{2}$

dry ground fish, fine bone and tankage ........ . 7

fine-medium bone and tankage . $5 \frac{1}{2}$ medium bone and tankage . . 4 4/2 coarser bone and takkage . . . 3

Potash as high-grade sulphate and in forms free from muriate (or chlorides) . . . . . . . . . 5 . . . . . . $51 / 2$

“ muriate ................ $41 / 2$

" $A$ man might almost as well draw a check on a bank in which be bas made no deposit, as to plant seed and fruit in poor graund."

-E. P. ROE. 


\section{CHAPTER XXI.}

Names, Histories and Statistics.

1. Vegetables which have different Names in England and America.

In America.

In England.

Artichoke (Helianthus tuberosus) . . Jerusalem artichoke.

Bean ..................... Kidney - bean, or French bean.

Beet ........... Beet-root.

Lima bean ......... . . Lima kidney-bean.

Muskmelon .......... Melon.

Parsnip . . . . . . . . . Parsnep, in many old books.

Pepper . . . . . . . Capsicum.

Pumpkin ........ . . Vegetable marrow. Gourd.

Rutabaga ......... Turnip-rooted c a b b a g e,

Salsify .......... . Salsafy.

Swedish turnip.

Squash . . . . . . . . Pumpkin. Gourd.

"Scallop ........ . Custard-marrow.

"Winter Crookneck . . . . Muskmelon, rarely.

Swiss chard . . . . . . . . . Leaf-beet.

Turnip . . . . . . . . Turnep in many old books. 


\section{Names of Fruits and Vege}

English.

Almond . French.

German.

Apple . Amandier . French.

Apricot

Pommier

Mandel .

Artichoke

Abricotier

Apfel

Asparagus

Artichaut

Aprikose

Banana

Asperge

Artischöke

Bean, Broad . . . Fève de Marais

Spargel

Bean, Kidney . . . Haricot .

Pisang .........

Beet

Betterave.

$\left\{\begin{array}{c}\text { Grosse Bohne and Gar- } \\ \text { ten Bohne ...... }\end{array}\right\}$

Berberry .... Épine vinette.

Türcksche Bohne

Black Currant ... .

Borecole

Broccoli .

Cassis and Groseille noir

Brussels Sprouts

Chou vert, or Non pommé

chwartze Johannisbeere

Cabbage

Broccoli and Chau brocolis . Italienischer Kohl

Cardoon

Chou de Bruxelles or à jets Sprossen Kohl

Carrot Chou pommé or Cabus

Kopfkohl

Cauliflowe

Cardon

Kardon .

Celery

Carotte...

Möhre or Gelbe Rübe

Cherry

Chou-fleur

Blumen Kohl

\section{Chic}

Cress, Garden ... Cresson . . . . . . . . Gemeine Garten Kresse . .

“ Winter. . . Cresson de Terre... . . Winter Kresse

Cucumber .... Concombre . . . . . . Gurke

Egg-plant . . . . Melongène, Aubergine . . Tollapfel and Eierpflanze .

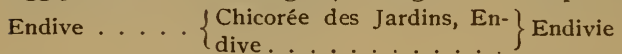

Fig . . . . . Figuier . . . . . . . Feige . .

Filbert . . . Noisette . . . . . Nussbaum

Garlic ... . A Ail . . . . . . . . Knoblauch

Gooseberry . . . Groseiller à Maquereau . Stachelbeere

Grape . . . . . . Vigne . . . . . . . . Traube and Weintrauben

Horse-adish . . Cranson or le Grand Raifort Meerrettig . . . . . . . .

Kohl-rabi or Tur- $\}$ nip-cabbage...

Leek . . . . . Poireau

$\left\{\begin{array}{c}\text { Gemeiner Lauch or Porro } \\ \text { Zwiebe }\end{array}\right\}$

Lemon

Limonier

. Limonie

Lettuce . . . . . Laitue

Gartensalat and Lattich

Melon, Musk

Melon

. Melone 
tables in Various Languages.

Dutch.

Italian.

Spanish.

Amandelboom ... Mandorlo ... . . . Almendro.

Appelboom .... Melo or Pomo . . Manzana.

Abrikozenboom . . . Albicocco . . . . . Albaricoqre.

Artisjok . . . . . . Caciofo . . . . . . Cinauco.

Aspergie . . . . . Asparago or Sparagio . Esparrago.

Bananenboom.

Boon ...... Fava ..... . . Haba.

Turksche Boon . . . Faginolo ... . . Judias and Fasoles.

Beetwortel or Karoot . Barba bietola . . . Betarraga.

Barbarisse ..... Berbero ...... Berberis.

Aalbessenboom . . . . Ribes nero . . . . . Grosella negro.

Gröne Kool . . . . . . Cavolo aperto . . . . Col.

Scotsche Kool . . . . . Broccoli . . . . . . Broculi.

Spruit Kool.

Kool . . . . . . Cavolo ... . . Berza.

Spaansche Artisjok . . Cardon . . . . . . Cardo.

Gerle Wortel .. . . Carota . . . . . . Chirivia.

Bloem Kool . . . . Cavoli fiori . . . Berza florida.

Selderij . . . . . Appio . . . . . . Appio hortense.

Keresenboom . . . Ciriegia . . . . Cerezo.

Suikerei ..... Cicoria ..... Achicuria.

Tuinkers ...... Cresciio . . . . . Mastuerzo.

Waterkers ..... Crescione di Sorgenti . Berro.

Winterkers . . . . . Erba di Santa Barbarea $\left\{\begin{array}{c}\text { Hierba de Santa Barb- } \\ \text { bara. }\end{array}\right.$

Komkommer . . . . Citriuolo . . . . . P epino or Cohombro.

Dolappel ...... Melanza .... Berengena.

Andijvie ..... Indivia . . . . Endivia.

Vijgenboom . . . Fico ...... Higuera.

Hazelnotenboom . . Avellano ...... Avellano.

Knoflook . . . . Aglio ...... Ajo.

Kruisbessenboom . . Uva-spina . . . . . Uva-crespas.

Druif . . . . . . . Vigna . . . . . . Vina.

Rammenas .... Ramolaccio . . . Rabano picante.

Look or Prei . . . . Porro . . . . . . . Puerro.

Limoenboom .... Limoen . . . . . Liislon.

Latouw . . . . . . Lattuga . . . . . Lechuga.

Meloen ....... Mellone and Popone . Melon. 
Names of Fruits and Vegetables in

English.

French.

German.

Mint, common . Menthe des jardins . . . Munze . . . . . . . .

Mulberry ... Mûrier ........ Maulbeere

Mushroom . . . Champignon comestible . Essbare Blätterschwamme

Mustard . . . . Moutarde . . . . . . Senf .........

Nectarine . . Pêche lisse ...... Nectarpfirsch ......

Olive ... . Olivier ....... Oelbaum and Olive .....

Onion ...... Oignon ... . . . Zwiebel .........

Orange ..... Oranger ....... Pomeranze ......

Orach . . . . . Arroche . . . . . . Meldekraut

Parsley ... . Persil ....... Petersilie

Parsnip . . . . Panais .... . Pastinake

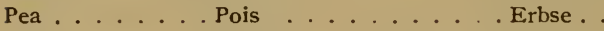

Peach ..... Pêcher ........ Pfirsiche

Pear . . . . . Poirier . . . . . Birne... .

Pepper . . . . Piment ...... Spanischer Pfeffer

Pine-apple ... Ananas ....... Ananas

Plum ... . . Prunier . . . . . . . Pflaume

Pomegranate . . Grenadier . . . . . . Granatenbaum

Potato ... . . Pomme de Terre ... Kartoffel

Pumpkin or Gourd Courge . . . . . . . Kürbis

Quince ..... Coignassier .... . Quitte

Radish . . . . Radis and Rave. . . . Rettig and Radies

Rape ..... Navette ....... Repskohl .

Red Currant . . Groseiller commun . . Gemeine Johannisbeere . .

Rhubarb ... Rhubarbe ...... Rhabarber

Sage ..... Sauge ....... Salbey

Salsify ... . Salsifis .... . . Haferwurzel and Bocksbart

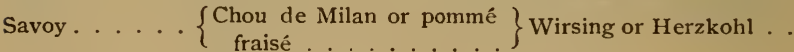

Sea-kale ... Chou marin and Crambé . Meerkohl .

Spinach . . . . Épinard ..... . Spinat

Strawberry . . . Fraisier . . . . . . . Erdbeer

Sweet Chestnut . . Châtaignier and Marronier Castanien

Thyme ... . Thym ..... . Thimian

Tomato.... Tomate....... Liebesapfel

Turnip ..... Navet . . . . . . . Rübe

Walnut .... Noyer ........ Wallnuss

White Currant . . uroseiller commun . . . Gemeine Johannisbeere .

Watermelon ... Melon d'Eau ...... Wassermelone ..... 
Varions Languages, continued.

Dutch.

Italian.

Spanish.

Munt . . . . . Erba Sta. Maria . . Menta.

Moerbezieboom . . . Moro . . . . . . Moral.

Kampernoelio . . . . Pratajuolo bianco . . . Seta.

Mosterd .. . . . . Senapa . . . . Mostaza.

Kale Perzik . . . . . Brugnuolo . . . . Especie de Durazno.

Olijfboom . . . . . Ulivo . . . . . Olivo.

Uijen ... . . . Cipolla . . . . Cebolla.

Oranjeboom .... Arancio . . . . Naranja.

Melde. . . . . . Atreplice . . . . . Armuelle.

Piêterselie ... . . Petroseline . . . . Perejil.

Pinksternakel . . . . Pastinaca . . . . . Chirivia and Pastinaca.

Erwt . . . . . . Pisello . . . . . Guisante.

Perzikboom ..... Persico ...... Alberchigo

Perenboom ... . Pero . . . . . . Pera

Spaansche Peper . . Peberone. . . . . . Pimiento.

Ananas ....... Ananas ... . . Pina

Pruinboom . . . . . Prungo . . . . . Ciruelo.

Granaatboom . . . Melagrano ... . Granada.

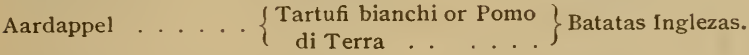

Kauwörde . . . Zucca ... . . Calabaza.

Kweeboom . . . . Cotogno . . . . Membrillo.

Radijs ... . . . Rafano ... . . Rabano.

Rapskool . . . . . Nape salvatico . . . . Naba silvestre.

Aalbessenboom ... Ribes rosso . . . . . Grosella.

Rabarber . . . . . Rabarbaro . . . . Ruibarbo.

Salie ..... Salvia ..... . Salvia.

Boksbaard ... . Sassifica .... Barba Cabruna.

Savojie Kool . . . . Cappuccio . . . . Berza de Saboyá.

Zeekool . . . . . . Crambe marina . . . Col marina.

Spinazie ... . . Spinace . . . . Espinaca.

Aardbeziënplant .. . Piantadifragola . . . Fresa.

Kastanjeboom ... Castagno . . . . Castano.

Gemeene Thyne . . Timo . . . . . . Tomillo.

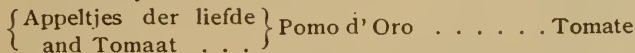

Raap . . . . . . . Navone . . . . . . Nabo.

Walnotenboom ... Noce . . . . . Noguera.

Aalbessenboom . . . Ribes rosso . . . . Grosella.

Sandia. 


\section{Derivation of the Names of Various Fruits and}

\section{Vegetables.}

a. Fruits.

Apple.-Anglo-Saxon, ceppel.

Apricot.-Indirectly from Latin pracox, early.

Blackberry.-From the color of the fruit.

Cherry.-Anglo-Saxon, cirse.

Cranberry.-Crane-berry, from the slender pedicel of the European species.

Currant.-Corruption of Corinth, Greece, whence came tho "dried currants" (grapes), which were once called Corinths.

Gooseberry.-Gorse-berry, because the fruit is often rough like the gorse, an European plant.

Grape.-French, grappe; allied to the word grapple.

Lemon.-French, limon.

Malberry.-German, mulber, indirectly from Latin morus, a wulberry tree.

Nectarine.-Nectar-like.

Orange.-Latin, aurum, gold.

Peach.-Corruption of Persia, whence the fruit was early obtained.

Pear.-Pirum, the Latin name.

Plum.-Anglo-Saxon, pluma; indirectly from Latin prunum, a plum.

Quince.-Corruption of Cydonia, the Lation name, from Cydon. Raspberry.-From rasp, referring to the character of the plant. Strawberry.-In early times the berries were strung on straws when sold.

\section{b. Vegetables.}

Artichoke.-Italian, articiocco; indirectly from the Arabic.

Asparagus.-The Latin name.

Bean.-The Anglo-Saxon name.

Beet.-Latin, beta, the beet-plant.

Cabbage.-French, cabus, from the Latin caput, a head.

Carrot.-French, carotte, from Latin ccrota, the carrot.

Brussels sprouts.-From Brussels, Belgium.

Cauliflower.-Latin, caulis, stem, and flower.

Celery.-Latin, selinon, parsley. 
Derivation of the Names of Fruits and Vegetables, continued.

Chervil.-Anglo-Saxon, cerfille, indirectly from a Greek combination signifying "pleasant-leaf."

Chives or Cives.-Latin, cepa, onion.

Corn.-Anglo-Saxon, corn.

C:'ess.-Old German, kresan, to creep.

Cacumber.-Latin, cucumis.

Egg-plant.-From the egg-shaped fruit of some varieties.

Endive.-French, endive, indirectly from the Latin intubus, the endive or chicory.

Garlic.-Anglo-Saxon, gar and leak, spear-leaf, referring to the shape and position of the leaves.

Gumbo.-Portuguese, quingrmbo, from quillobo, an African name.

Horse-radish.-Refers, evidently, to the strong and pungent character of the roots by reference to the strength of the horse.

Kohlrabi.-Colruption of the Latin caulo-rapa, stem-turnip.

Leek.-Anglo-Saxon, leac or leak.

Lettuce-Latin, lactuca, the lettuce; from lae, milk, referring to the milky juice of the plant.

Melon,-Latin, melo, a certain small melon.

Mushroom.-French, mousseron, alluding to mousse, or moss, in which some mushrooms grow.

Mustard.-French, mustarde, from Latin mustum, the must, with which mustard was mixed.

Onion.-French, oignon; indirectly from Latin unus, one, unis, oneness, ir allusion to a plant of which the oulb was formed of one piece.

Parsley.-From a Greek combination meaning "rock-parsley," a parsley-like plant.

Parsnip._Latin, pastinaca.

Pea.-French, pois, evidently from Latin pisum, the pea.

Pepper, Red.-Latin, piper, the true pepper or black pepper, with which the present plant is compared in pungency.

Potato.-Spanish and Portuguese, batata, probably an aboriginal American name. First applied to the sweet-potato.

Pumpkin.-French, pompion, from Latin pepo, a pumpkin-like fruit.

Radish.-Latin, radix, root. 
Derivation of the Names of Fruits and Vegetables, continued.

Rhubarb.-French, rhubarbe; probably indirectly from Latin. barbarus, foreign.

Sage.-Latin, salvus, saved, evidently in allusion to medicinal properties of the plant.

Salsify.-French, salsifis.

Spinach or Spinage-Latin, spinacia, spinach, from spina, a thorn, in reference to the prickly character of the plant.

Squash.-American Indian, asquash, a raw or green fruit.

Tomato.-Tomate, of South American origin.

Turnip.-Probably Welsh turn, round, and maip, turnip.

\section{Periods of Cultivation and Native Countries of Cultivated Plants.}

(Adapted from researches of De Candolle, and Gray and Trumbull.)

Almond. Over 4,000 years; Mediterıanean basin, western temperate Asia.

Apple. Over 4,000 years; Europe, Anatolia, south of the Caucasus.

Apricot. Over 4,000 years; China.

Artichoke. Less than 2,000 years; Europe, Africa, Canaries and Madeira.

Asparagus. Over 2,000 years; Europe, western temperate Asia. Banana.-Over 4,000 years; southern Asia.

Barley, Common. (?); western temperate Africa.

Bean, Kidney. Over 4,000 years; unknown wild. Probably N. America.

Bean, Broad. Over 4,000 years; south of the Caspian (?).

Buckwheat. Less than 2,000 years; Mandschuria, central Siberia.

Buckwheat, Tartarian. Less than 2,000 years; Tartary, Siberia to Dahuria.

Cabbage. Over 4,000 years; Europe.

Carrot. Over 2,000 years; Europe, western temperate Asia (?). Celery. Over 2,000 years; Europe, Asia and Africa.

Chestnut. (?) ; from Portugal to Caspian Sea, eastern Algeria. Chives. Less than 2,000 year's; temperate and northern Europe. Citron. Over 2,000 years; India.

Corn-salad. Less than 2,000 years; Sardinia, Sicily. Cotton, Herbaceous. Over 2,000 years; India. 
Periods of Cultivation and Native Countries of Plants, continued.

Cress, Ovər 2,000 years; Persia (?).

Cucumber. Over 4,000 years; India.

Currant, Black. Less than 2,000 years; Europe, western Hima layas.

Currant, Red, Less than 2,000 years; Europe to Himalayas.

Date-palm. Over 4,000 years; western Asia and Africa.

Egg-plant. Over 4,000 years; India.

Endive. Less than 2,000 years; Mediterranean basin.

Fig. Over 4,000 years; south of Mediterranean basin.

Garlic. Over 2,000 years; desert of the Kirghis.

Gooseberry. Less than 2,000 year's; temperate Europe, western Himalayas.

Hop. Less than 2,000 years; Euroje, Asia, U. S.

Horse-radish. Less than 2,000 years; eastern temperate Europe.

Jerusalem Artichoke. Probably ancient; U. S.

Leek. Over 2,000 years; Mediterranean basin.

Lettuce. Over 2,000 years; Europe, Asia and Africa.

Maize. Very ancient; New Granada (?).

Melon. Less than 2,000 years; India, Beluchistan, Guinea.

Mushroom. Less than 2,000 years; Northern hemisphere.

0ats. Over 2,000 years; temperate Europe.

0kra. Less than 2,000 years; tropical Africa.

Onion. Over 4,000 years; Persia, Afghanistan, Beluchistan, Palestine(?).

Onion, Welsh. Less than 2,000 years; Siberia.

Orach. Less than 2,000 years; northern Europe and Siberia.

Parsley. Less than 2,000 years; Europe, Algeria and Lebanon.

Parsnip. Less than 2,000 years; central and southern Europe.

Pea. Over 2,000 years; Caucasus to Persia(?), India(?).

Peach. Over 4,000 years; China.

Pear. Over 4,000 years; temperate Europe and Asia.

Pepper. Over 500 years; Brazil(?).

Pineapple. Over 500 years; Mexico, Central America.

Plum. Over 2,000 years; Anatolia, north of Persia.

Potato, Orer 500 years; Chili, Peru.

Pumpkin and Squash. Orer 500 years; temperate N. America.

Quince. Over 4,000 years; north of Persia, south of the Caucasus, Anatolia. 
Periods of Cultivation and Native Countries of Plants, continued. Radish. Over 2,000 years; temperate Asia.

Rampion. Less than 2,000 years; temperate and southern Europe.

Rape. Over 4,000 years; Europe, western Siberia (?).

Rice. Over 4,000 years; India, southern China.

Rye. Over 2,000 years; eastern temperate Europe(?), south. east of Europe, Algeria.

Salsify. Less than 2,000 years(?); southeastern Europe, Algeria. Sea-Kale. Less than 2,000 year's; western temperate Europe.

Scorzonera. Less than 2,000 years; southwestern Europe.

Shaddock. Over 2,000 years; Pacific Islands.

Shallot. Less than 2,000 years; unknown wild.

Spinach. Less than 2,000 yearś ; Persia(?).

Sorghum, Uver 4,000 years; tropical Africa(?).

Strawberry, Chile. Less than 300 years; Chile.

Strawberry, Virginia. Less than 300 years; temperate $\mathrm{N}$. America.

Sunflower. Very ancient; U.S.

Sweet-Potato. Very ancient; tropical America.

Tomato. Over 500 years; Peru.

Turnip. Over 4,000 years; Europe, western Siberia(?).

Watermelon. Over 4,000 years; tropical Africa.

Wheat. Over 4,000 years; region of the Euphrates.

\section{Statistics of the Vegetable Kingdom.}

There are 200 natural families or orders of flowering plants, about 7,600 genera; and about 100,000 species are known and described. The flowerless plants are much more numerous than the flowering plants, both in individuals and species. Ferns, mosses, mushrooms and many smaller or even miscroscopic fungi, lichens and sea-weeds are flowerless plants.

The Ranunculaceæ or Crowfoot family includes over 1,200 species of plants, inhabiting all parts of the world. The clematis, marsh-marigold or so-called cowslip, columbine, adonis, buttercup, Christmas rose, love-in-a-mist, larkspur, aconite and peony are members of the Crow foot family. The family comprises 30 genera.

There are about 100 species of clematis known. 
Statistics of the Vegetable Kingdom, cuntinued.

About 40 distinct species of delphinium or larkspur are described, few of which are cultivated, however.

It is thought that there are about a half-dozen true species of peonies known, although many supposed species have been described.

The Magnolia family comprises about 70 species of trees and shrubs. Of these, 14 are magnolias proper, of which 6 or 7 are native of Japan, China or the Himalaya region, and the remainder are North American. The tulip-tree, of which but a single species is known, belongs to this order.

The Nymphracere or Water-lily family contains 8 genera and about 35 species, all aquatic. The largest genus is nymphæaby some called castalia-comprising some 20 species.

The Mustard family, Cruciferæ, comprises probably about 2,000 species, many of which are grown for food and ornament. The cabbage, cauliflower, turnip, kohlrabi, radish, horse-radish, sea-kale, cresses and mustards are the leading edible species, while the stocks, alyssum, wallflower, honesty or lunaria are among the ornamental species. There are over 175 genera in the order.

The Violet family comprises about 250 species, generally distributed over the world. Of these, about 200 are violets. The order includes 21 genera. Some of the species, outside of viola proper, are shrubs or small trees.

The Caryophyllacea or Pink family has about 1,000 species and 35 genera. The ornamental genera are dianthus, including the pinks and carnation, saponaria, silene, lychnis and a few others of less importance. Dianthus, literally "Jove's flower," number's some 200 species. The corn-cockle and catchflies belong to this family.

The Mallow family, Malvacex, has about 60 genera and 700 species. The best-known genera are althæa, the hollyhock; malva, the mallows; hibiscus; abutilon; and gossypium, the cotton.

The Basswoods or Lindens are 8 in number, growing in northern temperate climates. Three are natires of North America. Tiliaceæ, the Basswood family, comprises 40 genera and about 330 species. 
Statistics of the Vegetable Kingdom, continued.

Some 50 species of maples are known, inhabiting Europe, Asia and America. Nine grow naturally in North America. The Silpindaceæ, to which family the maple belongs, is largely tropical. It comprises over $\% 0$ genera, and 600 or $\% 00$ species. Asculus, the horse-chestnuts, belong here, and are about 14 in number.

The Leguminosæ or Pulse family is one of the most important orders of plants. It furnishes many foods, fine woods, dyes, medicines and oruamental plants. Many of the species are extremely important in agriculture because of the great amount of nitrogen they contain. Peas, beins, clover, locusts, acacias, sensitive-plant, belong to this family. It comprises about 400 genera and 6,500 species.

The Rosacere or Rose family may be called the fruit family of the north temperate zone. Apples, pears, quinces, June-berries, strawberries, blackberries, raspberries, peaches, plums, apricots, almonds, cherries, all belong here. Prunus, which includes the stone-fruits, has about 100 species in various parts of the world, and 25 are North American. Pyrus, including, apple, pear, quince and mountain-ash, has about 40 species, of which 9 are in North America. Of roses, over 250 have been described, but late authorities consider that there are only about 30 good species. Of strawberries, there are 3 or 4 species, and of spiræa about 50. The whole family has about 1,000 species and 70 genera.

Vitis, the grape and its allies, has some 230 species. There are two or three other genera, and about a score of other species in the family, vitaceæ or ampelideæ, to which it belongs.

The Cucurbitaceæ includes the squashes, pumpkins, cucumbers, melons and gourds. The species are about 500 in number, and are mostly tropical or subtropical. Some 25 species are described as cucumis, to which the cucumber and muskmelon belong, and 2 as citrullus or watermelon. The pumpkins and squashes belong to cucurbita, of which about 10 species are known, several of them perennials. The family comprises about 70 genera.

About 350 species of begonia are known.

Of cacti, there are about 1,000 species and 13 genera, all but one species native of the New World. 
Statistics of the Vegetable Kingdom, continued.

Umbelliferæ, comprising over 150 genera and about 1,300 species, includes the parsnip, par'sley, carrot, celery, caraway, anise, dill and others. In Africa some of the species attain to the size of trees.

About one-ninth of all flowering plants are comprised in the Compositæ or Sunflower family. It is by far the largest order, containing nearly 800 gencra and about 10,000 species. Very few of the species furnish esculent parts; the leading ones are lettuce, endive, chicory, artichoke, cardoon and salsify. But the family comprises great numbers of ornamental plants, of which the leading one at the present time is the chrysanthemum. A very few of the species become small shrubs.

The Heath family, Ericacex, includes the heaths, heather of Europe, wintergreen, whortleberries or huckleberries, cranberries, azaleas, rhododendrons and laurels. Certain white and flesh-colored parasitic plants also belong to it, as the Indian-pipe and the snow plant of the Rocky Mountains. About 80 genera and over 1,300 species are known.

The Primulas belong to the Primulacea or Primrose family, and they number some 80 or more species, many of which are cultivated. The genus primula is commonly divided by florists into auriculas, polyanthuses and primroses. One of the primulas is the true cowslip. Primulacere has about 20 genera and 250 species.

Oleaceæ, a family of 18 genera and nearly 300 species, includes the jasmine, forsythias, lilacs, ashes, privet and olive. 12 species of fraxinus or ash, are native to North America. There are about 120 species of jasminum or jasmine, 2 of forsythia, 6 of syringa or lilac, over 30 of fraxinus, about 25 of ligustrum or privet, and 35 of olea, or olive.

The Convolvulus or Morning-glory family, Convolvulacex, has some 800 species, some of which are trees, and 32 gencra. The dodders, peculiar parasitic plants, of which several are natives of the United States, belong here, as does also the sweet-potato.

There are about 30 species of Phlox described, nearly all natives of North America. The common Phlox Drummondii is a native of Texas.

Solanaceæ is a large and important order, containing many 
Statistics of the Vegetable Kingdom, continued.

esculent plants and many poisons. Here belong the potato, tomato, egg-plant, red pepper, and strawberry or husk-tomato; also tobacco, belladonna and nightshade. There are 66 genera and from 1,200 to 1,500 species. The genus solanum alone, to which the potato and egg-plant belong, contains from 700 to 900 species. Lycopersicum, the tomato genus, has less than a half dozen species.

There are about 140 genera and 2,600 species in the Labiatæ or Mint family. The order comprises a few tree-like and a few climbing plants. The species are aromatic, and most of our cultivated sweet herbs, and all the mints, belong to the family. It comprises many ornamental species, among the most prominent being species of coleus, of which about 50 species are described.

The Nettle family or Urticaceæ comprises many dissimilar plants. Here belong the nettles, mulberry, fig, bread-fruit, hackberry, osage-orange, elm, hemp, and hop. The family has in the neighborhood of 1,500 species, and the accepted genera are 108. Five elms and 2 mulberries are native to North America, and 3 wild figs grow in southern Florida.

Five genera and about 30 species belong to the Juglandaceæ or Walnut family. All the hickories, 8 or 10, are natives of North America. There are 2 walnuts and 1 butternut in the United States.

Cupuliferæ, the Oak family, numbers 400 species and 10 genera. It gives us the oaks, about 300 in the world and 44 in the United States; chestnuts, beeches, hazels and filberts, birches, alder, hornbeam, and ironwood. The United States has 2 chestnuts, 1 beech, about 8 birches and 6 alders.

The Pine or Spruce family is known as the Coniferæ, or conebearing family. It includes plants of very dissimilar kinds. Most of the species have needle-like and evergreen leaves, but some are deciduous, and the gingko has broad and flat leaves. There are more than 30 genera and about 300 species in the family. Of pines there are about $\% 0$, and 35 of them are native to the United States.

Orchidaceæ, the Orchid family, includes some 5,000 singular herbs, distributed through 334 genera. Many of the species are 
Statistics of the Vegetable Kingdom, continued.

epiphytes, that is, growing above ground on other plants. The species are the most specialized, perhaps, of any order, and they are usually uncommon or rare. A number of showy species grow in the United States, the best-known of which are the lady-slippers. Our species usually inhabit bogs or deep woods.

Over 2,000 species, in $18 \pi$ genera, comprise Liliaceæ, or the Lily family. Some of the species are tree-like. Here belong the onion, asparagus, tulip, aloes, yuccas, hellebore, and many choice ornamental plants. Of lilies, there are about 45 species, tulips in the neighborhood of 50 , and of hyacinths about 30 .

The Palm family, Palmæ, includes 1,100 or more species and 132 genera. Many species produce edible fruits, the best-known in our markets being the date and the cocoanut.

The Gramineæ or Grass family is the most important order of plants. Besides all the grasses, it furnishes all the cereal grains, including Indian corn and the sugar-cane. Genera about 300 ; species more than 3,000 .

There are about 74 genera of ferns or Fiiices, and in the neighborhood of 2,400 species. Some of the species attain to the size of small trees. 


\section{CHAPTER XXII.}

\section{Glossary.}

Acclimation. The spontaneous or natural process of becoming, or the state or condition of being, inured or habituated to a climate at first injurious:

Acclimatization. The act of man in inuring or habituating to a climate at first injurious, or the state or condition of being thus inured or habituated by man.

Adventive. Said of foreign plants which grow spontaneously, but which are not thoroughly established.

Agriculture. The art and science of cultivating land and raising crops and stock. The term is often restricted to include only the cultivation of grains and forage-plants and the rearing of domestic animals, with the operations and studies incident thereto.

Albornum. Sap-wood.

Ammonia. A pungent gas, composed of one atom of nitrogen to three of hydrogen.

Annual ( $A d j$.) Living for one year only.

Arm. In grape-culture, a vine-branch more than a year old.

Assimilation. In botany, the production of organic mattcr from inorganic matter.

Bacterinm (pl. bacteria). As popularly used, the term is applied to an extensive class of microscopic organisms, usually classed with plants. The term microbe is used in the same sense.

Basin. In descriptions of apples and related fruits, the depression at the apex of the fruit. The ealyx sits in the basin. 
Berry. In botany, and properly, a separate fruit which is pulpy and juicy throughout, as the grape, currant, tomato. The word is commonly employed to denote any soft fruit or fruit-like part which is borne upon a woody or perennial plant. The raspberry and blackberry are collections of little fruits.

Biennial $(A d j$.$) . Persisting two years. As a rule, biennial plants$ do not blossom until the second year.

Bigeneric half-breed. The product of a cross between varieties of species belonging to different genera.

Bigenric hybrid. A hybrid between species of different genera; bigener.

Blight. The dying without apparent cause of the tenderer parts of plants, especially of the leaves, flowers and young fruit; as pear-blight.

Botany. The science of plants.

Bottle-grafting. A modification of whip-grafting by which a heel of the scion is conducted into a bottle of water to supply temporary nourishment.

Bottom neat. Heat applied underneath plants by artificial means.

Bract. A much reduced leaf. Bracts are usually present about the inflorescence.

Break. A radical departure from the type. Ordinarily used in the sense of sport, but in its larger meaning it refers to the permanent appearence of apparently new or very pronounced characters in a species.

Bud. A bud which is inserted in a plant with the intention that it shall grow.

Budding. The operation and practice of inserting a bud in a plant with the intention that it shall grow.

Bulb. A large, more or less permanent leaf-bud, usually occupying the base of the stem, and emitting roots from its lower portion. Bulbs are of two leading sorts; scaly, when composed of narrow and mostly loose scales, as in the lily; laminated or tunicated, when composed of more continuous and closer-fitting layers, as in the onion.

Bulbel. A small bulb borne about a mother-bulb, as in some bulbous irises and some onions; bulbule.

Bulblet. A small bulb borne entirely above ground, as in the axils of leaves, in the inflorescence, etc.

Bulbo-tuber. A corm. 
Bulbule. A bulbel.

Bush. A small woody plant having no central trunk or stem; shrub.

Bush-frait. Small fruits, as the currant, gooseberry, raspberry, and the like.

Callus. The new and protruding tissue which forms over a wound, as over the end of a cutting.

Calyz. The outer envelope of the flower. The parts, when distinct, are called sepals. In apples, pears, etc., part of the calyx persists on top of the fruit.

Cambium. The layer of new tissue which lies underneath the bark. It is usually thin and more or less mucilaginous in spring and early summer.

Cane. A young growth of hard-wooded plants. Usually applied to ripened or hardened shoots a year or less old.

Cantaloape. A class of muskmelons characterized by firm and warty or scabby rinds.

Capsule. A dry seed-ressel which splits open at maturity ; pod.

Carbon dioxide. A gas composed of one atom of carbon to two of oxygen. It is heavier than air, and is poisonous in large quantities; carbonic acid gas.

Carbonic acid. Carbon dioxide.

Carpel. A simple pistil, or one of the divisions of a compound pistil.

Cavity. In descriptions of apples and similar fruits, the depression about the stalk or stem.

Chlorophyl. The green coloring-matter of plants.

Cion. See Scion.

Cleft-graft. A sort of grafting in which the scion is cut wedgeshaped at the lower extremity, and is then inserted in a cleft in the end of a trunk or branch which has been severed.

Close fertilization. The action of pollen upon the pistil of the same flower; self-fertilization.

Coldframe. A frame covered with glass, cloth or paper, without bottom heat, used for starting plants early in spring, for receiving plants transplanted from a hotbed or forcing-house. or for protecting plants during the winter.

Conservatory. A glass house for preserving or growing tender plants. Popularly, the term is applied to houses in which plants are grown for display of flowers. 
Corolla. The inner envelope of the flower. The parts, when distinct, are called petals.

Corm. A solid bulb-like tuber, as in the gladiolus and crocus; bulbo-tuber.

Corymb. A flower-cluster which is flat or convex on top and in which the outer flower blooms first.

Cotyledon. A small leaf borne in the seed; seed-leaf. In many plants the cotyledons rise to the surface when the seed germinates, and increase in size.

Cross. The offspring of any two flowers which have been crossfertilized.

Cross-breed. A cross between varieties of the same species; half-breed, mongrel, variety-hybrid.

Cross-fertilization. The action of pollen upon the pistil of another flower of the same species. Cross-fertilization is commonly used to denote the mere conveyance of pollen-pollination-but better usage confines the term to the action of pollen upon the pistil.

Cross-pollination. The conveyance of the pollen to the stigma of another flower.

Crossing. The operation or practice of cross-pollination.

Crown-grafting. Grafting at or near the surface of the ground.

Cryptogam. One of the class of flowerless plants. These plants propagate by spores instead of seeds. Ferns, fungi, mosses and sea-weeds are examples.

Cutting. A portion of a plant which is inserted in soil or water with the intention that it shall grow; slip.

Cyme. A flower-cluster, flat or convex on top, and in which the central flowers open first.

Deciduous. Said of plants whose leaves fall in autumn.

Derivation hybrid. A hybrid between hybrids, or between a hybrid and one of its parents; derivative hybrid; secondary hybrid.

Dibber. See dibble.

Dibble. A pointed instrument used for making holes in the ground for the planting of seeds and roots; dibber.

Diœcious. Said of species in which the stamens and pistils are borne on different plants.

Disbodding. The practice or operation of remoring buds. 
Double-graft. A plant twice grafted for the purpose of overcoming the lack of affinity between stock and scion.

Double-grafting. The practice and process of twice grafting or budding a plant so that the root, the stem or a part of it, and the top, shall each represent a different variety. It is used when a certain variety will not grow upon a given root, but which will grow on some variety that unites with that root; double-working.

Double-working. See Double-grafting.

Drupe. A fleshy or soft fruit formed entirely from the ovary, and containing a hard pit; stone-fruit. The peach and cherry are examples.

Embryo. The rudimentary plant contained in the seed; scedgerm.

Entomology. The science of insects.

Evergreen. Said of plants which hold their leaves during winter.

Eye, A cutting composed of a single bud.

Family. A group of genera and species, as Cruciferce, mustard family; Gramince, grass family. In botany, order is the same.

Fecundation. The action of the pollen upon the pistil ; fertilization; impregnation.

Female. Used to designate flowers or plants which bear only styles.

Fertilization. The action of the pollen upon the pistil; fecundation; impregnation. :

Fertilizer. 1. Any substance which promotes plant-growth. 2. Plant-food.

Fertilizing. The act or process of applying fertilizers to plants. The word fertilization should be restricted to designate the action of pollen.

Flagging. Wilting of newly-set plants or herbaceous cuttings.

Flat. A shallow box used by gardeners in which to sow seeds or handle plants.

Floricalture. The cultivation of flowers.

Florist. One who practices floriculture.

Flower. An organ which contains a stamen or pistif, or both. It is usually provided with some kind of an envelope, as calyx and corolla.

Forcing-honse. A structure in which plants are grown or forced out of their season. 
Frame. The structure forming the sides and ends of coldframes or hotbeds. A frame is usually understood to be the area covered by a single sash, when areas are to be designated.

Fruit. 1. Botanically, a ripened ovary containing the seeds. 2. Popularly, any edible or ornamental organ or collection of organs which are closely associated in their origin with the flower.

Fungicide. A substance employed to destroy fungi.

Fungoid $(a d j$.$) . Fungus-like in general appearance or character-$ istics. A fungoid disease is one which appears to be due to a fungus, but whose character is not understood.

Fungous (adj.). Pertaining or due to a fungus or to fungi ; as, a fungous disease.

Fungus (pl., fungi). A flowerless plant, devoid of chlorophyl, drawing its nourishment from living plants or animals, or from decaying matter.

Gardener. One who practices horticulture on a small or on an intensive seale.

Gardening. The art and science of raising kitchen-garden vegetables, fruits and ornamental plants; horticulture. The term is commonly restricted, however, to the operations of growing kitchen-garden vegetables and flowers.

Genus (pl., genera). A group or kind containing a greater or less number of closely related species; as $R \omega s a$, the rose genus, Tilia, the linden genus.

Germination. The act or process by which a seed or spore gives rise to a new andeindependent plant.

Gourd. An ambiguous term, used in America to designate various small fruits of the pumpkin and squash genus which are grown for ornament and curiosity. In other countries the term is generic for most pumpkins and squashes.

Graft. Scion, which see.

Graftage. The process of grafting, or the condition or state of being grafted.

Grafting. The operation of inserting a bud or seion upon a stock. It is commonly restricted to the operation of inserting scions of dormant wood, or to those operations in which wax or mastic is used to dress the wounds.

Greenhouse. A glass house in which plants are grown. Originally and properly, however, it was applied to houses in which plants were simply preserved green during the winter. 
Ha-ha. A sunken fence.

Half-Breed. A cross between varicties of the same species; cross-breed, mongrel, variety-hybrid.

Half-Hardy $(a d j$.$) . A term applied to plants which need protec-$ tion during winter, but which can endure some frost.

Half-hybrid. The product of a cross between a species and a variety of another species.

Hand-box. A box of size sufficient to cover a hill of plants, provided with a cover of glass, cloth or paper, used to force plants in the hill.

Hardiness. Capability to endure a given climate.

Hardy (adj.). Able to withstand a given climate.

Heart-wood. The inner and colored wood of trees. The deeper color and greater hardness of heart-wood are due chicfly to the deposition of mineral matter in the cells.

Herb. A plant possessing but a small amount of hard, woody fiber, the stem of which dies at the approach of winter.

Herbarium. A collection of preserved plants. The plants are usually dried and glued on sheets of paper.

Heeling-in. The process and operation of temporarily covering the roots of plants to preserve them until wanted for permanent planting.

Horticulture. The art and science of raising fruits, kitchen-garden vegetables, flowers, and ornamental trees and shrubs.

Horticultarist. One who practices horticulture.

Hotbed. A frame covered with glass, cloth or paper, provided with bottom heat, and used for forcing planes.

Hothouse. A glass house, artificially warmed, in which plants are grown.

$\mathbf{H y}^{\prime}$ brid or hyb'rid. The offspring of plants of different species.

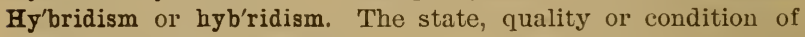
being a hybrid; hybridity.

Hy'bridist. One who practices hybridizing.

Hy'bridity or hyb'ridity. Hybridism.

Hy'bridization or hyb'ridization. The state or condition of being hybridized; or the process or act of hybridizing.

Hybridization. The action of the pollen of one species upon the pistil of another species.

Hy'bridizing or hyb'ridizing. The operation or practice of crossing species. 
Impregnation. The aetion of the pollen upon the pistíl; fertilization; fecundation.

Inarching. The process of grafting contiguous plants or branches while the parts are both attached to their own roots. When the parts unite, one is severed from its own support.

Individual fertilization. Fertilization between flowers upon the same plant.

Inorganic. Pertaining to unorganized substances, as minerals, rocks, chemicals, etc.

Insect. An artieulate animal which in the mature state has three distinct divisions and six legs.

Insecticide. A substance employed to destroy inseets.

Kitchen-garden. An area deroted to the eultivation of "vegetables," or annual plants which yield edible parts.

Kitchen-garden vegetable. An edible portion of an annual plant. A loose term, commonly shortened to vegetable.

Landscape-gardening. The art of embellishing grounds. It demands a high appreciation of natural scenery and an ability to represent it in grounds.

Landscape-horticultare. The operations and manual appliances employed in embellishing grounds; the industrial phase of landscape-gardening.

Larva (pl., larvos). The worm-like stage of insects. A larva is commonly called a worm.

Lawn. An area of greensward used for ornamental purposes.

Layer. A shoot of a plant bent down and partly or wholly covered with earth with the intention that it shall take root, when it ean be severed from and become independent of the parent plant.

Layerage. The state or condition of being layered, or the operation or practice of layering plants.

Legume. A simple pod composed of two valves or parts, as pea and bean pods.

Leguminous. Of or pertaining to legumes. Used to designate plants of the pea and bean fumily.

Maiden (adj.). Applied to young plants which have not borne.

Male. Used to designate flowers or plants whieh bear only stamens.

Manure. 1. Any substance which promotes plant-growth. 2. Plant-food. 
Microbe. A term applied to various microscopic organisms usually classed with plants, which play an important rôle in disease, chemical decomposition, and decay.

Mildew. A powdery or mold-like growth attached lightly to the surface of the plant, particularly when it is white or nearly so, as gooseberry-mildew.

irongrel. A cross between varieties of the same species; halfbreed; cross-breed; variety-hybrid.

Monœcious. Said of plants in which the stamens and pistils are borne in different flowers on the same plant.

Mother-bulb. The large bulb about which bulbels are formed.

Mycology. The science of fungi.

Nursery. An establishment for the rearing of plants. In America the word is used in connection with woody plants only.

Offscape. The landscape which lies adjacent to one's grounds.

Olericulture. The cultivation of kitchen-garden vegetables; vegetable-gardening.

Open. An unplanted portion of grounds; an open lawn or field.

Order. Family, in botany.

Organic. Pertaining to organized or living bodies or their remains.

0vule. A sexual body borne in the ovary, which, when mature, becomes the seed.

0vary. The lower extremity of the pistil, which, when mature, becomes the fruit. It contains the ovules.

Panicle. An open and more or less compound flower-cluster.

Papilionaceous. Butterfly-like; said of flowers of the pea and bean family, from their fancied resemblance to butterflies.

Parasite. A plant or animal which lives upon living plants or animals.

Pedicel. The stalk of a particular flower in a cluster. A flower which is borne singly has a peduncle.

Peduncle. A stalk of a flower which is borne singly, or of a cluster of flowers.

Pepo. A berry-like fruit in which the rind is hardened, and which belongs to the gourd family, as the pumpkin, melon, cucumber, etc.

Perfect. Said of flowers which bear both stamens and pistils. 
Perianth. The leaves of a flower. Usually applied to those flow_ ers in which the caly $\mathrm{x}$ and corolla are nearly alike, as the lily.

Perennial (adj.). Persisting from year to year. The term perennial is commonly understood to designate herbaceous plants which live for many years.

Pet'al, or Pe'tal. One of the separate parts of the corolla; an inner leaf of a flower.

Petiole. The stem of a leaf.

Phenogam. One of the class of flowering plants. These plants propagate by seed.

Pip. A term applied to certain small seeds or seed-like fruits of berries and other fruits.

Pip'ing. A cutting.

Pistil. That portion of the flower which receives the pollen and bears the seeds. It always has two parts, the stigma and the ovary, and these are usually connected by a style. It is the female organ of the plant.

Pistillate. Bearing pistils alone; female.

Plantlet. The little plant just emerged from the seed. It becomes a plant when it is able to assimilate and lead an independent existence.

Pod. A dry seed-vessel which splits open at maturity; capsule.

Pollen. A product of the anthers which is capable of fertilizing the stigma. It is usually granular and powdery.

Pollination. The conveyance of pollen from the anther to the stigma.

Polygamous. Said of plants or species which bear both perfect and imperfect flowers.

Pome. A fleshy fruit with a papery core surrounded by a greatly thickened calyx, as the apple, quince, etc.

Race. A fixed variety; that is, a variety which reproduces itself more or less uniformly from seeds.

Raceme. A more or less elongated and simple flower-cluster with one-flowered pedicels.

Regermination. Second germination. Seeds which have been checked after germination has begun may resume the process under favorable conditions.

Root. A part of the plant which bears neither leaves nor buds, and which absorbs nourishment for the plant, or serves as a support for it. It may be subterranean or aërial. 
Root-cap. The covering upon the end of a growing root. The elongation of the root takes place just behind the root-cap.

Root-grafting. Grafting upon the root.

Root-hair. A very delicate prolongation of a cell of a young root. Root-hairs are active agents in absorbing plant-food.

Rot. The decay of the thicker part of plants, however brought about; the amount of moisture present determining whether it shall be called wet or dry rot, as potato-rot.

Ranner. $\Lambda$ procumbent or creeping herbaceous shoot which takes root at the joints.

Rust. Any plant-disease in which the surface of the plant is apparently converted into a powder or scurf, particularly when of a ferruginous or blackish color, as wheat-rust.

Saddle-graft. A sort of grafting in which the scion is split below and inserted over the end of the stock, which is cut wedge-shape.

Salad. A dish of uncooked herbs, or chopped meat combined with uncooked herbs.

Sap. A term designating loosely the liquid contents of plants.

Saprophyte. A plant which lives upon dead or decaying matter, as a mushroom or toadstool.

Scion, or Cion. $\Lambda$ portion of a plant which is mechanically inserted upon the same or another plant with the intention that it shall frow; a graft. As commonly used, a scion, in distinction from a bud, bears two or more buds.

Secondary hybrid. A hybrid between hybrids, or between a hybrid and one of its parents; derivative hybrid; derivation-hybrid.

Se'pal, or Sep'al. One of the separate parts of the calyx; an outer leaf of a flower.

Shoot. A soft and growing branch.

Shrub. A small and bushy woody plant, with no central stem or trunk; a bush.

Side-graft. A sort of grafting in which the scion is inserted in a slit or oblique cleft in the side of the stock.

slip. A cutting.

Small-fruit. Low and bush-like fruit-plants, and the fruits they produce, as the currant, gooseberry, blackberry, strawberry, and the like.

Splice-graft. A sort of grafting in which both the scion and stock are cut off obliquely and the cut surfaces applied to each other, the two scions being held secure by bands of string. 
Seed. The sexual reproductive organ of flowering plants; a ripened ovule. Its essential part is the embryo, or rudimentary plantlet.

Seedage. The process of propagation by seeds, or the state or condition of being propagated by seeds.

Seed-germ. The rudimentary plant contained in the seed; embryo.

Seedling. A plant growing directly from the sced, without the intervention of grafts or cuttings.

Self-fertilization. The action of pollen upon a pistil of the same flower; close-fertilization.

Self-pollination. The transfer of pollen to a pistil of the same flower.

Spore. The reproductive body of a flowerless plant, answering to the seed of a flowering plant. It contains no embryo.

spur. A very short and small branch bearing leaves or flowers.

Stalk. In descriptions of apples and similar fruits, the stem or pedicel.

Stanen. That portion of the flower which bears the pollen. It consists of the anther and filament. It is the male organ of the plant.

Staminate. Bearing stamens alone; male.

stem. That portion of the plant which bears leaves or buds, or both. It may be aërial or subterranean.

stigma. The upper extremity of the pistil upon which the pollen is received. It is usually more or less pappilose and glutinous.

Stipule. A more or less leaf-like and usually small appendage at the base of a petiole. Stipules are borne in pairs, but they are not always present.

Stock. 1. The parentage of a particular strain or variety. 2. A plant or part of a plant upon which a bud or graft is set.

Stolon. A decumbent shoot which roots at or near the tip, as the shoots of black raspberries.

Stove. A very warm glass house, used for growing tropical plants.

Strain. A subvariety, or individuals of a variety, which has been improved and bred under known conditions.

Stub. A portion of a trunk or branch which has been recently grafted. Usually applied to top-grafting.

Style. The more or less slender portion of the pistil connecting the stigma and ovary. 
Tongue-graft. Whip-graft.

Top-grafting. Grafting upon the top of a plant.

Tree. A woody plant attaining the height of a man or more, and having a definite central stem or trunk.

Trass. Loosely applied to clusters of flowers or fruits.

Tuber. A prominently thickened root or stem, usually subterranean.

Umbel. A flower-cluster which is flat or flattish on top, and whose pedicels start from a common point, or nearly so.

Variety-hybrid. A cross between varieties of the same species; half-breed; cross-breed; mongrel.

Vegetable. 1. A plant. 2. In horticulture, an edible portion of an annual plant; kitchen-garden vegetable. In the latter sense a loose term.

Vegetable-gardening. The cultivation of kitchen-garden vegetables; olericulture.

Vegetation. 1. Vegetable or plant-life. 2. The process or act of vegetating or growing.

Veneer-graft. $\Lambda$ sort of grafting in which the scion is applied to the side of the stock, only the bark being removed between them.

Viticultare, Grape-culture.

Weed. A plant which grows where it is not wanted and which becomes troublesome.

Whip-graft. A species of grafting in which the scion is secured to the stock by means of a tongue which is inserted in a cleft in the stock; tongue-graft.

wilding. A wild or uncultivated plant. Commonly used to designate the wild individuals of a cultivated species.

Wind-shake. An injury to the trunk of a tree, consisting of the more or less complete separation of the concentric annual layers or of the separation of the bark from the wood. The injury is commonly ascribed to the wind, but it is oftener due to the frost and other causes.

Winter-killing. The process or act by which a plant is killed by the climate of winter.

Worm. A term properly applied to a large class of legless artic. ulated animals, of which the angleworm, or earthworm, and trichina, are examples. The term is commonly, but improperly, applied to the larvæ of insects. 


\section{INDEX.}

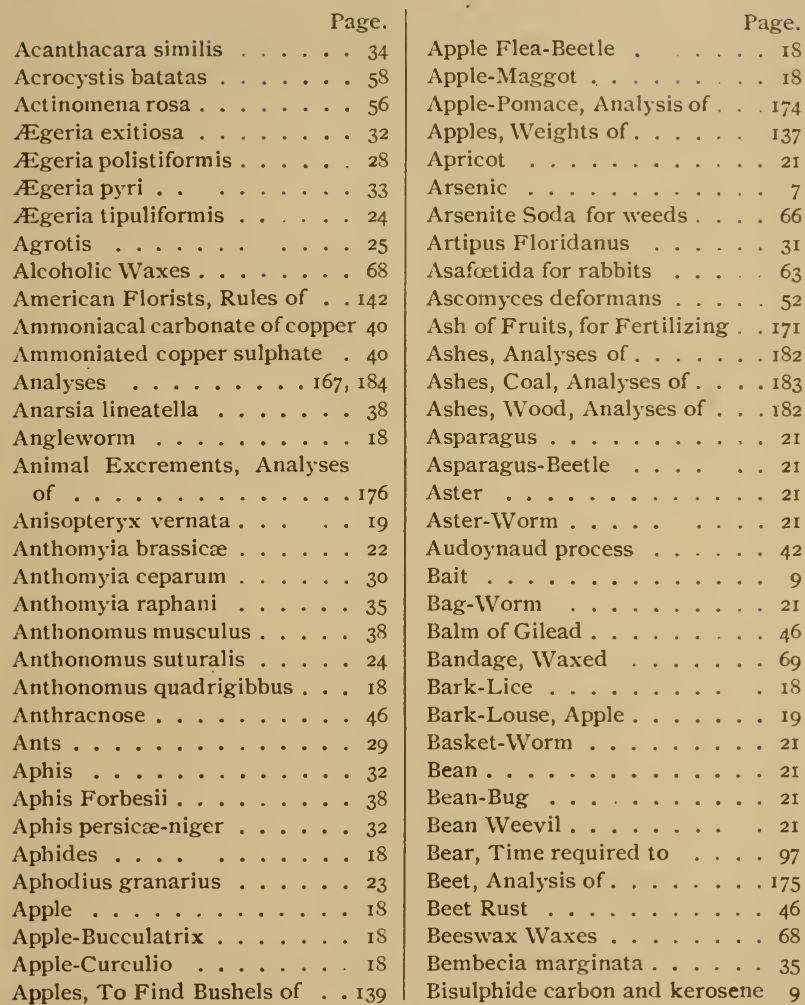




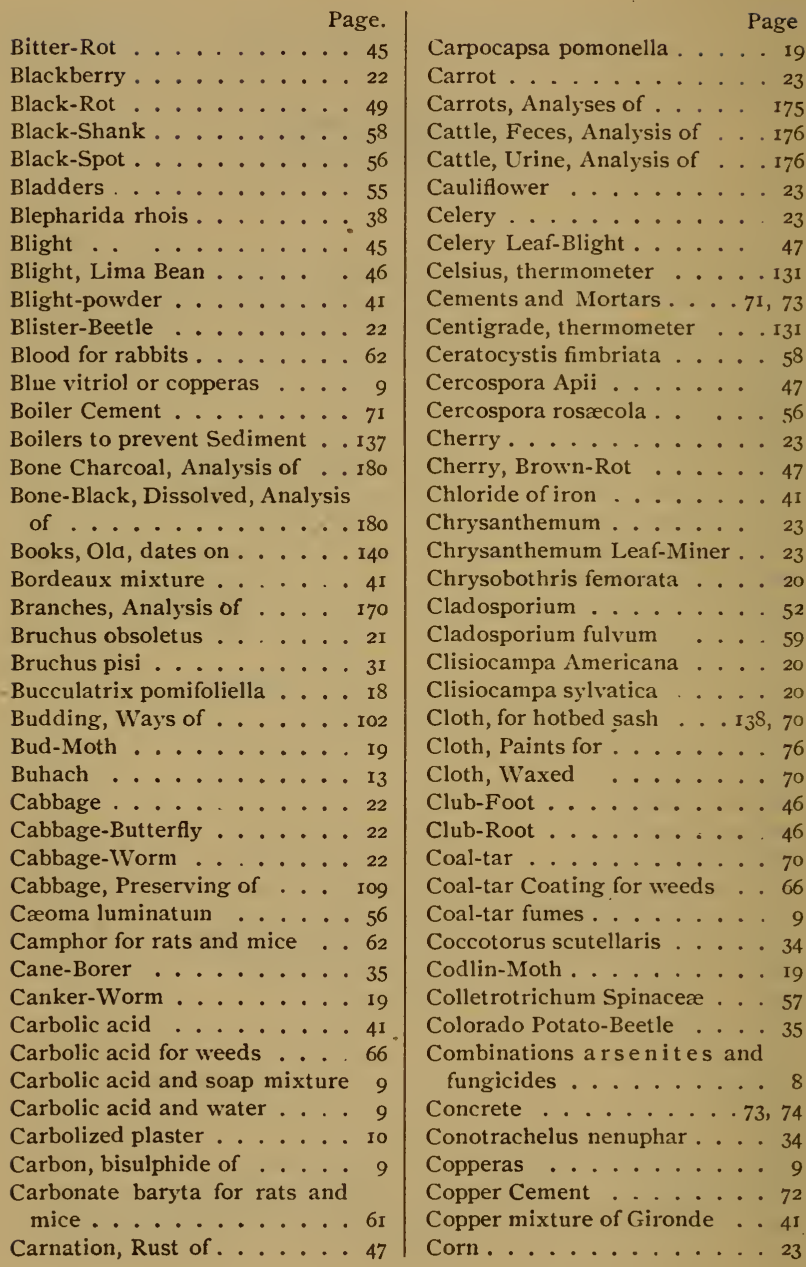




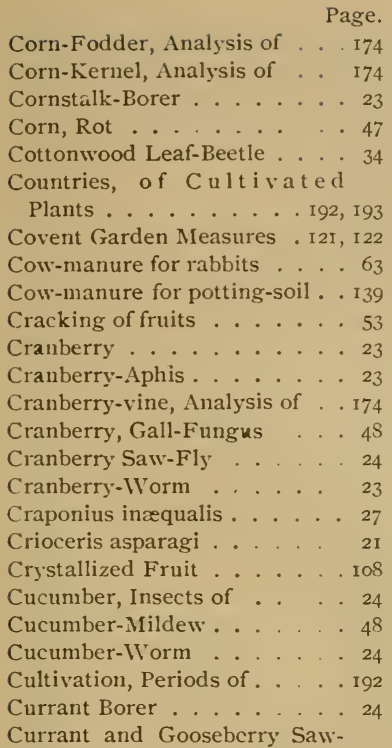

Fly .......... 4

Currant Measuring-Worm . . . 25

Currant Rust . . . . . . 48

Currant-Worm . . . . . 24 24

Cupric steatite. . . . . 43

Curculio . . . . . . . . 34

Cut-Worm . . . . . . . . 25

Cut-Worm, Climbing . . . . 25

Cystopus Ipomœa-panduranæ . 59

Dactylopus adonidum . . . . 30

Dahlia . . . . . . . . 26

Dakruma convolutella . . . . 27

Dalmation insect-powder . . . 13

Damping-off . . . . . 4 48

Darapsa myron . . $\quad \ldots 28$

Dates, for Sowing and Setting $\delta 7,89$

Dates of Fruits and Nuts . . I I34

David's powder . . . . . 42
Page.

Depressaria heracliana . . . . 31

Derivation, of Names . . . . Igo

Destroying affected parts .. 42

Deutzia ......... 26

Diabrotica I2-punctata . . . 24

Diabrotica vittata . . . . . 24

Diplosis pyrivora . . . . 33

Doryphora decemlineata . . . 35

Downy Mildew . . . . . . 50

Dove-Manure . . . . . . 179

Dried Blood, Analysis of . . . 181

Dry Ground Fish, Analysis of . I8I

Dry Matter, Composition of . . I70

Dry-Rot . . . . . . 58

Dung, Cow, for potting-soil . . 139

Duck-Manure . . . . . . 179

Earthenware Cement . . . 72

Earthworm ........ Is

Eau celeste . . . . . . 42

Eau Grison . . . . . 42

Edioptis nitidalis . . . . . 24

Egg-Plant . . . . . . 26

Elaphidion parallelum .... 2I

Elaphidion villosum . . . . 21

Elements, Symbols of . . . . 167

Elm ........... . . 26

Elm Flea-Beetle . . . . . . 26

Emphytus maculatus . . . . 38

Empoa albopicta . . . . . . . 25

Endive .......... 26

Entomosporium maculatum . . 53

Entomosporium maculatum var.

Cydoniæ . . . . . . . . 56

Entyloma Ellisii . . . . . . 57

Erythroneura vitis . . . . . 28

Esteve process . . . . . . 43

Eudemis botrana . . . . . 27

Eudioptis hyalinata . . . . 30

Eufitchia ........ 25

Exoascus derformans .... 52

Fahrenheit, thermometer . . I3I

Fall Wèb-Worm . . . . . . . I9

Fertilizers, Analysis of . . 179

Fertilizers, Value of, $1891 \ldots 183$ 
Fidia viticida . . . . . . $\begin{array}{r}\text { Page. } \\ 27\end{array}$

Figures and Statistics . . I39, I40

Fire-IVorm ........ 23

Fireproof or Stone Cement . . 72

Fiat-Headed Borer . . . . . 20

Flea-Beetle ........ . 26

Flower-Pots, to keep clean . . I 137

Plower-Pots, Standard . . . . . II3

Flowers, National and Party . . I33

Flowers, Preserving and Print-

ing ........ I I59, I64

Four-Striped Plant-Bug . . . 25

Formica ........ 29

Frenching ....... 52

French Waxes........ 69

Fruits, Analyses of . . . . . I68

Fruit and Branches, Analyses of 171

Fruits and Nuts, Dates of . . . I34

Fruits, in Various Languages .

Fruits, how Multiplied . . . . . I02

Fruit Plants, Analyses of . . . . 168

Fire-Proof Paint . . . . . 75

Fruits, Sub-Tropical, Analyses

of ............ I69

Fruit-lVorm ....... . 38

Fusicladium dentriticum . . 46

Fusicladium pyrinum . . . . 53

Galleruca xantho-melœena . . . 26

Garden Borders, Concrete for . 73

Garden Seeds, Longevity of . . 83

Garden Seeds, Time required to germinate ........ 86

Garden Seeds, IVeight and Size .. ....... 79

Garden Vegetables, Naming of . 142

Gas-Lime, Analysis of . . . . . 183

Goose-Manure . . . . . . I78

German Potash Salts, Analysis of ........... 182

Gipsy-Moth ...... . 26

Girdling by mice . . . . . . 6 6 I

Glæosporium fructigenum . . . 5 I

Glæosporium Lindemuthianum 46

Glæosporium necator ... $5^{6}$
Page.

Glæosporium nervisequum . . 54

Glass bottles, Cutting . . . . . I37

Glass, Cement for . . . . 72

Glass for Commercial Purposes . 132

Glass, Reflection from . . . . 132

Glossary . . . . . . . 200

Glues ........ 76, 77

Glue and arsenites wash .... Io

Gooseberry ........ 27

Gooseberry Fruit-Worm . . . 27

Gooseberry-Mildew . . . . $4^{8}$

Grafting, Ways of . . . . IOI

Grain-Aphodius ...... 23

Grape ......... . 27

Grape, Anthracnose . . . . 49

Grape-Berry Worm ..... 27

Grape-Curculio . . . . . 27

Grapes, Keeping . . . . . . 106

Grape Seed-Worm . . . . . 27

Grape-Slug ...... 27

Grape-rine Fidia . . . . 27

Grape-rine Flea-Beetle . . . 27

Grape-vine Root-Borer . . . . . 28

Grape-rine Sphinx . . . . 28

Graptodera chalybea . . . . 27

Graptodera foliacea ..... I8

Grasshoppers . . . . . 29

Greenhouse-Roofs, Paint for . . 75

Green-Fly . . . . . . . 29

Green Leaf-Hopper . . . . . 25

Green Lettuce-WWorm . . . . . 29

Grison liquid ...... 42

Ground Bones, Analysis of . . 180

Ground-squirrel, remedies . . . 63

Gryllotolpa borealis . . . . 35

Gum, Flower . . . . . . 77

Gypsum, Analysis of ... I82

Haltica striolata . . . . . 26

Harlequin Cabbage-Bug . . . 22

Hay, Tons in a Mow . . . . . 139

Hay, Tons in a Stack ... I I39

Heliothis armigera ... 38

Hellebore, White ..... 17

Helotropha atra ...... 23 


\begin{tabular}{|c|c|c|c|}
\hline & & $\begin{array}{r}\text { Page. } \\
\text {. } 178\end{array}$ & Leaf-Hopper . . . . \\
\hline arium, To make & . & . . $15^{8}$ & Leaf-Mold . . . . . \\
\hline erodera radicicola & . . & . . 36 & Leaf-Notcher . . . \\
\hline ilgar's Wash . . . . & . . & . . 43 & Leaf-Rust . . . . . \\
\hline ollyhock . . . . & . & . . 29 & Leaf-Scorching . . . . 54 \\
\hline lollyhock Rust . . . & . . & . $5^{1}$ & Leaf-Spot . . . . . . 56 \\
\hline Horse-Feces . . . . & . . . & . 177 & Legal Sizes . . . . . . II6 \\
\hline Horse-Urine . . . . . & . . & .177 & 1 lVeights . . . . . II6 \\
\hline Hoskin's Wax. . . . & & . . 70 & tuce ............29 \\
\hline Hot water . . . . . & . . & . . 10 & Lettuce-Mildew . . . . \\
\hline Human Feces .... & . . & .178 & Spray ....... \\
\hline n Urine . . . . & . . & . 178 & , sulphur for weeds. . \\
\hline Hyphantria textor. . & . . . & . . 19 & Lina scripta $\ldots \ldots . . .34$ \\
\hline , Collecting and & & & 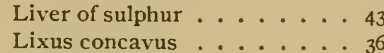 \\
\hline ron cement $\ldots$ & $\begin{array}{l}\cdots \\
\cdots\end{array}$ & . 71 & London purple . . . . . . \\
\hline na vitis .... & . . & . . 27 & London purple lye and sulphur \\
\hline Sumac-Beetle & & . $3^{8}$ & wash .......... II \\
\hline , Analyses of & . . & . . 182 & vity of fruit-trees . . . 98 \\
\hline Katydid ... . . & & . . 32 & Loudon's Rules of Horticulture $14 x$ \\
\hline Keeping Apples ... & & . . 104 & Louse ......... 23 \\
\hline Keeping Figs . . . . & & . . 105 & Lye and whale-oil soap wash . . \\
\hline ruits and $\mathrm{Ve}$ & & bles I04 & Lytta ........ 22 \\
\hline seberries & & . . 105 & Macrodactylus subspinosus . . 37 \\
\hline Keeping Grapes for Ma & arket & . . 106 & Macrosila quinquemaculata . . $3^{8}$ \\
\hline Keeping Pears ... & . . & . . 104 & Macrosporium tomato . . . 59 \\
\hline Kerosene .... & $\cdots$ & .. 10 & Maggot ........ 35 \\
\hline $\begin{array}{l}\text { Kerosene and condens } \\
\text { emulsion . . . . }\end{array}$ & sed & milk & $\begin{array}{l}\text { Mail Matter, Rates of . I50, } 152 \\
\text { Manure, Analyses of . . . I76 }\end{array}$ \\
\hline sene and milk emu & ulsion & n. . 10 & Maple Leaf-Spot . . . . . 5 \\
\hline ne and water em & nulsio & on . II & Margarodes quadristigmalis . . 35 \\
\hline mulsion & & . . 10 & Maturity, Time required for . . 97 \\
\hline Seeds & for . & . . 86 & May-Bug $\ldots \ldots \ldots$ \\
\hline cimens, & Gum & for 77 & May-Beetle ....... . 30 \\
\hline for .... & . . & . 137 & Mealy Bug ........ 30 \\
\hline preserve & 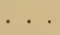 & . $13^{8}$ & Measures .........113,128 \\
\hline na fusca. & & . . 30 & Measures, Value of $\ldots$. I39 \\
\hline dia Bidwelli . . & & . . 4 & Melampsora populina $\ldots . .55$ \\
\hline and-Plaster, Analysis & & . . 182 & $\ldots \ldots \ldots$ \\
\hline & . & . 29 & -Worm ..... 30 \\
\hline Lea & & . . $5^{8}$ & Metals, To keep from rusting .76 \\
\hline & & & Measure . . . 127, 128 \\
\hline Leaf-Crumpler . . . & & . . 29 & Mice girdling trees $\ldots \ldots \mathrm{r}$ \\
\hline Leaf-Brownness .... & $\cdots$ & . 56 & Mice, Injuries by . . . . 62 \\
\hline
\end{tabular}


Microcentrum retinervis . . . 30 Micrococcus amylovorus . . . 53 Midge . . . . . . . . 33 Mite ........... . 31 Mole-Cricket . . . . . . 35 Monilia fructigena . . . . . 47 Monilochætes infuscans . . . $5^{8}$ Mortar ... . . . . . 73 Morthiera Mespili . . . . . 53 Moss on Lawns . . . . . . . 67 Moss on Trees . . . . . . 67 Moss on Walks ...... 67 Mushroom . . . . . . . . . 30 Mushroom-Fly ...... 30 Muriate of Potash, Analysis of . 182 Mytilaspis pomorun . . . . . 19 Myxus persicæ . . . . . . . 32 Names of Fruits, Derivation . . 190 Names of Vegetables, Derivation . . . . . . . 190, 191 Nematus ventricosus . . . 24 Nitrate of Soda, Analysis of . . I8I Nomenclature, Rules of . . . I4I Oak-Leaves, Analysis of . . . 179 Oberea bimaculata . . . . . 3 35 Ocneria dispar . . . . . . . 26 Ecanthus niveus $\ldots \ldots .36$ Oidium erysiphoides . . . . . 59 Oidium erysiphoides var. Curcurbitarum ....... 48 Oil and alkali wash ..... I2 Old Books, Dates of . . . . . 140 Oil Vitriol for weeds . . . . . . 66 Oncideres cingulatus . . . . 34 Onion ........... 30 Onions, Preserving . . . . r ro Onion-Rust $\ldots \ldots \ldots 5^{\text {I }}$ Orange .......... 30 Orange-Leaf Scab . . . . . $5^{2}$ Orange-keeping ...... $5^{6}$ Orange-Rust . . . . . . . . 56 Orgya leucostigma ...... 2I Orthotylus delicatus . . . . . 29 Oscinis .......... 23
Page.

Paints....... . . 73, 76 Paper, for hotbed sash . . . 138 Paper, Paints for . . . . . 76 Paper, Waterproof. . . . . ${ }_{138} 8$ Papilio Asterias . . . . . 31 Paraffine oil ....... 12 Paris green ....... 7 Parsley-Worm ...... . 3r Parsnip Web-Worm .... . 3r Paste, French, for rats and mice 62 Pea-Bug ....... 3 I Pea-IVeevil ....... 3I Pea-Straw, Analysis of . . . 174 Peach, Analyses of . . . . . 170 Peach, Curl . . . . . . 52 Persian insect-powder .... I3 Peach-Louse . . . . . . . 32 Peach-Tree Borer . . . . . . 32 Peach-Twig Moth . . . . . 32 Pear-Blight ....... . 53 Pear-Leaf Blister . . . . . 33 Pear-Tree Borer . . . . . . 33 Pear Twig-Beetle . . . . . 20 Peas, Analysis of . . . . . . . 175 Perfumery, To make . . . . . . 164 Peronospora effusa . . . . . 57 Peronospora gangliformis . . . 5 I Peronospora Schleideniana . . 5I Peronospora Violæ ..... 60 Peronospora viticola . . . . 50 Persimmon ....... 34 Peruvian guano ...... 179 Phenic acid ...... $4^{\mathrm{I}}$ Phoma batatæ . . . . . 58 Phoma uvicola. . . . . . 49 Phopobota vacciniana ... 23 Phoxopteris comptana . . . 37 Phragmidium mucronatum . . 57 Phycis indigenella ..... 29 Phyllosticta acericola .. . 5 $5^{\mathrm{I}}$ Phyllosticta bataticola . . . . $5^{8}$ Phyllosticta Chenopodii . . . 57 Phyllotreta vittata ..... 26 Phylloxera vastatrix ..... 28 
Page.

Phytophthora infestans . . . 55

Phytophthora Phaseoli . . . . 46

Phytoptus pyri . . . . . 33

Pickle-Worm . . . . . . 24

Pieris rapæ ....... 22

Pineapple ........ 34

Pipes, Water held by . . . . 129

Pitch Waxes........ 69

Pits and Frames, Paints for . . 76

Plane-Tree ....... 54

Plant-Lice .... ... I8

Planting Fruits, Distance . . . 90

Planting Vegetables, Distance . 9I

Plants, Collecting . . . . 158, 159

Plants, Preserving . . . . 158, 159

Plants, Preserving and Printing . . . . . . . . 59, 164

Plants to Set an Acre . . . .92, 96

Plasmidiophora brassicæe . . 46

Plaster and kerosene . . . . . . 12

Plowrightia morbosa ... . 54

Plum ......... . 34

Plum-Curculio . . . . . . 32

Plum-Gouger . . . . . . 34

Plum-Knot . . . . . . . 54

Plum Leaf-Rust . . . . . . 54

Plum Pockets . . . . . . . 55

Plum-Wart ...... . 54

Plusia brassicæ .. . . . . 29

Pod-Rust ......... . 46

Podeschard's powder . . . . 42

Podospæra oxycanthæ . . . 45

Poecil ocapsus lineatus . . . . 25

Poison, California rabbit . . . . 63

Polyporus versicolor . . . . . 53

Poplar, Disease of . . . . . 55

Postage, Foreign ...... ${ }_{552}$

Potash . . . . . . . . . I2

Potassium sulphate . . . . 43

Potatoes, to find bushels in bin 139

Potato-Rot . . . . . . . . 55

Powdery Mildew . . . . . . . 50

Precipitated carbonate of Copper
Preserving Fruits for Exhibition ........ . ro8

Prim, Insect of . . . . . . 35

Pristiphora identidem . . . . 24

Privet Web-Worm . . . . . 35

Promoting growth . . . . . . 12

Propagating, Ways of . . . I00

Psylla pyri . . . . . . 33

Puccinia Malvacearum . . . . $5^{1}$

Puccinia pruni-spinosæ . . . 54

Putty, for Glazing . . . . . 138

Pyrethrum . . . . . . . I2

Pyrethrum cinerariæfolium . . 13

Pyrethrum roseum . . . . 13

Quassia ........ I4

Quince, Insects of . . . . 35

Quince-Blight ...... 56

Rabbits, Injuries by . . . 62,63

Radish, Insects of . . . . 35

Raspberry, Insects of . . . 35

Raspberry, Analyses of . . . ${ }^{170}$

Raspberry Cane-Rust . . . 56

Raspberry Root-Borer . . . . 35

Raspberry Saw-Fly . . . . 35

Reaumur, thermometer . . . I3I

Recipes and Rules . . . . . . 137

Red-Legged Flea-Beetle . . . . 32

Red-Rust of Raspberry . . . . . 56

Red-Spider . . . . . . . 36

Resin and fish-oil soap . . . . . I4

Resin and petroleum soap . . . 14

Resin soap . . . . . . . 14

Resin, soda and tallow soap . . 14

Resin wax ........ . 68

Rhizopus nigricans . . . 58

Rhodites radicum . . . . . 36

Rhubarb-Curculio . . . . 36

Ripe-Rot of Peach . . . . . 5 I

Rœestelia ..... . . 45

Root Gall-Fly . . . . . . 36

Root-Knot . . . . . . 36

Root-Louse ..... . . 20

Roots, Preserving of . . . . . 110

Root-Rot of Pear . . . . . . 53 


\begin{tabular}{|c|c|c|}
\hline & & \\
\hline ose-beetle ....... 37 & Snails ....... & . . \\
\hline ose-bug $\ldots \ldots 37$ & Soap and arsenites ... & 15 \\
\hline$\ldots \ldots 37$ & oap and lime wash . & . . 15 \\
\hline ose, Leaf-blight $\ldots \ldots$ & Soap and soda wash . . & .. 15 \\
\hline ose Leaf-hopper . . . . . 37 & Soap and tobacco ... & .. 15 \\
\hline ot and Blight of Peach . . . $5^{2}$ & & \\
\hline ound-headed Borer . . . . . 20 & Society standard measures & \\
\hline ules .......... I41, 150 & Soda and aloes .... & . . . I \\
\hline $\begin{array}{l}\text { ules for Awarding C o m mit- } \\
\text { tees ............. } 443\end{array}$ & $\begin{array}{l}\text { Soda and resin wash. . . } \\
\text { Soda and whale-oil soap }\end{array}$ & \\
\hline for Exhibitors . . . . 143 & & 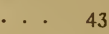 \\
\hline es for Exhibition $\ldots$ I45 & 1..... & . . I \\
\hline s of Horticulture . . . . I41 & sweet-potato & . . 5 \\
\hline ules of Mass. Hort. Society . I44 & sweet-potato & \\
\hline ules of Mich. Hort. Society & $\mathrm{m} \ldots \ldots$ & . 25 \\
\hline$\ldots \ldots \mathrm{I}_{45}, \mathrm{I} 50$ & elinum & \\
\hline Nomenclature . . . I4I & æ . & \\
\hline To prevent $\ldots \ldots$ & tagnei & \\
\hline lime wash ..... 15 & nosa. & . 5 \\
\hline weeds ..... 66 & -uvæ & \\
\hline candida .... 20 & of. . & . . 57 \\
\hline a cretata ..... 20 & ving . . & . . 110 \\
\hline fy .......... 27 & potato & \\
\hline$\ldots \ldots \ldots$ & estina. . . & . 3 \\
\hline & Fruits ... & . I IC \\
\hline Thermometer .... I3I & & . . 10 \\
\hline rus ebenus . . . $3^{8}$ & aica . . . & . . 22 \\
\hline ura lanigera .... 20 & ts of. & \\
\hline ..... 72 & ses of. & . . 170 \\
\hline lysis of . . . 179 & borer & . 37 \\
\hline re .... $7^{8}$ & light. & . 57 \\
\hline erasi ...... 23 & roller & . . 37 \\
\hline rubi ......... 35 & ry-mildew .. & . . 57 \\
\hline 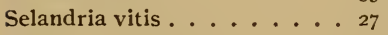 & -borer & \\
\hline rasina .... 54 & ry Root-louse & . . $3^{8}$ \\
\hline Dianthi . . . . . 47 & erry Saw-fly & \\
\hline Ribi ...... $4^{8} 8$ & Vaxed .... & \\
\hline ces ........ . . & ite .... & \\
\hline 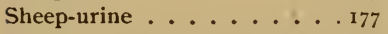 & AmmoniaAualy & lysis of 18 \\
\hline to find bushels of 135 & of copper. . . & \\
\hline le fungus, Plum . . . 5 & e of iron .... & \\
\hline ....... & phate of Magnesia, Ar & nalysis \\
\hline$\ldots \ldots$ & lphate of Potash, Analy & \\
\hline
\end{tabular}


Page.

Sulphated sulphur . . . . . $4^{1}$

Sulphatine . . . . . . 43

Sulphide of soda wash . . . . I6

Sulphur ......... I6 6

Sulphur and lime ..... 44

Sulphur and snuff . . . . . 16

Sulphur and whale-oil soap wash ........ I6

Sulphur for rabbits .... 63

Sulphuret of potassium ... 43

Sumac, Insect of ...... 38

Sweet-potato, Insects of . . . 38

Sweet-potato, Black-rot . . . $5^{8}$

Sweet-potatoes, preserving . . IIo

Swine-feces ........ . I77

Swine-urine . . . . . I78

Symbols, Chemical . . . . 197

Synchytrium vaccinii .... 48

Tanks and IVells, Capacities of I26

Taphrina deformans.... 52

Taphrina pruni ..... 55

Tar Cement ....... 72

Tartar emetic for rats and mice 6I

Tent-Caterpillars ..... 20

Termites ....... 39

Tetranychus bimaculatis .. 30

Tetranychus 6-maculatus .. . 3I

Tetranychus telarius ..... 36

Tettigonia rosæ ..... 37

Thyridoptery $x$ ephemeræformis $2 \mathrm{I}$

Thrip ......... 28

Title-pages, Dates on ... I40

Tmetocera ocellana ..... I9

Tobacco ......... I7

Tomato, Insects of . . . 38

Tomato-blight . . . . . 59

Tomatoes, Preserving .... . II2

Tomato-ringer . . . . . 38

Tobacco-stenis, Analyses of . . ISo

Tomato-worm ..... 38

Tree-cricket ...... 36

Tree seeds, Number, in pound 82

Trichobaris t:inotata . . 35

Trypeta pomonella .... Is
Page.

Turuip, Insect of . . . . . . 39

Turuip, Analysis of . . . . I75

Tussock-moth . . . . . . 2I

Twig-girdler ...... 34

Twig-pruners . . . . . 2I

Tyloderma fragariæ... . 37

Typlocyba albopicta . . . . 25

Uncinula spiralis ..... 50

Unmailable matter . . . . I52, I54

Urocyst is cepulæ . . . . . 5I

Uromyces betæ ...... 46

Uromyces caryophyllinus . . 47

Ustilago Zeæ-Mays . . . . 47

Vegetables, Hardy . . . . 90

Vegetables, Names in various

languages ........ . I86

Vegetable Kingdom, Statistics

of ........... . I94

Vegetables, Names in America

and England ...... I $8_{5}$

Vegetables, Tender .....99

Venessa antiopa ...... 39

Verbena-rust ..... 59

Violet disease or rust . . . . 60

Wash for mice. . . . . . . 62

Wash for sheep injury . . . . 62

Wash to keep rabbits from trees 62

Watermelon pod-rust .... 60

Waxes ...... 68, 69, 70

Veeds ....... 65, 66

Weigelia, Insects of . . . 39

Whale-oil soap ...... I7

White ants ...... 39

White hellebore ...... I7

Wholesale quantities ... . I35

Willow, Insects of . . . . 39

Wind, cooling glass . . . . . I3I

Wire-worm ........ . 39

Wounds, Waxes for . . . . 70

Xyleborus pyri .. . . . 33

Yellows ........ . 52

Yields, per acre . . . . 9 98, 99

Zinc labels, Ink for . . . . I I37 


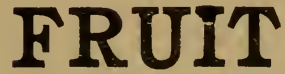

and ORNAMENTAL

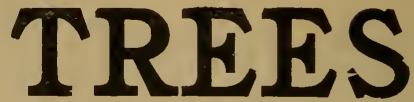

Shrubs, Grapes, Hardy

\section{Plants, Paeonies, Small Fruits.}

\section{ELLWANGER \& BARRY,}

Mount hope Nurseries, Rochester, N. Y.

New IIIustrated and descriptive priced General Catalogue, containing information indispensable to planters - the most complete published, Free.

\section{THE BEST BOOKS.}

ANNALS OF HORTICULTURE FOR 1891.- "Bright, new, clean and fresh" may be said of this series, by L.H. BAILEY. Each year's experience makes the succeeding volum:e a better one. The list of introductions for each year is unique. It puts on record every novelty of fruit, flower, vegetable and tree of the year. All the tools of the year are described and illustrated, whether for use in orchard, garden or greenhouse. Every advance in American horticulture is chronicled. The volumes are a storehouse of information to every one who grows flowers, fruits, vegetables or trees. It describes the new insects and fungous depredations. The obituaries of the year are included. The volume for 1891 contains a census of native cultivated plants, being a carefulfy annotated and dated list of all the plants in cultivation of American origin, including hundreds of entries. This is one of the boldest pieces of work yet attempted in American horticulture. The volume for $189 \mathrm{r}$ also contains a history and statistical record of the Farmers' institute movement in the United States and Canada. The work of the Experiment Stations is exhaustively discussed and indexed.

Price, cloth, $\$ 1$; paper, 60 cents. Annals for 1889 and 1890 at the same price. 
|NSECTS AND INSECTICIDES.-A practical Manual concerning ious Insects and the Methods of Preventing their Injuries. By Clarence M. Weed, Professor of Entomology and Zoology. New Hampshire State College.

I think that you have gotten together a very useful and valuable little book.-Dr. C. V. RiLEY, U. S. Entomologist.

It is excellent. I must congratulate you on the skill you have displayed in putting in the most important insects, and the complete manner in which you have done the work.-JAMEs Fletcher, Dominion Entomologist.

I am well pleased with it. There is certainly a demand for just such a work.-Dr. F. M HEXAMER, Editor American Agriculturist.

Price, cloth, \$1.25.

The Cauliflower.-By A. A. Crozier. Origin and History of this increasingly important and always delicious vegetable.

The Cauliflower Industry.-In Europe. In the United States. Importation of Cauliflowers.

Management of the Crop.-Soil. Fertilizers. Planting. Cultivating. Harvesting. Keeping. Marketing.

The Early Crop.-Caution against planting it largely. Special directions. Buttoning.

Cauliflower Regions of the United States.-Upper Atlantic Coast. Lake Region. Prairie Region. Cauliflowers in the South. The Pacific Coast.

Insect and Fungous Enemies.-Flee-Beetle. Cut-Worms. CabbageMaggot. Cabbage-Worm. Stem-Rot. Damping-Off. Black-Leg.

Cauliflower-Seed.-Importance of careful selection. Where the Seed is grown. Influence of Climate American-grown Seed.

Varieties.-Descriptive Catalogue. Order of Earliness. Variety tests. Best Varieties.

Broccoli.-Difference between Broccoli and Cauliflower. Cultivation, use and varieties of Broccoli.

Cooking Cauliflower.-Digestibility. Nutritive Value. Chemical Composition. Receipts.

Price, Cloth, \$r.

DRACTICAL FARM CHEMISTRY.-A Practical Handbook of Profitable Crop Feeding written for Practical Men. By T. Greiner.

Part I. The Raw Materials of Plant-Food.

Part II. The Available Sources of Supply.

Part III. Principles of Economic Application, or Manuring for Money.

This work, written in plainest language, is intended to assist the farmer in the selection, purchase and application of plant-foods. If you wish to learn ways how to save money in procuring manural substances, and how 
to make money by their proper use, read this book. If you want your boy to learn the principle of crop-feeding, and become a successful farmer, give him a copy of this book. The cost of the book will be returned a hundredfold to every reader who peruses its pages with care and applies its teachings to practice.

Price, cloth, $\$$ r.

THE NEW POTATO CULTURE.-By Elbert S. CARMan. This book gives the result of 15 years' experiment work on the Rural grounds. It treats particularly of: How to increase the Crop without Corresponding Cost of Production. Manures and Fertilizers : Kinds and Methods of Application. The Soil, and How to Put It in Right Condition. Depth of Planting. How much Seed to Plant. Methods of Culture. The Rural Trench System. Varieties, etc., etc.

Nothing old or worn-out about this book. It tre ?ts of new and profitable methods; in fact, of The NEW Potato-Culture. It is respectfully submitted that these experiments at the Rural grounds have, directly and indirectly, thrown more light upon the various problems involved in successful potatoculture than any other experiments which have been carried on in America

Price, cloth, 75 cents; paper, 40 cents.

GARDEN, FLOWER. AND FIELD SEEDS, BULBS,

\title{
Horticultural Implements, Tools, etc.
}

\author{
Landreth's Illustrated Descriptive
}

CATALOGUE and RURAL REGISTER

FREE to all applicants.

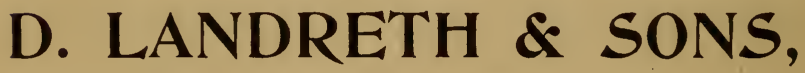

Seed and Implement Warehouse,

Nos. 21 and 23 S. Sixth St., Philadelphia, Pa. FOUNDED 1784. 



